
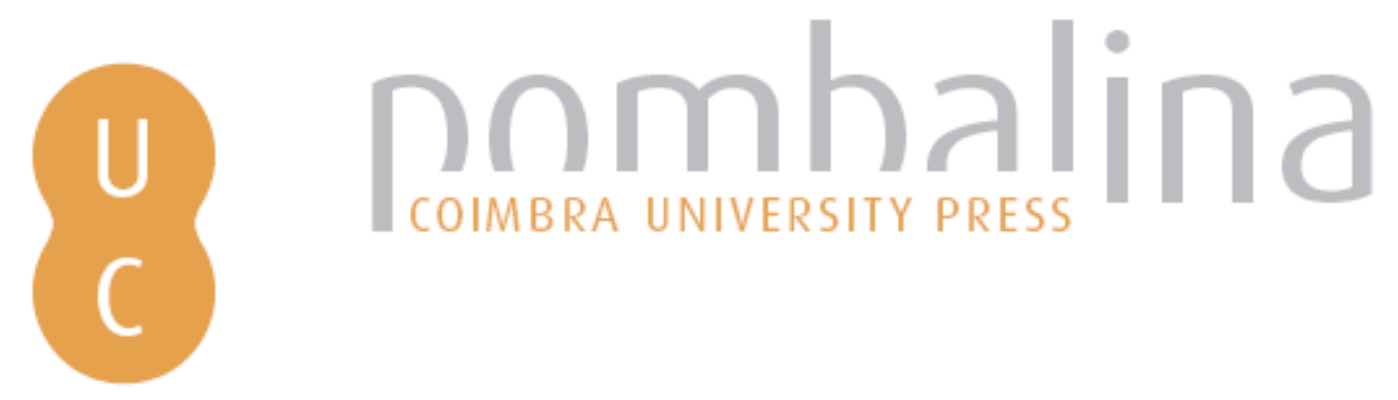

\title{
Narrativa e Media: géneros, figuras e contextos
}

Autor(es): $\quad$ Peixinho, Ana Teresa; Araújo, Bruno

Publicado por: Imprensa da Universidade de Coimbra

URL

persistente: URI:http://hdl.handle.net/10316.2/41340

DOI: $\quad$ DOI:https://doi.org/10.14195/978-989-26-1324-6

Accessed : $\quad$ 26-Apr-2023 05:05:17

A navegação consulta e descarregamento dos títulos inseridos nas Bibliotecas Digitais UC Digitalis, UC Pombalina e UC Impactum, pressupõem a aceitação plena e sem reservas dos Termos e Condições de Uso destas Bibliotecas Digitais, disponíveis em https://digitalis.uc.pt/pt-pt/termos.

Conforme exposto nos referidos Termos e Condições de Uso, o descarregamento de títulos de acesso restrito requer uma licença válida de autorização devendo o utilizador aceder ao(s) documento(s) a partir de um endereço de IP da instituição detentora da supramencionada licença.

Ao utilizador é apenas permitido o descarregamento para uso pessoal, pelo que o emprego do(s) título(s) descarregado(s) para outro fim, designadamente comercial, carece de autorização do respetivo autor ou editor da obra.

Na medida em que todas as obras da UC Digitalis se encontram protegidas pelo Código do Direito de Autor e Direitos Conexos e demais legislação aplicável, toda a cópia, parcial ou total, deste documento, nos casos em que é legalmente admitida, deverá conter ou fazer-se acompanhar por este aviso.

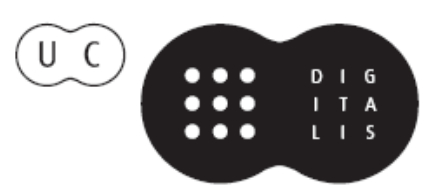



Os quinze artigos aqui reunidos aparecem organizados por forma a dar resposta a um conjunto de objetivos específicos, que presidiram à construção da obra. Por um lado, houve a preocupação de integrar o estudo dos media numa mais ampla reflexão teórica sobre narrativa, com contributos de especialistas quer das Ciências da Comunicação, quer dos Estudos Narrativos e dos Estudos Literários. Entende-se que a compreensão do funcionamento das narrativas mediáticas, objeto complexo e multímodo, exige um olhar interdisciplinar, capaz de congregar metodologias, conceitos e perspetivas de áreas disciplinares diversificadas. Por outro lado, por uma questão meramente metodológica, decidiu-se definir quatro eixos de intervenção correspondentes a quatro grandes áreas de estudo.

Assim, organizada em quatro partes, esta obra reúne contributos de investigadores e académicos de formações e áreas diversas, quer brasileiros, quer portugueses, que refletem e problematizam questões sobre a construção, a circulação e o funcionamento das narrativas no espaço mediático hodierno. 


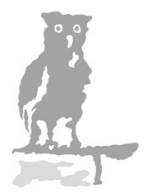

$\begin{array}{lllllllllllll}\text { I } & \mathrm{N} & \mathrm{V} & \mathrm{E} & \mathrm{S} & \mathrm{T} & \mathrm{I} & \mathrm{G} & \mathrm{A} & \mathrm{C} & \mathrm{A} & 0\end{array}$<smiles>C[C@H]1[C@H]2CC[C@@](C)(C2)[C@@H]1C</smiles> 


\section{Coordenação editorial}

Imprensa da Universidade de Coimbra

Email: imprensa@uc.pt

URL: http://www.uc.pt/imprensa_uc

Vendas online: http://livrariadaimprensa.uc.pt

$\begin{array}{ll}\text { Conceção gráfica } & \text { Comissão Científica } \\ \text { António Barros } & \text { Carlos Camponez } \\ & \text { Universidade de Coimbra } \\ \text { Infografia } & \text { Felisbela Lopes } \\ \text { Carlos Costa } & \text { Universidade do Minho } \\ \text { Execução gráfica } & \text { Fernanda Martinelli } \\ \text { Simões \& Linhares, Lda } & \text { Universidade de Brasília } \\ & \text { Monica Martinez } \\ & \text { Universidade de Sorocaba - Uniso }\end{array}$

\section{ISBN}

978-989-26-1323-9

\section{ISBN DIGITAL}

978-989-26-1324-6

\section{DOI}

https://doi.org/10.14195/978-989-26-1324-6

\section{Depósito legal}

$425158 / 17$

Obra publicada com o apoio de:

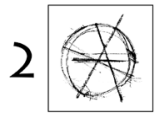

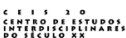

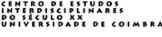

(C) ABRIL 2017, Imprensa da Universidade de Coimbra. 


\section{NARRATIVA \\ E MEDIA}

GÉNEROS, FIGURAS E CONTEXTOS

\section{ANA TERESA PEIXINHO BRUNO ARAÚJO}

EDITORES E ORGANIZADORES

IMPRENSA DA UNIVERSIDADE DE COIMBRA

COIMBRA UNIVERSITY PRESS 
(Página deixada propositadamente em branco.) 


\section{SUMÁRIO}

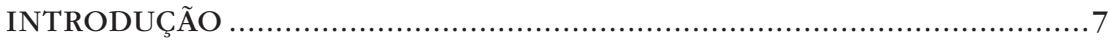

FENOMENOLOGIA DA NARRATIVA .......................................... 21

Carlos Reis, Woody Allen ou a ficção como jogo: o caso Zelig ........23

Luís G. Motta,Análise pragmática da narrativa:

teoria da narrativa como teoria da ação comunicativa

Maria Augusta Babo, Considerações sobre a máquina narrativa......71

IMPRENSA E NARRATIVA

Fernando Resende, Imprensa e conflito:

narrativas de uma geografia violentada

Bruno Araújo, Estudos narrativos e teoria do jornalismo: a narrativa de Veja e IstoÉ sobre uma manifestação de estudantes da USP.....137

Hélder Prior, Jornalismo, Narrativas e Escândalos 157

Jacinto Godinho, A minha vida não dava um filme: ensaio de desconstrução da reportagem entre a literatura e o jornalismo...183

A PERSONAGEM MEDIÁTICA

Ana Paula Arnaut, A palavra em movimento: a adaptação para cinema de "Embargo" e de A Jangada de Pedra de José Saramago...205

Ana Teresa Peixinho e Bruno Araújo, A narrativa da desconfiança na política: a figuração do político

Aletheia Patrice Rodrigues Vieira e Liziane Soares Guazina,

De herói a anti-herói: a caracterização da personagem

José Dirceu na revista Veja 
Célia Maria Ladeira Mota e Leylianne Alves Vieira,

Caminhos narrativos: um personagem: o brasileiro 289

A NARRATIVA NOS MEDIA DIGITAIS. 315

João Canavilhas et. al., Era pós-PC: a nova tessitura da narrativa jornalística na web. 317

Daniela Maduro, Entre textões e escritões: a narrativa projetada....345 Fernanda Castilho Santana, Narrativas em mudança: do folhetim aos textos transmedia .377

NOTAS BIOBIBLIOGRÁFICAS DOS/AS AUTORES/AS 409

RESUMOS/ABSTRACTS E PALAVRAS-CHAVE/KEYWORDS 417 


\section{INTRODUÇÃO}

Uma das áreas de estudo que, na última década, tem suscitado maior interesse por parte de investigadores dos media é precisamente a dos Estudos Narrativos. Sobretudo nos últimos anos, nos Estados Unidos, Bélgica, Inglaterra e Brasil, foram publicados diversos títulos sobre a narrativa mediática, em parte devido à emancipação do estudo da narrativa em relação às fronteiras dos estudos literários, mas sobretudo devido à perceção de que, na última década, os media assistiram a uma mudança muito profunda no seu funcionamento devido ao desenvolvimento da WEB 2.0 (Canavilhas, 2014; Lits, 2015).

Desde sempre, o campo dos media foi dominado, em termos textuais e discursivos pela narrativa, facto a que não é alheia a matriz representacional dos media de informação. Bastará recordar que o jornalismo, quando passa da condição de ofício para a de nova profissão, na transição do século XIX para o século XX, optou precisamente por se autodefinir como ramo de representação objetivada da realidade, criando, inclusive, para o efeito, superestruturas narrativas muito próprias e codificadas, acompanhadas de regras retóricas relativamente restritas e estabilizadas.

Por outro lado, se olharmos para os media que sucederam ao jornal impresso, como a rádio, o cinema, a televisão e para a influência que a Web, mais recentemente, exerceu sobre eles, percebe-se que, mesmo fora dos formatos noticiosos, o investimento em conteúdos de cariz narrativo foi sempre dominante: desde os folhetins radiofónicos, às radionovelas, passando pelos filmes, 
primeiro mudos e depois sonoros, até às abordagens mais sofisticadas dos formatos televisivos ou à construção da publicidade. Também no âmbito da comunicação política, da comunicação publicitária ou da comunicação organizacional, a narrativa adquiriu, nas últimas décadas, um espaço considerável enquanto estratégia discursiva, quer como procedimento de institucionalização do sentido (Figueira, 2014), quer como instrumento de persuasão ou manipulação.

Esta evolução, aqui forçosamente sumariada, permite perceber que cada novo medium inventado foi sendo utilizado para a representação de histórias, não numa lógica de substituição, mas de assimilação e transformação. Numa obra de 2011, espécie de manual para a construção de histórias criativas usufruindo das tecnologias da era digital, Bryan Alexander constata precisamente que:

\section{(...) it is vital to realize that people tell stories with nearly} every new piece of communication technology we invent. (...) The motion picture camera elicited cinema. Radio spawned the "theater of the mind." The Lascaux caves either represented scenes of daily life or taught viewers hunting and other tasks. Indeed, no sooner do we invent a medium than do we try to tell stories with it (Alexander, 2011: 5).

Esta constatação remete para a compreensão do narrativo como um impulso universal, inscrito em todas as sociedades de todos os tempos, o que fora já devidamente demonstrado pelos autores da narratologia clássica. Nesse mesmo sentido, estudos no âmbito da psicologia cultural apontam para uma predisposição primitiva e inata do ser humano para organizar a vida em termos de narratividade, para reconstruir vivências individuais e coletivas em cenas narrativas, situando esse movimento antes mesmo da aquisição da linguagem (Bruner, 1998). 
Com efeito, a experiência narrativa mantém também ligação direta a estruturas psíquicas - tema que tem interessado a estudiosos das várias ciências da mente - para além de estar umbilicalmente ligada à cultura, por meio da linguagem e de valores partilhados - os quais, não raro, transcendem o tempo presente, conectados que estão a outros momentos históricos da aventura humana. Nessa linha, Motta (2007: 143) menciona que "a nossa biografia, por exemplo, não é apenas uma autoperceção do nosso $e u$. Ser um $e u$ com passado e futuro não é ser um agente independente, mas estar imerso em relações, em sequências globais dirigidas a metas". O ser humano recorre, portanto, à narrativa como forma de se situar historicamente e numa lógica de apropriação do mundo (Lits, 2015). Muita dessa problemática, aliás, afigura-se como fio nodal da reflexão de Roland Barthes acerca da transculturalidade e da transhistoricidade da narrativa:

Inumeráveis são as narrativas do mundo. Há em primeiro lugar uma variedade prodigiosa de géneros, distribuídos entre substâncias diferentes, como se toda matéria fosse boa para que o homem lhe confiasse as suas narrativas: a narrativa pode ser sustentada pela linguagem articulada, oral ou escrita, pela imagem, fixa ou móvel, pelo gesto ou pela mistura ordenada de todas estas substâncias; está presente no mito, na lenda, na fábula, no conto, na novela, na epopeia, na história, na tragédia, no drama, na comédia, na pantomima, na pintura (recorde-se a Santa Úrsula de Carpaccio), no vitral, no cinema, nas histórias em quadradinhos, no fait divers, na conversação. (Barthes, 1966: 2)1.

Na senda de Barthes, para quem o estudo da narrativa deveria constituir um dos mais importantes inquéritos às sociedades humanas, entende-se que a compreensão da evolução das narrativas

1 Tradução nossa. 
e da sua adaptação constante a novos formatos possibilitados pela evolução tecnológica é essencial para o estudo das relações entre sociedade e indivíduo. Do mesmo modo, Paul Ricoeur refletira já sobre o impulso narrativo universal, de que falamos, quando afirmava que "existe entre a atividade de contar uma história e o caráter temporal da experiência humana uma correlação que não é puramente acidental, mas apresenta uma forma de necessidade transcultural." (Ricoeur, 1987: 85).

Assim, perspetivar os media sob o prisma narratológico também é importante porque nos permite perceber de que forma o conhecimento, os sentidos, os valores são reproduzidos e circulam na sociedade. Porém, as narrativas mediáticas não representam apenas o mundo real: elas providenciam igualmente esquemas mentais e formas de moldar os nossos modos de percecionar, conhecer e acreditar, tendo substituído, na pós-modernidade, as grandes narrativas de legitimação antes veiculadas pela literatura.

Se, na Antiguidade, eram os mitos as grandes narrativas estruturantes da civilização, atualmente os grandes produtores de narrativas são os media. Responsáveis pelo modo como organizamos o mundo, como geramos imagens do real, como articulamos e lemos a sua complexidade, as narrativas mediáticas - ficcionais ou factuais - produzem crenças sociais, ditam normas de conduta, disseminam estereótipos e fornecem-nos imagens dos outros. Pode mesmo afirmar-se, em consonância com alguns autores, que o mundo a que temos acesso se constrói necessariamente de acordo com certos princípios narrativos, pois que o pensamento, as estruturas mentais e o conhecimento se processam por meio da narrativa. Desde os folhetins televisivos, aos reality-shows, passando pelas rubricas desportivas da imprensa ou pelos videojogos, aquilo que os media hoje disseminam é um conjunto de narrativas, em que a ficção e a factualidade se hibridizam, matizando as suas fronteiras (Barthes, 1957/2007; Lyotard, 1989; Lits, 2008 e 2015; Salmon, 2012). 
Esse esbatimento de fronteiras entre os planos factual e ficcional é, sem dúvida, ainda mais preocupante quando o próprio jornalismo, influenciado por lógicas diversas, fere o protocolo comunicacional mantido com o público. A esse propósito, não será descabido relembrar o pensamento de Maria Augusta Babo que, em artigo sobre ficcionalidade e processos comunicacionais, defende a inexistência de quaisquer elementos linguísticos a partir dos quais se possa identificar o substrato factual ou ficcional de uma narrativa, mesmo a jornalística; para a autora, essa identificação é feita a um segundo nível, ao nível translinguístico (Babo, 1996). No caso do jornalismo, a fronteira reside naquilo a que Miguel Rodrigo Alsina (2009: 49) chama "contrato tácito fiduciário" entre jornalistas e público, que, apesar de jamais ter sido formalmente assinado, preside à nossa relação com os produtos noticiosos. Este contrato é, na verdade, a única fronteira entre os dois tipos de narrativa, assentando naquilo que Umberto Eco chamou de "protocolos". Na obra Seis Passeios nos Bosques da Ficção, Eco dá diversos exemplos de procedimentos metalépticos que, anunciando já a alteração profunda das narrativas do espaço público contemporâneo, também ilustram a fluidez de limites entre as "narrativas naturais" e as "narrativas ficcionais" (Eco, 1997: 123-147).

Está ainda por fazer o estudo circunstanciado e sistemático da evolução e transformação das narrativas jornalísticas, embora nos pareça ser esta uma questão central para perceber a própria evolução das formas de fazer e pensar o jornalismo e os media. Se é certo que a narrativa, pelas qualidades de objetivação, temporalidade e exteriorização que comporta - sublinhadas nas definições que diversos autores apresentam de narratividade (Prince, 1987; Reis, 2011) - sempre foi a superestrutura textual que melhor se adaptou ao jornalismo, também não é menos verdade que a lógica narrativa e da narrativa (Herman, 2004) se foi alterando ao longo dos tempos, tendo sofrido, de há uma década a esta parte, modificações assinaláveis. Na linha do trabalho 
desenvolvido pelo Observatoire sur les Médias et le Journalisme, Marc Lits sugere mesmo uma reinvenção da "narratologia" como resposta epistemológica às mudanças profundas que, sobretudo nas duas últimas décadas, afetaram as narrativas mediáticas:

O que a narrativa mediática contemporânea impõe é uma redefinição das próprias condições de existência da narrativa atual, com recurso a uma narratologia refundada, a uma hipernarratologia. É esta abordagem, considerando simultaneamente os avanços tecnológicos, os novos suportes, as evoluções dos usos e dos públicos, que permitirá apreender o homem socializado enquanto animal narrativizado, atravessado por narrativas construídas de acordo com formas radicalmente novas e abertas (Lits, 2015: 27).

Estranhamente e em contraciclo com o que sucede noutros países, os estudos narrativos parecem ser, sem dúvida, uma das áreas mais carenciadas em Portugal ao nível dos estudos sobre media e jornalismo, embora seja indiscutivelmente uma das áreas mais relevantes, sem a qual não se conseguem perceber os fenómenos de produção e de receção dos produtos mediáticos. Convém, contudo, enumerar algumas honrosas exceções, nomeadamente os estudos sobre teleficção desenvolvidos por Isabel Ferin $(2003 ; 2006 ; 2011)$ e, mais recentemente, por Catarina Burnay $(2005 ; 2014)$ e Fernanda Castilho (2014); a recente organização de eventos científicos sobre este campo de estudos: o primeiro - Narrativa, Media e Cognição - teve lugar em 2014, na Universidade do Minho e foi organizado pelo CECS e coordenado por Nelson Zagalo, dele resultando o livro digital Abordagens Narrativas nos Media, publicado em 2015; o segundo colóquio foi organizado pelo grupo de investigação CITAR da Universidade Católica Portuguesa sobre Narrativa, Media e Cognição, e teve lugar em julho de 2015; finalmente, refira-se o projeto de investigação Figuras da 
Ficção ${ }^{2}$, coordenado por Carlos Reis no CLP (Centro de Literatura Portuguesa da Faculdade de Letras da Universidade de Coimbra), como exemplo de uma investigação sistemática e aprofundada sobre personagem - mas não se restringindo a ela - que congrega, de modo integrado, saberes provenientes quer dos Estudos Literários, quer dos Estudos sobre Media.

Pretendem os editores deste livro reunir um conjunto de contributos de especialistas lusófonos, quer dos Estudos Narrativos, quer dos Estudos de Comunicação, contribuindo para a construção de uma visão crítica das narrativas mediáticas no campo da lusofonia. Têm como objetivos gerais, fundamentalmente: i) Reunir o que de mais recente se tem estudado no âmbito dos Estudos Narrativos Mediáticos no mundo lusófono, nomeadamente em Portugal e no Brasil; ii) Constituir um estado da arte de algumas problemáticas desta área de estudos; iii) Funcionar como ponto de partida para eventuais projetos e investigações futuras que reúnam investigadores das Ciências da Comunicação e dos Estudos Narrativos de ambos os países; iv) Contribuir para a análise, problematização e explicação de alguns fenómenos mediáticos contemporâneos.

Os catorze artigos aqui reunidos aparecem organizados por forma a dar resposta a um conjunto de objetivos específicos, que presidiram à construção da obra. Por um lado, houve a preocupação de integrar o estudo dos media numa mais ampla reflexão teórica sobre narrativa, com contributos de especialistas quer das Ciências da Comunicação, quer dos Estudos Narrativos e dos Estudos Literários. Entendemos que a compreensão do funcionamento das narrativas mediáticas, objeto complexo e multímodo, exige um olhar interdisciplinar, capaz de congregar metodologias, conceitos e perspetivas de áreas disciplinares diversificadas. Por outro lado, por uma questão

\footnotetext{
${ }^{2}$ https://figurasdaficcao.wordpress.com/
} 
meramente metodológica, decidiu-se definir quatro eixos de intervenção correspondentes a quatro grandes áreas de estudo.

Assim, organizada em quatro partes, esta obra reúne contributos de investigadores e académicos de formações e áreas diversas, quer brasileiros, quer portugueses, que refletem e problematizam questões sobre a construção, a circulação e o funcionamento das narrativas no espaço mediático hodierno. A primeira parte - "Fenomenologia da Narrativa" - pretende constituir-se como referencial teórico para as grandes questões do narrativo: da reflexão sobre as clivagens entre o ficcional e o factual, suscitadas pelo texto de Carlos Reis, até à perceção da narrativa como essência do humano, como "máquina de antropomorfização", metáfora que sustenta a reflexão de Maria Augusta Babo, passando pela reflexão proposta por Luiz Gonzaga Motta acerca da teoria da narrativa como teoria da ação comunicativa.

Partindo de uma leitura particular da filmografia de Woody Allen, Carlos Reis, coautor do primeiro e único até ao momento Dicionário de Narratologia português, explora os procedimentos metalépticos das narrativas mediáticas, focando especial atenção na categoria personagem, "lugar indeciso em que ficcionalidade e não-ficcionalidade são objeto de insistente subversão paródica". Cruzando conceitos teóricos como figuração, ficcionalidade, narratividade, com exemplos concretos quer do cinema, quer da literatura, o autor abre pistas de reflexão e de estudo, muito fecundas para quem se debruça sobre as narrativas multimédia da atualidade, realçando sobretudo o poder representacional da imagem na construção de universos oscilantes entre ficção e factualidade. Um dos pioneiros no estudo da narrativa mediática no Brasil - autor de Análise Crítica da Narrativa, na qual esboça um modelo de análise próprio, com base em ferramentas provenientes dos estudos narrativos - Luiz Gonzaga Motta convida o leitor "a encarar a narração como um ato de fala comunicativo, e utilizar o modelo dos círculos dêiticos concêntricos para tornar mais sistemático o processo de identificação dos traços e vestígios do contexto 
no texto". Já Maria Augusta Babo, depois de uma circunstanciada síntese crítica sobre as diferentes abordagens a conceitos teóricos fundamentais deste campo de estudos - temporalidade, narrativa, narração, discurso, ação - aprofunda as relações entre a narrativa da história e a ficção, para refletir sobre o poder da narrativa como "máquina" de construção do humano, mesmo num tempo de crise do sujeito, de fragmentação hipertextual e de pulverização de sentidos.

Nas segunda e terceira partes da obra, "Imprensa e Narrativa" e "Personagem Mediática", respetivamente, reúnem-se contributos pontuais sobre questões mais específicas das narrativas mediáticas: na segunda parte, quatro autores problematizam as relações entre narrativa e jornalismo, quer em termos de narrativa de imprensa, quer em termos de narrativa e imprensa; na terceira parte, as abordagens focam-se numa das categorias mais importantes da narrativa - a personagem - recentemente recuperada pelos Estudos Narrativos, depois de décadas de apagamento a que fora votada pelo estruturalismo. Adotando os conflitos no território palestino - uma "geografia violentada", nas palavras do autor - como desafio para pensar o papel da imprensa, Fernando Resende, renomado investigador brasileiro no estudo das narrativas mediáticas, desenvolve uma cuidadosa discussão sobre o conceito de narrativa, focando especial atenção nas limitações das narrativas da imprensa, que, "quase sempre fragmentadas, desprendidas umas das outras, narram os fatos como se eles fossem desprovidos de contextos, deixando que nelas prevaleçam as dicotomias e os binarismos". Igualmente concentrado nas narrativas produzidas pela imprensa, Bruno Araújo expõe alguns dos contributos dos Estudos Narrativos para as teorias do jornalismo, salientando que este último possui um dever de máxima referencialidade com o real, que deve ser mantido sob pena de subversão do protocolo comunicacional estabelecido com leitor. Cruzando ferramentas dos estudos críticos do discurso com categorias oriundas dos estudos literários, o autor analisa as narrativas de duas revistas brasileiras sobre uma 
manifestação de estudantes da Universidade de São Paulo, com o objetivo de identificar as estratégias discursivas que contribuíram para a construção narrativa do acontecimento.

Também a imprensa serve de terreno de exploração empírica para a reflexão de Hélder Prior, investigador português, que busca compreender os graus de narratividade nos relatos mediáticos sobre o escândalo político. Depois de uma incursão pelas diferentes aceções da palavra "escândalo" ao longo dos séculos, o autor recorre a exemplos concretos da imprensa portuguesa, para colocar em evidência "as características eminentemente dramáticas e estéticas dos escândalos mediáticos", demonstrando que esses fenómenos "se desenvolvem na esfera pública como narrativas complexas que têm conflitos, episódios, personagens e efeitos de sentido inerentes ao trabalho jornalístico de recomposição da realidade". Finalmente, a fechar esta segunda parte da obra, Jacinto Godinho, jornalista e académico português, dedica o seu artigo à reportagem, género narrativo nobre do jornalismo, que, na sua relação de contiguidade com a literatura, coloca estimulantes questões, quer do ponto de vista técnico-compositivo, quer do ponto de vista ético-deontológico: a relação entre o verídico e o verosímil, o dilema objetividade versus subjetividade. Trata-se, no fundo, de tentar perceber qual o contributo específico da reportagem para a inteligibilidade do real.

$\mathrm{Na}$ parte seguinte, reúnem-se quatro declinações sobre o tema personagem mediática, com vista a problematizar a sua figuração, tanto em narrativas factuais, quanto em formatos ficcionais, como filmes ou romances. A reflexão é iniciada com um artigo de Ana Paula Arnaut, especialista em literatura portuguesa da pós-modernidade, que analisa as implicações de migrações transmediáticas, com base nas adaptações cinematográficas de duas obras de José Saramago. De seguida, Aletheia Vieira e Liziane Guazina demonstram a vitalidade da teoria da narrativa na análise da construção de personagens jornalísticas, por meio do estudo da caracterização de 
José Dirceu, ex-ministro de Lula da Silva, na revista brasileira Veja. Em diálogo com o pensamento de Campbell acerca da construção do herói, as autoras mostram como "a revista se apropria, mesmo que de forma involuntária, das fases atribuídas por Campbell aos heróis das narrativas ficcionais", criando, contudo, um ciclo narrativo que desloca o político da condição de herói para a condição de anti-herói da sociedade brasileira.

Por seu turno, Célia Ladeira Mota e Leylianne Alves Vieira debruçam-se sobre narrativas ficcionais e jornalísticas, para perceber como a figura do brasileiro é representado na obra Macunaíma, de Mário de Andrade, e na reportagem "O canavial esmaga o homem", de Realidade - revista que circulou, no Brasil, em meados do século $\mathrm{XX}$, destacando-se pelo investimento em reportagens de grande fôlego. Em sua análise, as autoras escrutinam as "subjetividades dos relatos e os contrastes entre a fantasia e a realidade", procurando compreender os significados construídos nos níveis mais profundos de ambas as diegeses. A fechar esta secção, Ana Teresa Peixinho e Bruno Araújo trabalham o conceito de personagem no âmbito de uma narrativa fílmica, procurando perceber de que modo a narrativa da desconfiança que emerge dos media brasileiros é construída sobretudo através do investimento em procedimentos de figuração.

A quarta e última parte do livro, intitulada "A Narrativa nos media digitais", propõe três abordagens ao funcionamento das narrativas no mundo digital, que dão conta das mudanças estruturais e comunicacionais que afetam as narrativas que circulam na WEB: a de João Canavilhas et al. que parte dos conceitos de "tessitura da narrativa" e de "ecossistema mediático" para analisar as novas narrativas desenvolvidas para dispositivos móveis; a de Daniela Maduro que se debruça sobre a questão da interatividade na literatura digital; e a de Fernanda Castilho que procura demonstrar como a lógica produtiva dos conteúdos ficcionais, que iniciou um percurso integrado de construção de novos mundos possíveis, é hoje marcado pelo 
aparecimento de narrativas transmedia, que assentam na produção de experiências ficcionais mais alargadas, extrapolando os limites da televisão.

\section{REFERÊNCIAS BIBLIOGRÁFICAS}

ALEXANDER, B. (2011). The New Digital Storytelling. Creating Narratives with New Media. Oxford: Praeger.

ALSINA, M. R. (2009). A construção da Notícia. Petrópolis: Vozes.

BABO, M. A. (1996). "Ficcionalidade e processos comunicacionais". In: www.bocc.ubi.pt

BARTHES, R. (1966). "Introduction à l'Analyse Structurale des récits". Communications, N. ${ }^{\circ} 8$, pp. $1-27$.

BARTHES, R. (1957/2007). Mitologias. Lisboa: Edições 70.

BRUNER, J. (1998). Actos de significado. Madrid: Alianza.

CANAVILHAS, J. (Org.) (2014). Webjornalismo. 7 caraterísticas que marcam a diferença. Covilhã: LabCom

ECO, U. (1997). "Protocolos Ficcionais". In: Seis Passeios nos Bosques da Ficção. Lisboa: Difel, pp. 123-147.

FIGUEIRA, J. (2014). O acontecimento que quer ser notícia : a construção de sentido das organizações através dos media : o caso "A Vida é Bela". Tese de Doutoramento em Ciências da Comunicação. Faculdade de Letras da Universidade de Coimbra.

HERMAN, D. (2004). "Toward a transmedial narratology". In: Ryan, Marie-Laure (Ed.). Narrative Across Media, pp. 47-72.

LITS, M. (2008). Du récit au récit médiatique. Bruxelles: De Boeck.

LITS, M. (2015). "As investigações sobre a narrativa mediática e o futuro da imprensa". In: Mediapolis, N. ${ }^{\circ} 1$, Coimbra: IUC, pp. 15-29.

LYOTARD, J.-Fr. (1989). La condition Postmoderne. Paris: Editions Minuit.

MOTTA, L. G. (2007). "Análise pragmática da narrativa". In: LAGO, C.; BENETTI, M. Metodologia de pesquisa em jornalismo. Petrópolis: Vozes, pp. 143-167.

PRINCE, G. (1987). Narratology. The Form and Functioning of Narrative. Berlin / New York: Mouton Publishers. 
REIS, C.; LOPES, A. C. (2011). Dicionário de Narratologia. $7 .^{\mathrm{a}}$ ed. Coimbra: Livraria Almedina.

RICOEUR, P. (1987). Temps et Récit. Paris: Seuil.

RYAN, M-L. (2009). "Narrative in various media". In: Hung, Peter et al. (Eds.) Handbook of Narratology. Berlin/New York: Walter de Gruyter, pp. 263-281.

RYAN, M-L. (2013). "Transmedial Storytelling and Transfictionality." Poetics Today 34.3, pp. 362-388.

SAlMON, C. (2010). Kate Moss Machine. Paris: La Découverte.

WALSH, R. (2011). "Emergent Narrative in Interactive Media”. In: Narrative, Vol. 19, N. ${ }^{\circ} 1$ (January), Ohio: Ohio State University, pp. 72-85.

VAN DIJK, J. (2005). The Network Society. Social Aspects of New Media. London: Sage Publication.

\section{Ana Teresa Peixinbo \\ Bruno Araújo}


(Página deixada propositadamente em branco.) 


$$
-
$$





\section{WOODY ALLEN OU A FICÇÃO COMO JOGO: \\ O CASO ZELIG}

Carlos Reis

Centro de Literatura Portuguesa/UC

1. Alguns tópicos de reflexão, ainda em jeito de abertura. Assim: se falamos da narrativa e do conhecimento que ela permite, falamos também de um modo discursivo cujo projeto fundamental é eliminar aquilo que de transitório e fugaz existe nas ações humanas; pela narrativa conferimos estabilidade discursiva a essas ações (que são ações de mudança e em mudança) e procuramos dar sentido a acontecimentos que, aquém da elaboração narrativa, parecem dispersos e desarticulados.

Por outro lado, uma realidade vivida por entidades humanas pode ganhar autonomia, quando a configuramos e a lemos como ficção: a ficção é, então, condição para a transcendência (como quem diz, para uma certa forma de permanência transnarrativa) daquilo que eventualmente decorre de experiências de vida concretas. Daí podermos afirmar que atingimos um certo nível de conhecimento através da narrativa: conhecimento de atos dos homens, de experiências de vida, de situações sociais e mentais, etc. Esse conhecimento não é posto em causa pela condição ficcional das narrativas, sendo certo, contudo, que essa condição solicita atitudes cognitivas, culturais e emotivas específicas, em grande parte relacionadas com aquilo 
a que generalizadamente chamamos, desde a famosa postulação de Coleridge, suspensão voluntária da descrença.

O cinema de Woody Allen e o filme Zelig encenam, de forma extremamente sugestiva, os termos em que a ficção se exibe como jogo, sem que assim se ponha em causa o potencial de conhecimento que ficou referido. Conhecimento narrativo de um fenómeno efémero e, adianto desde já, busca de sentido e de prolongamento no tempo daquele fenómeno, como exemplaridade a reter. É assim que em Zelig leremos uma tentativa (brilhante, a meu ver) de, pela narrativa, se proceder a uma exegese do mundo; no caso em apreço, esse mundo é o de um sujeito apresentado como figura real, que dá pelo nome de Leonard Zelig.

2. Antes de chegar a Zelig, farei um desvio por várias questões que nele estão implicadas, dizendo respeito, em geral, às respostas que é possível encontrar para a pergunta: como reconhecemos uma narrativa, quando a lemos (ou quando a ouvimos; ou quando a vemos)? Se tal fosse possível, neste local e neste momento, aquelas respostas seriam apoiadas por uma reflexão acerca de diversos aspetos da existência e do funcionamento das narrativas, no plano material e no plano semiodiscursivo. De modo que faço aqui um inevitável bypass que deixa em aberto, talvez para outra altura, indagações em torno do canal de comunicação narrativa (visual, auditivo, tátil), dos suportes e da sua especificidade (incluindo a distinção analógico/ digital), das linguagens de enunciação (verbal, verbo-icónica) e também dos efeitos cognitivos deduzidos destas escolhas. Não deixo, contudo, de assinalar que os trabalhos de Marie-Laure Ryan são, neste e noutros domínios, de muito boa ajuda (cf. Ryan (ed.), 2004; Ryan, 2006; Ryan e Thon (eds.), 2014).

Reconhecer uma narrativa é, antes de mais, aderir a uma sua propriedade nuclear, a narratividade, em dois planos que podem ser conjugados. No plano da funcionalidade discursiva, a narratividade 
é entendida como um "conjunto de propriedades que caracterizam a narrativa e que a distinguem da não-narrativa", correspondendo aquelas propriedades às "características formais e contextuais que fazem de um texto (narrativo) mais ou menos narrativo" (Prince, 2003: 65). Para além deste plano funcional (que é basilar, mas deve ser alargado), a narratividade concretiza-se como experiência humana com um certo índice de naturalização, numa abordagem que é já de feição cognitivista.

A chamada narratologia natural contempla este campo de análise e argumenta que a "narratividade é uma função dos textos narrativos e centra-se numa experiencialidade de natureza antropomórfica" (Fludernik, 1996: 26). Nesta aceção, faz sentido falar em narrativização como princípio de interpretação e como estratégia de leitura; uma tal estratégia de leitura narrativística compensa as inconsistências e as incompletudes de uma narrativa (porque ela nunca conta tudo) pelo recurso a esquemas narrativos previamente naturalizados, com base na nossa experiência empírica e nas práticas narrativas que a cada momento ela propicia. Daqui chegamos a um conceito ao mesmo tempo elementar e muito aberto de narrativização, como processo que convoca a narratividade: a narrativização é "a leitura dos textos como narrativos, como constitutivos de narratividade no processo de leitura" (Fludernik, 1996: 20). A abertura pan-narrativista que daqui se infere é evidente: para além do que lemos na prosa narrativa, a narratividade está disseminada na poesia e nos textos dramáticos e pode ser nuclear em discursos verbais, icónicos e verbo-icónicos que encontramos no cinema, na televisão, na imprensa, etc. (veja-se Prince, 2005; Abbott, s.d.).

3. Antes de chegarmos a Zelig, recordemos alguns antecedentes e desenvolvimentos possíveis. Os antecedentes do que fica dito estão no pensamento e nas propostas de Roland Barthes, explanado num número hoje histórico (porque fundacional) da revista Communications. 
No seu texto de abertura (e no seu incipit, lugar de destaque, tal como acontece em certas narrativas), Barthes escreveu:

Inumeráveis são as narrativas do mundo. Há em primeiro lugar uma variedade prodigiosa de géneros, distribuídos entre substâncias diferentes, como se toda matéria fosse boa para que o homem lhe confiasse as suas narrativas: a narrativa pode ser sustentada pela linguagem articulada, oral ou escrita, pela imagem, fixa ou móvel, pelo gesto ou pela mistura ordenada de todas estas substâncias; está presente no mito, na lenda, na fábula, no conto, na novela, na epopeia, na história, na tragédia, no drama, na comédia, na pantomima, na pintura (...), no vitral, no cinema, nas histórias em quadradinhos, no fait divers, na conversação (Barthes, 1966: 1).

O que veio depois e pudemos ler nos trabalhos inspirados pela análise estrutural da narrativa (logo naquele número de Communications, mas não só nele) e pela narratologia de inspiração genettiana dos anos 70 e 80 é sabido e não precisa de ser lembrado, a não ser para sublinhar o seguinte: no tocante aos estudos narrativos, ao seu potencial operatório e às bases epistemológicas em que eles se sustentam, não estaríamos onde estamos sem o contributo daqueles trabalhos.

Depois deles e episodicamente em diálogo com eles, a filosofia da narrativa plasmada nos magistrais estudos consagrados por Paul Ricoeur ao tempo narrativo abriu caminhos de reflexão hermenêutica que encontramos sintetizados na "hipótese de base" que rege o trabalho do grande pensador francês. Diz Ricoeur, num dos volumes de Temps et récit: "Existe entre a atividade de contar uma história e o caráter temporal da experiência humana uma correlação que não é puramente acidental, mas apresenta uma forma de necessidade transcultural." E acrescenta: "o tempo torna-se tempo humano na medida em que é articulado em modo narrativo, e (...) a narrativa 
atinge a sua significação plena quando se torna uma condição da existência temporal" (Ricoeur, 1983: 85).

Sintomaticamente, é também a experiência humana que aparece invocada no ensaio em que Jerome Bruner conjuga psicologia cognitiva e teoria da aprendizagem. Entendendo as narrativas como uma versão da realidade suportada por aquilo a que chama "necessidade narrativa", Bruner nota: "Organizamos a nossa experiência e a nossa memória dos acontecimentos humanos principalmente em forma narrativa - histórias, desculpas, mitos, razões para fazer e para não fazer e assim por diante" (Bruner, 1991: 4) 3 $^{3}$ O que nos traz de volta à naturalização da narrativa de que anteriormente falei. Toda a narrativa constitui, em suma, um procedimento alargado, consistente e consequente de construção de sentido, com uma dimensão humana e com um "formato" temporal que são reversíveis e interativos. Derivadamente, a narrativa traduz um impulso de prolongamento daquilo que parece transitório e contingente; a isto junta-se a sua capacidade de modelização secundária ${ }^{4}$ de ações humanas, de acordo com a condição ficcional (que é também uma condição narrativa) da personagem e com o processo de figuração que ela implica.

É pela narrativa ficcional (e em particular pela narrativa ficcional literária) que tentamos resolver a tensão entre autonomia e heteronomia que é própria das práticas artísticas. Lemos as ficções narrativas literárias como representações autónomas de experiências humanas que, de facto, nos são alheias, no plano empírico; mas ao mesmo tempo, persistimos em ler essas ficções porque reconhecemos nelas

\footnotetext{
${ }^{3}$ Acrescenta Bruner: "As narrativas são, então, uma versão da realidade cuja aceitabilidade é regida por convenção e por 'necessidade narrativa', mais do que por verificação empírica e exigência lógica, embora ironicamente não tenhamos escrúpulo em chamar às histórias verdadeiras ou falsas" (Bruner, 1991: 4-5).

${ }^{4}$ A modelização secundária que a narrativa literária concretiza "opera com as fundamentais categorias da narrativa, do tempo ao modo, passando pela personagem, pela representação do espaço e pela estruturação da ação" (Reis e Lopes, 2011: 236).
} 
uma evidente dinâmica de pervivência daquilo que nelas é dito e vivido por "pessoas de livro"'.

Sendo em princípio localizados e contingentes, esses atos e essas palavras reacendem, no nosso tempo e nas nossas vidas, sentidos que, por fim, transcendem as ficções narrativas em que se encontram disponíveis, para com elas interagirmos. Não cavalgamos Rocinante, em investida contra moinhos de vento, nem tentamos impedir Dom Quixote de o fazer (deixamos isso por conta de Sancho Pança); mas aquele gesto supostamente tresloucado continua a convocar as nossas emoções, quando a ele reagimos, com solidária cumplicidade ou com risonha compreensão. A vida da obra (Ingarden dixit) e a decorrente sobrevida das personagens são, afinal, da mesma natureza daquela perenidade artística que Eça ilustrou com uma história de amor (com uma narrativa) chamada Romeu e Julieta: "Shakespeare está realmente tão vivo como quando, no estreito tablado do Globe, ele dependurava a lanterna que devia ser a lua, triste e amorosamente invocada, alumiando o jardim dos Capuletos" (Queirós, 2009: 201).

4. O cinema de Woody Allen envolve, com frequência, temas e motivos literários que são bem notórios. Recordo os títulos da sua extensa filmografia que, neste aspeto, são mais significativos. Aqueles temas emergem, em registo de alusão, de paródia ou de reescrita cinematográfica, em Manhattan (1979), em Uma Comédia Sexual numa Noite de Verão (1982) ou em Balas sobre a Broadway (1994). Não apenas metaliterária, mas também de índole metanarrativa é a conceção e a realização de outros filmes, sobretudo das décadas de 80 e 90, a saber: Zelig (1983), A Rosa Púrpura do Cairo (1985), Os Dias da Rádio (1987), Poderosa Afrodite (1995), As faces de Harry (1997) e ainda o mais tardio Melinda e Melinda (2004) ${ }^{6}$.

\footnotetext{
${ }^{5}$ A expressão "pessoas de livro" encontra-se num passo da História do Cerco de Lisboa, de José Saramago ("pessoas de livro são personagens, contrapôs Maria Sara").

${ }^{6}$ Refiro os títulos dos filmes pela designação que receberam em Portugal.
} 
São sobretudo estes filmes que convidam a uma integração de questões e problemas do âmbito dos estudos narrativos com questões e problemas do âmbito dos estudos mediáticos e, mais especificamente, do campo das relações entre narrativa literária e narrativa cinematográfica. O que requer uma ressalva metodológica importante: sem privilegiar uma leitura de especialidade da narrativa cinematográfica, a análise que me proponho realizar orienta-se para a problematização de aspetos compositivos e de categorias (por exemplo, a personagem), cuja dilucidação poderá ser muito fecunda para o estudo da narrativa, em termos alargados. É nesse sentido que a filmografia de Woody Allen, com toda a evidência, é exemplarmente rica. ${ }^{7}$

Menciono de seguida, e apenas em termos introdutórios, algumas daquelas questões a que chamo paraliterárias e paranarratológicas. Assim:

i. As fronteiras da ficção e o seu estatuto ontológico, bem como a relevância da metalepse e a diluição dos limites dos universos ficcionais, como se vê em A Rosa Púrpura do Cairo ("é tudo uma questão de semântica", diz uma das personagens).

ii. A relação entre ator e personagem ou os condicionamentos do casting, em relação direta com a sobrevida das figuras ficcionais; incluem-se aqui as determinações extra-artísticas e as perversões do dito casting (veja-se Balas sobre a Broadway e, de novo, A Rosa Púrpura do Cairo).

iii. Os processos de figuração da personagem, em relação direta com géneros literários, com as suas injunções representacionais e com os seus efeitos cognitivos (por exemplo, em Melinda $e$ Melinda).

\footnotetext{
${ }^{7}$ No plano pedagógico, a integração a que me referi (estudos narrativos e estudos mediáticos) aconteceu no seminário Estudos Narrativos Mediáticos, que lecionei no doutoramento em Ciências da Comunicação da Faculdade de Letras de Coimbra.
} 
iv. As condições de existência semiodiscursiva dos relatos noticiosos e ficcionais no espaço mediático, bem como os efeitos cognitivos e sociais que decorrem delas e das suas personagens (em Os Dias da Rádio).

v. A relação da personagem e da sua construção com as decisões (ou com as suas limitações) do escritor (As faces de Harry), bem como o peso de mitos ancestrais e de uma tradição cultural em revisão paródica (Poderosa Afrodite).

Quem se lembra de Zelig ou pôde visioná-lo recentemente terá bem presente o que neste admirável filme ${ }^{8}$ se conta. Trata-se da história de uma figura bizarra, alegadamente atingida por uma perturbação psicopatológica que explica o epíteto de homem-camaleão que lhe é atribuído: manifestava-se em Leonard Zelig a tendência para se desdobrar e mimeticamente replicar aquele ou aqueles com quem interagia, naquilo que parecia ser um culto irreprimível da alteridade, atentamente seguido por uma psiquiatra (Dra. Eudora Fletcher); é ela quem tenta a cura desse paciente por quem depois se apaixona. O físico, a linguagem, a indumentária e a gestualidade de Zelig traduziam, de forma algo burlesca, aquela tendência, vivida num contexto histórico particular: o final dos anos 20 e os anos 30, tempo marcado pela depressão da economia norte-americana, na sequência do crash bolsista de 1929, pela ascensão do nazismo e pelo pontificado de Pio XI (1922-1939).

A construção narrativa do filme está dominada por várias estratégias enunciativas. Primeiro: o recurso a uma voz over anónima, numa instância de narração exterior à história, atribuível a um narrador omnisciente e potencialmente fiável. Segundo: uma configuração genológica intermediática e internarrativa, que articula os registos

\footnotetext{
${ }^{8} \mathrm{Na}$ receção que Zelig conheceu, à época em que foi produzido e exibido, contam-se nomeações para prémios de grande destaque (Oscar da Academia, Globo de Ouro e BAFTA), mas nenhuma atribuição efetiva.
} 
do documentário, da reportagem jornalística, da biografia cinematográfica (o chamado "biopic film") e da narrativa historiográfica. Terceiro: a centralidade de Zelig como figura em torno da qual gira todo o relato, centralidade expressa logo no título do filme. Quarto: a oscilação entre procedimentos de veridicção ${ }^{10}$, acentuando a alegada veracidade da figura, e procedimentos de desmontagem desse estatuto, sempre que se põe em causa a mais elementar verosimilhança (por exemplo: de regresso aos Estados Unidos, Zelig pilota um avião que atravessa o Atlântico de cabeça para baixo).

Aquela oscilação gera uma ambivalência que domina todo o filme, afirmando-se como sua decisiva marca identitária. Vale a pena insistir no significado dos estratagemas que servem para construir discursivamente a pseudo-veracidade de Zelig. Antes de mais e logo a abrir o filme: a incorporação narrativa de depoimentos com propósito legitimador. Personalidades destacadas da vida intelectual norte-americana, como Susan Sontag, Irving Howe, Saul Bellow ou Bruno Bettelheim aparecem a dar testemunhos autorizados a propósito do fenómeno Zelig. Para além disso, as várias trucagens sofridas por supostos documentos cinematográficos "de época" reforçam a dimensão histórica e não ficcional de Zelig. A mais evidente dessas trucagens é a que confere aspeto desgastado às películas, com aparência de documentários ou noticiários cinematográficos muito antigos, que ilustram episódios da vida de Zelig, bem como acontecimentos históricos por ele vividos; não menos expressivo (mas porventura excessivo e, por isso, já com feição desconstrutiva e mesmo paródica) é o aparecimento de Zelig ao lado do escritor Scott Fitzgerald e sobretudo o modo como irrompe num comício

\footnotetext{
9 A expressão "biopic film" é uma redução de "biographical pictures" e refere-se a filmes que relatam a biografia de figuras com relevo histórico ou cultural, eventualmente com interpretações e extensões de índole ficcional.

${ }^{10}$ Retomo aqui o conceito semiótico de veridicção como manifestação do dizer-verdade apoiada em ilusões referenciais, processo discursivo dependente de uma conceção imanente da linguagem.
} 
de Hitler, perturbando o discurso do Fürher. E ainda: a alternância da cor com o preto e branco (que Allen voltou a usar em $A$ Rosa Púrpura do Cairo) reforça a diferença entre o passado (preto e branco) e o presente (cor); sendo assim, a Eudora Fletcher do presente não está apenas muito mais velha (e por isso não pode ser interpretada pela mesma Mia Farrow do passado a preto e branco), como também é filmada a cores.

O confronto com esta construção veridictiva e também o seu reforço são estabelecidos pelo recurso a um outro documento de época, este citado como uma ficção. Trata-se do filme The Changing Man, apresentado como uma produção da Warner Brothers, de 1935, que pretende ser a reconstrução ficcional do "caso" Zelig. Por comparação com a elaboração documental e mesmo historiográfica que domina a biografia de Leonard Zelig, o filme da Warner revela-nos uma figura idealizada, o que se acentua ainda pela retórica interpretativa do ator a quem cabe o papel de Zelig. O comício de Munique, em que Eudora reencontra Leonard, permite observar o contraste entre as duas versões; para mais, a segunda é desautorizada por Eudora, que claramente afirma que aquilo que de facto se passou não foi nada parecido com o que vê no filme. E assim, pelo "excesso" da ficção, reforça-se a "autenticidade" daquilo que nos é proposto como evocação de um caso verídico.

5. Trato agora de alargar o que anteriormente foi analisado, no sentido de, em movimento de transnarrativização, tentar identificar três princípios constitutivos do conhecimento narrativo sugeridos por Zelig. Um conhecimento que julgo ser indissociável do reconhecimento da narrativa como tal, dos seus protocolos enunciativos e das suas formulações figuracionais; incidem estas últimas sobre a personagem como categoria central do relato, em direta relação com o sentido humano que nele se elabora. Refiro-me, assim, a três princípios que estruturam a composição de Zelig. 
5.1. Primeiro princípio, o da credibilidade narrativa. Num largo trajeto que vai das poéticas da Antiguidade até às primícias da modernidade, a verosimilhança impõe-se como critério de aceitabilidade e de integração cognitiva da narrativa e em particular da narrativa literária. A credibilidade que pela verosimilhança se estabelece requer, naturalmente, aquela suspensão voluntária da descrença a que já aludi e que pode ser entendida, por outro lado, como uma afirmação de crença no poder evocativo e representacional da palavra literária ${ }^{11}$. Foi esse poder que deu lugar aos realismos e ao seu propósito de narrativizar, normalmente com intuito crítico, situações, conflitos e figuras que nos dão a conhecer tempos e estados das sociedades a que aqueles realismos se reportam. ${ }^{12}$

As poéticas do modernismo e do pós-modernismo não desvalorizaram, bem pelo contrário, o princípio da credibilidade narrativa, mas reajustaram-no em função de uma nova episteme do sujeito, que é proposta pelo pensamento literário e filosófico de Mallarmé e de Nietzsche, de Freud, de T. S. Eliot e de Fernando Pessoa, entre outros. Essa nova episteme, correspondendo também a uma crise do sujeito, cultiva uma retórica da veridicção que assenta na força performativa de atos discursivos literários e metaliterários e na aquisição do desdobramento como evidência daquela crise (o Ultimatum de

\footnotetext{
${ }^{11}$ Recorde-se que, no passo da Biographia Literaria (1817) em que exarou aquele famoso conceito, Coleridge falou também em fé poética. Assim: "That willing suspension of disbelief for the moment, which constitutes poetic faith." (em http://www. english.upenn.edu/ mgamer/Etexts/biographia.html; acesso a 2.1.2016).

${ }^{12}$ São conhecidos os termos em que Engels, numa carta de abril de 1888 (e apesar de diferenças ideológicas que assinala), fez o elogio de Balzac como romancista que retratou a sociedade francesa posterior a 1815. "He describes how the last remnants of this, to him, model society gradually succumbed before the intrusion of the vulgar monied upstart, or were corrupted by him"; e mais adiante: "And around this central picture he groups a complete history of French Society from which, even in economic details (for instance the rearrangement of real and personal property after the Revolution) I have learned more than from all the professed historians, economists, and statisticians of the period together." (carta a Margaret Harkness, em https://www. marxists.org/archive/marx/ works/1888/letters/88_04_15.htm ; acesso a 2.1.2016).
} 
Álvaro de Campos é, neste contexto, um testemunho admirável de força expressiva e nietzschiana).

A construção da heteronímia pessoana é consabidamente um marco relevante a assinalar aquele percurso de mutações ontológicas e epistemológicas. É bem sintomático, aliás, que a sua conceção como drama em gente envolva a noção de personagem (é assim que Pessoa designa os heterónimos), num processo cuja feição paranarrativa parece evidente, muito antes de isso ser confirmado na famosa carta de 1935 a Adolfo Casais Monteiro sobre a génese dos heterónimos ${ }^{13}$. Ao mesmo tempo, não podemos ignorar que a síndrome Zelig e as atribulações do homem-camaleão manifestam-se naqueles anos 30 em que Pessoa ia refinando e aprofundando a sua encenação heteronímica. ${ }^{14}$ Nesse tempo propício a tais aventuras, insinua-se em ambos a credibilidade narrativa como fator de consolidação de trajetos existenciais autónomos; o sentido que nesses trajetos lemos é potenciado justamente por uma naturalização narrativa que lhes dá consistência própria.

É claro que, em Zelig, a credibilidade narrativa desliza (e de certa forma desvanece-se) para uma certa derrisão que nos desdobramentos modernistas escassa ou nulamente transparece. Se o homem-camaleão viveu nos anos 20 e 30 em que a aventura pessoana e outras

\footnotetext{
${ }^{13}$ Num dos seus mais conhecidos textos de reflexão metaliterária, escreveu Pessoa que, "se analisarmos bem aquilo de que se [os géneros] se compõem, verificaremos que da poesia lírica à dramática há uma gradação contínua. Com efeito, e indo às mesmas origens da poesia dramática - Ésquilo por exemplo - será mais certo dizer que encontramos poesia lírica posta na boca de diversos personagens." E noutro passo: "Por qualquer motivo temperamental que me não proponho analisar, nem importa que analise, construí dentro de mim várias personagens distintas entre si e de mim, personagens essas a que atribuí poemas vários que não são como eu, nos meus sentimentos e ideias, os escreveria." (Pessoa, s.d.)

${ }^{14}$ Para além disso, a construção da teoria poética pessoana coincide, em boa parte, com o tempo de desenvolvimento da teoria do romance e da filosofia da linguagem bakhtinianas (Problemas da poética de Dostoievski é de 1929 e O discurso no romance é de 1934-35). Não surpreende, por isso, que os conceitos de pluridiscursividade, de polifonia e de alteridade possam ser relacionados, como já aconteceu, com o universo pessoano e, já agora, com a síndrome Zelig. Cf. Reis, 1989 e, na sequência deste, Vila Maior, 1994.
} 
similares se desenvolveram, a sua conceção, a produção e a realização cinematográfica que lhe deram vida revelam uma marca pós-modernista que é já de outro tempo: com Zelig, estamos agora naqueles anos 80 em que o cinema de Woody Allen se deixou seduzir pelos jogos metaficcionais que encontramos também n'A Rosa Púrpura do Cairo e n'Os Dias da Rádio. Nestes, como em Zelig, a metalepse e a desconstrução paródica são desafios que não dispensam, por vezes, a citação de outras ficções, retomadas no contexto de derrisão que agora está em causa. Não é destituído de significado o facto de Zelig aparecer fotografado como Canio, o ator-palhaço; o desdobramento convoca, neste caso, uma personagem que, na ópera Pagliacci de Leoncavallo, vive dramaticamente a tensão de quem oscila entre a condição de ator e a personagem (Pagliaccio) que ao mesmo tempo vive e rejeita ${ }^{15}$.

5.2. Falo agora do princípio da transhistoricidade, de novo deduzido do que observamos em Zelig; e relaciono-o, antes de mais, com a reconhecida e ancestral vocação da narrativa para dialogar com a História e mesmo para nela interferir. Nesse sentido, a narrativa pode tematizar explicitamente a História (p. ex.: o romance histórico), interagir com ela, propor uma sua interpretação ou até questionar subversivamente heróis e episódios que a historiografia convencional configurou.

É em função do princípio da transhistoricidade que lemos a História no relato ficcional: ele transcende, refaz e prolonga no tempo o passado visado pela História e quem nele habitou, fazendo-o chegar até nós sob forma narrativa. Mais: sem descurar, antes reforçando, a sua dimensão ideológica (e mesmo, por vezes, pedagógica), a narrativa

\footnotetext{
${ }^{15}$ Aquilo a que chamo tensão entre ator e personagem foi glosado, no quadro da encenação dramática propriamente dita e do tratamento do casting, em Balas sobre a Broadway, um filme que, mais do que Zelig, merece um confronto com a ópera mencionada e também, já agora, com Sei personaggi in cerca d'autore, de Pirandello.
} 
ficcional chega a reescrever a História, entendendo-a como imagem precária e suscetível de ser discursivamente superada ${ }^{16}$.

Numa sequência de Zelig, construída com a ajuda de um (pseudo) documentário noticioso onde se nota a patine que o tempo depositou na película cinematográfica, vemos o protagonista numa cena passada em Roma, num Domingo de Páscoa. Nela, Leonard Zelig aparece inopinadamente ao lado de Pio XI e perturba a cerimónia da bênção papal urbi et orbi; perante milhares de fiéis, instala-se então a confusão na varanda principal da Praça de São Pedro, ao ponto de o papa agredir o intruso. Por seu lado, o já citado comício de Munique suscita, muitos anos depois, o comentário de uma testemunha presencial: Oswald Pohl, de quem, em legenda, se diz ser um antigo membro das SS nazis, reconhece que Zelig interferiu no discurso de Hitler, impedindo-o de dizer uma piada sobre a Polónia.

Que o excesso e o absurdo sejam dominantes em ambos os episódios é algo que pouco importa agora. O que interessa é a sugestão que fica: a narrativa, neste caso cultivando uma ambivalência que a faz oscilar entre a lógica do ficcional e a retórica do documental, impõe-se como dispositivo capaz de, conforme escreveu José Saramago, introduzir na História aqueles "pequenos cartuchos que façam explodir o que até então parecia indiscutível". Preside a esse ato aquilo que se apresenta ao grande romancista (e, como se sabe, admirável cultor de ficções metahistoriográficas com intuito ideológico) como "a consciência da nossa incapacidade final para reconstituir o passado" (Saramago, 1990: 19) ${ }^{17}$. Por isso, Saramago concebeu "pequenos cartuchos" chamados Blimunda e Baltasar Sete-Sóis, parentes e cúmplices

\footnotetext{
${ }^{16}$ Aproximo-me aqui das teses de Hayden White (White, 1978: 81-99).

${ }^{17}$ Não se trata, para Saramago, de corrigir ou de reescrever infinitamente a História. Mas é o romancista quem pode empreender uma "espécie de reivindicação ou o ato de chamar à presença", de "reclamar a presença" da História na narrativa que a questiona. (Reis, 2015a: 89).
} 
de Leonard Zelig que, à sua maneira burlesca, nos fez conhecer em Pio XI e em Adolf Hitler comportamentos inusitados. E assim, num outro medium e em tom paródico, o homem-camaleão reafirma o direito (e o poder) que a narrativa reclama para incessantemente reescrever o que por outra narrativa, a da História, fora dito.

5.3. Como se viu, a personagem é um elemento capital da manifestação das virtualidades de tratamento transhistórico que a narrativa encerra. Por isso mesmo, o princípio da figuratividade constitui um fator relevante (e último, por agora) de concretização do conhecimento viabilizado pela narrativa.

Designo aqui por figuratividade a propriedade ou conjunto de propriedades que decorrem dos dispositivos de modelização da personagem como figura ficcional; e chamo genericamente figuração a esses dispositivos e ao seu trabalho narrativo. Retomando o que escrevi noutro local, a figuração pode ser entendida como "um processo ou um conjunto de processos constitutivos de entidades ficcionais de feição antropomórfica, conduzindo à individualização de personagens em universos específicos, com os quais essas personagens interagem" (Reis, 2015b: 121-122 $)^{18}$.

$\mathrm{O}$ caso Zelig e a forma como é narrativamente representado revela-se-nos um contributo significativo para apurarmos alguns aspetos do mencionado princípio da figuratividade, enquanto componente que colabora na estruturação do relato. Com Zelig e, mais alargadamente, com a figuração da personagem é pelo nome que

\footnotetext{
${ }^{18}$ Acrescento ao que fica dito: "Tal individualização verifica-se sobretudo em contextos narrativos e em contextos dramáticos, mas acontece, igualmente de modo residual, em contextos de enunciação poética; passa-se isto, em especial, quando estão em causa composições dotadas de um certo índice de narratividade. Ou seja: a personagem pode ser figurada na poesia lírica. Por outro lado, a figuração deve ser encarada em aceção translata, quando observamos a sua ocorrência em discursos que não são formal ou institucionalmente literários. Refiro-me, por exemplo, à historiografia, à epistolografia e aos discursos de imprensa (p. ex., os retratos de figuras públicas, os obituários, etc.)." (Reis, 2015b: 122)
} 
tudo começa. Ou melhor, pela sua procura, como se a personagem fosse (e de facto é) uma entidade dinâmica, parecendo o próprio nome, nas primeiras abordagens, um componente em movimento: Leon Selwin ou Zelman são as denominações anotadas pelo romancista Scott Fitzgerald, primeira testemunha convocada para, logo no início do relato, dar a conhecer a figura que vai ser biografada. Sintomaticamente, é pelo registo de um ficcionista que essa figura começa a tomar forma e condição humana. Mais: a voz over do narrador lembra que, como romancista, foi Fitzgerald quem registou os anos 20 da vida norte-americana para as gerações futuras. Fica assim exarado um atestado de autoridade que, ao mesmo tempo que confere credibilidade ao caso em desenvolvimento, traz à cena da narrativa o trabalho de um ficcionista, em cuja esfera de ação ambiguamente Zelig é colocado.

As variações sobre o nome (quando aparece num treino dos Yankees, o jogador desconhecido chama-se agora Lou Zelig) não são inconsequentes. Elas anunciam outras variações, mais complexas e mais problemáticas, assim se insinuando aquele que é um modo de caracterização por vezes presente na figuração da personagem: a relação de coerência entre o nome (neste caso, a sua indefinição inicial) e a personalidade.

As mencionadas variações são o fulcro da identidade mutável de Zelig. Mimetizando constantemente o outro com quem interage, Zelig é uma figura em incessante busca e reconstrução, assim se sugerindo que o conhecimento da personagem é, de forma correlata, um processo sempre em aberto. $\mathrm{O}$ que bem pode ser confirmado, num outro plano de análise, por quem nos diz que "o conceito de personagem já não é um conceito estático" (Felski, 2011: V), a isto podendo acrescentar-se o seguinte: "Sem dúvida, uma certa conceção do que constitui uma personagem - uma ideia de personalidade unificada, imutável, intrínseca ou impermeável - já não é sustentável em bases teóricas ou históricas" (Felski, 2011: IX). 
6. Para terminar: o processo de narrativização a que assistimos em Zelig depende, em grande parte, de reconhecermos como narrativa aquilo que o é, com base na nossa experiência de produtores e de consumidores de relatos, desde os do nosso quotidiano até às ficções mais elaboradas. Os princípios que descrevi (da credibilidade, da transhistoricidade e da figuratividade) contribuem para refinar culturalmente a funcionalidade das narrativas, ao mesmo tempo que requerem uma competência de leitura a que podemos chamar literacia narrativa.

É a nossa literacia narrativa que recorrentemente é interpelada por Zelig. Acontece assim sobretudo quando nos damos conta daquela ambivalência de que anteriormente falei e que é instaurada por uma certa hibridização de procedimentos: discursos e estratégias veridictivas convivem e alternam com o excesso da paródia que desmistifica a "autenticidade" histórica da figura e dos episódios que ela vive.

$\mathrm{O}$ casting e as suas exigências colaboram naquela hibridização. Começamos a ver aquilo que, por força de vários estratagemas retóricos, tem a aparência de um documentário, mas logo nos apercebemos de que a figura central dessa biografia documentada e atestada por várias formas é interpretada por um ator que conhecemos: Woody Allen. Logo de seguida, a Dra. Eudora Fletcher (mencionada na abertura do filme como destinatária de agradecimentos, como é usual em documentários) tem o rosto da atriz Mia Farrow.

Estaria desfeita, logo deste modo, a tal ambivalência (o casting "diz-nos" que, afinal, o filme conta uma ficção, pela interpretação de atores conhecidos), se não se desse o caso de, pouco depois, aparecer, a cores, a Dra. Eudora Fletcher envelhecida mas não identificável com nenhuma atriz conhecida. Quero dizer, como se se tratasse de uma pessoa real, no mesmo plano ontológico de Susan Sontag, de Saul Bellow ou de Bruno Bettelheim. Acentua-se esta tentativa de recuperar a veridicção pelo facto de aquele papel de Eudora-envelhecida ser desempenhado (afinal, alguém tinha de o fazer...) por Ellen 
Garrison, que nunca fora (nem voltou a ser) atriz na sua vida ${ }^{19}$. Nada disto se confunde, note-se, com a mais convencional situação do biopic film: aqui, sem trucagens nem ambiguidades, um ator encarna uma personalidade real, num registo desde logo reconhecido como o de um filme biográfico com propósito artístico e, não raro, com derivações ficcionais (por exemplo: Daniel Day-Lewis fazendo de Abraham Lincoln ou Philippe Seymour Hoffman de Truman Capote).

No fim de contas, Zelig deixa-nos várias interrogações, perversamente induzidas pelos jogos metaficcionais que nele se desenrolam. Uma dessas interrogações: não será próprio de toda a narrativa o culto daquela espécie de vacilação entre o testemunho que afirma o verídico e a tentação pela ficção? Outra questão: não caberá à narrativa resolver a ordenação do que é disperso e a integração daquilo que tem proveniência díspar (ou seja: entidades reais e entidades ficcionais)? Não será essa vocação integradora a via para se atingir um superior sentido narrativo, como objetivo último que motiva a enunciação de relatos? Um sentido que, na linha do pensamento de Paul Ricoeur, se distingue pela sua dimensão humana ou, num quadro de referência antropológica, como algo em que reconhecemos dimensão transcultural. E uma última interrogação, ainda a partir de Zelig: em que medida o poder representacional da imagem aprofunda (e também torna mais complexa) a tendência da narrativa para cultivar a oscilação entre o ficcional e o verídico, para integrar o que é disperso e para, desse modo, atingir o tal sentido narrativo que é a ultima ratio de todo o relato?

Serão perguntas retóricas? Se esta reflexão continuar, tratarei de resolver esta última interrogação - que, para que conste, nada tem de retórico.

\footnotetext{
${ }^{19}$ Ellen Garrison, que foi presidente da Women United for the United Nations, tinha 83 anos quando apareceu em Zelig e veio a falecer em 1995. Veja-se o obituário que sobre ela foi publicado no New York Times, em http://www.nytimes.com/1995/06/06/ obituaries/ellen-garrison-96-acted-in-film-zelig.html (acedido a 4.1.2016).
} 


\section{REFERÊNCIAS BIBLIOGRÁFICAS}

ABBOTT, H. P. (s.d.). "Narrativity", in The Living Handbook of Narratology (em http:// www.lhn.uni-hamburg.de/article/narrativity ; acedido a 7.1.2015).

BARTHES, R. (1966). "Introduction à l'analyse structurale du récit”, in Communications, 8, pp. 1-27.

BRUNER, J. (1991). "The narrative construction of reality", in Critical Inquiry, vol. 18, 1, pp. 1-21.

FELSKI, R. (2011). "Introduction", in New Literary History, 42: 2, pp. v-ix.

FLUDERNIK, M. (1996). Towards a 'Natural' Narratology. London and New York: Routledge.

PESSOA, F. (s.d.) "Dividiu Aristóteles a poesia em lírica, elegíaca, épica e dramática", em http://arquivopessoa.net/textos/4306 (acedido a 7.1.2016).

PRINCE, G. (2003). A Dictionary of Narratology. Revised edition. Lincoln and London: The Univ. of Nebraska Press.

PRINCE, G. (2005). "Narrativity", in D. Herman et alii (eds.), Routledge Encyclopedia of Narrative Theory. London and New York: Routledge, pp. 387-388.

QUEIRÓS, E. de (2009). Cartas Públicas. Edição de Ana Teresa Peixinho. Lisboa: Imprensa Nacional-Casa da Moeda.

REIS, C. (1989). "Les hétéronymes de Pessoa et la théorie bakhtinienne du dialogisme", in Manfred Pfister (ed.), Die Monernisierung des Ich. Passau: Wissenschaftsvrelag Richard Rothe, pp. 306-311.

REIS, C. (2015). Diálogos com José Saramago. 2. ${ }^{a}$ ed. Porto: Porto Editora.

REIS, C. $\left(2015^{\text {b }}\right)$. Pessoas de livro. Estudos sobre a personagem. Coimbra: Imprensa da Universidade de Coimbra.

REIS, C. e A. C. M. LOPES (2011). Dicionário de Narratologia. $7^{\mathrm{a}}$ ed. Coimbra: Almedina.

RICOEUR, P. (1983). Temps et récit. Paris: Seuil, tomo I.

RYAN, M.-L. (ed.) (2004). Narrative across Media. The Languages of Storytelling. Lincoln and London: Univ. of Nebraska Press.

RYAN, M.-L. (2006). Avatars of Story. Minneapolis and London: Univ. of Minnesota Press. 
RYAN, M.-L. e J.-N. THON (eds.) (2014). Storyworlds across Media. Toward a MediaConscious Narratology. Lincoln and London: Univ. of Nebraska Press.

SARAmAgO, J. (1990). "História e ficção", in Jornal de Letras, Artes e Ideias, 6 de março de 1990, pp. 17-19.

VILA MAIOR, D. (1994). Fernando Pessoa: heteronímia e dialogismo. Coimbra: Almedina.

WHITE, H. (1978). Tropics of Discourse. Essays in Cultural Criticism. Baltimore: The Johns Hopkins University Press. 


\section{ANÁlISE PRAGMÁTICA DA NARRATIVA: TEORIA DA NARRATIVA COMO TEORIA DA AÇÃO COMUNICATIVA}

No cotidiano de nossas vidas entramos e saímos constantemente no espaço das mídias impressas, eletrônicas e digitais, e nelas nos abastecemos. A mídia nos oferece pontos de referência, pontos de parada, pontos para olhar, se engajar e desengajar (Silverstone, 1999). A configuração de uma narrativa pública hoje é uma prática viva, transmidiática e intertextual (Scolari, 2009). Cada um de nós constrói seus próprios significados a partir de fragmentos de informações extraídos do fluxo midiático, através dos quais procuramos compreender nossas vidas. Essa cultura midiática e digital substituiu a sociabilidade tradicional, transformou-se em uma nova textura geral da experiência (Berlin, 1997) ou uma mundanidade mediada (Thompson, 1998). Nesse caleidoscópico fluxo e refluxo de socialização travam-se as batalhas discursivas pela posse dos significados, representações e senso comum. Na cultura da convergência (Jenkins, 2006), as narrativas públicas se configuram através da intersecção de uma multiplicidade de fontes e plataformas: cada fragmento acrescentado distende a narrativa para trás, para adiante ou para os lados, reatualiza a história deixando os relatos em um permanente estado de suspensão. 
Essa realidade nova sugere procedimentos de análise da narrativa mais dinâmicos que aqueles fornecidos pela linguística ou a teoria literária. O presente ensaio propõe que a narrativa seja compreendida como uma ação, cujo protagonismo, voz e perspetiva dos sujeitos narrador e destinatário na coconstrução do sentido sejam incorporados à análise. Até recentemente, a análise da narrativa concentrava-se no enunciado, no relato enquanto um produto acabado possuidor per se de um sentido autônomo. O foco se centrava na descoberta de estruturas recorrentes da narrativa que revelassem sua organicidade interna como um sistema fechado sobre si mesmo, com moto próprio: uma totalidade integral que agregava descrições de ações em um transcorrer sucessivo rumo a um desfecho. Categorias como encadeamento, sequência, composição, duração, ritmo, função e outras desempenhavam um papel fundamental nas análises. O importante era desvelar as constantes internas que compunham um modelo universal da intriga. Esse modelo de análise imanentista, inspirado no estruturalismo - episteme hegemônica na segunda metade do século passado - revelou-se por si mesmo insuficiente para compreender a dinâmica das narrativas na sociedade moderna. O esgotamento da narratologia estruturalista suscitou a necessidade de instrumentos capazes de capturar a comunicação narrativa. Esses instrumentos já estavam se consolidando bem antes do advento das mídias digitais. A dinâmica das novas modalidades apenas tornou o modelo imanentista ainda mais obsoleto.

É no bojo das alternativas epistemológicas trazidas pelo linguistic turn que uma narratologia crítica brotou. As inspirações vieram das teorias dos filósofos da linguagem H. P. Grice (1957; 1969), J. H. Austin (1962), J. R. Searle (1998; 2002; 2002a), e outros. E se abasteceram nas sistematizações da pragmática, no final do século passado (Reyes, 1994; van Dijk, 1987 e 2000; Vidal, 2002). Aqui, não posso recuperar as variadas proposições do linguistic turn nem as 
contribuições da pragmática. ${ }^{20}$ No presente ensaio, não ofereço uma sistematização teórico-metodológica acabada de um novo caminho epistemológico. Essa tarefa exigirá maior maturação intelectual. Há, aqui, apenas um esboço conceitual e metodológico preliminar que sugere interpretar as narrativas como atos de fala dinâmicos e circunstanciais, não como produtos fechados sobre si mesmos. Proponhome esboçar formulações preliminares de uma narratologia crítica, ainda nascente, que parece representar uma ruptura radical com os modelos anteriores de análise. Não tenho a pretensão de criar uma nova narratologia, obviamente. Até porque a maioria das ideias aqui ensaiadas são importadas de teorias desenvolvidas em outras áreas do conhecimento. Apenas tento produzir a síntese de um projeto de interpretação de narrativas que parece promissor. Pretendo somente sugerir um caminho alternativo a fim de que a narratologia alcance um status mais antropológico, para além dos restritos limites da linguística e da teoria literária.

No projeto de uma narratologia crítica aqui esboçado, sigo em parte a teoria pragmática dos atos de fala, segundo a qual os atos enunciativos "são operações em contexto, como funções de contexto em contexto" (Levinson, 2007:352, grifo meu), entendidos estes como um conjunto de proposições que descrevem crenças, conhecimentos, compromissos e ideologias dos participantes. Quando uma narrativa é enunciada, acontecem mais coisas que apenas a expressão do seu significado, pois o conjunto de fundo também é alterado. A contribuição que uma enunciação fornece à mudança do contexto é a força ilocucionária, ou potência do ato de fala. A tese de Levinson, com a qual concordo, é que essa força é irredutível à questões de conteúdo, verdade ou falsidade do enunciado, pois constitui um aspecto do significado que não pode ser capturado pela semântica veridicional.

\footnotetext{
${ }^{20}$ Aos interessados, remeto à Parte 1 do meu livro Notícias do fantástico (Motta, 2006). E particularmente à coletânea de ensaios reunidos sob o título La búsqueda del significado, de L. M. Valdés Villanueva (2000).
} 
"O lugar próprio da força ilocucionária é o domínio da ação, e as técnicas adequadas para a análise devem ser encontradas na teoria da ação, não na teoria do significado", uma maneira inteiramente pragmática de lidar com a força ilocucionária (Levinson, 2007:312, grifo dele).

Sigo também a hermenêutica crítica de Paul Ricoeur (1983: 46:7), para quem o discurso é um evento realizado no presente, que remete ao seu locutor mediante um conjunto complexo de indicadores. O caráter do evento vincula-se, assim, à pessoa que fala. Mais ainda, o evento consiste no fato de alguém falar, tomar a palavra para expressar-se a respeito de algo: refere-se a um mundo que pretende descrever ou representar. Neste sentido, o ato de fala é a vinda à linguagem de um mundo mediante o discurso, e não somente um mundo, mas também o outro, outra pessoa, um interlocutor ao qual o locutor se dirige. É da tensão entre estes dois polos que surge a produção do discurso como obra (o sentido). O que a hermenêutica deve compreender, diz Ricoeur, "não é o evento, na medida em que é fugidio, mas sua significação que permanece". ${ }^{21}$ A obra traz uma proposição de mundo "que não se encontra atrás do texto como uma espécie de intenção oculta, mas diante dele como aquilo que a obra desvenda, descobre, revela" (1983:58).

Em trabalho anterior, sugeri que a narratologia deveria deslocar-se da teoria literária para tornar-se um procedimento multidisciplinar de caráter cultural e cognitivo, envolvendo a interpretação de mitos, ideologias e os valores canônicos e políticos da sociedade (Motta, 2013). O presente ensaio pretende avançar nesse rumo, até porque nunca antes a rotina de vida das sociedades foi tão permeada por uma complexa enxurrada de narrativas como hoje. Cognitivamente, elas configuram o sentido ordinário da vida. Quotidianamente, somos

\footnotetext{
${ }^{21}$ Ricoeur (1983:56) ressalta: o que deve ser interpretado no texto é uma proposição de mundo, "um mundo tal como posso habitá-lo para nele projetar um de meus possíveis mais próprios". O mundo do texto, próprio e único deste texto.
} 
inundados por biografias, mini-contos, breves romances, reportagens, filmes, documentários, telenovelas, canções, videoclipes, videogames, histórias em quadrinhos, desenhos animados, comerciais de TV, anedotas, diários de vida, breves relatos do facebook, whatsapp, Instagram e outras redes sociais digitais. Através das novas tecnologias, o público tomou para si um protagonismo maior do contar. Nunca antes nossas estórias foram tão compartidas, tornando mais densa e complexa a rede coletiva de narrativas públicas. Nunca antes fomos tão narradores, e simultaneamente destinatários, de nossas próprias aventuras. A vida contemporânea se desenvolve sob um mar de relatos híbridos e fragmentados que se emendam uns aos outros, entretecendo uma teia virtual de narrativas na qual estamos todos enredados. Provenientes de diferentes plataformas, descontínuos e dispersos, fáticos ou fictícios, locais ou universais, comerciais ou públicos, informativos ou puro entretenimento, poucos desses relatos alcançam constituir-se peças literárias. São erráticos, efêmeros e caleidoscópicos. Mal ou bem, entretanto, os relatos públicos configuram as narrativas multimidiáticas ou transmidiáticas da modernidade e constituem o mar de híbridas histórias que confirmam a hegemônica cultura da convergência.

\section{Teoria da narrativa como uma teoria da ação}

A tese de Paul Ricoeur no tomo I de seu reconhecido ensaio Tempo e Narrativa (1994) é que a operação de configuração da tessitura de uma intriga extrai sua inteligibilidade de sua faculdade de mediação entre a prefiguração (processo de produção) e a refiguração (processo de recepção). Ou seja, a obra eleva-se do fundo opaco do viver e agir para ser dada por um autor à um leitor que a recebe e, assim, muda seu agir. A hermenêutica ricoeuriana, dessa forma, preocupa-se em reconstruir o arco inteiro das operações da experiência: a obra media 
entre autores e leitores. O desafio, segundo ele, é a reconstituição do processo concreto pelo qual a configuração (mimese II) faz a mediação entre a prefiguração (mimese I) e sua refiguração (mimese III). Assim, o autor subordina a questão do encadeamento narrativo à determinação da função mediadora da intriga: ela media entre o momento da experiência prática que a precede e o estágio da experiência receptora que a sucede. ${ }^{22}$

Se é verdade que a intriga é uma imitação das ações humanas, quem a compõe parte de uma pré-compreensão do mundo, suas estruturas inteligíveis, simbólicas e temporais; e sua competência para articular a representação das ações em uma trama. Mais importante ainda, diz Ricoeur, é observar que quem compõe age com certas motivações a fim de produzir certos efeitos. Torna-se então importante, observa ele, identificar o agente e seus motivos. Ademais, prossegue, agir é sempre agir 'com' outros: "a interação pode assumir a forma de cooperação, de competição ou luta" (Ricoeur, 1994:89). A compreensão narrativa deve, pois, ser estabelecida entre a teoria narrativa e a teoria da ação: "Compreender uma história é compreender ao mesmo tempo a linguagem do 'fazer' e a tradição cultural da qual procede a tipologia das intrigas" (Ricoeur, 1994:91).

Pelo lado da recepção, observa Ricoeur, "a narrativa tem seu sentido pleno quando é restituída ao tempo do agir e do padecer", no momento em que é lida. A recepção, segundo ele, "marca a intersecção entre o mundo do texto e o do leitor". O mesmo 'pano de fundo'

\footnotetext{
${ }^{22}$ Ricoeur retoma este assunto no capítulo 3, tomo II, de Tempo e Narrativa (1995) onde reconhece a necessidade do deslocamento de atenção do enunciado para o ato de enunciação, passando para primeiro plano os jogos entre a inclusão e exclusão de conteúdos, a ideologia em última instância. Ao final deste capítulo, o autor explica que as noções de voz e perspetiva narrativa precisam ser incorporadas à análise da composição narrativa. Isso se faz, diz ele, vinculando-as às categorias de narrador e personagem. Ricoeur admite que a questão do ponto de vista diz respeito à composição, mas o problema da voz narrativa é uma questão de comunicação na medida em que ela se dirige a um leitor (Ricoeur, 1995:163).
} 
da cultura, de histórias vividas e (ainda) não contadas, imbricadas umas às outras, sobre as quais as novas histórias emergem, opera aqui: "Narrar, seguir, compreender histórias é só a 'continuidade' dessas histórias não ditas" (Ricoeur, 1994:116). No ato de ler, diz ele, o leitor reconfigura e conclui a obra: "É o leitor, quase abandonado pela obra, que carrega sozinho o peso da tessitura da intriga" (Ricoeur, 1994:118). O ato de leitura, conclui, é "o último vetor da configuração do mundo da ação sob o signo da intriga" (Ricoeur, 1994:118). Não preciso prosseguir com a rica argumentação de Paul Ricoeur a respeito da narrativa como uma teoria da ação comunicativa. Ficou evidente que configurar e refigurar uma intriga são ações protagonizadas por sujeitos vivos e ativos, são performances linguísticas movidas por motivações e intenções recíprocas. As breves citações acima são suficientes para indicar uma total reviravolta proposta por ele (e outros autores) na teoria e análise da narrativa, pois a teoria da narrativa torna-se uma teoria da ação comunicativa. É nessa direção que procederei rumo a uma análise pragmática, a ela anexando o adjetivo crítica pelo seu potencial de contextualizar a interpretação narrativa.

É importante trazer a palavra avaliadora de Paul Ricoeur a respeito da narrativa como ato de fala por causa da respeitabilidade dele no campo da narratologia. Entretanto, Ricoeur não é uma referência fundamental na teoria dos atos de fala, que provém da filosofia da linguagem. Até pouco tempo atrás, os filósofos e linguistas estavam preocupados com a competência linguística de cada frase ou texto, e sua correspondência com a verdade. A virada aconteceu em meados do século passado, quando alguns filósofos explicaram que falar não é somente emitir frases para comunicar informações: a fala realiza coisas para além dos conteúdos proposicionais, e o mais importante talvez não seja a sentença proferida, e sim o que ela obtém como seu efeito independente de sua condição de verdade. Toda vez que falamos, realizamos 
um ato de fala: faço uma pergunta, dou uma ordem, explico ou predigo algo, etc. ${ }^{23}$

Ou seja, para além dos conteúdos, há uma força implícita na fala, que o filósofo J. Austin (1962) chamou de ilocução. Os potenciais efeitos desses atos junto aos receptores, ele chamou de atos perlocutivos. Os atos ilocutivos detém quase sempre uma intenção realizativa: pretendem algo. A mente do sujeito falante impõe intencionalidade aos sons, imagens ou textos, conferindo a eles um significado relacionado à realidade. ${ }^{24}$ Para J. Searle $(1998,127)$, seguidor de Austin, o significado é uma forma de intencionalidade derivada: a intencionalidade intrínseca do pensamento do falante se transfere às palavras e frases pronunciadas. Mas, a intenção de comunicar não coincide sempre com a intenção de significar. Comunicar é obter que o outro reconheça a minha intenção de produzir certo efeito, obter que o outro capte o meu significado.

Se transplantamos essas reflexões da filosofia da linguagem para a narratologia, torna-se relevante redefinir a narração (ou enunciação narrativa) como um ato de fala comunicativo porque os relatos sempre implicam em efeitos não necessariamente referenciados no texto: as narrativas são por natureza irônicas, trágicas, cômicas,

\footnotetext{
${ }^{23}$ Segundo J. Searle (1979), todas as enunciações caem dentro de cinco categorias básicas: elas podem ser assertivas (descrevem como as coisas são), diretivas (levam as pessoas a realizar coisas), compromissivas (comprometem as pessoas), expressivas (expressam sentimentos) ou declarativas (provocam mudanças no mundo) (Searle, 1979). Essas mesmas cinco categorias são resumidas em outras obras do autor. Ver Searle, 2001:133-135. É discutível se todas proposições cabem dentro de apenas cinco categorias.

${ }^{24}$ Autores de variadas áreas sociais desenvolveram posteriormente a teoria da ação. No que concerne à comunicação, J. B. Thompson (1998), por exemplo, critica J. Austin e seus seguidores porque eles não conduziram suas reflexões para uma contextualização social dos atos de fala. Por isso, as considerações deles tenderiam a ser um tanto formais e abstratas, divorciadas das circunstâncias de poder nas quais os indivíduos e instituições utilizam a linguagem no dia a dia. Para Thompson, nós podemos retomar as observações de Austin somente se desenvolvermos uma teoria social substantiva da ação e dos tipos de poder em que ela se baseia. Concordo em parte com essas observações, e sigo em uma direção semelhante na proposta apresentada neste ensaio.
} 
etc. Cada uma delas quer produzir determinado efeito de sentido, muitas vezes apenas subentendido. Assim, precisamos partir de uma definição de comunicação que descreva adequadamente o processo de narração como um ato de fala com os seus possíveis efeitos de sentido. Encontro uma definição adequada em Levinson (2007:19), que diz:

\begin{abstract}
A comunicação consiste no fato de o emissor intentar fazer com que o receptor pense ou faça alguma coisa, simplesmente fazendo o receptor reconhecer que o emissor está tentando causar tal pensamento ou a ação. Portanto, a comunicação é um tipo complexo de intenção, que é realizada ou satisfeita simplesmente por ser reconhecida. No processo de comunicação, a intenção comunicativa do emissor torna-se conhecimento mútuo para o emissor (F) e o receptor $(\mathrm{O})$, isto é, $\mathrm{F}$ sabe que $\mathrm{O}$ sabe que $\mathrm{F}$ sabe que $\mathrm{O}$ sabe (e assim $a d$ infinitum) que $\mathrm{F}$ tem esta intenção específica.
\end{abstract}

Os atos de comunicação (incluindo a narração) são regidos por acordos implícitos entre os interlocutores que tornam possível entender o significado literal, mas também inferir outras significações a partir da força ilocutiva do enunciado. Esse acordo virtual revela a intenção de quem fala e sugere uma interpretação cooperativa de quem lê, vê ou escuta uma história. Ajustamos automaticamente esses acordos em nossas relações cotidianas com os nossos diversos interlocutores, readaptando continuamente as nossas expectativas e as deles, tornando cada fala um ato de comunicação singular e circunstancial. Assim, o que se diz não é necessariamente o que se comunica em cada situação: há diversas implicaturas e pressuposições insinuadas, gestos, dêiticos, etc. Os dêiticos (sutis referências de espaço, tempo, hierarquia social, etc.) são particularmente relevantes porque revelam a importância do contexto comunicativo 
para a compreensão dos significados. Conforme observa Levinson (2007), os dêiticos gramaticalizam traços do contexto na enunciação e revelam como a interpretação das narrações depende da consideração do ambiente da enunciação (voltarei à questão dos dêiticos adiante).

Por sua natureza criativa, a enunciação narrativa é rica em implicaturas e pressuposições que direcionam a fala rumo a inúmeros efeitos de sentido (espera, suspense, susto, sofrimento, riso, assombro, medo, etc.). Elas estão presentes na própria estruturação dramática do texto, na criação do suspense, no amplo uso de figuras de linguagem (metáforas, ironias, hipérboles), na intertextualidade, na ênfase e hierarquia lexicais que põem a comunicação narrativa em funcionamento. O uso intencional desses recursos de linguagem constitui a dimensão pragmática da comunicação narrativa: significados virtuais que decorrem das intencionalidades do sujeito narrador e das interpretações do sujeito receptor (os atos ilocutivo e perlocutivo). As intenções do autor e sua realização (ou não) no ato de recepção são os dois extremos de uma atividade de comunicação em que o texto funciona como o nexo entre os interlocutores. Ou seja, a comunicação narrativa visa provocar mudanças no estado de ânimo das pessoas, podendo eles serem positivos quando favorecem a auto-afirmação (amor, compreensão, compaixão), ou negativos quando a desfavorecem (medo, ira, inveja) (Motta, 2006). Embora brevemente, creio ter enumerado até aqui argumentos suficientes para justificar que o relato não é mera representação da vida, mas um ato comunicativo impregnado de força ilocutiva: realiza sempre uma interlocução criativa. Neste rumo pragmático, a teoria da narrativa distancia-se da teoria literária para tornar-se uma teoria da ação comunicativa. Seu uso deixa de atender apenas à crítica literária ou estética para tornar-se uma metodologia crítica dos atos narrativos. 


\section{A dimensão crítica da pragmática}

A disciplina da pragmática é relativamente recente entre as teorias da linguagem. Sobre a pragmática narrativa, não há literatura específica. A própria teoria dos atos de fala só há pouco saiu do campo da filosofia e começou a se constituir em um projeto metodológico mais consistente. Não há sequer uma definição precisa nem delimitação do alcance da pragmática (Levinson, 2007; Dascal, 2006). ${ }^{25}$ Ela surgiu como uma disciplina um tanto marginal, que se ocuparia das coisas que a semântica e outras disciplinas linguísticas desprezavam (as pressuposições, subentendidos, ironias, etc.), a chamada "cesta de lixo" de Gottlob Frege, ou resíduos de outras teorias (Reyes, 1994; Dascal, 2006). O interesse atual pela pragmática decorreu da percepção geral de que a língua é utilizada para comunicar, e a comunicação é mais que um conteúdo proposicional. A partir daí, linguistas, filósofos e outros se deram conta da necessidade de considerar o contexto dinâmico do uso da linguagem, a performance e motivações (intencionalidades) dos sujeitos interlocutores. ${ }^{26}$

Há consenso que a pragmática refere-se ao estudo do uso que os sujeitos interlocutores fazem da linguagem em um determinado contexto comunicativo (Reyes, 1994). Das condições que determinam o emprego de um enunciado concreto por parte de um falante concreto em uma situação de comunicação concreta, tanto quanto a

\footnotetext{
${ }^{25}$ Vidal (2002) define pragmática como uma disciplina que toma em consideração os fatores extralinguísticos que determinam o uso da linguagem. Reyes (1994) a nomeia como uma disciplina linguística que estuda como os seres falantes interpretamos enunciados em contexto. Dascal (2006) diz que a pragmática é o estudo do uso dos meios linguísticos (ou outros) por meio dos quais um falante transmite as suas intenções comunicativas, e um ouvinte as reconhece. Levinson (2007) define a pragmática como o estudo das relações entre língua e contexto que são gramaticalizadas ou codificadas na estrutura da língua: o estudo apenas dos aspectos da relação entre a língua e o contexto que são relevantes para a elaboração das gramáticas. Van Dijk (2000) contribui com uma teoria cognitiva da pragmática, cuja razão fundamental é estabelecer relações entre os enunciados (a linguística) e a interação (as ciências sociais).
}

${ }^{26}$ Ver Levinson, 2007:42-56. 
interpretação de parte de um destinatário (Vidal, 2002). Isso torna a pragmática um procedimento empírico que estuda como os sujeitos interlocutores usam e interpretam enunciados em determinado contexto de comunicação, o que revela o potencial dela para tornar-se uma teoria crítica e nos anima a perseguir um projeto teórico e metodológico que pode revelar-se promissor para a narratologia.

Transplantar as propostas da pragmática para um projeto de narratologia é certamente uma atitude problemática que suscita inúmeros desafios não tratados aqui. Porém, nada me impede de ousar, reconhecendo a necessidade de refinamentos posteriores. Me dedicarei em seguida a dois aspectos particulares da pragmática que requerem uma atenção imediata devido ao seu peso metodológico em uma narratologia crítica: 1) o protagonismo dos atores; 2) o contexto comunicativo e os dêiticos. Antes, porém, uma advertência sobre o uso do adjetivo 'crítica' na análise que proponho: a meu ver, a possibilidade de incorporar o contexto nos procedimentos de análise consolida uma pragmática expandida como uma teoria crítica. ${ }^{27} \mathrm{O}$ adjetivo crítica tem aqui um valor particular, pois não significa formar juízos de valor, mas sim assumir uma proficiência metodológica a fim de incorporar de maneira rigorosa e fundamentada o papel dos interlocutores e os elementos do contexto comunicativo e cultural nos próprios procedimentos, o que dá à análise da comunicação narrativa um alcance social e histórico. ${ }^{28}$

\footnotetext{
${ }^{27}$ Crítica, observa Paul Ricoeur (1983:21) citando o famoso adágio de F. Scheleiermacher, é o "propósito de lutar contra a não-compreensão: há hermenêutica onde houver não compreensão; romântico, é o intuito de compreender um autor tão bem, e mesmo melhor do que ele mesmo se compreendeu".

${ }^{28}$ Em sua origem, a análise crítica provém do marxismo. Diversos autores fornecem elementos estimulantes que podem, com precauções, serem transportados para um projeto de análise crítica das narrativas. Entre os marxistas, destaco duas obras do crítico literário inglês Terry Eagleton: Marxism and literary criticism (2002) e Criticism E Ideology (2006), ambos originais publicados em 1976. Entre os não-marxistas, destaco o crítico literário canadense Northrop Frye em seu The critical path (1971), e a segunda parte de Interpretação e ideologias, de Paul Ricoeur (1983), onde ele discute sua hermenêutica crítica.
} 


\section{Protagonismo de narradores e destinatários}

A primeira contribuição relevante da pragmática para o projeto de uma narratologia crítica é levar em conta o protagonismo dos sujeitos interlocutores - narrador e destinatário - nos procedimentos de análise. Mais que uma questão de identidade, é necessário que o analista conheça os papéis sociais dos sujeitos, suas intenções comunicativas e as relações de força entre eles (posição social, hierarquia, diferença de gênero, etc.). A pragmática chama o sujeito enunciador de emissor, mas na teoria narrativa é mais adequado denominá-lo narrador, termo que adotarei por conferir a essa figura um ativo protagonismo. Diferente da teoria literária clássica, na pragmática, o narrador é um sujeito real que atua no momento em que emite a sua narração, com seus valores, vontades históricas e uma performance comunicativa concreta. ${ }^{29}$ Da mesma maneira, o destinatário é também um sujeito (ou sujeitos) ativo que se engaja no ato comunicativo por vontade própria, com sua memória, seus valores e ideologias. O destaque, portanto, é a performance dos sujeitos interlocutores. O que move ambos é a vontade coletiva de fazer sentido. Na comunicação narrativa, alguém quer utilizar as técnicas de enunciação dramática para envolver o destinatário, ainda que essa vontade se realize às vezes cooperativamente e outras vezes conflituosamente. Mas o destinatário também participa do ato comunicativo por vontade própria.

O narrador é quem inicia a atividade de contar conforme sua vontade e manipula a linguagem a fim de obter a realização de suas intenções comunicativas. Mas, não é só ele quem toma a iniciativa. Como diz Bakhtin (2003), o ouvinte tem igualmente desejos, se engaja no processo comunicativo com interesses próprios, e tem posturas ativas de resposta: pode não estar de acordo, precisa completar lacunas de sentido,

\footnotetext{
${ }^{29} \mathrm{Na}$ teoria literária narrador e destinatário têm uma especificidade ontológica, um estatuto ficcional, primordialmente textual, diferente do autor, leitor ou audiência concretos. O narrador é o enunciador do discurso, que pode ou não corresponder a um sujeito real (Reis e Lopes, 2007:257-8).
} 
se prepara para uma outra ação, etc. A simples compreensão de um discurso, diz o autor, tem sempre algum grau de resposta, ainda que ela só venha a ocorrer tempos depois. Ambos sujeitos estão imbuídos do desejo de produzir sentidos e, neste sentido, são protagonistas do ato comunicativo. A correlação de forças entre eles pode ser simétrica ou assimétrica, hierárquica ou igualitária, predominando a cooperação ou o conflito. Identificar os lugares que os sujeitos interlocutores ocupam hierarquicamente, seus papéis sociais, suas motivações, a correlação de poder entre eles no ato narrativo é o primeiro passo que um analista precisa dar ao se propor uma interpretação crítica.

Dissemos acima que a comunicação só se completa quando o destinatário reconhece as intenções do falante. Isso ocorre também na comunicação narrativa. Quando alguém escolhe contar, pretende seduzir, envolver, fazer rir ou chorar, impactar o outro de alguma forma. O significado, como diz Searle (2001:127-130) é uma forma de intencionalidade derivada:

\begin{abstract}
A intencionalidade original do pensamento de um falante se transfere às suas palavras e textos, [...] que possuem uma intencionalidade derivada do pensamento do falante. Elas não possuem apenas o significado linguístico convencional, mas também o significado que o falante a elas quis dar. [...] Quando nos comunicamos com alguém, logramos que esse alguém reconheça nossa intenção de produzir compreensão. A comunicação é peculiar entre as ações humanas no sentido que conseguimos produzir o efeito pretendido no ouvinte ao lograr que ele reconheça a intenção de produzir esse mesmo efeito ${ }^{30}$.
\end{abstract}

Toda narração é um ato carregado de intenções: o narrador sempre realiza algo além de proferir uma história literal: ele não só 'convida'

30 Tradução livre do autor. 
alguém a ouvi-lo, mas também busca seduzir esse alguém, modificar seu espírito, envolvê-lo e, principalmente, fazê-lo compreender como o mundo funciona.$^{31}$ As narrativas são um meio de sensibilizar e mobilizar pessoas, obter consenso, criar o senso comum (Bruner, 1998). Neste sentido, a construção de uma intriga (fática ou fictícia) é o ato de organizar a realidade de uma maneira coerente e compreensível a fim de obter a aquiescência e/ou efeitos junto aos interlocutores. Assim, o analista pragmático precisa identificar no texto pistas e traços que indutivamente lhe permitam chegar até as intenções de um narrador diante de um (ou vários) destinatários.

Já dissemos que o envolvimento entre os sujeitos interlocutores pode ocorrer de maneira cooperativa ou conflituosa. Em si, a relação de interlocução é sempre solidária na medida que, no ato comunicativo, um sujeito valida a fala do outro, e vice-versa (independente da concordância sobre o conteúdo). Na comunicação face a face, há turnos de fala, permutas flexíveis e incessantes adaptações. Na comunicação mediada, há pouca ou nenhuma interação, embora a interlocução sempre esteja presente de maneira mais ou menos tangível. O mundo da vida costuma ser desigual, há sempre assimetrias sociais e culturais (antagonismos de classe, gênero, profissão, religião, hierarquia política, institucional ou familiar, etc.) que levam à diferentes pontos de vista sobre os acontecimentos. Há sempre forças antagônicas operando e a relação de confronto é mais usual. O significado resulta de uma disputa (quase sempre velada), mais que de cooperação (no sentido do conteúdo em questão).

Torna-se então útil compreender as narrativas como instrumentos de disputas, estratégias de argumentação, convencimento e cooptação.

\footnotetext{
${ }^{31}$ Searle (2001:81) explica assim o conceito de intencionalidade: "Meus estados subjetivos me relacionam com o resto do mundo e o nome geral dessa relação é intencionalidade. Esses estados subjetivos incluem crenças e desejos, intenções e percepções, assim como amores e ódios, temores e esperanças. Intencionalidade, repitamos, é o termo geral para as diversas formas mediante as quais a mente pode ser dirigida à - ou referir-se à - objetos e estados de coisas no mundo". (Livre tradução do autor).
} 
Nessa perspetiva, as narrativas passam a serem vistas como instrumentos de naturalização do mundo e de legitimação de papéis. Elas podem ser instrumentos de imposição e dominação, embora talvez seja mais usual situações onde elas funcionam como objetos de disputa e barganha pelas representações do mundo. Como ensina Foucault (2010), o poder flutua, vai e volta, inverte e reverte, está sempre em disputa e renegociação. Pessoas, grupos e classes estão sempre em disputa por narrativas hegemônicas. Há convergência, divergência e permuta constante por interpretações mais legítimas. Conforme observa Kerbrat-Orecchioni (2006:74), a interlocução é um processo dinâmico no qual nada é determinado de uma vez por todas, pois o tabuleiro se modifica constantemente:

\begin{abstract}
As trocas comunicativas são o lugar de batalhas permanentes pela alta posição (batalhas mais ou menos discretas ou alardeadas, corteses ou brutais), quer se trate de trocas institucionalmente desiguais, nas quais o jogo dos taxemas pode infletir, e até mesmo inverter (pelo menos provisoriamente) a relação de lugares inicial; ou de trocas, em princípio iguais, nas quais sua ação pode constituir uma relação de dominação a priori inexistente.
\end{abstract}

A disputa por narrativas mais 'verdadeiras' e mais 'naturais' é a força que move os sujeitos narradores e destinatários no mundo da vida. Que razão motiva alguém a organizar a realidade narrativamente? O que pretende alguém ao contar uma história? Que efeitos de sentido pretende produzir no destinatário? Nenhuma narrativa é ingênua, toda narrativa realiza algo, realiza jogos de linguagem e de poder: atrair, conquistar, excitar, motivar, cooptar, mobilizar, etc. Por isso, toda narrativa é argumentativa, pois é dotada de intencionalidade, orienta-se para mudar espíritos, realizar determinado efeito de sentido. Se alguém escolhe organizar narrativamente seu discurso, 
é porque sabe, intuitiva ou racionalmente, que o relato é a melhor estratégia para realizar suas intenções comunicativas. Todo narrador conhece o potencial de sedução e envolvimento que a narrativa detém. Narrativas são dispositivos argumentativos, representam o uso consciente ou inconsciente para criar uma cooperação induzida. $\mathrm{O}$ ato de argumentar e orientar o discurso no sentido de determinadas conclusões constitui o ato linguístico fundamental, pois a todo e qualquer discurso subjaz uma ideologia (Kock, 2002). A argumentação constitui a atividade estruturante de qualquer discurso, e particularmente das narrativas. É através da análise pragmática e retórica que se conhecerá o jogo de poder e as ideologias, dos quais a narrativa é uma parte tangível. Como nenhum ato narrativo se reproduz duas vezes, resta ao analista identificar no texto os traços e pistas que revelem as intenções comunicativas e sua realização (ou não). Isso torna a teoria narrativa uma teoria da argumentação, e sua interpretação, uma análise da retórica argumentativa que desvelará os ardis e artimanhas argumentativos. Os jogos de poder, enfim.

\section{Contexto e dêiticos da situação comunicativa}

A segunda contribuição relevante da abordagem pragmática para o projeto de uma narratologia crítica é a incorporação do contexto aos procedimentos de análise. É a incorporação de determinantes contextuais que dá à análise um caráter crítico e a difere de outras metodologias. Os autores acima citados enfatizam a importância que o contexto e as circunstâncias da situação de comunicação (os fatores extralinguísticos) têm no processo de construção das representações sociais. Cada ato de fala narrativo ocorre em um ambiente psicossocial específico, que sempre contingencia tal ato.

Argumentando que a hermenêutica só se torna relevante devido à múltipla significação dos textos, e que o intérprete precisa ter 
sensibilidade ao contexto, Ricoeur (1983:19) observa: "A sensibilidade ao contexto é o complemento necessário, e a contrapartida inelutável da polissemia". O manejo do contexto, prossegue ele, põe em jogo o discernimento da permuta concreta de mensagens entre interlocutores precisos, atividade propriamente dita da interpretação: "reconhecer qual a mensagem relativamente unívoca o locutor construiu apoiado na base polissêmica". Identificar essa intenção de unicidade na recepção das mensagens é "o primeiro e mais elementar trabalho da interpretação".

Gostaria de me deter sobre os fatores de contingenciamento que atuam de maneira decisiva, em maior ou menor grau, sobre a configuração das histórias. A partir de uma breve revisão da literatura, farei ao final uma sugestão para a incorporação desses fatores aos procedimentos de análise através da consideração dos ciclos dêiticos. O contexto é tão importante para a passagem do significado da sentença ao significado da enunciação que o filósofo Max Black propôs certa vez que a nascente disciplina se chamasse contextics a fim de dar conta de todos os aspectos do contexto relevantes para a linguagem. (Dascal, 2007:561). A questão metodológica da incorporação do contexto na análise da narrativa não é entretanto um problema fácil. É preciso primeiro delimitar o quê é o contexto, seus limites, e qual a sua relevância para cada ato de fala. Isso abre um amplo leque de possíveis fatores pertinentes. O que é ou não é relevante para os participantes em cada ato discursivo? Até onde se expande o entorno que intervém no processo comunicativo? Qual é a força relativa de cada um dos fatores? ${ }^{32}$ Mais complicado ainda é

\footnotetext{
${ }^{32}$ Não se trata aqui de uma questão de variáveis dependentes ou independentes, como certa ciência social positivista professa. A medida exata da interferência de cada fator do contexto sobre a coconstrução compartilhada das representações sociais é uma questão cognitiva que dificilmente poderá ser delimitada com precisão, pois o reconhecimento recíproco dos parceiros do ato interlocutivo se processa através de sucessivas hipóteses-testes: em uma situação concreta o que o locutor faz é avançar uma hipótese para seu interlocutor esperando que ele interprete suas motivações. Não faltam, entretanto, inúmeras situações de mal-entendidos. No entanto, algum tipo de interferência do contexto precisa ser assumida pelo analista no momento da interpretação. Quanto mais seguro e maior domínio ele retiver do contexto, mais convincente será a sua interpretação.
} 
incorporar as relevâncias contextuais nos próprios procedimentos de análise, como veremos.

Para tornar a análise definitivamente crítica, sugiro observar os fatores extralinguísticos como instrumentos de um jogo de poder que se manifesta nos discursos narrativos de maneira argumentativa, conforme observei acima. Penso que uma correlação de forças proveniente do ambiente psicossocial está sempre condicionando cada ato narrativo, mesmo aqueles atos aparentemente despretensiosos, como a mãe que conta uma singela história de fadas ao seu filho pequeno ao anoitecer. Ao contar, a mãe não é totalmente despretensiosa: ela tem a intenção de acalmar e ninar sua cria. Há uma intencionalidade implícita no ato de contar. A narrativa da mãe realiza um ato performativo ao embalar a criança. O relato dela é um texto, mas é também uma atividade social que existe em par com outras formas semelhantes, e com elas se interrelaciona, conforme observa (Eagleton, 2006). Assim, não há ato de fala que não seja argumentativo, nem ato de fala que não carregue alguma carga ideológica. Uma reciprocidade de forças, de encantamento, empatia ou mútua compulsão, próprias de cada ação humana, move e condiciona sempre a configuração de qualquer narrativa. O relato é o resultado dessa recíproca volição. Embora a vontade de sentido não signifique sempre afinidade, como observei acima. Haverá divergência sempre que houver assimetria psicossocial.

Metodologicamente, como delimitar as forças que movem os atores e condicionam cada ato de fala? A resposta a essa pergunta não é fácil. Há na literatura variadas sugestões sobre a extensão do entorno a considerar. A maioria dos autores refere-se à identidade dos sujeitos interlocutores, ao conhecimento compartido por eles, à situação da comunicação (lugar e tempo), e suas circunstâncias sociais. Citando Corseriu (1967), Vidal (2002:30) enumera seis componentes não-linguísticos do contexto que, segundo ela, influem decisivamente: 1) contexto físico (coisas que estão à vista); 2) contexto 
empírico (o estado das coisas objetivas em um momento determinado); 3) contexto natural (totalidade de contextos empíricos possíveis); 4) contexto prático (a conjuntura particular objetiva e subjetiva onde ocorre a fala); 5) contexto histórico (circunstâncias históricas conhecidas pelos interlocutores); 6) contexto cultural (a tradição cultural da comunidade dos interlocutores). Segundo Vidal, só o primeiro seria um fator externo objetivamente descritível, os demais seriam componentes relacionais que geram conceitualizações subjetivas. Esses componentes são sugestivos ao circunscreverem limites. No entanto, parecem vagos, pouco claros, e sobrepostos.

Vidal oferece uma contribuição própria ao discorrer sobre a 'informação pragmática' compartida, segundo ela, o conjunto de conhecimentos, crenças e sentimentos dos interlocutores no momento da interlocução: uma "internalização da realidade objetiva". Citando van Dijk (1989), Vidal diz que a informação pragmática tem um caráter geral (conhecimento de mundo), situacional (percepções recíprocas durante a interlocução) e contextual (aquilo que deriva das expressões linguísticas dos discursos imediatamente precedentes), que na sua teoria da relevância Sperber e Wilson (1986) preferem chamar de "entorno cognitivo compartido" ao se referir às representações mentais compartilhadas. Vidal sugere que o termo 'entorno cognitivo' parece modesto demais para dar conta de toda a informação pragmática que se comparte, porque considera que as relações sociais influem pelo simples fato de ambos interlocutores fazerem parte de uma mesma comunidade social.

Dascal (2006), por sua vez, afirma que todos os textos são opacos e necessitam do contexto para serem interpretados. A função do contexto, diz ele, é fornecer pistas para a geração de hipóteses interpretativas, cuja validade deve ser interpretada à luz da informação referencial. Em princípio, continua ele, qualquer informação contextual pode ser relevante, e neste sentido, é impossível restringir o contexto a determinado conjunto de dados. Ele sugere dois tipos 
gerais de contexto, um metalinguístico (gênero, normas, situação comunicativa, etc.) e outro extralinguístico (universo de referência, conhecimento de fundo, crenças compartilhadas, hábitos e idiossincrasias do falante, etc). E apresenta um ilustrativo gráfico de pistas interpretativas (Dascal, 2006:195-199) que vão das estruturas linguísticas ao conhecimento de mundo compartilhado (cultura, ideologia). $\mathrm{O}$ autor sugere que o analista proceda a partir de pistas (clues) e dicas (cues). A interpretação das dicas seria um processo dedutivo, enquanto o das pistas seria indutivo.

\section{Deixais ampliada: a atualização do contexto nos significados}

Levinson (2007:65) apresenta uma alternativa instigante sobre a relação entre a língua e o contexto. Para ele, essa relação revela a importância da dêixis. É através da dêixis que "as línguas gramatilizam traços do contexto da enunciação", diz ele. O Dicionário de Linguística de Jean Dubois (1973:168) define a dêixis de maneira semelhante ao Dicionário de Retórica de A. Marchese e J. Forradellas (1998:92). Dêixis, segundo ambos dicionários, seriam as coordenadas espaço-temporais da enunciação: o sujeito refere o seu enunciado ao momento da enunciação, aos participantes da comunicação e ao lugar em que o enunciado se produz. As referências a essa situação formariam a dêixis, um modo particular de atualização que utilizaria o gesto (dêixis gestual) ou termos da língua chamados dêiticos verbais. Apresentando uma classificação restrita da dêixis, ambos dicionários citam U. Weinreich, que propõe quatro influentes fatores da situação, organizados a partir da pessoa que fala: 1) a origem do discurso (o eu) e o interlocutor (o tu); 2) o tempo do discurso (o agora); 3) o lugar (aqui, aí); 4) identidades substitutas na situação.

Para Levinson (2007:74), autor do qual tomaremos emprestado ideias para elaborar a proposta aqui desenvolvida, a dêixis diz respeito 
às maneiras pelas quais a linguagem gramaticaliza traços do contexto no ato de fala. Decorre daí que a interpretação precisa levar em conta o contexto dêitico da enunciação, pois só as sentenças consideradas em contextos específicos expressam proposições definidas: "é apenas o contexto de uso que nos diz de que maneira compreender (as sentenças)". Em geral, a dêixis é organizada de maneira cêntrica a partir do falante, ancorada em pontos específicos do acontecimento comunicativo, criando os centros dêiticos: a pessoa central é quase sempre o falante, o tempo central é o tempo em que o falante produz a enunciação, o lugar central é a localização do falante, assim como o centro social é a posição social e hierárquica do falante, à qual a posição dos destinatários é relativa. Irradiando-se do falante, completa Levinson, há vários círculos concêntricos que distinguem diferentes zonas de proximidades espacial e temporal. A partir dele, linearmente ordenada, parte a linha que estabelece os acontecimentos do passado e do futuro, etc. Apesar do autor realçar a pessoa do falante como referência de partida, a meu ver os círculos dêiticos devem ser considerados em termos do relacionamento dele com o seu interlocutor, conforme aqui farei.

A ideia de círculos dêiticos concêntricos parece-me capaz de representar de maneira sistemática as influências do contexto sobre os atos de fala. Essas influências estão sintetizadas na Figura 1. Partindo da localização espaço-temporal do falante e seu interlocutor, de onde irradiam os dêiticos, e das informações pragmáticas, os círculos concêntricos se expandiriam desde as condicionantes situacionais mais empíricas (o aqui e agora do ato) até as mais sutis, de caráter mais subjetivo (culturais, políticas, ideológicas), situadas nos ciclos mais externos. 


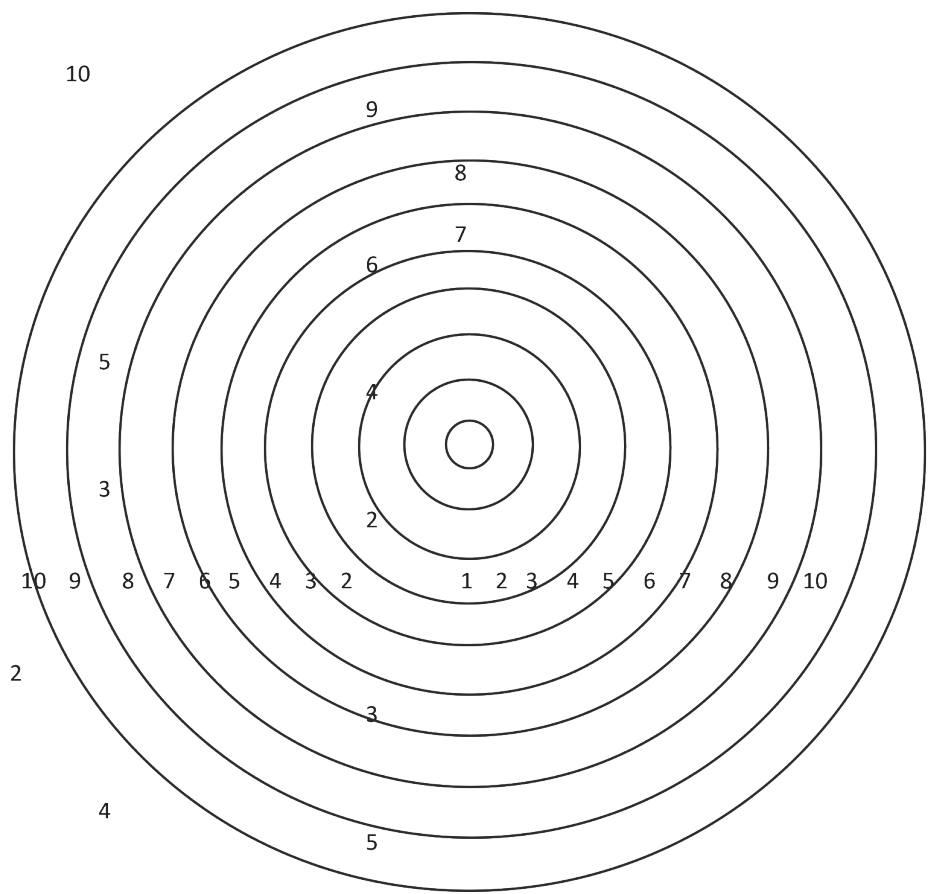

6

7

8

9

Figura 1. Dêiticos Concêntricos dos Atos de Fala

1) Identidade dos sujeitos participantes, o lugar social que ocupam, seus interesses e intenções comunicativas; 2) Coações institucionais, normas profissionais, etc.; 3) graus de hierarquias entre os sujeitos da enunciação e suas condicionantes na interlocução; 5) Espaço físico e sua influência na enunciação; 6) Percepções recíprocas por parte dos participantes dos fatores anteriores; 7) Circunstâncias históricas de ocorrência do ato; 8) Circunstâncias culturais, crenças, mitologias, ideologias, conhecimento de mundo compartido; 9) Memória coletiva de curto e longo prazos; 10) Percepções recíprocas de todo este conjunto de fatores. 
Não será possível aqui explorar com minúcias as sugestões e problemas que surgem da proposta apresentada na Figura 1. Ressalto, porém, que a figura não pretende enquadrar relações de natureza intersubjetiva. A tentativa de colocá-las em uma figura gráfica é apenas ilustrativa. Penso, no entanto, que a imagem de círculos dêiticos pode fornecer pistas sugestivas para as hipóteses interpretativas, tornando a interpretação menos míope. Os fatores indicados nos círculos da figura não possuem fronteiras precisas nem devem ser tomados como 'variáveis antecedentes' objetivas, como já se disse. Eles se superpõem, se influenciam mutuamente e funcionam como uma cadeia de indicadores psicossociais intersubjetivos. Não obstante, ao visualizar os níveis dêiticos, o analista poderá estabelecer hipóteses consistentes, a partir das quais produzir uma interpretação mais sistemática e orientada. Os níveis dêiticos são apenas indicadores a partir dos quais as pistas e traços argumentativos da linguagem narrativa poderão ser interpretados de maneira mais segura. Mas atenção, os fatores que estão no centro ou periferia do modelo apresentado não possuem per se maior ou menor força indutora que os demais. A força determinante de cada nível do contexto dependerá da situação concreta do ato comunicativo, assim como da pergunta de pesquisa de cada projeto.

Parafraseando mais uma vez P. Ricoeur, o que deve ser interpretado em um texto narrativo é a sua proposição de mundo. Não há - observa ele - uma intenção oculta a ser procurada detrás do texto, mas um mundo a ser manifestado diante dele. Por isso, a interpretação precisa ser altiva e ideologicamente crítica, pois o gesto interpretativo é uma 'oposição' às distorções da comunicação humana. Por outro lado, o discurso é um evento que remete aos seu interlocutores, vincula-se às pessoas que falam e ouvem, e a algo ao qual ele se refere (um mundo que pretende descrever, exprimir ou representar). Neste sentido, completa Ricoeur (1983:46), "o evento é a vinda à linguagem de um mundo mediante o discurso". O que 
importa, pois, é a seletividade dos contextos na determinação do valor das palavras e frases a respeito de um determinado evento, pronunciadas por um locutor preciso frente a um ouvinte em uma situação particular.

Retomo, para concluir, às perguntas que originaram as reflexões deste ensaio: como incorporar as determinantes ambientais e históricas na análise da narrativa tornando-a uma análise crítica por natureza? Respondo de maneira objetiva: observando previamente quais motivações e propósitos movem os sujeitos interlocutores a se envolverem em um ato de interlocução. Perguntando previamente: que ímpeto move um narrador a configurar certa proposição de mundo na forma de uma história, em determinada circunstância? Por outro lado, porque determinado indivíduo ou segmento social se presta ao papel de audiência? Que interesses têm cada um dos participantes do ato comunicativo ao se engajar no esforço de coconstruir uma representação narrativa do mundo? Qual é o protagonismo discursivo de cada um deles neste ato? Que circunstâncias cercam esse protagonismo? Há antagonismos? Qual é a correlação de poder entre os protagonistas?

Como observei no início deste ensaio, a textura geral da experiência é hoje transmidiática: entramos e saímos seguidamente no espaço das mídias, de onde retiramos extratos de significação com os quais configuramos as nossas representações de mundo. Nesse complexo contexto, a performance dos agentes interlocutores tornou-se mais proeminente ainda, e a incorporação desse protagonismo à análise, ainda mais relevante. Neste rumo, trouxemos aqui a sugestão de uma teoria ampliada de círculos dêiticos que, a meu ver, fornece subsídios relevantes para a análise das narrativas como atos de fala dinâmicos e circunstancializados. Se a análise imanentista já se revelara obsoleta pelo desprezo ao protagonismo dos agentes, ela revela-se hoje ainda mais inapropriada frente ao dinamismo das narrativas em permanente processo de configuração e refiguração no interior da cultura da convergência. 
Seguindo este raciocínio, propus neste ensaio encarar a narração como um ato de fala comunicativo, e utilizar o modelo dos círculos dêiticos concêntricos para tornar mais sistemático o processo de identificação dos traços e vestígios do contexto no texto, modelo capaz de revelar o jogo de forças de uma ação interlocutiva concreta. Nada garante uma interpretação segura, mas creio que a sugestão de se trabalhar com os ciclos concêntricos dêiticos oferece a alternativa de o analista partir de um lugar mais confortável e confiável para fazer as suas induções. As estratégias argumentativas, os subentendidos e os efeitos de sentido tornarão mais evidentes a proposição de mundo que o texto traz, e proporcionarão uma análise mais forte: a interpretação narrativa torna-se ipso facto uma crítica da sociedade.

\section{REFERÊNCIAS BIBLIOGRÁFICAS}

AUSTIN, J. H. (1962). How to do Things with Words: The William James Lectures delivered at Harvard University, Oxford: Clarendon Press.

BAKHTIN, M. (2003). Estética da criação verbal. S. Paulo: Martins Fontes.

BERLIN, I. (1997). The proper study of mankind. London: John Murray.

CORSERIU, E. (1967). "Determinación y entorno". in Teoria del lenguaje y linguística general. Gredos: Madrid.

DASCAL, M. (2006). Interpretação e compreensão. S. Leopoldo: Ed. Unisinos.

DIJK, T. A. van (2000). Cognição, discurso e interação. S. Paulo: Contexto.

DIJK, T. A. van (1987). In La pragmática de la comunicación literária, J. A. Mayoral, Arco, Madrid.

DUBOIS, J. et al. (2004). Dicionário de linguística. S. Paulo: Cultrix.

EAGLETON, T. (2002). Marxism and literary criticism. London: Routledge.

EAGLETON, T. (2006). Criticism \& Ideology. London: Verso.

FIORIN, J. L. (2005). As astúcias da enunciação. S. Paulo: Ática.

FRYE, N. (1971). The critical path. Indiana University Press, Bloomington: Midland Books. 
GRICE, H. P. (1957). "Meaning". in The Philosophical Review. Vol. 66, No. 3. (Jul., 1957), pp. 377-388.

GRICE, H P. (1969). "Utterer's meaning and intentions". in Philosophical Review. Vol. 78, pp. $147-177$.

LEVINSON, S. C. (2007). Pragmática. S. Paulo: Martins Fontes.

JENKINS, H. (2012). Cultura da convergência. S. Paulo: Aleph.

KOCK, I. V. (2011). Argumentação e linguagem. S. Paulo: Cortez.

MARCHESE, A. e J. Forradellas (1998). Diccionário de retórica, crítica y terminologia literária. Barcelona: Ariel.

MOTTA, L. G. (2013). Análise crítica da narrativa. Brasília: Ed. UnB.

MOTTA, L. G. (2006). Notícias do fantástico. S. Leopoldo: Ed. Unisinos.

REYES, G. (1994). La pragmática lingüística. Barcelona: Montesinos.

RICOEUR, P. (2010). Tempo e narrativa 3. S. Paulo: Martins Fontes.

RICOEUR, P. (1995). Tempo e narrativa 2. Campinas: Papirus.

RICOEUR, P. (1994). Tempo e narrativa 1. Campinas: Papirus.

RICOEUR, P. (1983). Interpretação e ideologias, Francisco Alves, Rio de Janeiro.

SCOLARI, C. A. (2009). "Transmedia storytelling: implicit consumers, narrative worlds and branding contemporary media productions". in International Journal of Communication 3, pp. 586-606.

SEARLE, J. R. (2001). Mente, lenguaje y sociedad. Alianza, Madrid.

SEARLE, J. R. (2002). Intencionalidade. S. Paulo: Martins Fontes.

SEARLE, J. R. (2002a). Expressão e significado. S. Paulo: Martins Fontes.

SILVERSTONE, R. (1999). Why study the media? London: Sage.

SPERBER, D. e WILSON, D. (1986). La relevância. Madrid: Visor.

VIDAL, M. V. E. (2002). Introducción a la pragmática. Barcelona: Ariel.

Villanueva, L. M. V. (2000). La búsqueda del significado. Madrid: Tecnos. 
(Página deixada propositadamente em branco.) 


\title{
CONSIDERAÇÕES SOBRE A MÁQUINA NARRATIVA
}

\author{
Maria Augusta Babo \\ FCSH - Universidade Nova de Lisboa
}

\section{Uma introdução}

Porque falamos de narrativa? Porque contamos histórias? Porque designamos a maior parte dos processos de significação como narrativos?

A narrativa é de tal maneira abrangente dos regimes semióticos, dos fazeres discursivos, das práticas significantes que ela se tornou um termo de extensão máxima e de compreensão mínima, pelo menos na sua utilização pelo discurso do senso comum. Para além de se verificar uma distinção entre narrativa entendida no seu sentido mais restrito e outras formas de discursivização como o diálogo, a argumentação, a descrição, entre outras, dir-se-ia, num primeiro momento, que a narrativa é uma máquina de textualização do mundo e da experiência. É desta afirmação que partimos e à qual iremos chegar tentando demonstrar esse estatuto da narrativa e o seu funcionamento. Mais precisamente, a narrativa tem uma relação estreita com o tempo. Ela organiza, configura a temporalidade do e no humano. A narrativa é, vista por este prisma, a máquina semiótica por excelência, não dependendo do regime semiótico em que elabora, que pode ser imagético, ou outro. Ela opera a um nível macro e não frásico, por um lado, e é uma estruturação subjacente à manifestação 
discursiva, por outro. Assim, a narrativa romanesca não difere da narrativa fílmica ou da narrativa em $\mathrm{BD}$ já que os mecanismos semióticos que a compõem são os mesmos. Tratar-se-á, em qualquer dos casos, de organizar a temporalidade inerente à organização das ações entre elas.

Considerada por alguns especialistas como uma estrutura inata, a elaboração narrativa está patente no próprio desenvolvimento do sujeito falante que, quase simultaneamente à aquisição da linguagem, tende a narrativizar a experiência da forma mais elementar e simples; um primeiro grau de narrativização que articula o relato através da preposição - depois, e depois, e depois... - numa sucessão infinita. Se ainda não se está perante uma organização complexa da temporalidade que a narrativa, nas suas formas mais elaboradas, fornece, deparamo-nos com um primeiríssimo movimento, espontâneo, de ordenação temporal, produtor de efeitos de sentido que extravasam a própria sucessividade, como se verá adiante. Narrar é humano e será talvez a narração (o relato ou o discurso rapporté), e não tanto a faculdade de linguagem, aquilo que distingue o simbólico, no ser humano, relativamente a outros códigos existentes em várias espécies animais. É que, relativamente ao discurso no presente e em presença, caso do diálogo, quer no relato simples - o discours rapporté - quer na narrativa, uma organização mais complexa e elaborada, existe um diferimento do dito e, sobretudo, uma suspensão do regime constativo, performativo, ou, como o designou Deleuze, do regime de palavra de ordem, existentes no primeiro caso. Quer isto dizer que passamos dos regimes discursivos da transmissão de informação, da criação de efeitos imediatos, da ação à sua representação; não à representação direta do mundo, não é disso que se trata em nenhuma narrativa, mas a um diferimento da ação. Narrar é já contar um discurso, uma voz, uma ordem, um ato de fala. Narrar um ato de fala é retirar-lhe a sua atualidade, a sua performatividade, a sua capacidade de intervir diretamente na situação de comunicação. 
Narrar é diferir, distanciar, tornar indireto o que no discurso é direto. Essa passagem, essa operação gramatical, em que consiste a própria gramatização da experiência, é aquela mesma que executa todo o sujeito falante, como o entendeu Benveniste, quando passa do regime atual do discurso direto - evento, fala, ordem, ação em palavras - para a sua narração, indireta, despessoalizada, desfazada da situação de discurso e, portanto, não atuante nela: diferida. A narração por oposição ao discurso, para o linguista francês, dá-se exatamente por uma modificação do campo da deixis, pela passagem do sujeito da enunciação - eu - ao sujeito do enunciado - ele/ela que acarreta o deslocamento do tempo - agora - e do espaço - aqui. Deslocamento do sujeito que passa do seu estatuto de pessoa-subjetiva a um estatuto de não-pessoa (Benveniste, 1966: 231). Narrar é distanciar-se do tempo e do espaço, do aqui e do agora, deslocando, nesse distanciamento, o sujeito para fora de si; alter-ando, objetualizando o sujeito. Narrar é inscrever o sujeito como objeto (da ação). Daí que uma diferença intransponível se estabeleça entre discurso e narrativa. A sua incoincidência advém deste deslocamento espacio-temporal, de um diferimento que colocará a narrativa, sempre, fora do tempo da história e o narrador com ela, num mundo onde já não pode intervir. A narrativa nega o presente, mesmo quando ela aí se coloca como estratégia discursiva. Será sempre, de cada vez, um presente embraiado, quer isto dizer, uma enunciação enunciada, como the chama Greimas.

Ora, este distanciamento que a narrativa como máquina cria relativamente ao real, ao vivido, à experiência, não é outra coisa senão a própria condição de todo o texto ao operar uma semiotização do mundo. Na verdade, textualizar o mundo, textualizar a experiência, a ordem do vivido, é criar um investimento significante por sobre os fenómenos; é aplicar-lhes uma máquina de semiotização, quer dizer, é constituir um todo de sentido através da articulação de enunciados que se tornam, enquanto totalidade, autónomos e, nessa medida, 
diferidos. A textualização liberta-se da sua ancoragem ao contexto. Resiste ao contexto, desliga-se, por essa capacidade de mîse-en-distance, para funcionar como um todo de sentido. Um olhar sobre o mundo que cria mundo. A narrativa não será senão a máquina mais perfeita, mais acabada de textualização do real.

Máquina do tempo, a narrativa assenta num complexo mecanismo de organização da temporalidade. Tempo e narrativa estão, pois, indissoluvelmente ligados, sendo a própria máquina narrativa o dispositivo por excelência de conferição de uma organização ao tempo vivido, ao tempo cósmico, ao tempo convencional, até.

A remissão da temporalidade para a ordem da linguagem é levada a cabo por Agostinho, naquilo que ficou conhecido pela conceção de um tempo interior. Na verdade, essa interiorização do tempo só é possível dado que a própria linguagem o organiza para o sujeito do discurso. Assim, Agostinho ao colocar-se a questão ontológica sobre a temporalidade (o que é o tempo? Questão aparentemente ingénua na sua formulação - 2001: 299) dá-se conta que revém à linguagem a função de o organizar para o sujeito, ou, dito de outro modo, que o sujeito advém na linguagem porque é esta que o coloca: o sujeito é na linguagem. E o presente é, por excelência, o tempo que opera essa coincidência, essa fusão entre a linguagem e o sujeito. Embora, e nisso reside a própria aporia da temporalidade, o presente seja, de cada vez, evanescente.

Agostinho formula assim as três dimensões do presente na sua projeção interior: «o espírito espera [expectat] e está atento [adtendit] (este verbo lembra a intentio praesens) e ele lembra-se [meminit]" (2001: 314). O tempo é assim uma afeção, tensiva ou distendida, conforme se mede a sua extensão ou a sua intenção e estas, no interior da própria linguagem. Há, pois, três operações do espírito e são elas que medem o tempo: a expetativa, a (a)tenção e a memória. A narração implica distensão e projeta-se na e pela memória: são as confissões que se distendem por todo o seu passado que constituem 
o próprio exercício de narrativização do vivido, assim legado à humanidade inaugurando uma configuração narrativa que criará mesmo um género literário.

Ao entender a autobiografia como máquina narrativa pretende-se salientar a existência de um dispositivo narrativo que condensa mecanismos vários para constituir um todo homogéneo centrado no próprio. Essa máquina narrativa usa processos ficcionais, isto é, todo um conjunto de procedimentos figurativos da ordem do imaginário, mas inseridos no quadro de uma articulação narrativa. Na verdade, a autobiografia, considerada nesta perspetiva, participa do testemunho de vida mas também da ficção, no sentido de elaboração imaginária, da verdade do sujeito emergindo em configurações variadas, imagens manipuladas, deturpadas até, possivelmente. É, porém, a narrativa que subsume toda essa heterogeneidade e lhe dá uma configuração temporal e lhe confere sentido.

\section{A organização narrativa}

O termo "narrativa" está de tal forma vulgarizado que ele ocorre como sinónimo de discurso, como foi referido. No entanto, a narrativa é uma máquina bem precisa que integra mecanismos próprios e desempenha funções determinadas na conferição de sentido. Desde já se afirma que a máquina narrativa é a mais poderosa máquina de conferição de sentido ao tempo e, consequentemente, ao acontecimento. Entender como ela funciona será importante para determinar a sua especificidade e para a desinserir do discurso em geral, de qualquer ato discursivo, como geralmente é empregada.

A narrativa é, como foi afirmado, um distanciamento no tempo. Pôr à distância, organizar na distância do tempo, na ausência do sujeito; fazer o mundo vir à ordem da linguagem, semiotizar ou gramatizar o mundo, como se poderá formular nas diferentes perspetivas de 
análise. É, portanto, e antes de mais, um dispositivo de diferimento, não coincidente com "a presente instância do discurso", como designou Benveniste o ato discursivo. Narrativizar será uma operação semiótica que, ao mesmo tempo que distancia o sujeito do real vivido, da res, lhe atribui sentido e, portanto, uma legibilidade própria e comum. É assim que B. Lamizet entende a semiotização do acontecimento, por exemplo (2006).

Então, narrar começa por ser articular ações umas com as outras; dar-lhes uma sequência, dispô-las por ordem de ocorrência. A este primeiro nível corresponde a compulsão intuitiva à narração que todo o sujeito falante, desde a sua aprendizagem e aquisição de competência, elabora, de uma forma muito simples, a que já aludimos: a organização cronológica das ocorrências. A articulação de um antes e um depois é uma primeira operação de narrativização dos acontecimentos, das pequenas situações do quotidiano de que o sujeito faz a experiência de apropriação. Ela constitui a própria estruturação dos acontecimentos nas suas posições relativas, através da ordenação temporal. O tempo que flui ininterruptamente, segmenta-se em ações e é ordenado cronologicamente. Inerente a esta primeira operação está já a capacidade de segmentação, de tornar descontínuo o que foi vivido como contínuo e de lhe conferir uma dimensão significante, ao atribuir sujeitos às ações, ao nomeá-las como motores da narrativa, ao atribuir-lhes consequências ou objetos sobre que recaem. Designa-se por sequencialidade esta ordenação do Khronos. E, ao contrário do que precipitadamente se considera, não constitui a única operação nem sequer a mais importante da máquina narrativa. Pode definir-se esta operação como uma operação de relato que, compondo a complexa máquina de narrar não a esgota por certo. U. Eco deu como exemplo aos seus alunos um pequeno relato da sua chegada à Universidade de Bolonha para dar aulas. Perante a sequencialidade das ações de rotina por ele contadas, os estudantes, atónitos, perguntaram-se qual a razão de ser de tal relato. 
É que, na verdade, nada nele justificava a narrativa. O que falta a um relato para ser narrativa, portanto? Diríamos, com Umberto Eco, que falta um acontecimento marcante. É o acontecimento marcante que fará de um relato uma narrativa, isto é, que permite uma mudança de registo com implicações estruturantes.

A narrativa envolve então a transformação de predicados durante um processo. A narrativa é mesmo esse processo de transformação que conduz de um antes a um depois, tal como por exemplo a gramática sémio-narrativa da Escola de Paris a determina. De uma forma genérica, a narrativa envolve um fazer transformador de um estado inicial de disjunção entre Sujeito e Objeto para um estado final de conjunção. $\mathrm{O}$ fazer transformador opera esse processo, quer no sentido positivo, da conjunção, quer no sentido negativo ou disfórico, da disjunção. Mas, em qualquer dos casos, é a transformação a grande viragem que executa o próprio processo narrativo, invertendo os conteúdos.

Há uma organização lógico-temporal que suporta a textualidade. A esta organização chamou a Escola de Paris sémio-narativa. A estruturação textual é transfrásica e de ordem semiótica, não linguística. Os modelos narratológicos mais alargados vieram explicar em que consiste a coesão e a coerência textuais em termos estruturais. Só esta estruturação interna permite colocar o sentido como um todo que extravasa a soma dos enunciados. A narratividade, de um lado, e a configuração narrativa, do outro, permitem o tratamento da organização textual, conferindo, no entanto, à dimensão temporal uma função e estatuto distintos segundo a perspetiva adotada. Por oposição à configuração narrativa que elabora a temporalidade intrínseca ao mythos, a estrutura narrativa é de natureza lógica e, por conseguinte, acrónica. Quer dizer que a semiótica está interessada em analisar a constituição do sentido, exercendo uma espécie de ocultação do cultural, da tradição, pelo estrutural, pelo lógico, enquanto a hermenêutica através da inteligência narrativa procura 
definir a configuração da experiência e da temporalidade a ela inerente pela narrativa.

Sejam quais forem as abordagens metodológicas que a narrativa convoca, inúmeros modelos narratológicos que a produção estruturalista e pós-estruturalista levou a cabo, há algo que atravessa todas as perspetivas narratológicas e ainda a hermenêutica narrativa: a existência de um conflito, de um desequilíbrio, de uma suspensão, de um confronto, de uma polémica - polemos - quer ela seja, segundo Greimas e Courtés (1986), cognitiva, pragmática ou tímica (relativa aos humores). Para Greimas a narrativa é, por excelência, o lugar da polémica e do conflito: o lugar de uma "concordância discordante", na expressão de Paul Ricoeur que remete para uma dialética da narrativa. Sem essa reviravolta no curso das ocorrências não há verdadeiramente narrativa. É esse inesperado que "modifica o curso da história" num sentido imprevisível, mas que, para se constituir como componente da narrativa, tornar-se "um fator de concordância" (Gilbert, 2001: 60). Acrescente-se, obviamente, e da sua resolução. Enfim, seja o que for que constitua o nó-da-intriga será da ordem do acontecimento. Do acontecimento como rutura; do acontecimento como acontecimento disruptivo, sem o qual não se vê como pode haver narrativa, em que é que a máquina narrativa assenta para o ser.

É de realçar que a narrativa exige uma unidade temática, unidade essa que será mais da ordem da unidade das ações, assumidas por um só sujeito. Há um denominador comum entre drama e narrativa, a unidade de ação. A Poética de Aristóteles coloca bem a especificidade do que aqui se joga, quer no drama, quer na narrativa. A narrativa tem a capacidade forte de tecer-se à volta de uma ação central, de estabelecer um enredo, por exemplo, aquilo que na Poética é referido como o mythos e que Ricoeur traduz por nó-da-intriga. Tomando o termo de empréstimo a Platão (Ricoeur, 1983: 62), o mythos em Aristóteles reúne simultaneamente a composição dramática e a composição diegética. A tragédia é representação de ação, é 
uma construção, encontra-se intrinsecamente ligada à fabricação do mythos, a ação encarada como um todo orgânico. A representação tem como finalidade, na tragédia, a instauração de uma ordem de causalidade na ação, um ordenamento do mythos - o nó da intriga - que permite falar já de uma operação de universalização por sobre o acontecimento singular. A atividade mimética no seu sentido original, mimesis, é, pois, uma operação de criação de um muthos universal. O fazer representativo afasta-se tanto mais da cópia, do representado, quanto a representação implica um redimensionamento da ação e uma re-configuração do particular no geral. É esse o sentido do trágico aristotélico. Quer isto dizer que a representação como atividade poiética confere uma coerência orgânica à sucessão puramente temporal das ações que permite fazer sair estas, enquanto organizadas, da pura contingência do acontecimento real para as inscrever numa ordenação geral, numa verdade que é sobretudo um ordenamento segundo o necessário. A diegese, por seu turno, constitui esse diferimento da narração que, em vez de nos aparecer de frente, no momento da sua representação, nos é contada, em diferido, por um narrador, uma instância que elabora e medeia a ação, que possui um ponto de vista, que se inscreve, no plano mais apagado de todos, como uma instância ausente. É, propriamente, a história (Reis e Lopes, 1991). O nó-da-intriga tudo convoca e tudo emaranha; a narrativa, por seu lado, deslindará este emaranhado de ações que se oferecem como resistência ao sentido, enigma.

Se, portanto, concebermos como estruturante da narrativa o acontecimento disruptivo, se o considerarmos o punctum da narrativa, então deparamo-nos com a verdadeira aporia da narrativa tal como Ricoeur a entende. As narrativas canónicas - e há que distinguir entre a narrativa como texto concreto, preciso, nomeável (o conto, a novela, o romance) e a narrativa como máquina ou gramática de texto - apresentam, todas elas: um princípio ou situação inicial, uma transformação, núcleo, ou nó da intriga e uma situação final ou 
desenlace. Ricoeur define o nó da intriga como essa organização de acontecimentos que transformam o relato em história e constituem a narrativa. Este nó da intriga é a própria articulação lógica dos acontecimentos que, ao mesmo tempo, destroem a situação inicial, que a invertem, a desestabilizam. Ora, o que acontece na estruturação narrativa, o que a máquina narrativa vem conferir à sequencialidade temporal de acontecimentos ligados por uma temática, assumidos pelos actantes, é justamente uma organização poderosa dessas ações de modo a trazê-las, mesmo se invertidas, a um desenlace. O desenlace é o telos da narrativa e ao mesmo tempo aquilo que enclausura o nó da intriga resolvendo-o. Ora, o mythos que constitui a narrativa possui uma organização lógica que dá consistência à própria narrativa, que é, até, a própria finalidade da máquina narrativa. Essa coerência lógica é subsumida pela causalidade narrativa. Quer isto dizer que os acontecimentos que se sucedem na manifestação narrativa estão ligados mais fortemente, do ponto de vista lógico, por uma articulação causal. Aquilo que na Antiguidade era aforisticamente formulado na célebre máxima: post hoc, ergo propter hoc, que se traduz, mantendo a concisão latina, por: depois disto, então por causa disto. A expressão latina dá-nos a dimensão da forte articulação que a máquina narrativa traz ao encadeamento cronológico dos acontecimentos propondo-nos a chave dessa sucessividade. Se B acontece depois de A então, deveremos concluir que A provocou B ou que A é a causa de B. Esta transposição da ordem da sequência cronológica para a ordem da lógica causal está de tal maneira enraizada no senso comum que ela explica logo por si qualquer acontecimento que surja como irrupção na rotina temporal. Dito de outro modo ainda, a conferição de uma causa a um acontecimento (disruptivo) vem trazer-lhe um imediato princípio de explicação e, portanto, de regularização desse mesmo acontecimento, rebatendo-o na sua sequencialidade. Essa conferição de causalidade é a própria ação da máquina narrativa; a máquina narrativa empresta uma lógica 
causal à sequência (arbitrária ou contingente) de acontecimentos de modo a absorver o acontecimento, justamente inexplicável, porque saindo fora da rotina, da sucessão, de novo à sua explicação. O que a máquina narrativa opera ao jogar por sobre os acontecimentos, essa lógica da causalidade, subsumindo-a na sequencialidade temporal, é precisamente, trazer a exceção à regra, trazer o disruptivo ao causal, trazer o contingente ao necessário. A tal universalização que elabora por sobre o acontecimento real para o devolver já como semiotizado. É nessa semiotização e nesse distanciamento do real que ele ganha uma “consistência simbólica” (Lamizet, 2006: 280) e é apropriável então pela comunidade, é universalizável.

$\mathrm{Na}$ verdade, esta função primordial da narrativa ultrapassa a própria lógica causal para vir assumir, na teoria narrativa de Paul Ricoeur, um estatuto determinante no conceito de configuração narrativa, que constitui a dimensão hermenêutica mais profunda da própria máquina narrativa como máquina de conferição de sentido (narrativo) ao acontecimento (disruptivo). A configuração narrativa é uma avaliação global do fenómeno. Olhada pela perspetiva da mise-en-intrigue, a configuração narrativa subsume uma oposição, à primeira vista inconciliável, entre temporalidade, na vertente de duração, e acontecimento. Uma é organizada, linear e contínua, o outro disruptivo, fragmentário, descontínuo. Esta aporia dá lugar, na análise ricoeuriana, à trilogia Temps et Récit (1983, 1984, 1985), que trabalha a articulação entre acontecimento e temporalidade narrativa nas suas diversas configurações, desde a narrativa de ficção, passando pela narrativa da história, até à constituição da refiguração como "um regresso" à experiência, agora do leitor.

É que a configuração narrativa da temporalidade elabora por sobre a heterogeneidade dos tempos e dos acontecimentos. Para Ricoeur, a noção de configuração narrativa permite resolver a descontinuidade inerente ao acontecimento. A força disruptiva do acontecimento vemlhe da sua própria natureza. A mîse-en-intrigue tem, justamente, por 
função inverter esse "efeito de contingência" (Ricoeur, 1990: 169) em "efeito de necessidade ou de probabilidade" que o ato configurador exerce. É o que afirma Ricoeur desenvolvendo a sua tese: "A inversão do efeito de contingência em efeito de necessário produz-se no próprio âmago do acontecimento..." (1990: 170).

Note-se, contudo, que a contingência do acontecimento, que faz dele precisamente acontecimento, e o seu carácter necessário na narrativa não são da mesma ordem. Esta passagem da contingência ao necessário dá-se na elaboração après coup, na diegese, isto é, no próprio ato de contar, de "pôr em intriga", porque narrar será trazer um olhar organizado àquilo mesmo que surgiu como disrupção. A proposta de uma inteligência narrativa ricoeuriana vai no sentido de conceder à narrativa essa finalidade hermenêutica última que é a da conferição de sentido ao acontecimento, isto é, uma organização temporal que, articulando o acontecimento num conjunto de ações, lhe propõe uma causalidade; the devolve um telos, uma finalidade, um sentido. Apesar das surpresas, das peripécias, das contingências da história, uma narrativa orienta-se para uma finalidade, tem uma função teleológica que é assumida pela conclusão e que procede à clausura textual (narrativa), até porque, na sua estruturação, a narrativa pode ler-se invertida, de trás para frente, mostrando a ligação intrínseca de cada sequência narrativa ao todo e à sua finalidade.

A narrativa como dispositivo de mediação é, desde logo, conferidora de sentido através da organização de uma temporalidade que se encontra, a partir de então, ligada, isto é, indissociável. Daí que o acontecimento, disruptivo em si mesmo, se converta em ação necessária à prossecução da intriga. O ato configurante, que é, para todos os efeitos, um ato semiótico, leva a cabo uma compreensão deste todo articulado pois, à medida que a narrativa se forma e vai articulando ações, ela também lhes confere um dado ponto de vista, o do narrador, e até, muitas vezes, uma avaliação. É o que acontece explicitamente na fábula como género narrativo onde essa avaliação 
final nos é dada como "moral da história". Nessa medida então, a narrativa extravasa da sua clausura textual para vir conferir uma compreensão e uma interpretação ao acontecimento agora narrativizado. Na sua expressão mais aberta, a narrativa comporta um juízo de natureza reflexiva. Ora, justamente, a noção de configuração aplicada à narrativa vai Ricoeur buscá-la a L. O. Mink:

\begin{abstract}
ao compreendermos em conjunto os acontecimentos em atos configurativos, a operação narrativa tem o carácter de juízo e mais precisamente de juízo reflexivo no sentido kantiano do termo: contar e seguir uma história é já 'refletir sobre' os acontecimentos com vista a englobá-los em totalidades sucessivas (Ricoeur, 1980: 5).
\end{abstract}

A narrativa será, portanto, antes mesmo ou para além do seu registo ficcional, um ato judicativo. O narrado incorpora um juízo que, ao mesmo tempo, se distancia do mundo e o interpreta, avalia esse mundo que ele próprio fabrica no simbólico. E esta operação advém de uma especificidade muito própria à narrativa, a de facultar a passagem do dizer ao contar. Se o ato discursivo se dá no corpo do sujeito, pela fala, pela presença, a narrativa como escrita opera já uma cesura. Digamos, com Bernard Lamizet: "Enquanto fazemos corpo com a fala, enquanto dizemos através da nossa voz ou ouvimos pelas nossas orelhas (...), escrever o acontecimento ou lê-lo é encontrar-se confrontado com a materialidade de um significante que nos é exterior, o da escrita" (Lamizet, 2006: 121) A narrativa é esse exterior objectualizante que opera a mediação entre a "mutabilidade" da vida e a "continuidade da história".

A procura ricoeuriana de constituição de um si-mesmo, distinto do eu-mesmo, assenta na importância dada aos processos de mediação e à temporalidade. A identidade narrativa é disso o exemplo, por excelência. O si-mesmo constrói-se a partir da mediação narrativa. Esta 
"função mediadora que a identidade da personagem exerce entre os polos da mesmidade e da ipseidade /.../" (1990: 176) pode ser conferida pela própria literatura. Aquilo que está indissoluvelmente ligado à vida é, portanto, a narrativa. E, nessa medida, para Ricoeur, a noção de identidade confunde-se com a de identidade narrativa. Por aqui se entende a função configuradora da narrativa na constituição dessa entidade que é a identidade ipse - a ipseidade. O eu torna-se um sujeito do fazer; identidade do ipse, no percurso narrativo. Uma identidade como que objetivada e investida de sentido. É a narrativa, na sua inscrição textual, que vem configurar, não o eu do discurso, simples deítico, mas o eu capaz de subsumir uma temporalidade organizada: a subjetividade mais ou menos fictícia que atravessa e se organiza numa vida contada. A literatura dá forma e também espessura à subjetividade, pela capacidade que tem de conferir existência e exterioridade à interioridade do sujeito; mas, ainda pela capacidade que possui de o fazer atravessar o tempo. A sua existência na escrita é a condição mesma da sua própria existência ipse. E isto, quer a narrativa seja ou não ficcional. Se há uma ficcionalidade operativa inerente à máquina narrativa, essa ficcionalidade não deixa, no entanto, de se revelar a própria veritas do sujeito. O texto narrativo é essa instância produtora de subjetivação; devolve-nos um mundo interpretado e é dele que a subjetividade emerge, não como origem mas como resultado.

\section{A narrativa da história ou a história como narrativa}

Na medida em que narrar é uma prática de mediação simbólica que começa por fundar o discurso comum, a constituição do campo da narrativa faz-se a partir de uma homologia entre a narrativa ficcional e a narrativa da história. Em ambos os casos dá-se o facto de a operação configurante ser a mîse-en-intrigue, na medida em que a inteligência narrativa, enquanto "síntese temporal do heterogéneo" 
acontece em tanto para a ficção quanto para o domínio do factual (Ricoeur, 1984: 230-233). Para Ricoeur, porém, as dissimetrias, assentam na questão da verdade. Assim, as fronteiras entre configuração - organização do sentido - e refiguração - aproximação à referência, ao ato - não foram nem podem ser derrubadas. O que distingue ambas as narrativas está para além da própria organização interna, situando-se na transcendência do texto. Trata-se, neste entendimento da questão, da confrontação entre o mundo do texto e o mundo de vida do leitor. Ora, na dimensão já mais englobante que lhe confere Ricoeur, pode dizer-se até que também a narrativa ficcional tem uma pretensão à verdade, pois originária ou não do imaginário, ela confere uma certa verdade do sujeito, do tempo, da ação.

Na sua dimensão puramente formal, isto é, na própria máquina de produção da mîse-en-intrigue, a análise semiótica vem mostrar uma engrenagem homóloga às narrativas ficcionais e não-ficcionais. Não é, portanto, no plano da configuração narrativa que encontramos dissimetrias entre narrativas de ficção e de não-ficção. A fronteira entre sentido e referência, ou, nos termos de Ricoeur, entre configuração e refiguração, não será transposta, como o próprio afirma, "desde que o mundo da obra seja uma transcendência imanente ao texto", isto é, na medida em que a referência (de base) deixar de ser a realidade para passar, tanto num como no outro caso, a ser o mundo que o texto cria, ou o "quase-mundo do texto”. De notar, ainda com Ricoeur (1984: 233), que a ficção elabora de forma praticamente ilimitada desdobramentos temporais. Ora, o desafio do sentido e da referência só é atingido no horizonte de uma teoria da leitura que determine essa refiguração, a integração do texto no "mundo de vida do leitor". Como assinala ainda o autor, a singularidade da sua proposta vem do facto de ela "não separa[r] a pretensão à verdade da narrativa de ficção daquela inerente à narrativa histórica, e esforça[r]-se por compreender uma em função da outra” (Ricoeur, 1984: 234). 
Se a distinção entre ficção e história parece inabalável, segundo a taxinomia dos géneros literários clássicos, na verdade ela é muito ténue ou, diríamos, demasiado complexa, pois justamente a ancoragem ao real nunca é direta nem da ordem da simples transparência. E, se é verdade que podemos afirmar que a narrativa da história obedece, no entanto, à máquina configuradora, capaz de temporalizar, de organizar, de religar ações, também não é menos verdade que a narrativa ficcional é um documento insubstituível no estudo, por exemplo, dos costumes, das práticas sociais, dos códigos de classe, ou dos perfis psicológicos e antropológicos de uma qualquer época da história. Nessa medida, o ficcional não é menos verdadeiro que o factual. O romance, quer ele seja realista ou naturalista mas, por que não, o romântico, é exemplo da ficcionalidade narrativa em que o grau de elaboração é tão apurado que serve o discurso da história com uma fidelidade e complexidade espantosas. O ficcional pode, nesta perspetiva, ser lido como documental, testemunho. Por outro lado ainda, desde o momento em que cabe à operação de refiguração, a tarefa de ancoragem do "mundo do texto" no horizonte da leitura, toda a narrativa ficcional ou não, despertará, por certo, uma verdade da leitura, um confronto que toca ou interpela a verdade.

Associar a narrativa da história à ficção será, portanto, uma identificação precipitada e inexata? De facto, a máquina narrativa, sendo constituída por um conjunto de procedimentos em análise, tem necessariamente uma relação, a definir, com o seu referente. Toda a narrativa, sendo produção de sentido sobre a experiência ou o campo do imaginário, releva, necessariamente de uma relação complexa com o real a que faz apelo, donde parte ou que produz. O equívoco da teoria da representação que elege o realismo como o seu modo de ser é pensar a linguagem como transparência (Foucault, 1966: 133), uma espécie de adesão do simbólico, ou até a sua aderência ao real. O que a perspetiva semiótica na sua visão englobante vem mostrar é que essa transparência é ilusória, já que todo o representante gera 
semiose que opacifica necessariamente a sua relação ao objeto. Donde, não há, no simbólico, representação pura, mas constante produção semiósica, cabendo mesmo aos próprios objetos e à matéria bruta, quando sobre eles recai o olhar do observador, tornarem-se regimes semiósicos.

No caso do regime textual, quer o documento, quer a ficção são sempre já da ordem da mediação e dos seus dispositivos e, portanto, factos semióticos, passíveis de interpretação. Em que consiste ela? Outras tantas questões se nos levantam:

Como se articula a narrativa com o mundo? Pode a narrativa referir o mundo? De que forma? Neste ponto, as teorias da narrativa divergem, ainda.

Representação vai buscar a sua génese ao termo grego mimesis; mas é da tradução latina que ela ganha um sentido fixo mais restrito, a imitatio. Entendida na sua perspetiva binária, a representação dirá então simplesmente a relação com o referente, o objeto da realidade que é suposto ser representado. Texto e realidade, texto e mundo foram, desde sempre, remissões indiscutíveis, baseadas num empirismo primário. No que respeita uma teoria da narrativa, coube à Nova Poética ter questionado esta relação que a tradição tornou inquestionável, em nome da semiose que se efetua dentro do texto ou de texto para texto. Admitindo que o texto gera sentido e que este sentido não está absolutamente desligado do mundo de textos que o contextualizam, a perspetiva que a Nova Poética ofereceu ao entendimento alargado da textualidade como um longo e variado texto em processo, é o da intertextualidade, que veio substituir a representação mimética e integrar o texto numa relação de reenvios constantes entre textos.

A tese da autorreferencialidade envolve toda a teoria literária, desde Jakobson a Barthes. Contra a referencialidade da literatura, por exemplo, Barthes contrapunha os "códigos de representação", que lhe permitiam definir a referencialidade como "ilusão referencial" 
ou ainda como "efeito de real". A verosimilhança assentando não na adequação ao real mas ao texto comum, uma adequação ao texto circulante do senso comum. Para a corrente pós-estruturalista, então, a referencialidade narrativa é subsumida pela intertextualidade, dado que nenhum texto se cria do nada, ele insere-se, antes, num movimento de interligação, de redite, e a referência torna-se assim uma questão de ideologia, de evocação ou remissão a uma formação discursiva prévia, comum a um grupo, a uma comunidade cultural, etc. Nesta perspetiva, como bem sintetizou Umberto Eco, o referente é, antes, a biblioteca.

Ricoeur, não admitindo a transparência narrativa baseada numa lógica simplista da representação nem abolindo a referência, subsumida pela intertextualidade abrangente, traça uma teoria geral do discurso narrativo, de ficção e histórico. Ambos contribuem, embora de forma diferente, para a mesma "condição histórica" que caracteriza a humanidade. Ambos desempenham a mesma tarefa hermenêutica de compreensão do mundo e do sujeito nele inserido, histórica e culturalmente.

O estatuto do referente é, portanto, muito particular dado que esta noção em Ricoeur não releva exclusivamente do âmbito do fora-de-texto mas é reintroduzida na narrativa, na medida em que constitui um seu efeito (Saudan, 1991). A referencialidade emerge como incontornável na narrativa da história. Nela aparece uma categoria não tratada que é o real passado e que se impõe questionar. Ora, trabalhando as noções de real e de irreal, como categoria do ficcional, não do lado da sua oposição intransponível que é do domínio dos factos, mas do lado dos seus efeitos, verifica-se que elas se aproximam. É já uma articulação entre ambas, essa transcendência na imanência que caracteriza o conceito ricoeuriano de "mundo do texto". Projetando a noção de representância nos efeitos de real, mais do que na análise da sua proveniência, a teoria ricoeuriana remete-os para o horizonte do leitor, esse "mundo efetivo do leitor" (1985: 149) 
que é o seu garante. A forma de contornar e de aproximar ambas as categorias narrativas é então resolvida e reabsorvida pela referência, sempre movente e sempre historizada, constituída pelo mundo do leitor. Há nesta visão um cruzamento necessário entre narrativa de ficção e narrativa da história. Esta abordagem só ganha plenamente sentido se admitirmos que a perspetiva narratológica de Ricoeur transcende o puro texto para desembocar numa filosofia do sujeito e na determinação da identidade que não é outra senão a identidade narrativa, referida atrás. Identidade essa, referente a um indivíduo ou a um coletivo: povo, sociedade, comunidade.

Focando agora mais de perto o texto da história, há a considerar que este integra o dispositivo narrativo de que a própria ficção se serve e parece ser-lhe exclusivo. Em primeiro lugar assinale-se a unidade estrutural da narrativa histórica: a história, embora explicativa, como o são as ciências naturais, é profundamente narrativa, já que narrar é, do ponto de vista semiótico, um modo de explicação dos factos, na medida em que nos fornece as suas conexões internas. Depois, o próprio conceito de intriga integra o discurso da história, na medida em que há uma trama entre as ações ou elas deixariam de ter qualquer pertinência no contexto da história. É que um acontecimento histórico deve participar na elaboração da intriga. Intriga é justamente o conceito que opera a ponte com a ficção. Uma história sustenta-se pela conclusão e pela expectativa que cria, não dedutível mas pelo menos previsível ou quando muito aceitável. E, tal como a ficção, a história também se compõe de acontecimentos episódicos, não estruturantes ou configuradores de sucessão que vêm enriquecer e dar espessura à narrativa.

A disciplina da história exige do observador um distanciamento e uma perspetiva explicativa/compreensiva que desenham uma espécie de meta-narrativa englobante. David Carr (1991: 205/212) pergunta-se se a narrativa não será, no quadro de uma hermenêutica como a de Ricoeur, ao mesmo tempo um dispositivo epistemológico e uma 
instância ontológica. É que ela exerce essa função de compreensão hermenêutica que capta o sentido através do exercício de contar. Tal como a narração, a compreensão de si tem uma dimensão temporal. E daí, segundo Carr, que não seja possível separar a vida, da narrativa dessa mesma vida, já que esta mantém a ligação entre os tempos passado, presente e futuro contra a ameaça da fragmentação, da incoerência e da dissolução. A conclusão que retira é de que uma comunidade se constitui em sujeito da experiência através de um conjunto de ações comuns, projetadas num passado, num presente e num futuro. Encontramos esta mesma conceção em Ricoeur, a possibilidade de uma identidade narrativa aplicada a um sujeito coletivo. Para David Carr, a proposta de Ricoeur, no quadro das ciências humanas, tal como a de Gadamer, reconhece um fundo ontológico da atividade hermenêutica que procura descrever e entender (1991: 209). A questão tal como ela se coloca, então, deverá ser, ao mesmo tempo, epistemológica e ontológica, na medida em que a narrativa para além de ser um instrumento cognitivo é ainda da ordem da compreensão hermenêutica.

O entendimento que tem Ricoeur da narrativa faz desta, a um tempo, uma atividade do conhecimento e uma realidade histórica. Ao ser, num primeiro momento, configurado pela narrativa, o tempo é, posteriormente, refigurado, na medida em que ele faz parte integrante da receção futura sobre acontecimentos passados e constitui propriamente o nosso conhecimento do passado. Se a narrativa possui uma natureza epistemológica, uma vez que ela é capaz de um enfoque sobre o real e nos dá o conhecimento do passado, a sua natureza ôntica traduz-se nessa capacidade de participar na constituição da história futura. Recebida pelos leitores, essa narrativa contribuirá para a constituição da realidade histórica. A ontologização consiste propriamente nesse "modo de existência narrativo" (Carr, 1991: 206). Forma conceptual de entender o passado, a narrativa funda a própria epistemologia da história, não se confinando, portanto, a 
uma noção simplesmente literária. Assim, na perspetiva da filosofia analítica de A. Danto e de L. O. Mink (convocados por David Carr), ela é um "instrumento cognitivo", i. é, "um modo de compreensão", uma forma conceptual de entender o passado. Do ponto de vista ontológico, a narrativa só se aplica à história "na medida em que ajuda a esclarecer a natureza da sociedade”. Uma comunidade só pode constituir-se em sujeito da experiência, de ações comuns, se tem a consciência de um passado, de um presente e de um futuro comuns" (1984: 212).

Ainda uma outra dimensão da narrativa da história salientada por Ricoeur é o facto de a história como narrativa ser uma escrita. A "escrita da história" é uma extensão escritural que extravasa ou gera a própria máquina narrativa, conferindo-lhe um estilo, um enquadramento cultural, no sentido em que toda a narrativa integra e se integra nos modos canónicos da narrativa e nos seus géneros. Esses modos são tantas estruturas quantas as formas culturais codificadas e institucionalizadas. E permitem determinar efeitos de sentido, trágico, epopeico, satírico, e não propriamente determinar a natureza intrínseca do "material a organizar (Ricoeur, 1983: 238).

Há efetivamente uma questão que emerge da narrativa da história e que foi determinada e formulada pelo pensamento francês à volta desse fazer que é propriamente a escrita da história, quer com Michel de Certeau, quer com Paul Veyne e Foucault. Do ponto de vista da estrutura narrativa, quer a ficção quer a história pertencem à mesma categoria, o que aproxima a história da literatura (Ricoeur, 1983: 228). Ora, estas posições, que a escola francesa toma como válidas, permitem colocar a questão da ligação entre a ficção e a história ou entre a narrativa ficcional e, empregando uma expressão menos feliz, a narrativa factual. Tal como a define Paul Veyne, uma das figuras marcantes da epistemologia contemporânea da história, a história não seria senão uma "narrativa verídica" (Ricoeur, 1983: 239), composta de acontecimentos que são colocados em intriga, configurados. Esta 
ambição de verdade que age na narrativa da história estaria suspensa deliberadamente, segundo Ricoeur, na ficção (1983: 315).

Paul Veyne através da análise à abordagem histórica de Foucault, teoriza precisamente sobre o fazer história (1971). Compara a história ao romance, porque ela organiza, seleciona e simplifica, em suma, ela é uma verdadeira mîse-en-intrigue. A história é reconstituição, não diretamente a partir do acontecimento, não se reporta diretamente ao referente mas indiretamente, a partir das suas marcas. Ora, essa reconstituição indireta cria um efeito ou cria como efeito a ilusão da reconstituição direta. $\mathrm{O}$ acontecimento é de uma natureza fugidia, não é físico nem é uma substância; é antes um processo onde se misturam "substâncias em interação com homens e coisas" (Veyne, 1971: 51). Por outro lado, a história constitui-se com base no documento, não no acontecimento. Nessa medida, também, ela distingue-se da narrativa jornalística ou biográfica. A história lida com documentos que asseguram uma relação referencial: da ordem do escrito, da imagem, do património, ou do registo em geral; compara documentos, relaciona-os, discute a sua fundamentação e integra-os numa trama narrativa que os configura. A história é essa mesma configuração que traz uma perspetiva, um juízo, um ponto de vista. E, por isso, não há a História mas histórias. Cada acontecimento histórico é, portanto, suscetível de ser objeto de múltiplas narrativas que o vão configurar sobre diferentes ângulos. Não há História mas textos narrativos que elaboram o passado coletivo de forma organizada, interpretando os factos pelas ligações que a narrativa estabelece ou não entre eles. O real, enquanto passado, será assim um manancial inesgotável de narrativas em devir. E essa potência do real dá-nos também o teor da sua distância e da sua diferença relativamente a cada uma das narrativas por vir, já que, nenhuma narrativa, teoricamente, poderá fechá-lo definitivamente num sentido, numa interpretação.

Concluindo com a posição de Ricoeur neste domínio e apoiando-nos na análise de François Dosse (2012) diríamos que o autor 
foca a história através da textualidade narrativa que lhe dá corpo. É que a vertente narratológica nascida do linguistic turn deu toda a sua importância à explicação narrativa baseada na causalidade, isto é, no facto de haver na conjunção porque "duas funções distintas, a consecução e a consequência" (2012: 144). Por outro lado, existe uma proximidade de procedimentos entre o registo da historiografia e o da ficção no plano da estrutura narrativa. O que leva Ricoeur a concordar com estas posições é o facto de elas mostrarem como narrar é já explicar; mas não partilha a indistinção total com os narrativistas dado que estes abolem o fora de texto ou integram a história no texto infinito das suas remissões intertextuais, como se viu. É, portanto, o regime da veridicção que constitui o limite para além do qual Ricoeur não aceita a visão textualista. A noção de representância, introduzida atrás, constitui o ponto de resistência da referencialidade do texto da história (Dosse, 2012: 146). E, nessa medida, é sintoma da rejeição do textualismo, não cedendo, contudo, ao simplismo da referência pura. Elaborando a referencialidade no âmbito da configuração e da refiguração Ricoeur adota uma perspetiva conciliadora quer no modo de entender a ficção quer no modo de fazer história.

Que formas toma a narratividade hoje? Ricoeur admite que a contemporaneidade rompeu com essa configuração narrativa herdada de Aristóteles, tanto no caso da historiografia como no caso do romance como género englobante da ficção (1985: 387). E, para ele, este impasse não se coloca unicamente do lado das formas configuradoras mas está patente até numa resistência que se verifica nos atos refiguradores, nos limites da refiguração, como os denomina (1985: 387). Os limites da narrativa e a eclosão desses limites na crise das narrativas formarão, tal como o linguistic turn, uma autêntica viragem no pensamento que veio a ser denominado, em consequência, por pós-moderno. 


\section{A crise das narrativas}

Lyotard define a modernidade como uma atitude de pensamento e "ideologia científica" em que há sempre uma narrativa (heroica ou epopeica) a justificar e legitimar a ideia de progresso. As meta-narrativas que suportam tais enunciados são, por exemplo, a hermenêutica do sentido ou a emancipação do sujeito. Pelo contrário, a pós-modernidade desacredita as meta-narrativas. É a crise da filosofia metafísica. Ela localiza-se sensivelmente no pós-guerra, dado que a explosão tecnológica deslocou a questão da finalidade para a questão dos meios da ação.

Em O Inumano - considerações sobre o tempo, (1989: 72) apoiado numa análise da monadologia leibniziana, Lyotard propõe uma perspetiva temporal das sociedades capitalistas desenvolvidas em que tudo se joga numa previsão suportada pelas tecnologias digitais de globalização: os jogos de estratégia. Esses dispositivos permitem ao futuro antecipar-se no presente: "Garantias, confiança, segurança, são meios para neutralizar o caso como se fosse ocasional, para prever, digamos assim, o de-vir" (1989: 73).

Para Lyotard, já nos finais do século XX, as tecnologias eletrónicas iriam provocar um desafio às sociedades contemporâneas desenhando um outro tipo de narrativas, diverso daquele em que o acontecimento é acontecimento passado; tal desafio é o de controlar um processo ao "subordinar o presente ao que (ainda) chamamos 'futuro', já que nestas condições, o 'futuro' será completamente pré-determinado e o próprio presente deixará de se abrir sobre um 'após' incerto e contingente”. O princípio do capitalismo define-se por esta lógica da antecipação que iria hipotecar o futuro no presente das nossas vidas. A lógica da previsão veio a encaixar-se perfeitamente no dispositivo hipertextual e corporizando o enunciado premonitório de Lyotard: "nada mais pode acontecer no tempo t', a não ser a ocorrência programada no tempo t" ". O filósofo desenvolve o conceito dos jogos 
de estratégia, suportados pelas tecnologias digitais de globalização, concluindo: "Aí o futuro antecipa-se ao presente". Encontramos nesta operação generalizada de hipoteca do devir, uma fratura narrativa com o passado, ocorrido e delimitado no passado.

O sistema da economia capitalista sobrecodifica os possíveis em devir. O mesmo se passa na máquina narrativa do hipertexto: o utilizador-leitor tem a liberdade de executar todas as ligações possíveis, mas sempre no seio daquelas que foram pré-estabelecidas pelo sistema de sobrecodificação. O que quer dizer que o potencial de remissões que constitui a própria navegação do leitor está previamente programado, faz parte da própria máquina hipertextual. A liberdade situa-se tão-somente ao nível da atualização dessas conexões, dentro da virtualidade das possíveis. Lyotard prefigurou deste modo o desafio proposto pelas tecnologias de natureza eletrónica às sociedades contemporâneas: o de configurarem um outro tipo de narrativas, não as que encadeiam o acontecimento como acontecimento passado mas sim o de controlar um processo ao "subordinar o presente ao que (ainda) chamamos 'futuro', já que nestas condições, o 'futuro' será completamente pré-determinado e o próprio presente deixará de se abrir sobre um 'após' incerto e contingente" (1989: 72). Deparamonos, então, com a seguinte aporia: quanto mais condicionada é a abertura futura dos possíveis pela sua hipoteca presente, mais as narrativas (hipertextuais, entre outras) deslinearizam o tempo da sucessão, criando uma ilusão de infinitude dos possíveis narrativos. Então, do ponto de vista das grandes formações narrativas, aquilo que distingue as sociedades pré-modernas das sociedades modernas, é, segundo Lyotard, o facto de ambas produzirem e se alimentarem de macro-narrativas ou narrativas totalizantes mas em que, no primeiro caso, são míticas, e em que, no segundo, se fundamentam antes na razão e no saber científico, como instância legitimadora. A pós-modernidade, assistindo ao fim das macro-narrativas, definir-se-ia, por seu turno, pela dissolução do sentido por elas sustentado, dando 
lugar à disseminação de pequenas narrativas, de micro-narrativas constituintes de uma generalizada disseminação de sentidos e sua polemização.

Tendo em atenção a conceção de Lyotard, recorde-se que as narrativas se caracterizam por serem técnicas ou máquinas de ordenação do tempo, de encadeamento do acontecimento, de modo a, numa lógica de causalidade, ou, mais precisamente, numa lógica em que a contiguidade se funde ou coincide com a causalidade, "engendrar o sentido". O fim da narrativa passa por uma abolição dos critérios aristotélicos de unidade e de completude, como o relembra Paul Ricoeur (1984: 35), e esta crise precede o aparecimento tecnológico dos dispositivos digitais de hipertexto. A crise da composição narrativa advém da própria conceção de um real fragmentado, onde o fim não coincidirá jamais com a finalidade, onde a contingência do acontecimento deixa de poder ser subsumida pela ordem do necessário na narrativa.

Do ponto de vista da experiência literária, não é outro o fenómeno que eclode no romance como experiência-limite e que vem, ele também, marcar o aparecimento do pós-narrativo. Por isso, se escolhe como exemplificação, entre muitos outros textos indicadores desta rutura literária, L'Étranger de Albert Camus, publicado em 1942. Não propriamente para analisarmos a máquina narrativa em desagregação neste romance, mas para observarmos a confirmação dessa desagregação que leva Sartre a dedicar-lhe um texto crítico, compilado em Situations.

A propósito de Camus mas também do romancista americano, $\mathrm{J}$. Dos Passos, Sartre teoriza sobre a temporalidade narrativa. Seguindo a já estabelecida perspetiva, que encontramos em W. Benjamin, segundo a qual o romance inaugura já o fim da narrativa, defende aquele que a narrativa, ao contrário do romance, faz-se no passado. A narrativa tem uma prerrogativa, ela explica porque é causal. Ela dissimula, através da ordem cronológica, uma ordem causal. Todo 
o romance onde a ordem das coisas não se deixa agarrar pela ordem das causas não é narrativo, é caso destes autores, convocados por Sartre. Se há um défice de narrativa, se a máquina de articular causas e efeitos está desmanchada, então o que surge são acontecimentos, e "o acontecimento está a meio caminho entre o facto e a lei" (1947). Os acontecimentos, só por si, não produzem narrativa. Falta-lhes a mîse-en-intrigue que os configura em trama. Uma sucessão de presentes, como é o caso por exemplo em L'Étranger, não é uma narrativa. $\mathrm{O}$ romance não obedece à narrativa porque nele a causalidade está ausente. Não explica, descreve, afirma Sartre. Aliás, o absurdo como dimensão filosófica instala-se devido a essa total ausência de causalidade e de teleologia que constitui a vida. Em $O$ Mito de Sisifo, Camus declarara que o ideal do homem absurdo é essa sucessão de presentes onde a causalidade está totalmente abolida. Daí que o romance não seja nem possa ser narrativo. Porque até o romance exige um devir, uma continuidade temporal. Ora, L'Étranger é um romance onde "só o presente conta, o concreto" (1947: 108). A própria personagem, Meursault, "está lá, existe, e não podemos nem compreendê-la, nem julgá-la completamente; ela vive, enfim, e é a única densidade romanesca que a pode justificar aos nossos olhos" (1947: 110).

Em Hemingway encontra Sartre uma sucessão de presentes; há uma descontinuidade do tempo. Em L'Étranger há uma nova técnica (americana) já que se trata de dar uma "sucessão impensável e desordenada de presentes" (1947: 112). Comparando ambos os autores, conclui ele: "O que o nosso autor vai buscar a Hemingway é a descontinuidade das suas frases entrecortadas que se decalca sobre a descontinuidade do tempo". Em última análise, "cada frase é um presente" (1947: 117). Quer isto dizer que elas não estão organizadas mas "puramente justapostas". E mais: "evita-se quaisquer ligações causais que introduziriam na narrativa como um embrião de explicação e que poriam entre os instantes uma ordem diferente da 
pura sucessão" (1947: 118). Aquilo de que se trata nesta obra, pelo contrário, é de "uma tranquilizadora desordem de acasos". Camus, como muitos dos seus contemporâneos, "gosta[m] das coisas por si próprias e não quer[em] dilui-las no fluxo da duração", entende Sartre. Isto explicaria "por que o romancista prefere a uma narrativa organizada este cintilamento de pequenos brilhos sem amanhã em que cada um é uma volúpia”. Resulta daí a própria noção de absurdo, isto é: "nesse mundo que nos querem dar como absurdo e do qual se extirpou cuidadosamente a causalidade, o mais pequeno incidente tem peso" (1947: 119).

Por tudo isso, Sartre não poderá designá-lo como narrativo: “a narrativa explica e coordena ao mesmo tempo que retrata, substitui a ordem causal pelo encadeamento cronológico." Para Camus é um romance; no entanto, para Sartre, "o romance exige uma duração contínua, um devir, a presença manifesta da irreversibilidade do tempo." Não é o que acontece aqui: "nesta sucessão de presentes inertes que deixa entrever por baixo a economia mecânica de uma peça montada" (1947: 121).

A descontinuidade assumida é o que permite retirar um sentido metafísico à sequencialidade e fechamento narrativos. Sartre cita Malraux a este propósito: "o que há de trágico na morte é que ela transforma a vida em destino". A morte é o fechamento da vida, do tempo encadeado, causal.

Ora a conceção de destino, ela própria releva já da máquina narrativa. O destino é uma figura produzida por esta máquina de ordenar e dar sentido ao tempo. Se o trágico elabora a intriga nesta dimensão de destino, antecipando através do coro na tragédia grega a fatalidade do desenlace, o não poder não ser que é a pura negação da contingencialidade da vida, o destino, na narrativa, pode ser tomado como esse olhar, après coup, e cujo desenlace é explicado pela intriga. A figura do destino encontra causas e nexos no que está para trás, devolvendo-lhe essa transcendência metafísica que 
apazigua a disforia insuportável de uma vida, de um acontecimento, de um fenómeno natural. O destino é a figura narrativa que apela a um deus ex machina que tudo regula, independentemente da vontade e da ação humana. O destino é assim a figura por excelência da narrativa em que um destinador subjuga o sujeito, sujeitando-o a cumprir um desenlace mesmo se contra a sua vontade. A própria emergência deste sujeito subjugado ao soberano destino nos mostra como a máquina narrativa propaga a sua ideologia, possui as suas axiologias e organiza assim o sentido das vidas, em história.

A crise das narrativas é, portanto, mais do que uma transgressão de um código ou uma questão de caducidade dos géneros literários, uma forte perceção da sujeição do sujeito à máquina de ordenação causal.

Quando Mallarmé escreve: “Aucun coup de dés jamais n'abolira le hasard", para além da forma poética que inaugura ela própria toda uma poética, trata-se de uma palavra de ordem, de uma rutura, de um grito de libertação, da assunção, enfim, da contingência pura. Não daquela ideologia que vê ainda e sempre no acaso mais uma verificação da impossibilidade da pura coincidência, misturando e aplainando a contingência evencial da vida mas, antes, a declaração tremenda de que a contingência é a lei, de que o tempo são fragmentos dissociados, sem nexo, para os quais não há um qualquer sentido que os sustenha. A poética de Mallarmé é então uma filosofia do tempo, a condição abandonada de um sujeito ao puro acaso sem narrativa, sem origem nem telos. Na amargura da sua crueza contingencial. O puro acaso, sem coincidências. O silêncio da sua finitude.

Da epopeia ao romance contemporâneo, onde o carácter fragmentário e aleatório abandona as suas personagens numa desolação sem deus, eis, em toda a sua extensão, a assunção e queda do dispositivo narrativo e da sua função de produtor de sentido. O devir-biográfico, como movimento de configuração do sujeito, não desligado justamente das máquinas de representação, sejam elas narrativas 
textuais ou icónicas, é o movimento do sujeito moderno, garante da identidade do próprio.

Eis como a condição humana releva desse dispositivo que, no fundo, configura o humano tal como o conhecemos e a ele nos identificamos. Trata-se, em suma, de uma máquina de antropomorfização constante que põe em jogo a difícil conciliação entre o bios e o logos. Constatamos, assim, todo o processo histórico de constituição e construção da máquina antropomórfica que não é, senão, a máquina narrativa.

\section{REFERÊNCIAS BIBLIOGRÁFICAS}

Actes du Colloque de Cerisy-la-Salle (1991), Paul Ricoeur - les métamorphoses de la raison herméneutique. Paris: ed. Du Cerf.

ADAM, J. M. (2001) Les textes - types et prototypes. Paris: Nathan/HER.

AGOSTINHO (Sto) (2001) Confissões, trad. Arnaldo Espírito Santo et alii. Lisboa: INCM. ARISTÓteles (2011) La Poétique. Paris: Editions du Seuil.

BABO, M. A. (1993) A escrita do livro. Lisboa: Vega, coleção Passagens.

BenVeniste, E. (1966; 1974) Problèmes de Linguistique Générale, 1, 2. Paris: Gallimard.

CARR, D. (1991) "Epistémologie et Ontologie du Récit" in Paul Ricoeur - les métamorphoses de la raison herméneutique, Actes du Colloque de Cerisy-la-Salle. Paris: ed. Du Cerf.

DOSSE, F. (2012) Paul Ricoeur - un philosophe dans son siècle. Paris: Armand Colin. FOUCAULT, M., (1966) Les mots et les choses. Paris: Gallimard.

GILBERT, M. (2001) L'identité narrative - une reprise à partir de la pensée de Paul Ricoeur. Genève: Labor et Fides.

GREIMAS, A. J., e COURTÉS, J. (1979, 1986) Sémiotique - dictionnaire raisonné de la théorie du langage, tomos I e II. Paris: Hachette Université.

LAMIZET, B. (2006) Sémiotique de l'evénement. Chippenham: Hermes/Science; Lavoisier. 
LYOTARD, J.-F.(1989) O Inumano - considerações sobre o tempo. Lisboa: ed Estampa. MINK, L. O. (1970) "History and Fiction as Modes of Comprehension". in New Literary History, 1971, pp. 541-558.

REIS, C. e LOPES, A. C. M. (1991) Dicionário de narratologia, $3^{\circ}$ edição. Coimbra: Livraria Almedina.

RICOEUR, P. (1980) La fonction narrative. Paris: ISEO-ICP.

RICOEUR, P. Temps et Récit (1983, 1984, 1985), tomos I, II, III. Paris: Seuil.

RICOEUR, P. (1986) Du texte à l'action - essais d'herméneutique II. Paris: Seuil.

SARTRE, J.-P. (1947) Situations I. Paris: Gallimard.

SAUDAN, A. (1991) "Herméneutique et Sémiotique: intelligence narrative et rationalité narratologique". in Paul Ricoeur - les métamorphoses de la raison herméneutique, Actes du Colloque de Cerisy-la-Salle. Paris: ed. Du Cerf.

TIFFENEAU, D. (1980) La Narrativité. Paris: CNRS.

VEYNE, P., (1971) Comment on écrit l'histoire. Paris: Seuil. 
(Página deixada propositadamente em branco.) 
(Página deixada propositadamente em branco.) 


\title{
IMPRENSA E CONFLITO:
}

\section{NARRATIVAS DE UMA GEOGRAFIA VIOLENTADA}

\author{
Fernando Resende
}

Permanece uma questão cuja resposta procuro: que forma de narrativa nos aproximará do homem? Michel Serres

\section{A Palestina como desafio}

"Julho de 2015. Ataque terrorista em Duma, uma vila situada na região nordeste de West Bank, na Palestina. Um bebê é assassinado, queimado vivo, suspeita-se, por líderes da extrema direita em Israel. Julho de 2014. Uma guerra na já sitiada Gaza, em 50 dias, "matou 2.251 palestinos (1.462 civis) e 72 israelenses (seis civis)" ${ }^{33}$. Pelo menos desde o início do século passado, a Palestina é um território que vive um intermitente processo de apagamento e desaparecimento ${ }^{34}$.

\footnotetext{
${ }^{33}$ Cuenca, J.P. "Um ano após guerra, Faixa de Gaza se torna prisão dentro de prisão". (Folha de São Paulo, 25/07/2015) Em http://app.folha.uol.com.br/\#noticia/576889 (acesso julho/2015)

${ }^{34}$ O Estado de Israel foi proclamado em maio de 1948, fato que para os palestinos passou a receber o nome de Nakba, que em árabe significa a grande catástrofe, pois é o ano que marca o princípio da tragédia que se abateu sobre o povo palestino.
} 
Invadida e ocupada por judeus sionistas, que primeiro contaram com o apoio do Império Britânico, ela é hoje uma nação destroçada por uma política de invasão territorial e por forças bélicas incomensuráveis por parte do Estado de Israel. A pergunta sobre o que é a Palestina, enquanto nação, é uma constante tanto entre os que foram (e ainda são) obrigados a abandoná-la como entre os que lá vivem, impedidos de se locomoverem no próprio território. Edward Said nos apresenta a dúvida que toma uma nação inteira: "Quando nos tornamos 'um povo'? Quando deixamos de ser? Ou será que estamos ainda no processo de nos tornarmos? O que essas grandes questões têm a ver com nossas íntimas relações, entre nós e com os outros? „35

O conflito vivido pelo (e no) território palestino, que acontece pelo menos desde o início do século $\mathrm{XX}$, vem sedimentando marcas por vezes difíceis de serem escavadas. Muitas vezes, por tecer a intriga com vistas a um sem-fim de dados, números e pesquisas, as narrativas da imprensa comportam conteúdos simplificadores que nada mais fazem além de informar - quando assim o fazem - acerca daquele acontecimento. E por este motivo, dentre os vários desafios com os quais a imprensa internacional diariamente se confronta, talvez hoje possamos pensar que narrar aquele território em conflito seja o exemplo maior.

As narrativas da imprensa, de modo geral, quase sempre fragmentadas, desprendidas umas das outras, narram os fatos como se eles fossem desprovidos de contextos, deixando que nelas prevaleçam as dicotomias e os binarismos. Devedor de uma referência ao real, o discurso da imprensa prima pela pressuposição de poder oferecer uma representação do mundo que seja verdadeira, objetiva e imparcial. Um pressuposto respaldado por uma perspetiva histórica e teórica de cunho tecnicista que, entre outros aspetos,

\footnotetext{
35 No original: "When did we become 'a people'? When did we stop being one? Or are we in the process of becoming one? What do these big questions have to do with our intimate relationships with each other and with others?" (Said, 1986:34).
} 
foi também legitimado pela hegemonia de um pensamento dito "científico" e a consolidação de uma racionalidade dita "instrumental ${ }^{36}$.

Assim, uma das perguntas que acompanha esta reflexão - como pensar a imprensa tendo o território palestino como desafio? - parece crucial para nos fazer entender a demanda pela sustentação de outras abordagens teóricas e práticas que coloquem em questão o próprio jornalismo. Como uma das possíveis instâncias de enunciação midiática, no mundo atual, cabe pensar a imprensa para além da sua função primeira, que é transmitir informação? A partir desta indagação, esta reflexão assume a representação e a linguagem como aspectos centrais para a problematização de um jornalismo pautado por um paradigma relacional (Marcos, 2007). Um caminho que parece imprescindível, caso levemos adiante o pressuposto de entender o jornalismo a partir da narrativa.

Como procedimento conceitual, mais até do que um recurso analítico, a narrativa é assim um dos aspectos centrais desta discussão. Tomá-la como um problema demanda assumir posturas epistemológicas que, inevitavelmente, colocam em questão os modos de compreender o jornalismo (Resende, 2011). Como uma instância de enunciação na qual se deflagram lutas e relações de poder, o jornalismo é aqui entendido como uma prática cultural-discursiva, sujeita a alterações no tempo/espaço em que acontece. O que nele há de fixo são suas regras discursivas, estratégias e técnicas que visam à referencialidade do fato que narra. Sob a perspetiva da narrativa, porém, o que se instala é um paradoxo: a organização do caos cotidiano - tarefa que é premente ao exercício do jornalismo - não é garantia de uma representação fidedigna.

\footnotetext{
${ }^{36}$ Em Resende (2008), resenha do livro organizado por Benetti \& Lago (2007), procuro fazer uma reflexão sobre as condições em que se assentam algumas das epistemologias e metodologias fundantes no campo do jornalismo, processo que nos ajuda a entender os esforços do campo em se haver com as contradições entre as perspectivas dominantes e outras relacionadas às problemáticas da linguagem.
} 
Quando se entende a narrativa como lugar de ordem e desordem (Ricoeur, 2010), o que se nota, nas páginas do jornal, são desarranjos e faltas. Certeau nos leva a melhor compreender essa perspetiva ao dizer do relato como espaço criador de delimitações e mobilidades. Diz o autor: "o relato não se cansa de colocar fronteiras" e, ao mesmo tempo, deixar transparecer proximidades traçadas "pelos pontos de encontro entre as apropriações progressivas (...) e os deslocamentos sucessivos (...) dos actantes" (2000: 212-213). Assim, pensar a imprensa a partir da narrativa - esta reflexão sugere - é admitir o conflito como lhe sendo absolutamente constitutivo; dado que se deve buscar reconhecer na narrativa, ou seja, no espaço em que o acontecimento é configurado.

Tendo o território em questão como desafio e a narrativa como um problema, este artigo pretende muito menos se deter a uma crítica sobre os reducionismos a que está submetido o discurso da imprensa do que contribuir para uma reflexão acerca da potência da narrativa, diante, particularmente, das complexidades que regem os conflitos de longa duração. Seu objetivo principal é lançar um olhar que indague acerca dos modos de apresentar e representar o conflito Israel/Palestina. Se no espaço da mídia encontramos "imagens, impactos emocionais de acontecimentos, tão intensos quanto breves", que, de acordo com Matos, só nos fazem "[oscilar] entre a indignação e a compaixão" (2006, 23), não há de se negar que nele também notamos o uso de distintos modos narrativos que chamam atenção para outras possíveis leituras sobre o conflito.

Por esta razão, uma outra pergunta - como tem sido / pode ser narrado o conflito Israel/Palestina? - também nos parece relevante. Ela pode nos fazer compreender quão complexo são os modos de inserção dos sujeitos e dos poderes que se configuram neste território que, antes de tudo, é uma geografia violentada. São infindáveis as tramas que tecem um território no qual a articulação de poderes políticos e econômicos - o Estado de Israel e seus aliados 
- se amalgamam a dinâmicas culturais e religiosas, para dizermos o mínimo em relação aos imaginários que convergem, por exemplo, na cidade de Jerusalém. Falamos, portanto, de várias camadas de narrativas, desejos e poderes que se inscrevem e se instalam, há séculos, em uma geografia que se encontra exaurida.

Exhausted geography - conceito de Irit Rogoff (2000) - é fundamental para a reflexão que este artigo propõe. Ao discutir geografia, espaço e formas de engendramento do conhecimento em territórios que vivem conflitos de longa duração, particularmente os que envolvem a região do Oriente Médio, esta autora reconhece o esgotamento dos recursos epistemológicos e analíticos que até então têm amparado as explicações e reflexões sobre os conflitos. Uma geografia exaurida impõe outros modos de apreensão dos sentidos, outras narrativas, a respeito da vida e da luta que nela se trava.

Assim, reconhecer os modos que o território palestino e seus sujeitos se inscrevem no cenário global contemporâneo é, da mesma forma, muito importante; trata-se de um gesto que nos ajuda a colocar em cena (e em questão) as complexidades inscritas naquele espaço. Nessa geografia violentada, onde quem é dono da terra não pode nela viver, encontram-se sujeitos que carregam experiências identitárias pluri-geográficas e que vivem, ao mesmo tempo, uma ideia de nação que só existe em forma de apagamento (Said, 2011). Nesse lugar, cultura e política se amalgam de tal modo que se torna imprescindível um olhar crítico e uma abordagem teórico-analítica que reconheçam modos de existir como sendo também modos de resistir (Tawil-Souri, 2012).

As camadas de estereótipos e os binarismos que hoje dão forma a este território precisam ser constantemente escavados, debatidos e confrontados. Nesse sentido, a narrativa, através da imprensa e de vários outros sistemas de representação, tem um papel crucial, ela pode ajudar a desvelar os desdobramentos e as contradições que o conflito produz, fazendo-nos ver os conflitos dentro do conflito, 
gerando, em nós, talvez, saberes e experiências mais complexos, algo maior do que simples indignação ou compaixão. Além disso, produzir narrativa é um gesto estético de produção de cultura, o que no caso da Palestina é de caráter eminentemente político (Tawil-Souri, 2012). E é neste lugar que o olhar lançado neste artigo assume uma dimensão política e estética, instâncias absolutamente amalgamadas no mundo que hoje conhecemos (Rancière, 2005).

\section{A imprensa hoje: representação e linguagem como problemas}

Bruno Latour, ao problematizar a producão de conhecimento no mundo que chamamos "moderno", faz do jornal uma metáfora instigante. Para este autor, ao se esforçar para dar ordem às nossas experiências no mundo da vida, o jornal materializa - ou serve como exemplo para se pensar - uma certa crise no processo de produção de conhecimento. Entre a proliferação de híbridos - somos todos um misto de natureza e cultura - e o trabalho de eliminação desses híbridos - o esforço de assepsia com o qual lida, de modo geral, o processo de produção de conhecimento -, o autor nos interpela a todos: "Se a leitura do jornal diário é a reza do homem moderno, quão estranho é o homem que hoje reza lendo estes assuntos confusos" (2009: 8).

O trabalho de separar para organizar - gesto que, para além do jornal e do jornalismo, é próprio do pensamento moderno - está diretamente ligado ao esforço de eliminação dos híbridos; uma atitude que operacionaliza conhecimentos distanciados do mundo que experimentamos. É nesse sentido que os saberes, tal qual os assuntos, se apresentam confusos, pois para Latour, no próprio espaço do jornal, como também o é no mundo da vida, "toda a cultura e toda a natureza são diariamente reviradas [...]" (2009: 8).

É assim que, para este autor, fatos, poder e discurso - que diretamente nos remetem ao real, ao social e ao narrado - só se apresentam 
como separáveis à luz de disciplinas e procedimentos metodológicos que visam à explicação e à organização dos hibridismos. Fazendo referência aos assuntos geralmente abordados no jornal, Latour nos lembra:

O buraco de ozônio é por demais social e por demais narrado para ser realmente natural; as estratégias das firmas e dos chefes de Estado, demasiado cheias de reações químicas para serem reduzidas ao poder e ao interesse; o discurso da ecosfera, por demais real e social para ser reduzido a efeitos de sentido (2009: 12).

Tal problematização dá lugar a uma longa e densa reflexão sobre nossos modos de pensar, estar e narrar (n)o mundo. E é por este viés que o território palestino se apresenta como um desafio para a imprensa. Como separar os interesses econômicos e políticos dos imaginários coletivos e desejos que habitam um território em disputa? Como reportar a invasão e a ocupação da Palestina frente à certeza - ou ao uso do discurso religioso - de ser este gesto nada mais do que uma "volta à Terra Prometida"? Como dar a ver o conflito na complexidade que ele se apresenta diante das demandas de objetividade e tempo que regem o discurso jornalístico? Trata-se de perguntas que, em relação à imprensa, nos levam diretamente ao problema da representação.

Em "Falar para as massas, falar com o outro: valores e desafios do jornalismo" (in: França e Corrêa, 2012: 153-165), busco problematizar a imprensa, pensando-a na atualidade como mais um lugar possível de enunciação acerca do acontecimento. A partir de questões levantadas pela cobertura do conflito Israel/Palestina feita pelo repórter-quadrinista Joe $\mathrm{Sacco}^{37}$, e diante de tantos outros relatos

\footnotetext{
${ }^{37}$ Ver particularmente Sacco, 2000, 2005,2010.
} 
a que temos acesso a partir do próprio avanço tecnológico, é colocada em questão a condição de o jornalismo ser uma instância de enunciação midiática cujos valores legitimados, busco argumentar, sempre seguiram uma lógica externa às problemáticas da linguagem.

Por este viés, ao balizar dois conjuntos de experiências distintos - quadros histórico-culturais -, busco apresentar desafios que nos permitem considerar os modos de encenação da notícia (o lugar próprio da representação) como lugares possíveis de onde emerge uma diversidade de sentidos que viabiliza um processo de ressignificação de valores do/para o jornalismo. O primeiro deles, tomado por uma concepção do que seria falar para uma suposta massa é pautado pelo que podemos chamar de "paradigma informacional". No que se refere ao seu projeto enunciativo, este quadro coloca para o jornalismo um problema exclusivo: transmitir o que ele define como informação. O falar para é o propósito de referência deste quadro histórico-cultural que experimentamos, muito particularmente, até os anos finais do século XX.

Uma das características deste quadro, por exemplo, está na imprensa que particularmente se voltou para os princípios da objetividade, dando a esta proposição técnica um caráter ideológico no âmbito da profissão. Nas palavras de Schudson, "com a ideologia da objetividade, os jornalistas substituíram uma fé simples nos fatos por uma fidelidade às regras e procedimentos criados para um mundo no qual até os fatos eram postos em dúvida" (2001: 122). Esta imprensa, ao sustentar estratégias, epistemologias e técnicas, produziu um modo de falar que contribuiu para que ela própria se legitimasse como detentora de saber sobre os modos de produção do acontecimento.

Pensando a partir da narrativa e do problema da enunciação, os recursos estratégicos e técnicos (a objetividade e o uso de aspas, por exemplo) ou epistemológicos (o saber produzido a partir de um suposto distanciamento por parte de quem narra), exatamente 
porque produzem um modo de falar no jornalismo, foram (e têm sido) cruciais para sustentá-lo no seu lugar de legítimo enunciador de uma verdade. Foi assim que a estratégia da objetividade (Tuchman, 1999), transformada em componente ideológico, tornou-se crucial para fazer da linguagem um problema aparentemente resolvido.

Já o segundo conjunto de experiências a que me refiro recoloca em outros termos, para o campo e a prática do jornalismo, a problemática da linguagem. Caso pudéssemos definir cronologicamente o seu momento de instalação, diríamos que ele "nasce» primordialmente com / e a partir (d)o avanço tecnológico que torna possível a complexificação e o aumento das produções narrativas. Exatamente o mesmo que faz com que a questão da representação, enquanto problema do jornalismo, seja compreendida como um tiro saído pela culatra: o próprio avanço tecnológico e as demandas pela representatividade produzem múltiplos fazeres e narrares, tornando minimamente desejável a ideia de que a comunicação e, certamente, o jornalismo sejam espaços nos quais possam coexistir sujeitos em relação (França, 2006).

Se no quadro anterior, compreendia-se representação como resultado de uma cópia da realidade, ou uma mímese, no sentido aristotélico - um aspecto teórico bastante preciso para o jornalismo em questão, pois o resguarda em sua função primordial de referencialidade e de relação direta com a verdade do fato - no quadro histórico-cultural que hoje experimentamos, entra em questão uma percepção mais voltada para o reconhecimento de uma multiplicidade possível de representações acerca do acontecimento. Na concepção de Rancière, trata-se hoje de um outro regime no qual o estético é tomado como referência, uma outra visão de mundo, menos submissa à "regulagem representativa do visível e da palavra (...), à identificação do processo de significação à construção da história" (2012: 133). Para este autor, o regime atual, que ele chama de "estético", "abole a circunscrição 
mimética que separava a razão das ficções da razão dos fatos, a esfera da representação de outras esferas da experiência" (2012: 133) ${ }^{38}$.

Por este viés, os dias atuais, para a imprensa, deflagram a premência de considerarmos a linguagem como um problema, e seu reconhecimento implicaria pensar que não se trata mais de um falar para, mas muito mais fortemente, da demanda por um falar com. Em relação às diferenças que a Comunicação produz, e com as quais ela precisa conviver, Marcos (2007) tece considerações importantes, levando em conta o "relacional" como um desafio hoje "incontornável". Para esta autora,

\begin{abstract}
A dimensão relacional, tensional, simbólica e mediada da experiência confere à Comunicação um lugar de princípio. No âmbito epistemológico das Ciências da Comunicação, o modo de ser do sujeito face ao mundo, aos outros e a si próprio desenha um quadro de reflexão incontornável. Incontornável porque instável, sem contornos pré-definidos. Incontornável porque indispensável, sem alternativa. (2010: 244)
\end{abstract}

É por este viés que nossa argumentação central gira em torno do fato de que para o jornalismo, hoje, a problemática da representação assume um valor preponderante tanto em termos teóricos quanto práticos; é neste conjunto de experiências e problemas que o "como falar com" se torna uma pergunta essencial.

\footnotetext{
${ }^{38}$ Rancière (2012) toma a arte, no sentido amplo, como parâmetro para pensar o que ele chama de diferença entre o "regime representativo" e o "regime estético". É preciso levar em conta este fato ao fazermos a passagem da reflexão deste filósofo para os problemas da imprensa e do jornalismo. Este aspecto, entretanto, não deve inviabilizar a transposição dos problemas de um dito sistema para outro. O que Rancière faz notar em relação à representação e aos sistemas que produzem linguagem no mundo atual é amplo o bastante para nos apoiar na crítica que busco fazer em relação à imprensa. Para Rancière, antes de tudo, representação é um problema de linguagem, o que no âmbito desta reflexão nos é crucial.
} 
Sob essa perspetiva, as problemáticas referentes a um falar com o outro, no âmbito da imprensa, fazem parte de um quadro abrangente no qual, em diversos campos e saberes, práticas e conhecimentos são reavaliados. São outros valores e desafios que entram em cena, dada a própria condição de ser o jornalismo uma prática sócio-cultural que, inevitavelmente, sofre alterações ao longo do tempo. Nesse sentido, coloca-se a problemática da representação no âmbito dos discursos e das narrativas jornalísticas como parte de um jogo de reconfiguração do saber, o que implica, necessariamente, a busca por práticas e instrumentais teóricos e metodológicos que minimamente deem conta das demandas atuais.

A crítica que, de modo geral, se faz à imprensa em relação às coberturas simplistas e reducionistas precisa ser colocada nesses termos. No quadro histórico-cultural que ora experimentamos, as teorias e saberes que se fizeram hegemônicos, diante das mudanças em curso, parecem ter se convertido em frágeis pilares. E é neste conjunto de problemas que o olhar lançado ao jornalismo pelo viés da narrativa adquire um papel proeminente. Trata-se antes de tudo de pensá-lo pelo viés da linguagem - «o que acontece na narrativa é a linguagem", disse Barthes (1988: 115) - e, mais ainda, de considerá-lo parte de uma dimensão discursiva ampliada, já que a narrativa, inevitavelmente, acolhe princípios que extrapolam as ordens dos discursos (Ricoeur, 2005; Resende, 2011a).

Por este viés, assume-se a linguagem como base epistêmica para pensar o jornalismo, colocando em cena a problemática da enunciação ${ }^{39}$. É a fala como gesto, se quisermos assim pensar, que é evocada como um dos problemas centrais do que hoje conhecemos como

\footnotetext{
39 Para Michel de Certeau (2000), a "virada da modernidade" consiste em nos fazer entender que, com a morte de Deus, cabe ao homem produzir a fala. Para este autor, este é o momento em que a problemática da enunciação se torna o problema da comunicação.
} 
jornalismo. Nesse sentido, parece-nos importante as considerações de Mayra Gomes:

antes de registrar, informar, antes de ser colocado pelas condições que o caracterizam, por exemplo, periodicidade, universalidade, atualidade, difusão [...] o jornalismo é ele próprio um fato de língua. Seu papel e sua função na instituição social implica o de organizar discursivamente, o que, aliás, é a prática jornalística por excelência (2008: 19).

Como prática social-discursiva, este jornalismo do qual falo, é um "conjunto de problemas, orientações, intenções e dizeres que, de forma inseparável, dá a ver o possível do mundo" (Resende, 2011: 128). Ele enuncia, representa e media outras práticas - culturais, sociais, políticas, econômicas - inscritas no cotidiano. E somente assim, ressignificado, se pode compreendê-lo a partir de suas narrativas, plenas de aprisionamentos e potencialidades. Pois são elas, as narrativas, que nos interpelam a um olhar pela linguagem, o que necessariamente excede o esforço da produção de uma técnica.

\section{A Palestina no cenário global contemporâneo}

$\mathrm{Na}$ introdução de Nação e Narração, Homi Bhabha reclama de uma "perda" por não ter sido incluído no livro por ele organizado um ensaio sobre aqueles "que ainda não encontraram a sua nação” (1990: 8). Os palestinos, para Bhabha, são esses cujas vozes haveriam de estar "entre as imagens exorbitantes do espaço-nação em sua dimensão transnacional" (1990: 08). Bhabha conclui sua reflexão com as mesmas perguntas de Said (que lemos no início deste artigo), fazendo-nos entender que ele não está somente lamentando a perda do que seria mais um capítulo do livro, mas, 
fundamentalmente, constatando a dúvida sobre que tipo de nação a Palestina é ou deixa de ser.

Além de a Palestina ser hoje uma fonte constante de notícias para a imprensa e a TV, as narrativas sobre a Palestina e os palestinos (produzidas por eles ou não) têm aumentado em número, e, por conseguinte, se diversificado em termos de formas, vozes e suportes comunicacionais. Entretanto, certamente desde quando Bhabha e Said já discutiam os problemas daquele território, os conflitos vividos pelos palestinos só têm se exacerbado.

Partindo de uma perspetiva histórica do conflito Israel/Palestina, Rashid Khalid argumenta que "a dura tarefa dos palestinos para cruzar fronteiras, limites e barreiras dentro e fora da sua própria terra (...) não diminuiu" nos últimos $20 \operatorname{anos}^{40}$. Seja em relação à progressiva perda do território, ao aumento no número de palestinos sendo presos e assassinados ou ainda ao crescimento no número de campos de refugiados na região, os séculos XX e XXI testemunham um conflito dramático e sem fim no qual, não há dúvida, a Palestina e os palestinos são o lado perdedor.

Na medida em que as políticas de ocupação do território recrudescem e são implementadas, os palestinos não têm outra opção senão viver confinados ou abandonar sua terra. Intervenções políticas e econômicas por parte de Israel, amparadas pelos Estados Unidos, vários países europeus e alguns dos países árabes limitam o ir e vir dos que ainda vivem na região. Além disso, o aumento dos problemas em relação às políticas de relações internacionais devido aos conflitos internos - dos quais disputas entre o Fatah e o Hamas são exemplos - são alguns dos problemas que tornam hoje ainda mais complexa a questão da Palestina.

\footnotetext{
${ }^{40}$ Tradução livre do original: "(...) the travails of Palestinians in crossing boundaries, borders, and barriers within and without their homeland (...) have not diminished." In: Rashid, 2010: xxiv.
} 
De uma perspetiva cultural, entretanto, nota-se também que desde o final do século XX, o mundo tem experimentado uma mudança significativa e um avanço tecnológico bastante singular no que se refere à diversificação de aparelhos eletrônicos através dos quais as histórias são contadas e disseminadas. Há ainda filmes, documentários e programas de TV, por exemplo, que também contam histórias do conflito, muitas vezes, de forma diferenciada da que estamos habituados a ler nas chamadas "mídias hegemônicas e tradicionais". Hoje, talvez mais que nunca, temos acesso a várias narrativas sobre este conflito de formas distintas através dos mais diversos meios.

Longe de pensar que seja este o fim dos oligopólios das mídias e ainda que todos os cidadãos têm o mesmo acesso à produção e à leitura dessas narrativas, uma certa pulverização dessas histórias, e portanto dos saberes sobre o conflito, não pode ser desconsiderada. Seja através de telefones móveis ou redes sociais, por exemplo, com narrativas em primeira pessoa e informação vinda direta do local do conflito, partindo inclusive daqueles que o experimentam no cotidiano, tais narrativas, para o bem e para o mal, alteram a nossa compreensão do conflito propriamente dito (Resende e Paes, 2011b).

Para entender a Palestina na sua contemporaneidade e nos seus gestos de resistência, Tawil-Souri associa e contrapõe a ideia de uma expansão midiática com a redução espacial do território palestino. Segundo a autora, este aspecto forma um relevante "campo de contradições", pois junto com "repressão, obstrução, controle, vigília e silenciamentos", é somente agora, desde os anos 90, que "os palestinos que vivem nos Territórios Ocupados têm a 'liberdade' para produzir mídia". ${ }^{41}$ A ênfase que a autora dá à palavra "liberdade” certamente chama atenção para o fato de que a produção de

\footnotetext{
${ }^{41}$ Tradução livre do original: "repression, obstruction, control, surveillance and silencing, it is since the 1990s that Palestinians in the Territories have (...) had the 'freedom' to create media". Tawil-Souri, (2012: 145).
} 
narrativa, principalmente nos Territórios Ocupados, ainda é uma questão problemática. Porém, após a Nakba (1948), o que Tawil-Souri reconhece é que este é um momento importante para os palestinos, que, de muitas maneiras, vêm sendo capazes de contar as histórias da sua luta e das suas vidas cotidianas.

Nesse sentido, nota-se o aumento da produção narrativa não somente no número elevado de festivais de cinema da Palestina, com produções locais bastante expressivas, como também no enorme volume de weblogs dedicados a discutir a questão palestina, além da grande variedade de livros (literários e acadêmicos) e periódicos com material publicado sobre e pelos palestinos. Ecoando Tawil-Souri, contextualizar a Palestina no cenário global contemporâneo, contrastando este aumento dos produtos culturais com o acirramento e a maior gravidade das questões políticas e econômicas efetivamente enfatiza os signos de resistência que marcam as vidas dos palestinos. Narrar - sugiro - é criar cultura, e este gesto, no caso da Palestina, ainda de acordo com Tawil-Souri, é uma "forma de resistência política" (2012: 139).

Deste ponto de vista, abordar o problema da Palestina pelo viés da narrativa não se configura tão-somente como um instrumento metodológico, mas também, e principalmente, como um operador conceitual que evidencia uma forma estética e política de criar resistências. Nos seus estudos sobre o tempo e a narrativa, Ricoeur aponta nesta mesma direção ao nos fazer entender que a narrativa é o espaço no qual a desordem se faz visível. Nas suas palavras, "a tessitura da intriga nunca é o triunfo da ordem" (2010: 13). Ao contrário, a narrativa histórica ou ficcional é também o lugar em que o humano experimenta as disjunções temporais, é onde e quando a linearidade imaginada encontra os seus contrapontos. Para Ricoeur, narrar é estar no mundo, um ato intrinsicamente humano, feito de continuidades e rupturas. O que a narrativa faz, ele diz, é "tentar colocar consonâncias onde só pode haver dissonâncias" (2010: 112). 
Alguns palestinos estão hoje confinados em uma terra que é deles, mas sobre a qual não têm direitos. Uns vivem em vilas constantemente sitiadas e vigiadas, como em West Bank, Gaza e Jerusalém, alguns em outras cidades em franco processo de apagamento, como Jaffa e Haifa, e há ainda os que vivem exilados em outros países e/ou em campos de refugiados. É assim que se constrói hoje a experiência de ser palestino, ela é multi-geográfica. Não se trata somente de uma questão de dispersão, mas, de uma maneira muito mais complexa, de uma experiência de multi-localidades que se vive simultaneamente com o sentimento de não caber em espaço algum. ${ }^{42}$

Diante de tamanha complexidade, a problematização da questão da Palestina pelo viés da narrativa pode nos ser muito útil no processo de desvelamento das camadas de padrões hegemônicos que geralmente encobrem as experiências e as vidas dos que habitam aquele território. Narrar a Palestina é uma forma de representar o seu problema, tornando-o vivo perante o outro; um gesto político de intervenção nas dinâmicas sócio-culturais. Said corrobora dizendo que "o poder de narrar ou de impedir que outras narrativas se formem e apareçam é muito importante para a articulação cultura/ imperialismo, constituindo uma das mais importantes conexões entre eles". ${ }^{43}$

Um elo político/estético, portanto, é o que se nota claramente na produção de narrativas em torno de conflitos de natureza territorial, como é o caso do conflito Israel/Palestina. Matar \& Harb, ao discutirem conflito e narração no Oriente Médio, chamam atenção para o fato de que "em nenhum outro lugar a disputa pela imaginação, construção e narração de conflito, assim como seus sentidos e

\footnotetext{
${ }^{42}$ Considerações feitas por Tawil-Souri na Conferência "Palestinian Screens of Struggle", que aconteceu durante o Palestine Film Festival (School of Oriental and African Studies (SOAS), University of London, Maio/2013).

${ }^{43}$ Tradução livre do original: "the power to narrate, or to block other narratives from forming and emerging, is very important to culture and imperialism, and constitutes one of the main connections between them". In: Said, 1994: xiii.
} 
centralidade no cotidiano das pessoas, é mais contundente (...) do que na Palestina e no Líbano", já que são, além de tudo, disputas que colocam em questão noções de "espaço, identidade, discurso, imagem, narrativa" ${ }^{44}$.

Deste modo, interpretar e abrir outras leituras possíveis em relação ao conflito vivido na Palestina significa escavar a vida cotidiana do palestino, este que, sitiado e coagido, vive também em constante processo de deslocamento, lutando para sustentar e, ao mesmo tempo, (re)construir tanto a nação que hoje lhe é possível como aquela pela qual ele anseia. Como dar a ver, no âmbito da representação, os interesses e desejos que ali se instalam? Um desafio enorme para um tipo de imprensa que tradicionalmente se esmera em pautar-se por grandes narrativas, não só alijando-nos do processo de sedimentação de camadas de estereótipos como também deixando de lado aquilo que parece menor diante de um conflito de natureza tão absurda.

\section{Produção de estereotipias e modos de resistir pela linguagem}

Jean Genet passou dois anos morando em um campo de refugiados palestino, na Jordânia dos anos 1970, e mostrava-se já preocupado com o processo de produção de imagens cujo intuito era transmitir a realidade. Referindo-se ao uso dos significantes terrorismo, holocausto e genocídio, em relação ao conflito, Genet dizia: “'É bastante inteligente da parte de Israel levar a guerra ao coração da linguagem" ${ }^{45}$

\footnotetext{
${ }^{44}$ Tradução livre do original: "nowhere is the competition over the imagination, construction and narration of conflict, as well as its meanings and its centrality to people's everyday lives more compelling, since in the Middle East, these competitions, above all, put into play concepts of "space, identity, discourse, image and narrative". In: Matar e Harb, 2013: 4.

${ }^{45}$ No original: "it is very smart of Israel to carry the war right into the heart of vocabulary" (Genet, 2003: 374).
} 
O cenário midiático global, hoje, levanta - ou pelo menos joga luz sobre - a questão dos sentidos que os significantes adquirem nas narrativas sobre o conflito. Em uma tal guerra de narrativas, na qual os sentidos são disputados "no coração da linguagem", atores hegemônicos - como é o caso de Israel - sempre começam vencendo; eles detêm o discurso dominante e os aparatos que sustentam sua causa ${ }^{46}$. Por esta razão, o terreno torna-se vulnerável e bastante propício à sedimentação de estereotipias e binarismos.

"Portrait of Palestine" ${ }^{47}$ pode nos ajudar a entender o processo de formação de camadas de narrativas dominantes acerca do conflito e da região. No escopo deste artigo, ele nos serve como um exemplo fundante, pois nele se inscreve as grandes narrativas que seguem, ainda nos dias de hoje, pautando muito do que se entende pelo conflito. A narrativa se inicia traçando um perfil religioso dos palestinos, segundo o narrador, uma mistura de muçulmanos, samaritanos, judeus e cristãos. O documentário dá ênfase, desde o começo, a uma narrativa bíblica na qual a cidade de Bethlehem é apresentada como um local em que há uma "igreja católica romana chamada 'Igreja de Todas as Nações'".

Com uma narrativa dividida basicamente em duas partes, assistimos primeiro à "Palestina do passado - um lugar comum onde o homem jamais tocou, habitado por humildes artesãos e mulheres que vestem roupas da Europa medieval". São pessoas que moram em "cidades muito calmas" - como se descreve Jerusalém -, e "que nada querem além de paz”. Já na segunda parte, entretanto, chamada

\footnotetext{
${ }^{46}$ Esta reflexão se deve aos trabalhos de Bakhtin e Foucault, basicamente a partir do pensamento do primeiro deles sobre o discurso como "campo de batalha social" (ver Mikhail, 1981), e a preocupação de Foucault em relação à preponderância que o conhecimento e o discurso disciplinar tem sobre a representação. (ver Foucault, 2002).

${ }^{47}$ Produzido em 1947, um ano antes da Nakba, pela Anglo-Scottish Pictures, o documentário de 16 minutos pode ser visto em http://www.colonialfilm.org.uk/node/2477 (acesso em outubro/2013). Todas as falas deste documentário foram literalmente transcritas e são, portanto, livres traduções.
} 
"o caminho para o futuro", nota-se uma mudança substancial: uma música mais agitada e uma narração mais densa anunciam a chegada da modernidade.

A narrativa prossegue enaltecendo a presença árabe na região, dizendo, por exemplo, se tratar de uma cultura mundialmente conhecida desde a Idade Média, mas com uma proposta clara de sustentar a diferença entre o passado que a Palestina estaria deixando para trás e suas prospeções para o futuro. "Jovens árabes”, diz o narrador, agora buscam "reviver suas tradições” enquanto se tornam "cidadãos do mundo moderno". Um tipo de modernidade, entendemos pela própria narrativa, que viria com a implementação do Mandato Britânico e com os colonizadores sionistas que já trabalhavam na terra fazendo uso de uma "moderna maquinaria”. "Seja qual for o futuro político da Palestina”, diz o narrador, "o Governo Britânico está determinado a fazer com que a terra comum aos árabes e aos judeus se beneficie dos privilégios da ciência Ocidental". Desse modo, e logo após nos mostrar a moderna arquitetura de Jaffa e Jerusalém, a Universidade Hebraica e o novo Hospital Judaico, a única dúvida com a qual o narrador nos deixa é o quanto árabes e judeus "poderão viver juntos e em paz”.

"Portrait of Palestine", com um título já bastante simbólico, produz uma narrativa que unifica significantes tais como nações / Ocidental / modernidade / Sionismo / benefícios. Através desta narrativa fílmica, entendemos que a novidade - o progresso e o desenvolvimento - viria daqueles que lutam para fazer a Palestina crescer e ser o que «Sua terra sempre prometeu". Além disso, aprendemos que o futuro não somente virá das mãos dos judeus e dos Sionistas, como também pelo conhecimento de (e compromisso com) um tipo de modernidade inscrita em um Ocidente imaginado. De várias formas, esta narrativa carrega já estratégias discursivas hegemônicas fundantes usadas a favor da ocupação hoje em curso. 
Como "retrato" de um lugar, esta narrativa inventa um futuro, contestando a Palestina do passado e reiterando-a como incapaz de acompanhar as demandas do progresso. Na sua estrutura, todas as grandes narrativas - religião, modernidade e progresso, por exemplo - se tornam parte da Palestina ali representada. Além de reforçar uma compreensão binária do conflito que já ali se instalava o arcaico ou o moderno, o religioso ou o secular -, nesta narrativa o discurso sionista é acobertado sob as perspectivas das promessas do Ocidente. Um relato exemplar, queremos sugerir, pois ajuda a fundar sentidos que também hoje vemos disseminados em meios de comunicação hegemônicos e em outros sistemas de representação. Esses que produzem graves estereotipias e contra os quais a Palestina e os palestinos também têm procurado lutar.

Todorov nos lembra que "a narrativa está necessariamente inserida num diálogo do qual os homens não são apenas o objeto, mas também os protagonistas." (2009: 86). Nesse sentido, um contraste com o retrato construído em "Portrait of Palestine" seria a fala de Azzouni, em entrevista concedida ao Electronic Intifada ${ }^{48}$ : "Eu não reconheço mais a cidade de Jerusalém, aquela na qual eu um dia morei". Azzouni é palestina, não mora mais em Jerusalém, e é através do seu relato que também sabemos dos tempos disjuntivos inscritos na sua experiência, em relação, particularmente, ao que a cidade de Jerusalém é hoje e o que ela foi no passado.

Sua fala nos diz ainda das inúmeras restrições a ela impostas pelo Estado de Israel em relação ao seu direito de ir e vir. Em outras palavras, através deste relato sabemos que não só Jerusalém vive uma disjunção temporal como também entendemos que este é o aspecto que molda a experiência de Azzouni. Sua família despedaçada assim o é porque ela não pode mais morar na cidade que marca e dá

\footnotetext{
${ }^{48}$ Entrevista completa em: http://electronicintifada.net/content/israels-residency-regime-causes-silent-transfer-jerusalem/12814 (acesso outubro/2013)
} 
sentido à experiência que ela um dia viveu. É a partir desse desacerto que Azzouni se constitui, ela mesma, como deslocada no tempo e no espaço, pois ela própria é parte de uma família absolutamente fragmentada:

dois são agora cidadãos franceses, eu sou jordaniana - e, como uma palestina, não autorizada a requerer cidadania jordaniana para o restante da minha família - e outros dois são cidadãos que não pertencem a Estado algum. É muito chocante, mas esta é a nossa Terra.

Se entendemos o conflito "entre os palestinos e o Sionismo como uma luta entre uma presença e uma interpretação, sendo que os primeiros constantemente aparecem subjugados e erradicados pelo segundo" ${ }^{\prime 9}$, ler a Palestina e as experiências dos sujeitos envolvidos no conflito, e que portanto sofrem suas consequências, é fundamental para nos revelar a complexidade que ali se inscreve. Quando o fluxo dominante insiste em se organizar a partir de binarismos e de narrativas totalitárias, por exemplo, as religiosas, os aspectos relativos aos desdobramentos e às contradições que o conflito produz tornam-se armas muito significativas. Eles são modos de resistir pela linguagem, pois nos ajudam a reinterpretar o conflito, jogando luz sobre sujeitos, modos de vida e temas geralmente obliterados pelos discursos do poder.

No microscópico e no ordinário - no elementar do cotidiano estão camadas, muitas vezes acobertadas pelas grandes narrativas, que precisam ser constantemente escavadas e desveladas. É fundamental produzir imagens - representações - que se contraponham às totalidades e aos absolutos. Os tempos disjuntivos que habitam a

\footnotetext{
${ }^{49}$ Tradução livre do original: "if we understand the conflict between Palestinians and Zionism as a struggle between a presence and an interpretation, [by] the former constantly appearing to be overpowered and eradicated by the latter". Said, 1992: 8 .
} 
Jerusalém de Azzouni, por exemplo, tornam-se elementos relevantes, pois nos ajudam a ressignificar a cidade supostamente dividida entre o velho e o novo, entre o moderno e o tradicional.

Em material publicado no Brasil - uma reportagem para a Revista Piau $^{50}$ - Flávia Castro faz uma espécie de diário, colocando em cena duas das narrativas centrais que vigoram no conflito Israel/Palestina. De um lado, israelenses certos de que o território é deles por direito, do outro, palestinos, seguros da violação do seu direito de viver na própria terra. O caminho que a autora da reportagem escolhe para mostrar essas "duas narrativas", como ela mesma chama, não consiste - e isto é muito importante - em simplesmente apontar, ou mostrar, que elas existem.

A própria escolha de fazer um diário, forma tão particular para a produção de relatos do cotidiano, é já relevante, pois ressalta uma experiência com o presente imediato, sem a demanda por uma explicação ou por uma conclusão acerca do lugar para o qual nos levaria o conflito. Afinal de contas, todo diário precisa do dia seguinte para que o(s) acontecimento(s) se desdobre $(\mathrm{m})^{51}$.

Além disso, ao narrar em primeira pessoa, Flávia Castro se desloca da perspetiva de autoridade que tal procedimento de antemão lhe garantiria, pois deixa claro a sua própria dúvida quanto ao que vai encontrar.

11 DE DEZEMBRO, QUINTA-FEIRA. Estou no Aeroporto Ben Gurion, em Tel-Aviv, na fila da polícia. Ensaio mentalmente todas as respostas que me ocorrem às perguntas que os agentes

\footnotetext{
${ }^{50} \mathrm{Em}$ http://revistapiaui.estadao.com.br/edicao-103/diario-flavia-castro/entre-duas-narrativas (acesso em agosto/2015)

${ }^{51} \mathrm{Na}$ invasão que o Iraque sofreu em 2003, Sérgio D'Avila, no jornal Folha de São Paulo, faz uso desta mesma forma. O jornalista publica durante um mês a coluna "Diário de Bagdá", que hoje é um livro: Diário de Bagdá-A guerra do Iraque segundo os bombardeados, de Sérgio Dávila e Juca Varella, DBA, São Paulo, 2003.
} 
de segurança certamente farão. Amigos me preveniram: "Não se assuste, é assim com todos. Podem até te levar para uma salinha..." Verifico pela décima vez meus documentos. A fila avança.

O ensaio mental para que se tenha as respostas na ponta da língua e o ato insistente de verificar os documentos, gestos tão comumente conhecidos como próprios de quem está em estado de tensão ao entrar em qualquer país, denotam, de partida, o fato de que é do inesperado que esta narrativa vai tratar. A autora deste modo abre para nós o desconhecido no qual ela mesma entra, a partir de uma experiência que nos é comum a todos. São sensações a que temos acesso através de um relato cujo tempo é a própria medida do acaso e da experiência: "Menos de quinze minutos depois de eu ter tocado o solo, desmoronava minha primeira ideia pronta sobre Israel. Afinal, não foi difícil entrar".

A autora prossegue descrevendo o caminho até o apartamento em que ficará hospedada. A cidade de Jerusalém, para onde Castro se dirige logo que sai do aeroporto de Tel Aviv, longe de ser apresentada pelos seus já conhecidos locais de peregrinação, chega até nós através das barreiras que ela enfrenta:

\footnotetext{
Minha imaginação paranoica não resiste à ideia de que no momento em que eu estiver cruzando a cancela uma ressonância magnética revelará todos os segredos do meu corpo, e até de meus pensamentos.
}

Desse modo, distante da narrativa religiosa que por princípio nos tomaria pelo minimamente conhecido, através do corpo da narradora, acessamos já os entraves que circundam uma cidade sitiada. Chegamos ao aeroporto em Israel, pegamos a estrada, vemos "tanques verde-claros estacionados no acostamento" e nos deparamos logo com as disputas e os limites que o território vive. 
Para Bhabha, o narrar é que torna possível o gesto de colocar em cena camadas de "restos, retalhos, pedaços da vida cotidiana", partes que, para este autor, "são insistentemente transformadas [por narrativas totalitárias] em signos coerentes de uma suposta cultura nacional" ${ }^{\text {. A }}$. tensão que experimentamos, as cancelas e os tanques que cruzamos com Flávia Castro, ou os tempos disjuntivos que também conhecemos no relato de Azzouni, no escopo das grandes narrativas que formam e permeiam o conflito Israel/Palestina, são para nós os retalhos, ou os pedaços de um cotidiano, elementos fundamentais para uma leitura menos determinada - e menos determinista - acerca daquele território.

Sob essa ótica, a reportagem de Flávia Castro se desloca das narrativas totalitárias exatamente porque ela atravessa o conflito, muito mais do que o define ou explica. A visita ao Museu do Prisioneiro Palestino, seguida por uma outra, ao Museu do Holocausto, abre contrapontos importantes, pois delineiam, desde já, as duas narrativas a que a autora se refere:

17 DE DEZEMBRO, QUARTA-FEIRA - Da Palestina fomos direto para um dos mais importantes memoriais do Holocausto, o Yad Vashem, localizado numa colina nas proximidades de Jerusalém. Somos recebidos por Avraham Milgram, simpático historiador brasileiro que trabalha lá há muitos anos. Ele nos diz: 'Cada museu do Holocausto tem o seu ponto de vista. Aqui, toda a narrativa é construída a partir do ponto de vista da vítima.' Como que em continuação do museu, vejo Jerusalém. Israel, 'a Terra da Salvação' para uns, 'a Terra Prometida' para outros. O fim da narrativa é claro. Estamos nela. Penso novamente no Museu do Prisioneiro Palestino.

\footnotetext{
52 Tradução livre do original, “(...) the scraps, patches and rags of daily life are repeatedly turned into the signs of a coherent national culture”. (Bhabha, 2006: 209).
} 
A simplicidade de um, a sofisticação do outro. Os dois têm uma coisa em comum: o lugar da vítima, no centro das respectivas narrativas, como ponto de partida para pensar o seu lugar no mundo.

Todos são vítimas, esta é a regra que define os modos de ser nessa geografia violentada; uma afirmativa absolutamente contestável diante da ocupação e da não equiparidade ${ }^{53}$ que rege as forças que atuam no conflito. Pensamos: se o que há em comum entre o palestino e o israelense é pensar o mundo a partir do seu lugar de vítima, encontramo-nos no cerne do imbróglio: qual das vítimas tem mais ou menos direito a este lugar?

Flávia Castro, neste instante, toca no que talvez seja o mais acentuado dos problemas: a questão territorial. E quase um mês depois, ela volta ao tema: “13 DE JANEIRO, TERÇA-FEIRA - Para eles, o único ponto de partida e de chegada possível para pensar o mundo é a própria tragédia”. E ainda nesse mesmo dia, ela conta:

Numa livraria, vejo um mapa da Palestina de 1948, igual ao que o guia do museu palestino e o colono [no Museu do Holocausto] usaram para suas narrativas. Entro e compro, talvez numa esperança vã de que o traçado das fronteiras me ajude a dar alguma concretude às mil questões que me assolam.

Esforço vão o da narradora, pois não há mapa ou linha fronteiriça que consiga explicar a divisão entre o território palestino e o ocupado. O trauma ou a crença cega, em cada um, é o que traça o seu mapa; é o que desenha a sua fronteira.

\footnotetext{
${ }^{53}$ Ilan Pappé (2010) faz uma crítica contundente à mídia, de modo geral, dizendo que para narrar o conflito na região, ela parte de um injusto "paradigma de equiparidade", o que pressupõe uma igualdade entre o Estado de Israel e a Palestina.
} 
Em um território cujo povo experimenta o dilema de ter sido o que hoje não é ou de ter vivido onde hoje não se pode viver, as histórias adquirem um papel crucial: elas representam o esforço de recuperação/sustentação de uma memória e/ou a própria construção do sentido da terra. É assim que nas narrativas acerca deste conflito, de forma muito marcante, a disputa pela fala verdadeira se traveste, ela mesma, na disputa pela própria narrativa.

Através do diário de Flávia Castro, colocamo-nos diante do que, neste conflito, não se consegue medir; é esta a disputa a que temos acesso. O humano que ali habita, de algum modo, insiste em se fazer presente, em estado de conflito. Para a autora, foram 38 dias dos quais ela ainda não falou "dos tomates-cereja, do vinho e das romãs. (...) do mercado, da beleza do deserto". Mas quem a acompanhou no relato, ficou com as experiências e os lugares de que o conflito se constitui.

\section{Conclusão}

Sabemos que a linguagem, e particularmente o modo como a narrativa a pressupõe, assume um caráter eminentemente semiótico, ela é lugar de produção de sentidos, ela não se exaure no dizer, ela é o infindável jogo do significante. Nas palavras de Heidegger, ela é "mais poderosa e por isso [tem] mais peso do que nós mesmos" (2003: 98). E é por este caminho que se deve também entender que olhar a imprensa a partir da narrativa pressupõe colocar em questão uma "tarefa hermenêutica", pois é o jogo mimético entre o mundo do autor, o da obra e o do leitor que evidencia o processo de produção de sentidos (Ricoeur, 2010). Um processo que, inevitavelmente, produz faltas e diferenças.

Em entrevista concedida ao Jornal O Globo (14/01/2012), Bhabha se refere ao poder da narrativa enquanto espaço no qual sentidos e diferenças podem ser notados. Segundo o autor, 
a verdadeira natureza da narrativa sempre levanta a questão: se as coisas fossem diferentes, qual poderia ser o resultado? Se eu não fosse eu mesmo, como veria o mundo? (...) Questões sobre alteridade, alternância e contrafatualidade estão no centro do projeto (...) cultural, e é por isso que penso que [o olhar sobre a narrativa] nos ajuda a sobreviver.

Assim, em suas formas factuais $e$ ficcionais, binárias $e$ não, a narrativa é invariavelmente constitutiva de um processo político e estético de produção e ressignificação de sentidos sobre o mundo. E é por este viés que o esforço de compreender o jornalismo através de suas narrativas ajuda-nos a problematizar e criticar seus princípios. A menos que aceitemos que transmitir informação seja sua única função, não há como pensá-lo, através da narrativa como problema (Resende, 2011), sem colocarmos em pauta as insuficiências que a linguagem produz. É do caráter da linguagem não dar conta do todo; é próprio de qualquer sistema de representação significar a falta. Portanto, pelo olhar da narrativa, o jornalismo, a despeito do seu esforço de clareza e precisão, não passaria impune pelos desígnios da linguagem.

A perspetiva sobre o conflito Israel/Palestina a que temos acesso através do relato de Azzouni ou do diário de Castro - esta que torna visível os conflitos dentro do conflito - não comporta o todo e portanto não invalida um outro modo de narrar, mais objetivista, que também guarda o potencial de encenar aspectos importantes que constituem aquele acontecimento. Aqui não está em questão a maneira correta ou não de representar, o que está em jogo é o modo de falar da coisa sobre a qual se fala. Estamos, na verdade, perguntando: em que medida e de que maneira é possível outras formas de narrar o conflito? Edward Said, ao argumentar sobre as formas de representação do colonizado, reitera que "as narrativas são de uma forma ou de outro política e ideologicamente permissíveis" (1989: 
222), tudo dependeria dos modos como os tópicos e os sujeitos nelas são inscritos.

$\mathrm{Na}$ chamada "grande imprensa", na maioria das vezes, as narrativas a que temos acesso sobre esta geografia violentada são tão controladas pelas instâncias políticas e econômicas que a dominam, que só vemos imperar um discurso binário e dicotômico, pouco afeito às nuances do conflito. Sob essa ótica, os restos que aparecem no relato de Azzouni ou no diário de Castro funcionam como um contraponto essencial. Ali estão narrativas que carregam e guardam a potência de refazer-se em outras, de desdobrar-se. Nas palavras de Michel Serres,

\begin{abstract}
A formação de uma narrativa dá provas (...) de uma tensão incessante entre a necessidade de utilizar formas preestabelecidas, um formato, para poder comunicar de maneira confiável e uma equivalente obrigação de quebrar, de refazer essas formas porque as circunstâncias contingentes vêm restringi-las e a repetição pura e simples não comporta nenhuma mensagem. (2015: 191)
\end{abstract}

No atual quadro histórico-cultural em que nos encontramos, reconhecer esta ambiguidade que conforma a narrativa significa referendar o amálgama estética/política (Rancière, 2012). E desse modo, é à luz de um paradigma relacional que se precisa trabalhar contra a sedimentação das estereotipias, escavando os processos em que conflitos de longa duração se inscrevem e produzindo narrativas que falem também do que constitui os poderes que os engendram. No caso da Palestina, para Edward Said,

É preciso seguir contando histórias de forma contundente e tão insistentemente, e de tantos modos quantos forem possíveis, para chamarmos atenção, pois sempre há o medo de que a Palestina possa desaparecer (2003: 187). 
O esforço de apagamento do território palestino tem causado danos irrecuperáveis em termos humanos e físicos. Porém, ele não tem efetivamente produzido o seu desaparecimento. Ainda que na forma de uma geografia violentada, a Palestina, como nação, segue se reinventando da maneira que pode, e hoje, mais que nunca, além da resistência dos próprios palestinos, são as narrativas que a mantém viva. É sob esta perspetiva que também tratamos do território palestino - e do conflito ali instalado - como um desafio para a imprensa. Uma geografia exaurida esgarça os domínios do pensamento e da linguagem, tornando irrepresentável o próprio fato de que a geografia é vítima. E neste caso específico, é o próprio que se torna indecifrável.

Sabemos que para a imprensa esta pode não ser das tarefas a mais simples. Porém, mais que transmitir, esta reflexão sugere que hoje representar, nos termos aqui discutidos, é uma de suas funções essenciais. Por este viés, é preciso, mais que nunca, o esforço de narrar essa geografia violentada a partir dos efeitos político-culturais que afetam as experiências de quem vive o conflito. Talvez através desses espaços liminares, retomando a angústia de Michel Serres na epígrafe deste artigo, possamos nos fazer atentos a uma narrativa que seja mais próxima do homem.

\section{REFERÊNCIAS BIBLIOGRÁFICAS}

BAKHTIN, M. (1981). The dialogic imagination. Austin: University of Texas Press. BARTHES, R. (1988). O rumor da língua. São Paulo: Brasiliense.

BENETTI, M. e LAGO, C. (orgs.) (2007). Metodologia de Pesquisa em Jornalismo. Petrópolis: Vozes.

ВНАВНА, Н. (2006). The location of culture. London: Routledge Classics.

BHАBНA, H. (1990). Nation and Narration. London: Routledge.

BIRD, E. \& DARDENNE, R. (1999). "Mito, registro e estórias: explorando as qualidades narrativas das notícias”. In TRAQUINA, N. (Org.). Jornalismo: questões, teorias e 'estórias'. Lisboa: Vega. 
Certeau, M. (2000). A invenção do cotidiano. Petrópolis: Vozes.

FOUCALT, M. (2002). The Archeology of Knowledge. London: Routledge.

FRANÇA, V.; CORRÊA, L. (Orgs.). Mídia, instituições e valores. Belo Horizonte: Autêntica.

FRANÇA, V. (2006). "Sujeito da comunicação, sujeitos em comunicação». In FRANÇA, V.; GUIMARÃES, C. (Orgs.). Na mídia, na rua: narrativas do cotidiano. Belo Horizonte: Autêntica.

FRANÇA, V. (2004) "Representações, mediações e práticas comunicativas". In FOLLAIN \& GOMES \& PEREIRA (Orgs.). Comunicação, representação e práticas sociais. Rio de Janeiro: PUC-Rio.

GENET, J. (2003). The Prisoner of Love. New York: Review Books.

GOMES, M. (2008). Comunicação e Identificação: ressonâncias no jornalismo. Cotia: Ateliê Editorial.

HEIDEGGER, M. (2003). A caminho da linguagem. Petrópolis: Vozes.

KHALIDI, R. (2010). Palestinian Identity - the construction of modern national consciousness. New York: Columbia University Press.

LATOUR, B. (2009). Jamais fomos modernos - ensaio de antropologia simétrica. São Paulo: Nova Fronteira.

MARCOS, M. (2010). "Comunicação, experiência e a questão do reconhecimento: a alteridade radical no pensamento de Levinas" (entrevista)" in Intercom - Revista Brasileira de Ciências da Comunicação, São Paulo, v. 33, n. 2, pp. 240-251.

MARCOS, M. (2007). Princípio da relação e paradigma comunicacional. Lisboa: Colibri.

MATAR, D. \& HARB, Z. (Eds.) (2013). Narrating conflict in the Middle East: discourse, image and communications practices in Lebanon and Palestine. London: I B Tauris.

MATTOS, O. (2006). Discretas esperanças - reflexões filosóficas sobre o mundo contemporâneo. São Paulo: Nova Alexandria.

PAPPÉ, I. \& HILAL, J. (2010). Across the wall-narratives of Israeli-Palestinian History. London: I.B.Tauris.

RANCIÈRE, J. (2012). O destino das imagens. Rio de Janeiro: Contraponto.

RANCIÈRE, J. (2005). A partilha do sensível: estética e política. São Paulo: Ed. 34.

RASHID, K. (2010). Palestinian Identity - The construction of Modern National Consciousness. New York: Columbia University Press. 
RESENDE, F. (2012). "Falar para as massas, falar com o Outro: valores e desafios do jornalismo", in FRANÇA, V. \& VAZ, P. (Orgs.). Comunicação midiática: instituições, valores, cultura. Belo Horizonte: Autêntica.

RESENDE, F. e PAES, A. $\left(2011^{\mathrm{b}}\right)$. The Arab conflicts and the media discourse - a Brazilian perspective", in Global Media and Communication Journal. London: Sage, vol.7, n.3, pp. 215-219.

RESENDE, F. (2011ª) "Às desordens e aos sentidos: a narrativa como problema de pesquisa", in SILVA, G., KÜNSCH, D., BERGER, C. e ALBUQUERQUE, A. (Orgs.). Jornalismo contemporâneo - figurações, impasses e perspectivas. Salvador: Edufba, pp. 119-138.

RESENDE, F. (2008). “(Des)caminhos: o jornalismo e seus desafios metodológicos”, in Revista Galáxia. São Paulo: PUC-SP, n.15/julho.

RICOEUR, P. (2010). Tempo e narrativa. (Tomos 1, 2 e 3). São Paulo: Martins Fontes.

RICOEUR, P. (2005). "Discours et communicacion", in Cabier de L'Herne Ricouer. Paris: Editions de L'Herne, n.81.

ROGOFF, I. (2000). Terra Infirma: geography's visual culture. London: Routledge

SACCO, J. (2010). Notas Sobre Gaza. São Paulo: Companhia das Letras.

SACCO, J. (2005). Palestina - Na Faixa de Gaza. São Paulo, Conrad.

SACCO, J. (2000). Palestina: Uma Nação Ocupada. São Paulo: Conrad.

SAID, E. (2003). Culture and Resistance: conversations with Ed. Said. Cambridge: South End Press.

SAID, E. (1994). Culture and Imperialism. London: Vintage.

SAID, E. (1992). The Question of Palestine. London: Vintage Books.

SAID, E. (1989). "Representing the Colonized: Anthropology's Interlocutors", in Critical Inquiry, Vol. 15, No. 2.

SAID, E. (1986). After the last sky. New York: Pantheon Books.

SCHUDSON, M. (2001). "The objectivity norm in American newspapers", in Journalism: theory, practice and criticism. Vol.2, N.2, pp. 149-170.

SERRES, M. (2015). Narrativas do Humanismo. Rio de Janeiro: Bertrand Brasil.

TAWIL-SOURI, H. (2012). “The necessary politics of Palestinian Cultural Studies”, in SABRY, T. (Ed.). Arab Cultural Studies - mapping the field. London: I.B.Tauris. TODOROV, T. (2009). A literatura em perigo. São Paulo: Difel. 
TUCHMAN, G. (1999). "Contando estórias", in TRAQUINA, N. (Org.). Jornalismo: questões, teorias e 'estórias'. Lisboa: Vega. 


\title{
ESTUDOS NARRATIVOS E TEORIA DO JORNALISMO: A NARRATIVA DE VEJA E ISTO É SOBRE UMA MANIFESTAÇÃO DE ESTUDANTES DA USP ${ }^{54}$
}

\author{
Bruno Araújo
}

Universidade de Brasília/CEIS 20

\section{Introdução}

A arena mediática se constituiu, ao longo dos tempos, como espaço privilegiado de discussão da atualidade, ao qual recorremos continuamente, para obter informações acerca do que se passa a nossa volta. O campo jornalístico, em particular, erigiu-se em torno de um conjunto de ideias míticas, relacionadas ao poder social do jornalismo, que se autodenomina de contrapoder, cão de guarda, ou, pomposamente, de guardião dos sistemas democráticos, sem admitir, contudo, que integra o sistema político de qualquer democracia e que atua politicamente em muitas ocasiões. Tendo por base essas concepções - que formam aquilo a que Traquina (2007) chama de tribo jornalística - o jornalismo e a sua produção foram vistos, por muito tempo, como verdadeiros espelhos ou representantes fiéis dos acontecimentos.

\footnotetext{
${ }^{54}$ Uma primeira versão deste texto foi publicada na Biblioteca Online de Ciências da Comunicação (BOCC).
} 
Com a chegada das teorias do newsmaking, na segunda metade do século passado, teóricos passaram a entender a práxis jornalística de modo contrário: tratar-se-ia de uma ação comunicativa que constrói e modela a realidade no exato momento em que a reporta. Essa concepção construtivista levou diversos autores ao estudo do substrato narrativo subjacente ao texto e à enunciação jornalísticos, perspectivando notícias, reportagens e outros produtos informativos como narrativas ou estórias. A teoria do jornalismo começava, pois, a relacionar-se com um conjunto de contribuições teóricas provenientes dos estudos literários, numa tendência demonstrativa da profunda abertura epistemológica por que passou a narratologia.

Circunscrita inicialmente ao universo da literatura, a narratologia moderna deve o seu alargamento a outras disciplinas do conhecimento, no final dos anos 1960, aos esforços de homens como Roland Barthes, Claude Bremond, Gérard Genette, A. J. Greimas e muitos outros. No conhecido número oito da revista francesa Communications, esses autores iniciaram uma mudança radical nos pressupostos conceptuais da narrativa, contribuindo para a transformação da narratologia numa área interdisciplinar, transdisciplinar e, por vezes, contradisciplinar. A narrativa deixou de estar associada apenas à linguagem verbal e escrita, passando a ser encarada como fenômeno universal, integrante do processo histórico, suscetível de apresentar-se sob diferentes suportes, em tempos diversos. Com efeito, o conceito foi de tal maneira alargado que se tornou objeto de estudo de inúmeras áreas do saber, todas com inquietações epistemológicas específicas, para cujas respostas as narrativas se transformaram em terreno empírico privilegiado.

Neste artigo, reunindo contribuições dos estudos narrativos e da teoria jornalística, procuraremos refletir, em primeiro lugar, acerca da existência de formas distintas de narrar a realidade no jornalismo, que mudam de acordo com o modo como o enunciador interpreta e estrutura discursivamente os acontecimentos, em consonância com fatores 
intrínsecos e extrínsecos ao trabalho jornalístico. Convocaremos, em primeiro lugar, alguns conceitos dos estudos narrativos - entre eles, o próprio conceito de narrativa - com o objetivo de pensar as narrativas jornalísticas, que possuem um dever de colagem à realidade factual, mas guardam profundas semelhanças narratológicas com outros tipos de narrativa. Tendo isso em vista, trataremos, em segundo lugar, de verificar, na análise de duas reportagens acerca de uma manifestação de estudantes da Universidade de São Paulo, como ocorre esse processo de moldagem da realidade, observando em que medida o dever referencial que caracteriza o jornalismo se mantém ou não intacto.

\section{Influências do modo narrativo sobre o do discurso jornalístico}

Como forma de demonstrar a transversalidade e a complexidade da narrativa, diz-nos Barthes, num dos textos seminais da nova fase dos estudos narrativos:

(...) le récit est présent dans tous les temps, dans tous les lieux, dans toutes les sociétés; le récit commence avec l'histoire même de l'humanité; il n'y a pas, il n'y a jamais eu nulle part aucun peuple sans récit; toutes les classes, tous les groupes humains ont leurs récits (...) le récit se moque de la bonne et de la mauvaise littérature: international, transhistorique, transculturel, le récit est là, comme la vie (Barthes, 1977: 8-9)

Partindo do estímulo barthesiano, para que possamos entender a notícia, a reportagem e outras produções jornalísticas como construções narrativas, precisamos recorrer ao próprio conceito de narrativa, problematizado por um rol de autores. Segundo Gérard Genette "a narrativa é a representação de um acontecimento ou de uma série 
de acontecimentos, reais ou fictícios, por meio da linguagem e, mais particularmente, da linguagem escrita" (Genette apud Silva, 2007: 50). Todorov, por sua vez, acredita que "a narrativa é um texto referencial com temporalidade representada" (Todorov apud Silva, 2007: 50). Ambos os autores elucidam aspectos cruciais para a concepção de qualquer narrativa, incluindo as jornalísticas.

Se os aplicarmos ao gênero reportagem, por exemplo, encontraremos inúmeras semelhanças. A própria etimologia da palavra - reportare, quer dizer: transportar - indica movimento de transporte de uma determinada realidade para o público, o que faz da reportagem um gênero flagrantemente referencial. Da mesma forma, esse tipo textual organiza ações em sucessão e as insere numa linha temporal específica. Naturalmente, nem as ações, nem o fator tempo de uma narrativa jornalística assumem a mesma complexidade que teriam numa narrativa romanesca ou em outra com sofisticação similar.

Seymour Chartman também oferece um conceito de narrativa que, da mesma forma, pode ser aplicado ao texto jornalístico. Para o autor,

\footnotetext{
una narración es un conjunto porque está constituido de elementos - sucesos y existentes - que son individuales y distintos, pero la narración es un compuesto secuencial. Además, los sucesos, en la narración (al contrario de la compilación fortuita), tienden a estar relacionados o ser causa unos de otros (Chartman, 1990: 21).
}

Com efeito, o discurso jornalístico lança mão de um conjunto de procedimentos que deixam antever um acentuado grau de narratividade. Um exemplo é o modo de organização das ações, numa lógica sequencial, ainda que não cronológica haja vista as convenções textuais ditadas pelo lead das notícias, escritas segundo um modelo de pirâmide invertida. A sucessividade das ações nos textos jornalísticos, não sendo resultado de uma compilação fortuita, como 
diz Chartman, faz parte de um universo muito maior de enunciação e produção de sentidos no interior do qual o jornalista exerce papel enunciativo proeminente.

Estudando, pois, o grau de narratividade das narrativas jornalísticas, Fernando Resende chama a atenção para algumas de suas particularidades, quando as confrontamos com outros tipos de narrativa:

\footnotetext{
Nas narrativas jornalísticas, o ato de narrar é uma problemática a ser enfrentada. Nelas, a forma autoritária de narrar as histórias mantém-se, e, de certa forma, com muitos agravantes por apresentar-se velada. Envolto no real e na verdade como referentes, além de trazer a imparcialidade e a objetividade como operadores, o discurso jornalístico tradicional - aquele que é epistemologicamente reconhecido - dispõe de escassos recursos com os quais narrar os fatos do quotidiano (Resende, 2006: 8).
}

A essa dimensão acrescentamos, com Michael Schudson, que, como todas as outras, as narrativas jornalísticas são produtos culturais contemporâneos, pois retêm ecos da realidade onde são construídas. Relativamente às notícias, o autor destaca que "as notícias como uma forma de cultura porque incorporam suposições acerca do que importa, do que faz sentido, em que tempo e em que lugar vivemos, qual a extensão de considerações que devemos considerar" (Schudson apud Traquina, 1999).

\section{Teorias do newsmaking: outro olhar sobre a produção da notícia}

As ideias defendidas pelo newsmaking visam combater pressupostos da teoria do espelho, uma das primeiras teorias do jornalismo, segundo a qual os jornalistas seriam agentes descomprometidos, cuja intenção principal seria transmitir objetivamente a realidade, 
sem interferências no curso normal dos acontecimentos. O combate a essa visão causou grandes discussões entre os profissionais, que preferem apresentar-se como narradores objetivos da realidade, na medida em que isso reafirma a credibilidade com que justificam a sua atuação na esfera pública (Guazina, 2011). Traquina é elucidativo a esse propósito:

\begin{abstract}
O ethos dominante, os valores e as normas identificadas com um papel de árbitro, os procedimentos identificados com o profissionalismo, faz com que dificilmente os membros da comunidade jornalística aceitem qualquer ataque à teoria do espelho, porque a legitimidade e a credibilidade dos jornalistas estão assentes na crença social de que as notícias refletem a realidade (Traquina, 2004: 149).
\end{abstract}

A legitimidade e a credibilidade, sublinhadas pelo autor, são valores profissionais construídos ao longo do processo de profissionalização do jornalismo, com raízes na fase de industrialização da imprensa, no século XIX. A criação e a propagação de uma visão apática e descomprometida do profissional fazia parte de uma estratégia econômica que visava alargar os públicos, atrair mais publicidade para os jornais e, assim, fazer da imprensa um negócio lucrativo. Era, por isso, importante defender a teoria do espelho, como forma de abafar a imagem de uma imprensa panfletária, parcial, que transformava os periódicos em verdadeiras máquinas políticas.

Um dos principais argumentos daqueles que refutam a visão do jornalismo como espelho da realidade é a impossibilidade de existência de uma linguagem neutra ou de um grau zero na escrita. Ao dar vida textual a um acontecimento, o jornalista incorpora, mesmo involuntariamente, marcas da sua subjetividade e das que derivam das relações intersubjetivas estabelecidas com outros atores, dentro e fora da profissão, que impedem um retrato fiel do que se passa no mundo 
ontológico. Diante dessa impossibilidade, também marcada por diversos constrangimentos profissionais - de que a escassez de tempo, a linha editorial do veículo ou a influência das fontes são exemplos clássicos - que organizam as rotinas de produção, a enunciação jornalística é sempre o resultado de um recorte deliberado, de uma construção discursiva do real, necessariamente truncado, na medida em que a sua figuração obedece a códigos de seleção previamente estipulados pelo enunciador com vista à criação de determinados efeitos de sentido.

Por outro lado, alguns autores, como Gaye Tuchman (2002), referem que o texto jornalístico é sempre uma estória. É preciso estar atento, todavia, a possíveis associações errôneas desses termos a uma ficcionalização do real. Encarar as notícias e as reportagens como construções não é o mesmo que as pensar, por exemplo, na perspetiva da criação literária, na qual o autor é livre para percorrer os universos possíveis da imaginação. Por isso, o jornalista-contador-de-estórias analogia comum entre os autores do paradigma construtivista - não é um ficcionista, mas um indivíduo que assume uma postura distinta da do jornalista-espelho, defendida por paradigmas anteriores.

Essa reflexão está bem presente no pensamento de Bird e Dardenne (1999: 163), para os quais "considerar as notícias como narrativas não nega o valor de as considerar como correspondentes da realidade exterior". Gaye Tuchman vai além: "dizer que uma notícia é uma estória não é, de modo algum, rebaixar a notícia, nem acusá-la de ser fictícia. Melhor, alerta-nos para o fato de a notícia, como todos os documentos públicos, ser uma realidade construída possuidora da sua própria validade interna (Tuchman, 1999: 262).

Toda essa discussão é suficiente para compreendermos o enorme poder social dos media sobre a opinião pública. Para além de manterem influência determinante na definição dos temas da agenda pública, eles "interferem no status quo e recriam modos de vida, porque leem e provocam releituras de experiências subjetivas e objetivas e, vale dizer, de forma às vezes tão imperativa, que se tornam 
o lugar de onde as pessoas retiram o que sabem e o que se dispõem a compreender acerca do quotidiano e da vida" (Resende, 2006: 2).

\section{Apontamentos metodológicos}

No sentido de trabalhar empiricamente algumas das questões discutidas anteriormente, com especial interesse na observação do modo como a realidade é retratada pelo jornalismo, selecionamos textos jornalísticos publicados em duas revistas brasileiras de circulação semanal a propósito de uma manifestação de estudantes da Universidade de São Paulo. Trata-se das reportagens "A rebelião dos mimados", publicada por Veja, e "Quem são os radicais da USP", veiculada em IstoÉ. A dimensão limitada do corpus respeita os pressupostos das análises qualitativas, nomeadamente os da análise crítica do discurso. Essa exige do analista a circunscrição máxima do seu objeto de estudo no sentido de esmiuçá-lo ao pormenor, para identificar as estruturas de sentido mais profundas e, por isso, menos visíveis do texto. Também por essa razão, a análise dará ênfase sobretudo aos títulos, subtítulos e lead - fragmentos que constituem, para van Dijk (2005), a superestrutura do texto jornalístico, pois concentram as linhas centrais de conteúdo a partir das quais a macroestrutura textual se configura.

Sendo o jornalismo uma profissão que lida diretamente com a realidade, reconstruindo-a, através de narrativas, recorreremos à Análise Crítica do Discurso, que oferece um rol de ferramentas capazes de demarcar as estratégias textuais e os dispositivos ideológicos das narrativas jornalísticas. Observaremos, portanto, as opções lexicais e as estruturas linguísticas que materializam textualmente as ideias do enunciador narrativo, tendo em especial atenção que as escolhas "feitas pelo produtor textual são simultaneamente escolhas ideacionais e interpessoais, que expressam opções ideológicas particulares" 
(Pedro, 1997: 306). Analisaremos a presença da interdiscursividade nas narrativas, que é uma estratégia discursiva que insere outras estruturas discursivas, textuais e contextuais, no discurso principal, com o objetivo de criar certos efeitos de sentido (Fairclough, 2001). Além disso, a genericização do real, que consiste na redução de eventos e indivíduos a abordagens genéricas - e, por consequência, estereotipadas - integrará o conjunto de categorias desta análise (van Leeuwen, 1997).

Esse conjunto de ferramentas possibilitará observar a maneira como o narrador-jornalista construiu, em cada caso, a narrativa de uma manifestação estudantil, elucidando o conjunto de opções que contribuíram para a construção de determinadas constelações semânticas em torno do evento narrado. Procuraremos, ainda, perceber os procedimentos que incidiram na construção identitária dos estudantes, vistos aqui como personagem jornalística, cuja figuração "(...) é submetida a um trabalho de construção e composição que nos impede de a lermos com o reflexo especular da figura real que the deu origem" (Peixinho, 2014: 332). Naturalmente, o modo de figuração do estudante como personagem terá influência sobre a percepção pública acerca dos movimentos estudantis, encarados como positivos ou negativos em função da semantização operada pelas revistas.

\section{A narrativa de Veja e IstoÉ sobre uma manifestação estudantil}

\section{Veja: "A rebelião dos mimados"}

A reportagem em análise, publicada em nove de novembro de 2011, e assinada por Marcelo Sperandio, assume claros sentidos ideológicos, observáveis tanto pelas escolhas lexicais e linguísticas do narrador-jornalista, quanto pela forma como a narrativa é estruturada pelo enunciador. Também a fotografia aparece aqui como elemento 
semiológico crucial, que auxilia na formação de uma certa unidade semântica da narrativa.

Inicialmente, o título, o subtítulo e o lead cumprem o modelo de superstrutura, aplicado por Teun van Dijk (2005:67) às notícias. Embora a técnica jornalística do lead não seja comummente utilizada em reportagens - produções que primam por uma maior liberdade criativa do jornalista - o primeiro parágrafo responde às cinco perguntas (o quê, quem, quando, onde e porquê), organizadas numa relação de causalidade que confere à produção um certo hibridismo classificatório quanto ao gênero jornalístico em causa.

A utilização da palavra [rebelião], em posição topicalizada - no título - remete-nos para a ideia de que houve uma resistência violenta, protagonizada por indivíduos de atos excessivos [mimados]. O subtítulo possui um sentido global, que poderá ser dividido em três proposições menores, com significados próprios, mas interdependentes: [Com roupas de grife e donos de carros caros] remete o leitor para o estatuto socioeconômico dos estudantes envolvidos; [estudantes depredam a USP] indica um ato de extrema violência, confirmado pelo verbo, na terceira pessoa do plural, do presente do indicativo - "depredam" - de estudantes contra a instituição universitária inteira - "USP", a qual aparece em posição passiva, logo, na condição de quem sofreu uma determinada ação; finalmente, em [porque querem fumar maconha sem ser incomodados], a conjunção de causalidade - "porque" - indica o motivo pelo qual os estudantes "depredaram" a instituição.

Com efeito, todas essas significações limitam horizontes de expectativas e indicam protocolos de leitura, através dos quais o público poderá fazer a sua interpretação, em conformidade ou não com a proposta cognitiva do enunciador. Logo no primeiro parágrafo, o narrador-jornalista chama a atenção do leitor para uma das imagens (fig. 1), que mostra um estudante sorridente - postura que contrasta, desde já, com a situação de revolta enunciada no título - e especifica 


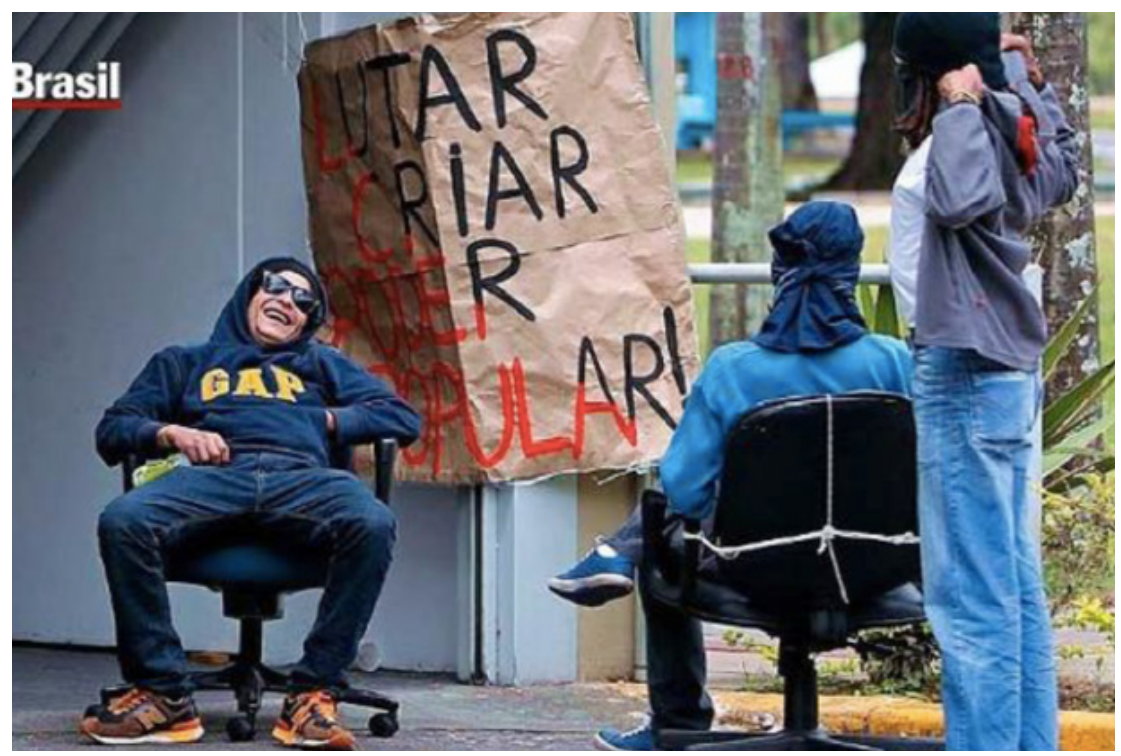

Figura 1: Imagem publicada na reportagem de Veja Fonte: Veja, 9 de nov. 2011

determinados atributos dos envolvidos [moletom da grife americana GAP; óculos de 500 reais da italiana Ray Ban], que, vale dizer, são representados pela figura individual do estudante [o rebelde de GAP], apresentado, genericamente, como o [retrato fiel] do grupo de estudantes. Note-se, aqui, a tentativa de situar esse estudante na condição de personagem-tipo da narrativa, uma subcategoria que se caracteriza pela reunião de um conjunto de traços facilmente identificáveis pelo leitor, comportando, assim, enorme efeito representativo.

Sem nenhuma dúvida, a estratégia de genericização da realidade a que fizemos alusão contribui para a formatação de um perfil específico dos manifestantes perante o público da revista. Tratar-se-ia de indivíduos irresponsáveis, de classe média alta, que querem, impunemente, fazer uso de drogas, no campus universitário. A criação dessa 
imagem dos estudantes - ou, segundo van Leeuwen (1997), desses atores sociais perspectivados como personagens jornalísticas - é feita, paulatinamente, ao longo de toda a narrativa, sempre com recurso a estruturas proposicionais assertivas, que insistem no realce da posição socioeconômica dos estudantes, como em: [circulam em carros cujo preço supera 50.000 reais]; [assumiu a direção de um Polo Sedan e outro embarcou em seu Kia Soul]. O protocolo de leitura oferecido ao leitor também é instituído aí pelo recurso à interdiscursividade cuja presença é comprovada pela alusão a ícones de uma vestimenta luxuosa.

Além disso, o narrador-jornalista seleciona um conjunto de sinônimos para o termo "estudantes", através de um processo continuado de categorização, que possui uma carga semântica altamente disfórica. Os manifestantes são tratados, várias vezes, como: "maconheiros"; "mimados"; "rebeldes"; "crianças"; "garoto mimado"; "birrentos"; "vândalos"; "filhinhos de papai"; "invasores"; "rebeldes mimados"; "mauricinhos”. Por outro lado, a manifestação, propriamente dita, é referida como: "bagunça"; "pirraça"; "rastro de destruição"; "baderna"; "arruaça"; "turba”. Ora, a utilização desse vocabulário é resultado não apenas de escolhas lexicais determinadas, mas, como lembra van Dijk (2005), são, claramente, decisões ideológicas, que revelam o posicionamento do enunciador e, consequentemente, constroem mapas mentais de percepção, importantes para que também o público se posicione.

Mesmo assim, o narrador-jornalista encontra outras formas, - muito mais visíveis - de se posicionar. Ao longo da narrativa, as proposições, em posição subordinada: [mas, coitadinhos, a lei não deixa] e [revolução tem limite], bem como, a proposição que finaliza o texto, após uma citação em discurso direto, [Esse menino precisa de castigo, papai], representam, visivelmente, a voz do narrador, que não se exime de assumir um discurso avaliativo em relação à situação narrada, numa atitude que não encontra guarida na vasta literatura sobre boas práticas jornalísticas. Trata-se, aqui, claramente, de uma narrativa em estilo panfletário, visto que todas as estratégias discursivas mobilizadas pelo 
enunciador possuem o condão de construir um argumento depreciativo em face da manifestação, sem a menor preocupação em ouvir diretamente os envolvidos na ação. A narrativa parte de uma premissa - os estudantes são mimados - e converge um conjunto de estratégias ao longo do seu desenvolvimento para demonstrar isso mesmo.

Por fim, é importante salientar a citação mimética, em discurso direto, da mãe de um estudante da USP, - assassinado, há meses, após uma tentativa de assalto -, que vê a manifestação como um [capricho de uma minoria]. O pensamento da mãe, emocionalmente fragilizada, é outra estratégia discursiva fundamental para a confirmação de todo o processo de significação disfórica, gradativamente, criado no decorrer da narrativa. Essa estratégia, com efeito, possui o objetivo de acrescentar à diegese uma digressão em nada relacionada com o foco da manifestação ali retratada.

\section{IstoÉ: "Quem são os radicais da USP"}

Publicada em onze de novembro de 2011 e assinada por Alan Rodrigues, a reportagem da revista IstoÉ apresenta diversos pontos de contraste e relação à postura de Veja, analisada anteriormente. Ao longo da nossa análise, observamos um tom mais sóbrio do enunciador na abordagem das questões, e uma tendência para dar voz aos estudantes, enquanto atores sociais diretamente envolvidos na situação. Essa postura, todavia, não significa a inexistência de dispositivos ideológicos que estruturam a narrativa na medida em que instituem determinados significados tanto em relação aos manifestantes quanto acerca do próprio evento.

Primeiramente, o título, o subtítulo e o primeiro parágrafo (que, neste caso, por tratar-se de uma reportagem, não se assume como lead convencional) cumprem o esquema superstrutural, defendido por van Dijk (2005: 67), visto que que funcionam como elementos 
de fundamental importância para a definição da macroestrutura semântica do texto. Todavia, o fato de não ser feita nenhuma referência direta à manifestação propriamente dita, no título, revela que o narrador-jornalista partiu do pressuposto de que o público estaria já suficientemente familiarizado com os acontecimentos. Parece que o objetivo do enunciador textual é a definição de um perfil dos manifestantes, que começa a ser feito logo no título, com o recurso ao pronome de interrogação [quem], ligado pelo verbo ser na terceira pessoa do presente do indicativo [são] ao nome [radicais], que, por sua vez, caracteriza indivíduos insatisfeitos com determinadas normas ou padrões estabelecidos. De início, o enunciador trata os manifestantes como "radicais", atribuindo-lhes desde já uma adjetivação negativa.

No subtítulo, encontramos uma nítida diferença em relação à produção anterior: a construção proposicional [Eles têm pouco em comum] indica a existência de diferenças entre os manifestantes, sobretudo ao nível socioeconômico, confirmadas pela proposição subsequente [Alguns vieram da escola pública e outros estudaram no Exterior]. Obviamente, por meio de um processo de pressuposição, os termos [escola pública] e [Exterior] são utilizados como elementos indicadores de patamares sociais diferenciados, bem diferente da estratégia anterior de redução dos manifestantes a traços identificadores comuns e genéricos. Mesmo sem dizê-lo, o narrador sabe que a sua mensagem chegará ao leitor, porque entende que esses termos fazem parte "de um conjunto de conhecimentos culturais tácitos que dão significado ao discurso". (Van Dijk, 2005: 171).

O primeiro parágrafo é também bastante esclarecedor. Assim como na reportagem anterior, o enunciador inicia o texto centrado na figura de um estudante, - que, neste caso, tem nome e idade: [João Machado, 20 anos]. As citações miméticas, em discurso direto [Minha mãe quer me matar] e [Ela só sabe xingar] revelam que há uma discordância dos pais relativamente à atitude dos filhos. No entanto, a postura dos estudantes é inserida no universo do movimento estudantil enquanto 
fenômeno político cujo objetivo é a reivindicação de um conjunto de questões e a luta contra um poder repressor. Tal ideia é confirmada pela utilização de termos como: [momento histórico], em discurso direto, ou [tomada do poder].

Um fator interessante a destacar é a referência ao ato dos estudantes como [ocupação] da reitoria, diferentemente de [invasão], utilizada uma única vez, no segundo parágrafo [invadiram]. Por sua vez, os agentes sociais são categorizados como: "estudantes"; "adolescentes"; "radicais sem rosto"; "jovens". Sem dúvidas, os sentidos em torno dessas opções lexicais contribuem para a criação de uma identidade social dos estudantes distinta da que vimos no texto anterior.

Mais uma vez, as diferenças socioeconômicas entre os manifestantes são elucidadas ao longo da narrativa. Elencamos, ao menos, três exemplos: no terceiro parágrafo, a enumeração de profissões [auxiliar de escritório, artesão, analista de laboratório, professores, iluminador e até barman] comprova isso. Posteriormente, o fato de os estudantes não terem dinheiro para pagar a fiança à polícia [Boa parte deles não tinha os $\mathrm{R} \$ 545$ da fiança]. E, ainda, no quinto parágrafo, a condição humilde de Rafael Alves, apresentado como [um dos principais líderes dos radicais], confirmada pela estrutura proposicional [De origem humilde, egresso da escola pública, foi o único dos 20 integrantes da sua família que conseguiu entrar na universidade]. Evidentemente, são feitas referências a estudantes de classe média - como, no caso do primeiro estudante, apresentado como sendo [de classe média paulista]. No entanto, essas diferenças não existem no trabalho de Veja, que apresenta as personagens como provenientes de classes sociais economicamente superiores.

É importante chamar a atenção para as imagens que integram o texto, contribuindo para a construção de efeitos de sentido na narrativa. Uma das fotografias, em particular, tem especial ligação com a ideia de movimento estudantil, entendido como manifesto político-social. Por meio de uma estratégia interdiscursiva, essa ideia é simbolicamente 


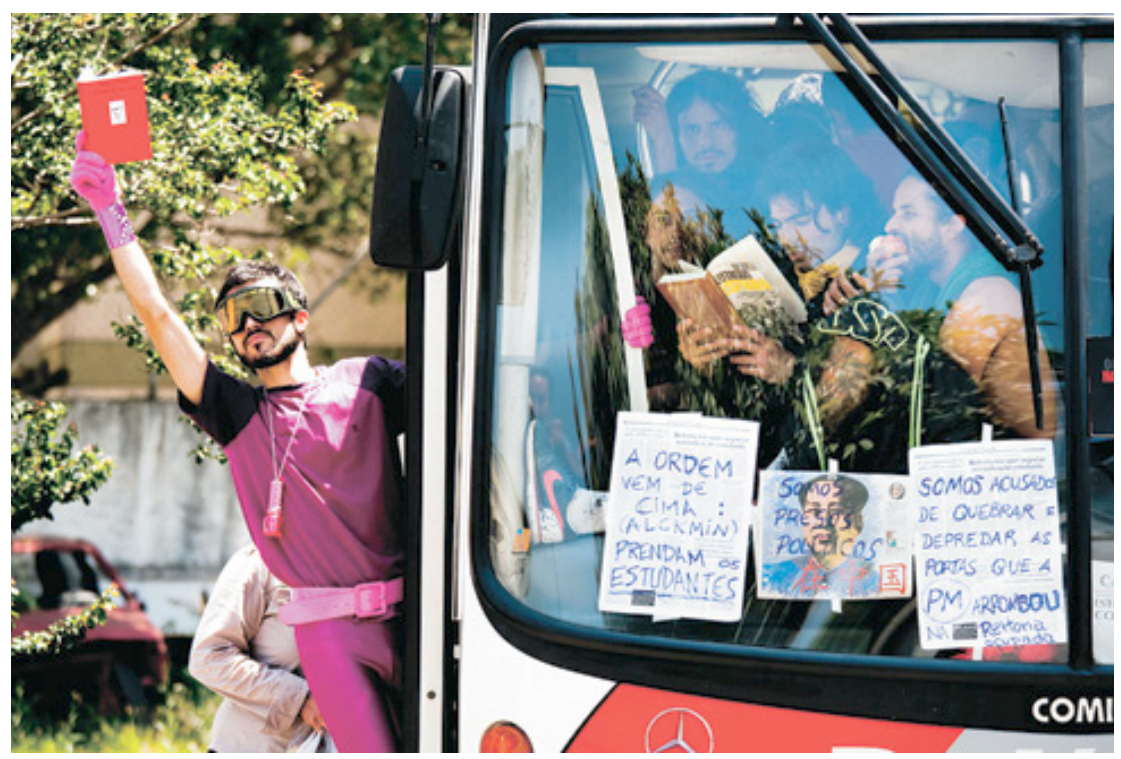

Figura 2: Fotografia na reportagem de $I s t o E$

Fonte: IstoÉ, 11 de nov. 2011

representada quando um estudante aparece erguendo a obra do filósofo Michel Foucault, conhecido por denunciar as injustiças sociais derivadas das relações de opressão que marcam a evolução das sociedades ocidentais, manifestadas nas desigualdades políticas, sexuais e de gênero que os diferentes discursos manifestam (fig. 2).

Por fim, é forçoso referir outro ponto, que mostra bem as diferenças semânticas e ideológicas de ambas as narrativas: IstoÉ não faz alusão aos estudantes como consumidores de drogas, contrariamente ao que faz o narrador-jornalística em Veja. Pelo contrário, dá-se ênfase à manifestação, como parte integrante do movimento estudantil, que possui reivindicações variadas, em detrimento do fato pontual de alguns estudantes, que também se manifestam, quererem "fumar maconha sem ser incomodados", como enfatizou, em diversas ocasiões, a narrativa anterior. 


\section{Considerações finais}

O presente artigo procurou aliar alguns dos pressupostos conceptuais mais importantes dos estudos narrativos e da investigação em jornalismo, para ampliar o debate, já existente, em torno da práxis jornalística como produtora de significações que moldam e constituem a realidade publicada. Num primeiro momento, buscamos problematizar o conceito de narrativa, para entender o que são e como funcionam as narrativas jornalísticas que, não obstante comunguem de características presentes em outras narrativas, devem necessariamente obedecer a um protocolo comunicacional de máxima referencialidade com o real (Calatrava, 2008).

Com recurso ao pensamento de autores como Tuchman (2002) e Traquina (2007), resgatamos perspectivas que refutam a ideia de que o jornalismo espelha ou representa a realidade. O discurso jornalístico, ao contrário, reúne uma série de dispositivos textuais e ideológicos que impedem a reconstituição exata da realidade ontológica no texto: ao retratá-la, a enunciação jornalística oferece ao leitor propostas de cognição dos eventos sociais que funcionam como molduras ou, como diria Bourdieu (2001), como óculos a partir dos quais esses eventos são lidos. Grosso modo, a realidade jornalisticamente retratada não passa de uma construção do mundo empírico, sem que isso implique necessariamente a veiculação de falsas informações ou a criação de narrativas ficcionais puras - o que conduziria a uma subversão dos princípios deontológicos mais básicos do jornalismo.

A análise das narrativas de Veja e IstoÉ a respeito de um único evento - uma manifestação de estudantes da Universidade de São Paulo - evidenciou vários aspectos elucidativos da discussão teórica anterior, chegando, todavia, a revelar que aquelas narrativas jornalísticas, ao mesmo tempo em que recorreram às convenções linguísticas formais que caracterizam o texto jornalístico, transitaram 
metalepticamente entre os universos da factualidade e da ficção (Genette, 2004) 55 .

Segundo a análise, a revista Veja prezou por uma abordagem extremamente acesa e partidária do acontecimento, assumindo posição contrária à manifestação dos estudantes. Essas personagens figuraram, na narrativa, como adolescentes mimados, consumidores de drogas e provenientes de classes sociais abastadas. Contrariamente, a revista IstoÉ apresentou uma narrativa de tom mais sóbrio, na qual não é feita nenhuma referência ao consumo de drogas pelos estudantes. Além disso, evidenciou diferenças entre as personagens tanto ao nível socioeconômico quanto em relação aos motivos que os teriam levado a estar naquela manifestação, afastando-se, pois, da concepção simplista com que o enunciador de Veja os tratou. Para esse último, a manifestação havia sido um ato vazio, protagonizado por quem não possuía nenhuma demanda razoável, a não ser o objetivo de chamar a atenção, em virtude da condição de garotos mimados.

Naturalmente, a pluralidade de perspectivas no espaço público é sempre uma mais-valia para qualquer sociedade democrática que aspira a uma opinião pública esclarecida. Nesse ponto, os media cumprem um papel de absoluta relevância, já assinalado pela própria teoria democrática. No entanto, o que a análise aqui realizada revela é algo distinto: ao lançarem mão, sobretudo no caso de Veja, de um processo de adjetivação depreciativa de um evento e de seus participantes, as narrativas, de fato, se equivocam no trabalho de informar o público, apostando numa abordagem que vai na contramão da noção de esclarecimento público.

Em suma, o que se observou, na análise, foi a tentativa velada de criminalização de um movimento - na esteira, aliás, da atual tendência global de criminalização do protesto social, como diagnostica

\footnotetext{
${ }^{55}$ Para uma discussão sobre ficcionalidade e factualidade nos processos comunicacionais, vide Babo (1996).
} 
Boaventura de Sousa Santos -, conseguida por meio do realce a características de alguns de seus agentes, os quais, não sendo a maioria, figuraram, na narrativa, como se o fossem. Eis, portanto, um exemplo claro de como a narrativa jornalística - que, sem subterfúgios, deve colar-se ao real, cumprindo, assim, o seu dever de máxima referencialidade (Calatrava, 2008) - pode abrir mão da estrutura comunicacional que permite diferenciá-la dos textos ficcionais, para passear, como diria Umberto Eco (1994), pelos bosques imaginativos da ficção.

\section{REFERÊNCIAS BIBLIOGRÁFICAS}

BARTES, R. (1977). "Analyse Structurale du récit " in Poétique du récit. Paris: Seuils (Points)

BIRD, E. S.; DARDENNE, R. W. (1993), “Mito, registo e 'estórias': explorando as qualidades narrativas das notícias". In TRAQUINA, N. (org.), Jornalismo: Questões, teorias e "estórias". Lisboa: Vega, pp. 263-277.

BOURDIEU, P. (2001). Sobre a televisão. Oeiras: Celta.

CHARTMAN, S. (1990). Historia y discurso: la estrutura narrativa en la novela e en el cine, Madri: Taurus Humanidades.

DIJK, T. V. (2005). Discurso, notícia e ideologia. Estudos da Análise Crítica do Discurso, Porto: Campo das Letras.

ECO, U. (1994). Seis passeios pelos bosques da ficção. São Paulo: Companhia das Letras. FAIRCLOUGH, N. (2001). Discurso e mudança social. Brasília: Editora da UnB.

GENeTte, G. (2004). Métalepse. Paris: Editions du Seuil.

HAMON, P. (1977). "Pour un statut sémiologique du personnage". In BARTHES, R. et aliii, Poétique du récit. Paris: Seuils (Points), pp. 115-167.

MESQUITA, M. (2003). "A personagem jornalística - da Narratologia à Deontologia" in O Quarto Equívoco - O poder dos media na sociedade contemporânea, Coimbra: Minerva.

PEDRO, E. R. (1997). Análise Crítica do Discurso. Lisboa: Caminho. 
PEIXINHO, A. T. (2014). "Procedimentos retórico-narrativos de construção de personagens jornalísticas: o caso do Jornal Expresso durante o verão de 2013", Revista de Estudos Literários, n. 4, Coordenação: Carlos Reis. Coimbra: Centro de Literatura Portuguesa da Universidade de Coimbra.

PENA, F. (2005). Teorias do Jornalismo, São Paulo: Contexto.

REIS, C.; LOPES, A. C. M. (2007). Dicionário de Narratologia, $7^{\mathrm{a}}$ ed., Coimbra: Almedina.

RESENDE, F. (2006). "Jornalismo e enunciação: perspectivas para um narrador jornalista”. In LEMOS, A.; BERGER, C.; BARBOSA, M. (orgs.) Narrativas midiáticas contemporâneas. Porto Alegre: Sulina.

SILVA, M. (2007). "A notícia como narrativa e discurso", Estudos em Jornalismo e Mídia, v.4, no. 1. Universidade Federal de Santa Catarina: Florianópolis.

TRAQUINA, N. (1999). Jornalismo: Questões, Teorias e "estórias", 2ª ed, Lisboa: Vega.

TRAQUINA, N. (2004). Teorias do jornalismo, Florianópolis: Editora Insular.

TRAQUINA, N. (2007). Jornalismo, $2^{\text {a }}$ ed., Lisboa: Quimera.

TRAQUINA, N.(2001). O estudo do jornalismo no século $X X$, São Leopoldo: Unisinos.

TUCHMAN, G. (1993). "Contando estórias" in Nelson Traquina (org.) Jornalismo: Questões, Teorias e "estórias", Lisboa: Vega, pp. 258-262.

TUCHMAN, G. (2002). "As notícias como uma realidade construída". In ESTEVES, J. P. (ed.) Comunicação e Sociedade, Lisboa: Horizonte, pp. 91-104.

VALLES CALATRAVA, J. (2008). Teoría de la narrativa. Una perspectiva sistemática. Madrid: Iberoamericana.

VAN LEEUWEN, T. A. (1997), "A representação dos actores sociais". In PEDRO, E. R. (org.), Análise crítica do discurso. Lisboa: Caminho, pp. 169-222. 


\title{
JORNALISMO, NARRATIVAS E ESCÂNDALOS
}

\author{
Hélder Prior
}

LabCom.IFP/UBI

Universidade de Brasília

\section{A actualidade do escândalo político}

Talvez não seja de todo despropositado iniciar esta reflexão intitulada Jornalismo, Narrativas e Escândalos, referindo que a vida pública das últimas décadas parece, definitivamente, marcada por uma sucessão de escândalos político-mediáticos. Podemos, com efeito, falar de uma cultura do escândalo político, ou de uma política do escândalo, na esfera pública contemporânea. Nesta era de grande visibilidade pública, o escândalo converteu-se numa característica incontornável da vida social e política de muitas democracias liberais, de tal forma que, devido à proliferação de denúncias que redundam em escândalos, parece que já não nos escandalizamos com quase nada. Etimologicamente, presume-se que o termo derive da raiz skand, que significa "surgir" ou "saltar", e apesar da palavra se ter tornado mais usual nos idiomas europeus a partir do século XVI, o vocábulo remonta ao período greco-latino. De facto, a palavra escândalo foi utilizada no Antigo Testamento Hebraico em sentido figurado para designar um "obstáculo", uma "armadilha", ou uma "ocasião de tropeço", de "queda 
no erro". No sentido teológico que encontramos quer no Antigo quer no Novo Testamento, escândalo significa "pedra de tropeço", "coisa que faz cair no mal" ou "ocasião de queda para os fracos". A teologia cristã colocou a ênfase do vocábulo na fragilidade dos indivíduos, daí as expressões "ocasião ou momento de queda", "obstáculo no caminho que leva uma pessoa à queda", "pedra de tropeço", "fazer cair em pecado" ou "dar motivo de censura" 56 .

Em inglês, a palavra scandal surgiu originariamente no século XVI e calcula-se que as palavras latinas escândalo, em português, escándalo, em castelhano, e scandalo, em italiano, tenham surgido aproximadamente na mesma época (Thompson, 2001: 30). Apesar do sentido herdado das Escrituras Sagradas, o termo acabou por adquirir uma significação mais sociológica do que propriamente teológica. Assim, e do ponto de vista sociológico, o escândalo pode ser interpretado como um "assassinato espiritual", como uma provocação aos valores que a sociedade partilha, derrogação dos valores reconhecidos e comungados pelos indivíduos dentro de um contexto societal específico. Não obstante o sentido religioso se ter mantido como um "momento de fraqueza" ou de "queda no erro", a conotação sociológica tornou-se mais comum. Deste modo, sociologicamente o escândalo implica a existência de valores partilhados por um determinado grupo social, a violação ou transgressão desses valores e, claro está, a existência de um público que reconhece essa violação e que se sente ofendido por ela, que se sente "escandalizado". O mesmo é dizer que não há escândalo sem a transgressão de certos valores, estereótipos morais, símbolos ou modelos sociais e, por outro lado, sem a propagação da transgressão e sem a existência de um público que se sente ofendido pelo comportamento escandaloso e que, por isso mesmo, o propaga, o publicita no espaço público.

$\overline{56}$ Conforme São Lucas, 7, 23; Isaías, 8, 15, Carta aos Romanos, 14,13. 
Na obra Political Scandal: power and visibility in the media age, John Thompson sublinha que o "escândalo implica certas formas de transgressão que são conhecidas por terceiros, formas de transgressão suficientemente graves ou sérias para provocar uma resposta pública de reprovação ou indignação" (2001: 32). Segundo o autor, normalmente os escândalos têm quatro características essenciais: 1) a sua existência implica a transgressão de certos valores, normas ou códigos morais; 2) a sua existência implica um elemento de segredo ou de ocultação, elemento que é desvelado e que chega ao conhecimento de indivíduos que não estão directamente implicados nas transgressões; 3) esses indivíduos reprovam essas ações e expressam publicamente os seus sentimentos de reprovação face a essas transgressões, tornando públicos os acontecimentos; 4) a revelação dessas ações ou acontecimentos pode afetar a reputação dos indivíduos responsáveis pelas transgressões entretanto publicitadas.

Apesar do escândalo não ser um fenómeno propriamente novo, o seu alcance, impacto e consequências transformou-se com o desenvolvimento das formas de comunicação mediática. O desenvolvimento dos meios de comunicação criou novas formas de publicidade distintas da publicidade em co-presença ou interação face a face, algo que, como sabemos, teve consequências na visibilidade pública dos dirigentes políticos, possibilitando que as suas mensagens pudessem chegar a uma multiplicidade de receptores que não partilham o mesmo espaço físico, mas que, por outro lado, também gerou novos riscos na gestão das fronteiras tradicionais que separavam os limites entre a esfera pública e a esfera privada.

Por outro lado, os escândalos, tal como se constituem na atualidade enquanto escândalos mediáticos, isto é, enquanto acontecimentos que são selecionados, enquadrados, divulgados e, porque não dizê-lo, moldados pela "máquina narrativa" dos meios de comunicação, devem-se a um conjunto de transformações políticas, sociais e económicas que ocorreram em finais do século XVIII e inícios 
do século XIX, transformações que contribuíram para converter a prática jornalística num campo de ação relativamente autónomo e independente face ao poder político, com uma ética profissional e códigos deontológicos específicos e, por outro lado, que incorporaram os princípios da visibilidade e da transparência na política face ao obscurantismo e face à prática dos arcana imperii ou segredos do poder que vigorou durante séculos. Talvez por isso, alguns jornais do século XVIII, como o Daily Courant, o Daily Post, ou o Daily Journal, já publicavam frequentemente alegações escandalosas sobre a atuação dos ministros do governo britânico. Mais tarde, após a fundação por Pulitzer do New York World e do New York Journal, os novos jornais, de cariz mais ligeiro, passaram a dedicar mais espaço a estórias sensacionais, a acontecimentos insólitos, ao desporto e a aspectos relacionados com a vida privada e com as aventuras pessoais dos dirigentes políticos. Foi o chamado surgimento da penny press e do yellow journalism, uma imprensa que percebeu, desde logo, que a extemporaneidade e espectacularidade inerentes aos escândalos facilmente promovem a adesão de públicos e a captura da atenção pública. É por isso que os escândalos facilmente preenchem os requisitos da lógica da chamada cultura mediática.

Não por acaso, Theodore Lowi considera que na esfera pública hodierna os escândalos políticos adquiriram um importante "valor de uso" na luta pelo "poder simbólico". Nas palavras do autor, o escândalo também é uma commodity que os meios de comunicação e os partidos políticos não podem deixar de explorar. Lowi fala de um certo "mercado do escândalo" (Lowi, 2004: 71) que parece caracterizar a política hodierna, uma mercado explorado quer pelos partidos políticos na luta pela conquista de credibilidade e assentimento, quer pelos meios de comunicação na disputa pela atenção pública. De outro modo, o jornalismo de investigação configura-se, desde o século XIX, como um tipo de jornalismo que atua por debaixo da superfície política, procurando desvelar o "poder invisível", na terminologia de 
Norberto Bobbio (2003), e contribuir para a visibilidade e transparência do poder político, assumindo uma postura vigilante que ficou conhecida por watchdog role of the press.

Porém, apesar da proliferação de escândalos políticos, não é possível dizer que este seja um fenómeno que se possa definir a priori. Se, em alguns casos, os escândalos políticos podem revelar casos de intransparência do poder público, publicitando situações de corrupção e desvios no exercício do poder político, em outros casos aquilo que sobressai é o papel dos meios de comunicação na revelação, publicitação e configuração de um acontecimento que, muitas vezes, se desenvolve como uma narrativa mediática que alimenta o imaginário do leitor ou espectador de produtos informativos. Ora, segundo Markovits e Silverstein, dois dos principais teóricos que trabalharam o fenómeno, o escândalo político poder-se-á definir como a violação dos procedimentos normativos que regulam o exercício do poder, resultando de uma clara tensão entre a lógica do poder, tendencialmente privada e secreta, e a lógica dos procedimentos normativos democráticos de natureza pública, no sentido de visível, de acessível, de algo que pode ser visto por todos (Markovits; Silverstein, 1988: 7). Na perspetiva dos autores, um escândalo político implica necessariamente a "violação do procedimento devido", isto é, a violação das normas e das convenções que regulam o exercício do poder. Neste sentido, os autores concluem que os sistemas políticos que favorecem a proliferação de escândalos políticos na sua essência são as democracias liberais, precisamente pelo facto de as democracias liberais se pautarem por normas e procedimentos normativos que têm uma sólida base institucional. "Se os escândalos políticos não existissem, as democracias liberais tê-los-iam inventado", concluem (1998: 9).

No seguimento das considerações de Markovits e Silverstein, John Thompson apelida este tipo de escândalos de "escândalos de poder", uma distinção terminológica que permite distinguir as transgressões dos procedimentos normativos que regulam o 
exercício do poder como uma forma peculiar de escândalo político. As outras formas ou tipos de escândalo político seriam os escândalos sexuais e os escândalos financeiros que envolvem ou afetam a reputação de dirigentes políticos. Tal como contundentemente assevera o sociólogo:

\begin{abstract}
Podemos distinguir três tipos fundamentais de escândalo na esfera política: aqueles que implicam a transgressão dos códigos sexuais (escândalos sexuais), aqueles que implicam uma má utilização dos recursos económicos (escândalos financeiros), e aqueles que implicam determinados abusos no exercício do poder político (escândalos de poder) (Thompson, 2001:168).
\end{abstract}

Não obstante, o próprio Thompson adverte que a eclosão de escândalos depende, em grande medida, do contexto cultural onde ocorrem as alegadas transgressões e da "força vinculativa" de determinadas normas sociais, força vinculativa que, naturalmente, varia de sociedade para sociedade. Uma vez que qualquer escândalo implica a existência de transgressões, deve referir-se que a variabilidade e diversidade cultural faz com que uma atividade possa resultar num escândalo num determinado contexto cultural e, num outro contexto, seja entendida como algo perfeitamente normal ou aceitável.

Por outro lado, a emergência ou eclosão de um escândalo na modernidade depende do grau de conhecimento público sobre as alegadas transgressões e, também, do grau de reprovação que essas transgressões geram na opinião pública. Neste ponto, o papel da comunicação mediática acaba por ser crucial no processo de publicitação e mediatização dos acontecimentos que estão, ou estiveram, na eclosão de um determinado escândalo. E, quando os desvios do poder político, quando as transgressões cometidas em segredo são denunciadas, enquadradas e divulgadas pelos meios de comunicação, 
gerando sentimentos generalizados de reprovação, o escândalo constitui-se enquanto acontecimento mediático.

O escândalo político confunde-se ou associa-se, muitas vezes, com práticas de corrupção no interior da vida pública. Porém, é importante fazer a distinção conceptual entre os dois termos. Segundo se pode ler no Dicionário da Língua Portuguesa Contemporânea, corrupção significa "decomposição", "putrefacção" ou "deterioração" dos valores morais ${ }^{57}$. Quando deslocado para a linguagem política, $\mathrm{o}$ ato de corrumpere refere a perversão do exercício do poder ou o seu mau uso nas tarefas públicas. Com efeito, para a corrupção se converta em escândalo é indispensável que a transgressão se transforme num elemento visível, se ofereça aos olhos do público. O escândalo apenas se constitui a partir do momento em que se forma um discurso acusatório sobre supostas atividades que causam sentimentos generalizados de desaprovação e repulsa. Por conseguinte, para que a corrupção se converta num escândalo é fundamental que os atos corruptos se revelem e despertem sentimentos de reprovação generalizada. Se a corrupção permanecer latente, ou, ainda que revelada, se não despertar sentimentos de indignação, o escândalo não poderá eclodir.

Ora, de acordo com a perspetiva que pretendemos erigir neste ensaio, a reconfiguração do escândalo político na esfera pública não é um processo aleatório, até porque o acontecimento sofre a ação do medium, isto é, desenvolve-se literalmente nos meios de comunicação e é moldado por eles. Do ponto de vista linguístico, é um processo fáctico, pois deve obedecer ao contrato cognitivo de veracidade face aos factos narrados, provocando os chamados "efeitos de real", mas também é um processo fictício, pois sabemos que os jornalistas exploram efeitos emocionais e expressivos para captar e manter a atenção do leitor,

\footnotetext{
${ }^{57}$ Cf. Dicionário da Língua Portuguesa Contemporânea, Primeiro Volume, Lisboa: Fundação Calouste Gulbenkian: Verbo, 2001, p. 994.
} 
combinando a objetividade com a subjetividade. No caso do escândalo, não devemos esquecer que este provoca, também, os chamados "efeitos de surpresa”, pois o escândalo político é um acontecimento que irrompe na esfera pública, que desequilibra o sistema político e social, escandalizando o público, mas que também desequilibra o próprio sistema dos media, uma vez que altera subitamente a agenda mediática e as próprias rotinas jornalísticas. Por conseguinte, as atividades específicas do campo dos media desempenham um papel determinante na publicitação, agendamento e configuração de um acontecimento que, na maioria das vezes, se constituiu como uma complexa narrativa mediática. Normalmente, os escândalos mediáticos têm uma estrutura temporal e sequencial que é marcada, decisivamente, pelo ritmo próprio dos meios de comunicação, pelas suas pautas de publicação e difusão, mas também pelo papel desempenhado por outras instituições, como as instituições políticas ou judiciais. Apesar dos escândalos mediáticos serem acontecimentos "abertos" ou imprevisíveis, é possível identificar quatro fases no que ao seu desenvolvimento sequencial diz respeito. A primeira é, obviamente, a fase prévia ao escândalo mediático, isto é, as transgressões ou os desvios que estão na base do fenómeno e que, quando reveladas, provocam a sua eclosão. Aqui, podemos incluir as atividades de investigação de jornalistas ou de organizações judiciais, atividades muitas vezes de rotina, mas que acabam por desvelar a quebra de normas ou de códigos sociais, jurídicos ou políticos.

A segunda é a fase da eclosão do escândalo propriamente dito e implica a denúncia pública de uma suposta transgressão. Refere-se à fase da mediatização do acontecimento em que os media acabam por concentrar a atenção pública no caso e mantê-lo na agenda público-mediática durante dias, semanas, meses ou até anos, como acontece no caso de escândalos juridicamente complexos que podem voltar à agenda mediática após um período de menor cobertura informativa. A terceira fase do escândalo mediático refere-se à sua culminação ou desenlace. Neste ponto, os protagonistas envolvidos podem assumir 
a sua culpabilidade no caso, podem assumir as transgressões, a exemplo do que fez Bill Clinton no escândalo sexual que envolveu a sua secretária na Casa Branca, ou, no caso da sua culpabilidade não ficar provada, os indivíduos implicados podem encetar uma batalha judicial contra alguns órgãos de comunicação social por eventuais danos no seu capital político ou na sua reputação. A quarta e última fase, na perspetiva de Thompson (2001: 107-112), diz respeito às consequências do escândalo. Aqui, os meios de comunicação e as próprias instituições políticas podem iniciar uma reflexão sobre os acontecimentos e sobre as suas implicações, discutindo reformas políticas que evitem as transgressões que estiveram na origem do fenómeno, e analisando o acontecimento mediante vários ângulos e várias interpretações, discutindo todos os detalhes da "estória".

\section{Escândalo mediático e Narratividade}

Os escândalos mediáticos são, normalmente, experiências complexas que vão sendo alimentadas pela máquina narrativa dos meios de comunicação. Após as denúncias públicas de que ocorreu algum tipo de transgressão que envolve uma qualquer figura pública, erige-se um certo discurso acusatório acerca das hipotéticas transgressões que, por outro lado, tendem a ser desmentidas pelos indivíduos que se encontram no epicentro do escândalo. De outro modo, em muitos casos as investigações policiais, jornalísticas ou jurídicas sobre as transgressões que estão na origem de um escândalo particular, desvelam novos tipos de transgressões, que Thompson apelida de "transgressões de segunda ordem", que não raras vezes têm uma relação tangencial com os acontecimentos que estiveram na base do fenómeno. Nestes casos, a complexidade, a cobertura mediática e o impacto social do escândalo aumentam consideravelmente e o acontecimento converte-se numa "narrativa com tramas e sub-tramas" 
(Thompson, 2001: 46) que se pode desdobrar em sub-escândalos ou, inclusivamente, em escândalos de maior envergadura que eclipsam, pelo menos do ponto de vista mediático, as chamadas "transgressões de primeira ordem". De certa forma, podemos asseverar que o escândalo apresenta uma dinâmica comunicativa que acaba por favorecer a mediatização e a dramatização do acontecimento. A atenção mediática sobre uma transgressão inicial pode conduzir o debate público para uma dialética de acusação versus defesa. De um lado, os meios de comunicação ou os indivíduos que se encontram implicados na denúncia de hipotéticas transgressões pugnam por uma certa culpabilização e moralização da vida pública; de outro lado, os indivíduos envolvidos no epicentro do escândalo procuram desmentir as acusações de que são alvo, acusando os jornalistas ou os opositores de perseguição, difamação ou aproveitamento político. No caso dos escândalos mais complexos, é previsível que das investigações iniciais surjam novos indícios ou novas revelações que acabam por adensar o debate público sobre o fenómeno, envolver novas transgressões e novas personagens, novas alegações públicas e desmentidos e, consequentemente, novos dados e revelações que acabam por aumentar a complexidade narrativa do próprio escândalo, o quadro enunciativo do acontecimento e a constituição de sentidos.

Como se sabe, os dispositivos mediáticos conferem marcas enunciativas aos acontecimentos e a configuração do escândalo nos media não escapa à lógica de refiguração inerente aos dispositivos de mediação simbólica. O escândalo desenvolve-se, literalmente, nos meios de comunicação mediante um processo de "tessitura da intriga", isto é, mediante a sucessão e o enquadramento dos eventos e das ações no tempo, transformando o acontecimento numa "estória" inteligível, numa "estória" que pode ser facilmente compreendida e apreendida pelo público. O sujeito narrador organiza os factos e os acontecimentos com o objetivo de construir uma totalidade inteligível e de, consequentemente, criar sentido. Compete ao jornalista 
organizar a experiência do escândalo, as sequências, a reconstituição no tempo de transgressões cometidas no passado, identificar os indivíduos implicados, as personagens, aproximando, naturalmente, a reconstrução do fenómeno à realidade, ao referente. Não devemos esquecer que o texto jornalístico é uma "recriação linguística" dos acontecimentos e o escândalo mediático, por ser normalmente um acontecimento complexo e disruptivo que se desenvolve durante vários dias, semanas ou meses, obedece a um plano de organização estrutural que se caracteriza pela sucessão dos eventos de forma encadeada e, naturalmente, segundo estratégias discursivas que organizam, contextualizam e explicam os acontecimentos que estão na base da sua eclosão.

Nesta linha de pensamento, a comunicação mediatizada, ao converter o escândalo num acontecimento selecionado, enquadrado e divulgado pelo medium, acaba por organizar a narrativa do escândalo sob a forma de intriga diegética. Na nossa perspetiva, os escândalos mediáticos apresentam uma dinâmica comunicativa que adquire significações e representações na medida em que a ação se vai reconfigurando, se vai reconstruindo na esfera mediática e nas notícias da imprensa. Neste processo de recomposição do escândalo, as componentes linguísticas ganham uma significação que possibilita a reconstrução do enredo jornalístico, a sua fragmentação, reconfiguração em episódios, em momentos de maior e menor cobertura mediática, em cenas e em personagens que realizam determinadas funções no desenrolar dos acontecimentos. Isso significa que podemos interpretar os escândalos mediáticos como narrativas complexas que se desenvolvem na imprensa, "estórias" que têm um enredo, episódios principais e secundários, personagens, e efeitos de sentido inerentes ao trabalho de recomposição do jornalismo no momento de converter o fenómeno numa experiência mediática, numa experiência instituída pelo campo da imprensa que pode ser apreendida e experimentada pelo público. 
O filósofo italiano Gianni Vattimo caracteriza este fenómeno de "mundo fantasmático dos mass media" (Vattimo, 1989), um mundo onde as notícias sobre os acontecimentos do mundo real surgem, muitas vezes, como uma "novela", como uma "fábula", uma intriga mediática urdida pelos jogos de linguagem que são inerentes ao jornalismo e que, mais do que representar meramente a realidade, a enquadram sob determinados ângulos, a moldam, a configuram, a instituem, atribuindo-lhes de forma seletiva particularidades ou características específicas.

A configuração narrativa do escândalo permite a experimentação da realidade, a fácil apreensão da complexidade dos acontecimentos e o estabelecimento de uma visão integrada do fenómeno. É a narratividade que ordena o acontecimento, que determina as suas conexões, que liga os eventos e os elementos dispersos, organizando, por conseguinte, o sentido. Tal como sublinha Ricoeur "as questões "quem", "o quê", "como", "porquê" e outras estão já contidas na inteligência narrativa" (1985: 35), e, neste sentido, a compreensão dos acontecimentos do mundo da vida faz-se pela via da narratividade, pois é a narrativa que reordena os acontecimentos e que contribui para a sua compreensão e explicação. Não obstante, é importante referir que a linguagem jornalística não recria exatamente o mundo da vida, o real, mas apenas consegue recompor essa realidade, produzindo um discurso verosímil, um "efeito de realidade". É por isso que os acontecimentos relatados acabam por estar fortemente impregnados de subjetividade, quer na sua enunciação, quer no ato de receção por parte do leitor/ espectador, ainda que a enunciação jornalística seja, naturalmente, caracterizada pela autenticidade expressiva do locutor. Por outro lado, deve acrescentar-se que a configuração narrativa dos acontecimentos públicos é fortemente marcada ou caracterizada por contextos pragmáticos e pelas pretensões do narrador no momento de costurar o ato narrativo. Assim, as narrativas de 
imprensa não são, com efeito, ingénuas ou construídas aleatoriamente, mas são, antes, caracterizadas pela atitude argumentativa do narrador, pelas conexões que este estabelece entre os eventos e, naturalmente, pelos efeitos de sentido que evoca nos destinatários. Mais do que relatar literalmente a realidade, as narrativas da imprensa estão impregnadas de jogos de linguagem que despertam uma certa experiência estética no momento da sua receção e apreensão, independentemente da necessária aproximação do discurso produzido à realidade objetiva, referencial. Todavia, e tal como contundentemente assinala Motta, "toda versão sobre o real é uma interpretação dele, e toda versão trai porque é uma versão entre tantas outras possíveis: não é o facto em si mesmo" (Motta, 2013: 40).

Produzindo efeitos fácticos ou fictícios, a configuração narrativa dos acontecimentos públicos construída pelo campo do jornalismo articula os antecedentes e os consequentes, as ações realizadas por personagens, as causas e as consequências dessas ações, a temporalidade e a serialidade dos acontecimentos, em suma, uma síntese de elementos heterogéneos e fragmentados que são colocados em relação, que são ordenados, configurados, convertidos numa totalidade que pode ser compreendida, apreendida pelos destinatários. No fundo, trata-se de estabelecer relações lógicas e causais entre acontecimentos passados, recorrendo a um encadeamento temporal e cronológico e a um conjunto de recursos explicativos que possibilitam quer a inteligibilidade, quer a "experimentação" dos acontecimentos.

Com efeito, a descrição do mundo prático da ação é possibilitada pela mise en intrigue, isto é, pela configuração e estruturação dos acontecimentos mediante uma rede de intersignificação que integra os elementos da ação numa lógica, numa composição ou totalidade inteligível. Como, a propósito, sublinha Adam, "a atividade narrativa combina uma ordem cronológica e uma ordem configuracional" 
(1984: 17) que integra elementos heterogéneos numa composição ordenada, articulando o acontecimento e, consequentemente, configurando-o. Neste ponto, os relatos informativos acabam por atribuir particularidades específicas ou determinados pormenores aos acontecimentos públicos, e fazem-no de forma "seletiva" (Tuchman, 2003: 97), produzindo, simultaneamente, sentidos culturais, políticos ou ideológicos. O jornalista assume-se como o sujeito enunciador, como a voz narrativa responsável pela interlocução e pela construção de posições factuais e referenciais, mas também por posições poéticas, estéticas e ficcionais.

\section{Quando o escândalo se converte em "estória": o caso Face Oculta}

Uma das funções primordiais dos media consiste em inscrever o fluxo dos acontecimentos na história, organizando para o leitor/ espectador os eventos do mundo da vida mediante sequências lógicas, ao mesmo tempo que alimentam o imaginário do público (Lits, 2008: 126). Se, neste texto, temos procurado interpretar os escândalos mediáticos como narrativas complexas que se desenvolvem na esfera pública devido à ação do medium, talvez seja pertinente, agora, ilustrar o nosso trabalho com uma breve análise pragmática de um dos escândalos mais mediáticos dos últimos anos da política portuguesa, o caso Face Oculta. Analisando a cobertura jornalística do Semanário Sol num período determinado, procuraremos demonstrar de que forma o ato de fala narrativo organizou o acontecimento, as suas sequências e episódios, a caracterização das personagens envolvidas e o uso de artimanhas enunciativas que tiveram como propósito criar efeitos de real e efeitos de sentido.

Efetivamente, por um lado, a análise do escândalo Face Oculta permite-nos observar a recomposição de notícias sobre um mesmo tema ou assunto num acontecimento eminentemente dramático onde 
é possível acompanhar o desdobramento de episódios, a caracterização de personagens, os papéis desempenhados, a presença de conflitos, enfim, a representação do real. Por outro lado, também nos permite compreender os escândalos mediáticos como narrativas, como "estórias jornalísticas" que se vão desdobrando em plots principais e secundários aos quais a poética jornalística vai acrescentando novos dados e aumentando a sua própria complexidade. O caso foi publicitado pela imprensa nos meses de outubro e novembro de 2009 e arrastou-se até setembro de 2014, altura em que todos os arguidos foram condenados. Como facilmente se constata, o escândalo teve um desenvolvimento temporal bastante longo, algo que se explica pelo facto de se ter constituído como um processo jurídico. Precisamente do ponto de vista judicial, foi dada como provada a existência de uma associação criminosa que obtinha, para a empresa O2 liderada por Manuel Godinho, benefícios em concursos públicos através de uma rede de tráfico de influências que envolvia altos quadros do Executivo liderado pelo primeiro-ministro de então, José Sócrates. Entre os 34 indivíduos acusados, encontrava-se Armanda Vara, ex-ministro pelo Partido Socialista e amigo de José Sócrates.

Do ponto de vista jurídico, o escândalo Face Oculta enquadra-se na tipologia de escândalo político-financeiro, pois revelou a existência de laços ocultos entre o poder político e o poder económico que serviriam para beneficiar empresas privadas mediante a má utilização ou má gestão de recursos públicos. Não obstante, das escutas telefónicas obtidas durante a investigação a Armando Vara, faziam parte conversas entre este protagonista e José Sócrates, conversas que, segundo o Ministério Público, levantavam suspeitas de que o governo teria tentado utilizar a empresa Portugal Telecom para comprar a estação televisiva TVI e, assim, influir no conteúdo das notícias veiculadas por este órgão de informação. Por outras palavras, e voltando à terminologia adotada por Thompson, as 
escutas telefónicas revelaram a existência de "transgressões de segunda ordem" que pouco tinham que ver com o escândalo político-financeiro e que envolviam, diretamente, o primeiro-ministro. Mediante a análise de nove edições do Semanário Sol sobre o tema, de 6 de novembro de 2009 a 12 de fevereiro de 2010, período em que a cobertura mediática foi mais intensa, é possível recompor as sequências do escândalo, identificar a presença de personagens, reordenar a cronologia jornalística, isto é, recompor um enredo, ligar as partes, unir as pontas-soltas, reconstruindo ou refigurando uma estória jornalística, a narrativa de um escândalo mediático. Como refere Motta, na esteira de Paul Ricoeur, "a reconfiguração do acontecimento-intriga tem o mágico poder de tecer a totalidade da estória e realizar a função de integração e de mediação da intriga" (Motta, 2013: 99). Ora, a complexidade e o desdobramento do escândalo tornam-se visíveis logo na edição de 6 de novembro de 2011. A informação de que o primeiro-ministro foi interceptado nas escutas a Armando Vara ganha destaque em relação ao que seria, tendencialmente, um escândalo financeiro. Por outro lado, a partir deste momento, José Sócrates, que não foi constituído arguido no caso, adquire uma certa proeminência na intriga. O Semanário Sol posiciona o então primeiro-ministro como uma das personagens do escândalo com a manchete: "Sócrates escutado em conversas com Vara". A edição acrescenta novos dados ao caso, ao referir que das escutas telefónicas efetuadas a Armando Vara surgiram "novos indícios" que foram enviados ao Procurador-Geral da República, Pinto Monteiro, indícios relacionados com o negócio PT/TVI. Nesta edição é, ainda, possível identificar a personalização do acontecimento mediante um enquadramento poético. Recorrendo a um frame lúdico em forma de teia com o título: "a teia de influências do Face Oculta", o jornalista personaliza o escândalo, posiciona as personagens, identifica os papéis desempenhados por estas, as suas funções: 


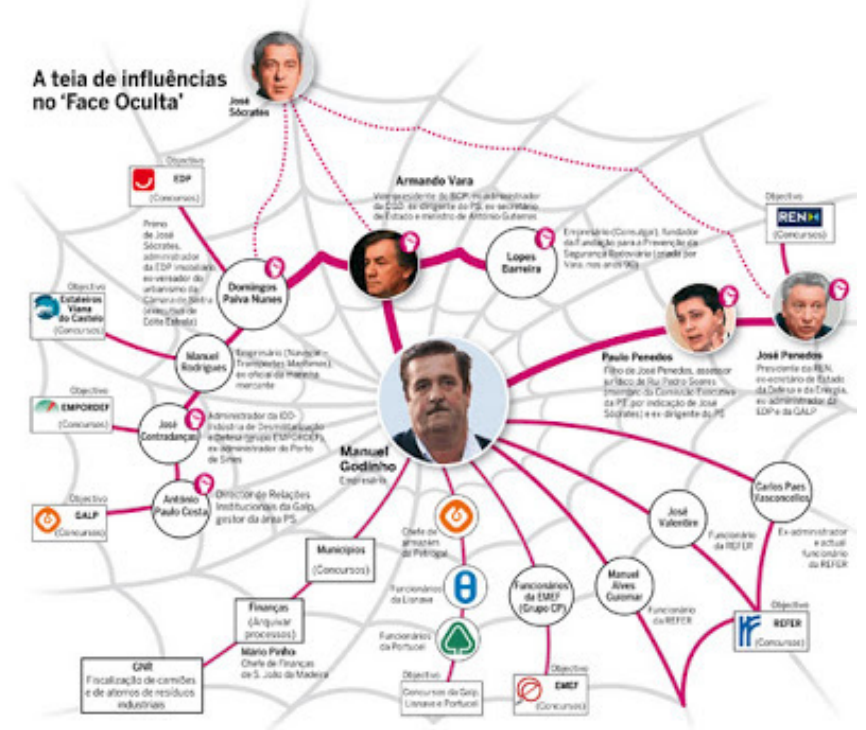

Figura 1: A teia de influências do Face Oculta. Semanário Sol, 6/11/2009.

Os actantes são identificados na narrativa mediante o posicionamento que o jornalista lhes confere, mediante uma certa hierarquia que visa despertar determinados efeitos no leitor. As personagens são colocadas em relação umas com as outras e tendo em conta o papel que cada uma desempenha na intriga. José Sócrates, apesar de não estar indiciado de quaisquer crimes, é identificado como aquilo que podemos designar por "actante dominante", verificando-se uma certa proeminência que o então primeiro-ministro acabou por adquirir no relacionamento estabelecido entre todos os envolvidos. As narrativas necessitam de personagens e o escândalo mediático tem, necessariamente, as suas dramatis personae, personagens que realizam determinadas ações e que, no caso específico do escândalo, são identificados como "transgressores" ou "purificadores", como vilões ou heróis.

Nas edições seguintes e à medida que são acrescentados novos dados ao escândalo, a narrativa mediática reconfigura-se, ganha 
novos episódios e novos conflitos. Cruzando o teor das conversas filtradas entre Sócrates e Armando Vara sobre a possibilidade de a PT comprar a TVI, com declarações públicas do primeiro-ministro prestadas num debate parlamentar no dia 24 de junho de 2009, o jornal acrescenta "transgressões de segunda ordem" à narrativa concluindo que "José Sócrates mentiu ao Parlamento sobre a TVI". De um escândalo eminentemente político-financeiro, o Face Oculta converte-se num escândalo de poder, num evento politizado que envolve a derrogação dos procedimentos normativos que regem o exercício do poder político. A edição de 13 de novembro de 2009 recorre ao flashback para recuperar o momento em que José Sócrates declarou, perante os deputados, não ter conhecimento das negociações entre a PT e a Prisa, dona da TVI, desconhecimento contrariado pelas escutas do processo Face Oculta, nomeadamente por uma conversa ocorrida em março desse mesmo ano entre o ex-primeiro-ministro e Armanda Vara. O narrador recorre ao frame temporal e cronológico para legitimar a sua fala, isto é, comprovar as novas transgressões. Reconstruindo os momentos mais significativos deste episódio, o jornalista recupera declarações proferidas no passado, resgata os antecedentes, para chegar à significação, à conclusão: "Sócrates mentiu no Parlamento”. Efetivamente, o momento da hipotética mentira parlamentar de José Sócrates constituiu-se como uma unidade temática do escândalo relativamente autónoma em relação "às transgressões de primeira ordem", podendo distinguir-se como um episódio ou uma parte da estória. Não obstante, trata-se de um episódio que ofereceu uma nova dinâmica à estória e que, de certa forma, fez progredir a narrativa mediática na direção de novas transgressões, animando e adensando o debate público. Novas transgressões que haveriam de ser divulgadas durante o mês de fevereiro, momento em que o caso adquiriu outros contornos devido à divulgação do conteúdo das escutas telefónicas entre Armando Vara e José Sócrates. A edição de 5 de fevereiro, intitulada "As escutas proibidas", revela a existência de 
um plano que envolvia o primeiro-ministro para controlar a estação televisiva e outros órgãos de informação. Se, num primeiro momento da narrativa, a operação judicial denominada Face Oculta começou por ter como objeto apurar as atividades ilícitas resultantes de uma "rede tentacular" que visava beneficiar as empresas de Manuel Godinho na adjudicação de obras públicas, as escutas telefónicas efetuadas a Armando Vara revelaram a existência de situações marginais ao escopo da investigação que, pelo seu conteúdo, representavam "um sério atropelo aos mais elementares princípios por que se devem nortear os Estados democráticos" $" 58$.

De acordo com as novas denúncias que são acrescentadas ao escândalo, o plano passava por afastar a jornalista Manuela Moura Guedes da TVI, aparentemente porque às sextas-feiras Manuela Moura Guedes abria o Jornal Nacional com notícias incómodas para o Governo relacionadas com um outro escândalo, o caso Freeport. ${ }^{59}$ Porém, e uma vez que para afastar Manuela Moura Guedes da TVI era necessário afastar o diretor da estação de Queluz e marido da jornalista, José Eduardo Moniz, a operação visava tomar conta da TVI através da Portugal Telecom, empresa da qual o Estado português era acionista. A cobertura jornalística reconfigurou o caso numa nova narrativa, mais complexa, com novos episódios, novos conflitos e novas personagens. Na mesma edição, é notório como a reconfiguração do escândalo denota uma relação recíproca entre a narratividade e a temporalidade dos acontecimentos. O plano ou "esquema" é situado no tempo mediante uma extensão cronológica de desdobramento da ação em certos momentos. É, justamente, neste

\footnotetext{
${ }^{58}$ Veja-se o despacho do diretor da Polícia Judiciária de Aveiro, Teófilo Santiago, de 12 de junho de 2009 .

${ }^{59} \mathrm{O}$ nome de José Sócrates esteve associado a um outro escândalo mediático, o caso Freeport. José Sócrates tornou-se num dos suspeitos de corrupção devido a ter subscrito, enquanto ministro do Ambiente, o decreto-lei que permitiu a aprovação da construção do outlet Freeport, em Alcochete. Algumas testemunhas declararam que o então ministro do Ambiente recebeu pagamentos em dinheiro, "luvas", para viabilizar o projeto. Porém, do caso não resultou nenhuma acusação.
} 
ponto, que a temporalidade surge ligada ao próprio desenvolvimento da intriga, isto é, à capacidade de organizar os acontecimentos e, assim, contar uma "estória" unificada. O quando e o como convertem-se em elementos constitutivos da narrativa do escândalo, especificamente porque permitem situar o leitor no tempo dos acontecimentos, ajudar o jornalista/narrador a organizar o tempo enunciativo e, por conseguinte, o discurso jornalístico. É a experiência do tempo que permite que o escândalo adquira uma certa unidade, organizando os episódios em sequências que geram a compreensão e a significação do fenómeno. Expressões temporais como "no dia seguinte", "estava-se a 19 de junho", ou "nesse mesmo dia", possibilitam a reconstrução da ação, a organização das sequências que compõem o enredo e, consequentemente, o estabelecimento de uma conexão interna que é essencial para a reconfiguração mediática do fenómeno.

Desta dramatização inerente à narrativa, as personagens e a sua caracterização surgem novamente como eminente categoria, como uma categoria responsável pelo desempenho do enredo. Com efeito, o relato surge mediante a identificação e a caracterização das personagens envolvidas no escândalo. Todavia, é notório que o narrador procura colocar as personagens em relação, descrevendo cada personagem tendo em conta as relações que esta estabelece ou estabeleceu com os demais envolvidos. O rosto das personagens é colocado não apenas em destaque, mas também em relação, um frame visual que permite a identificação dos envolvidos como "transgressores". O frame visual é acompanhado pela legenda: "os pivôs do esquema".

Neste processo de identificação e caracterização das personagens, Rui Pedro Soares ${ }^{60}$, por exemplo, é descrito como um "boy socrático", como um indivíduo que, apesar de ter "falta de curriculum",

\footnotetext{
${ }^{60}$ Rui Pedro Soares era o homem de confiança do governo na Portugal Telecom. Nomeado pelo executivo liderado por José Sócrates para o cargo de administrador, foi um dos responsáveis pela planificação da tentativa de compra da TVI pela PT.
} 

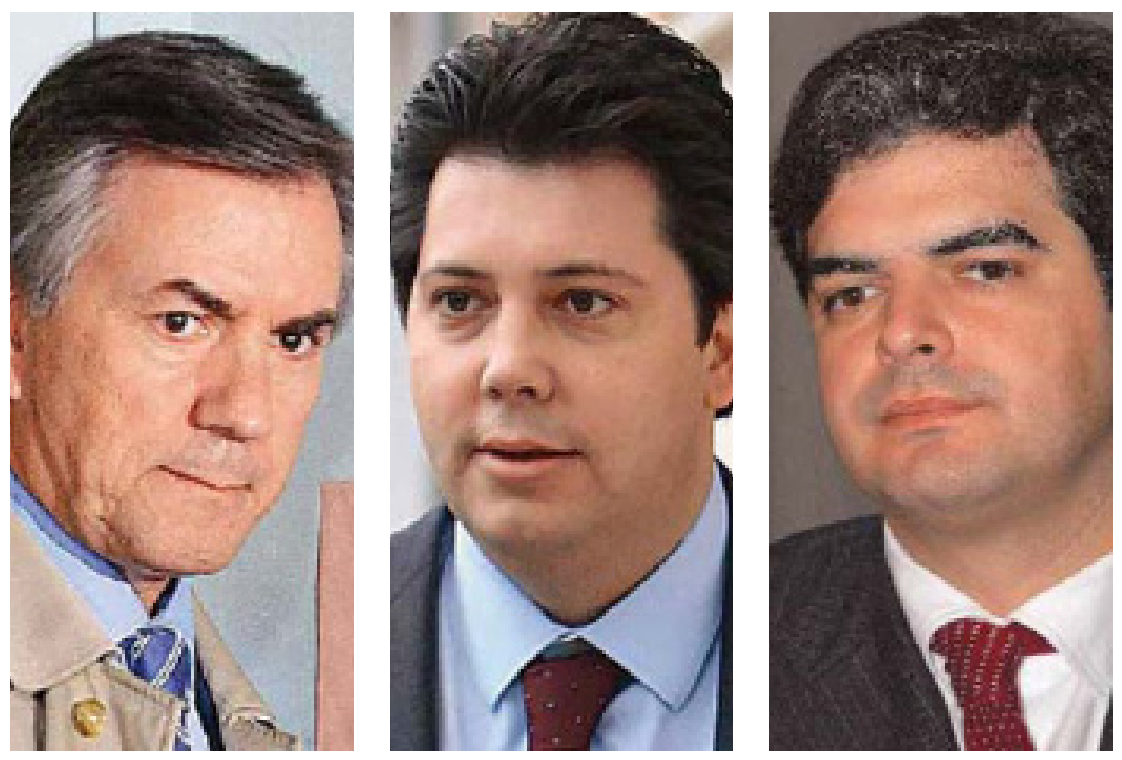

Figura 2: "Os pivôs do esquema" segundo o Semanário Sol de 5 de fevereiro de 2010.

se afirmou na empresa de telecomunicações devido à confiança em si depositada por José Sócrates. Não obstante, na identificação dos elementos-chave do escândalo, o ex-primeiro-ministro surge, novamente, como a figura central da narrativa, como o eixo do conflito em torno do qual toda a intriga se desenvolve. A centralidade de José Sócrates no escândalo torna-se de novo explícita na edição de 12 de fevereiro de 2010. Através de uma manchete metafórica, José Sócrates é identificado como a figura central da narrativa, não obstante o facto de não ter sido constituído arguido no processo. Trata-se de um enquadramento lúdico que visa significar que José Sócrates agiu de forma similar ao polvo, construindo uma "rede tentacular" que visava o controlo de meios de comunicação. Um efeito poético que ornamenta a realidade e que, simultaneamente, desperta efeitos de sentido no público. Uma estratégia intencional do narrador que ajuda a identificar Sócrates como o "actante dominante", mas que 


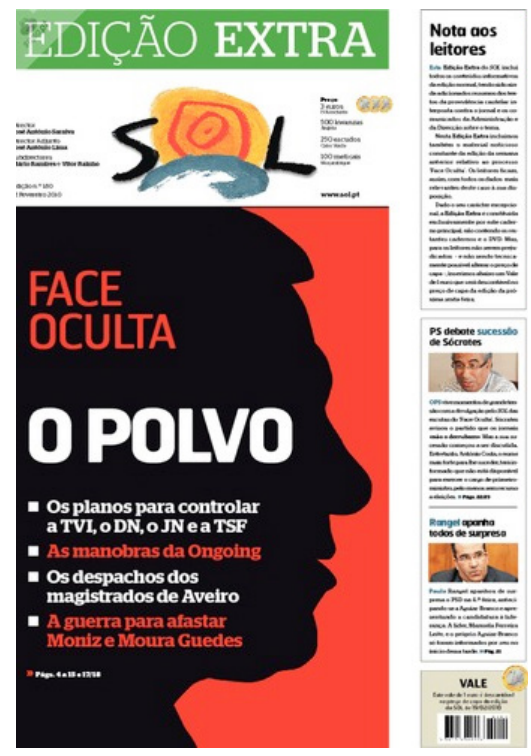

Figura 3: Manchete metafórica do Semanário Sol. 12 de fevereiro de 2010.

também ajuda a capturar a atenção pública ao gerar no público, de forma intencional ou não intencional, efeitos estéticos ou poéticos.

Como vemos, a linguagem narrativa convida o leitor ou espectador a fazer interpretações subjetivas, embora a linguagem jornalística privilegie recursos de estilo de caráter mais denotativo que conotativo, no sentido de gerar no destinatário uma apreensão quase imediata da mensagem, por motivos de economia discursiva. E, no quotidiano, a metáfora do polvo é uma das figuras de estilo mais utilizadas, sobretudo no que a assuntos da política diz respeito. De facto, a linguagem jornalística está repleta de metáforas convencionais, figuras de estilo que contêm o mínimo de "ruído" possível e que, além de ornamentarem ou embelezarem o discurso jornalístico, também assumem uma posição referencial. Efetivamente, a recomposição do escândalo nos media é quase sempre bastante rica em 
efeitos simbólicos, precisamente devido ao facto de o escândalo ser um acontecimento eminentemente dramático que suscita, no público, diversos estados de espírito.

\section{Considerações Finais}

Jornalismo, Narrativas e Escândalos procurou abordar as relações entre o jornalismo e a teoria da narrativa colocando em evidência as características eminentemente dramáticas e estéticas dos escândalos mediáticos. Na perspetiva que procurámos erigir, os escândalos mediáticos desenvolvem-se na esfera pública como narrativas complexas que têm conflitos, episódios, personagens e efeitos de sentido inerentes ao trabalho jornalístico de recomposição da realidade. O escândalo mediático apresenta-se como um processo "aberto", como um jogo de significações que adquire um certo valor expressivo e esteticizante ao configurar-se nos dispositivos de mediação simbólica. Ao apropriar-se do acontecimento para o converter em algo inteligível para o leitor, o medium combina, muitas vezes, as técnicas jornalísticas com as técnicas do universo ficcional para produzir narrativas dramáticas sobre os acontecimentos, particularmente sobre os acontecimentos da política. Neste ponto, acreditamos que os escândalos mediáticos apresentam uma dinâmica comunicativa que acaba por favorecer a sua dramatização, a sua reconfiguração numa trama, numa diegese. Com efeito, a desconstrução hermenêutica do escândalo Face Oculta demonstra que, muitas vezes, a informação surge como "novela" episódica organizada temporalmente e de onde emergem conflitos, personagens, momentos dramáticos, situações de suspense que amarram o leitor à estória e que o convidam a seguir a sua serialidade. É nesta perspetiva que consideramos que os escândalos mediáticos adquirem um enquadramento narrativo 
visível na organização textual do fenómeno, na sua fragmentação em episódios principais ou secundários, na personalização ou individualização da cobertura mediática, na definição da temporalidade dos acontecimentos, dos seus antecedentes e consequentes e numa certa composição poética inerente aos estratagemas enunciativos e à habilidade estilística do narrador/jornalista no momento de costurar o fenómeno como acontecimento mediático.

\section{REFERÊNCIAS BIBLIOGRÁFICAS}

AA.VV. (2011). Dicionário da Língua Portuguesa Contemporânea. Lisboa: Calouste Gulbenkian.

ADAM, J.M. (1984). Le Récit. Paris: Presses Universitaires de France.

ADAM, J-M; REVAZ F. (1997). A Análise da Narrativa. Lisboa: Gradiva. Apostolides, P; Williams, J.A. (2004). Public Affairs, Politics in the Age of Sex Scandals. London: Duke University Press.

ARISTÓTEleS (2005). Poética. Lisboa: Imprensa Nacional Casa da Moeda. BARTHES, R. (1973). O Prazer do Texto. Lisboa: Edições 70.

BIRD, E.; DARDENNE, R. (1999). "Mito, Registo e Estórias: explorando as qualidades narrativas das notícias", in TRAQUINA, N. (Org). Jornalismo, Questões, Teorias e "Estórias" Lisboa: Vega.

BObBIO, N. (2000). Teoria Geral da Política, a Filosofia Política e as Lições dos Clássicos, Rio de Janeiro: Elsevier Editora.

BOURDIEU, P. (1997). Sobre a Televisão. Oeiras: Celta Editora.

DAMPIERRE, E. (1954). "Thémes por l'étude du scandale", in Annales, Économies, Sociétés, Civilisations, $9^{\text {ème }}$ année, $\mathrm{N}^{\mathrm{o}} 3$.

DERRIDA, J; STIEGLER, B. (1996). Échographies de la télévision. Paris: Gallilée. LITS, M. (2008). Du Récit au récit médiatique. Bruxelles: De Boeck.

LOWI, T. (1988). "Prefácio", in MARKOVITS, A; SILVERSTEIN, M. (Org). The Politics of Scandal: Power and Processes in Liberal Democracies. New York: Holmes\&Meier Publishers. 
LOWI, T. J. (2004). "Power and Corruption, Political Competition and the Scandal Market", in APOSTOLIDIS, P.; Williams, J. A. (Org). Public Affairs, Politics in the Age of Sex Scandals. London: Duke University Press.

MARKOVITS, A; SILVERSTEIN, M. (Org). (1988). The Politics of Scandal: Power and Processes in Liberal Democracies. New York: Holmes\&Meier Publishers.

MOTTA, L.G, "Análise Pragmática da narrativa jornalística", in LAGO, C.; BENETTI, M. Metodologia da pesquisa em jornalismo. Petropólis: Vozes.

MOTTA, L.G. (2013). Análise Crítica da Narrativa. Brasília: Editora UNB.

PRIOR, H. (2013). Esfera Pública e Escândalo: o secreto no âmbito público. Tese de Doutoramento, Covilhã: Universidade da Beira Interior.

RICOEUR, P. (1983). Temps et Récit I. Paris: Le Seuil.

RICOUER, P. (1985). Temps et récit III, Le temps raconté. Paris: Le Seuil.

RICOEUR, P. (1999). Historia y Narratividad. Barcelona: Paidós.

RODRIGUES, A.D. (1984). O campo dos Media, Discursividade, Narratividade, Máquinas, Lisboa: Vega.

SEARLE, J.R. (2004). The Philosophy of language. Oxford: Oxford University Press. TODOROV, T. (1982). "Las categorias del relato literário", in Analisis Estructural del Relato. Barcelona: Ediciones Buenos Aires.

THOMPSON, J. B. (2001). El escándalo político: poder y visibilidad en la era de los medios de comunicación. Barcelona: Paidós.

TUCHMAN, G. (1999). “Contando estórias”, in TRAQUINA, N. (Org). Jornalismo, Questões, Teorias e "Estórias". Lisboa: Vega.

TUCHMAN, G. (2002). "As notícias como uma realidade construída", in ESTEVES, J.P. Comunicação e Sociedade. Lisboa: Livros Horizonte.

VATTimo, G. (1992). A Sociedade Transparente. Lisboa: Relógio D’água. 
(Página deixada propositadamente em branco.) 


\section{A MINHA VIDA NÃO DAVA UM FILME: ENSAIO DE DESCONSTRUÇÃO DA REPORTAGEM ENTRE A LITERATURA E O JORNALISMO}

Jacinto Godinho

Universidade Nova de Lisboa

Apesar de ser considerada, entre os jornalistas, como a "arte nobre do jornalismo" a reportagem tem sem dúvida um estatuto menor no painel das narrativas modernas, especialmente se a compararmos com as mais relevantes categorias da literatura (novela, conto, poema) do cinema (filme, documentário) do teatro ou da música (ópera) por exemplo.

Não que a reportagem seja uma narrativa menor (apesar de nos últimos anos ter vindo a ceder espaço nos media para o comentário), mas porque, ecoando Foucault, nas formações discursivas de cada época constitui-se uma escala de valores entre saberes originada a partir do jogo do poder.

A cultura não celebra as reportagens e os seus autores da mesma forma que as ficções literárias e cinematográficas distinguidas com prémios de visibilidade planetária como o Nobel ou os Oscar.

Fora do campo jornalístico não há reportagens que façam história, que figurem nos livros de escola. Em busca de estatuto, alguns repórteres tornam-se autores de livros de ficção. Outros publicam as suas reportagens em livros. Muitos livros se escreveram baseados em 
trabalhos antes publicados na imprensa (A Sangue Frio de Truman Capote, Balada da Praia dos Cães de José Cardoso Pires) e muitos nomes célebres da literatura foram primeiro jornalistas como Gabriel Garcia Márquez, Ernest Hemingway, Mark Twain. Em Portugal, entre inúmeros casos, podemos destacar alguns nomes como Aquilino Ribeiro, Raul Brandão, José Saramago, Miguel Sousa Tavares, José Rodrigues dos Santos. Para muitos destes jornalistas o treino de escrita de reportagem é assumido, com orgulho, como um patamar essencial para se tornarem escritores, ou seja, praticam a reportagem como etapa antes da literatura. Mas não deveria ser antes o oposto, ou seja, o ensaio livre da literatura como antecâmara para a difícil, complexa e muito responsável escrita do real?

Justifica-se, portanto, iniciar esta reflexão analítica com a pergunta já antes formulada por Elisabeth Eide em What novels can do, and journalism can not? ${ }^{61}$, ou seja, o que conseguem as novelas que o jornalismo não consegue?

Uma outra forma de colocar o problema é questionar por que dizemos normalmente "a minha vida dava um filme" e não dizemos "a minha vida dava uma reportagem".

Porque nunca conseguiram os repórteres ter lugar nos panteões da cultura, se a matéria das suas histórias é a vida real e tantas vezes o alimento dos romancistas?

Como resolver o paradoxo de o jornalismo e de o poder mediático serem centrais no espaço público moderno e mesmo assim não conseguirem "fazer ver e fazer falar" (Deleuze, 1986) as suas melhores obras na história?

Levando em conta os critérios de Foucault, será a narrativa de reportagem um saber sujeitado, que pertence "a toda uma classe de saberes que estavam desqualificados como saberes não conceptuais,

\footnotetext{
${ }^{61}$ Eide, Elisabeth. "What novels can do, and journalism can not. On the relationship between fiction and reportage". http://home.hio.no/ elisabe/english.htm [cons. 13-7-2015]
} 
como saberes insuficientemente elaborados, saberes ingénuos, saberes hierarquicamente inferiores." (Foucault, 1975: 11-12).

Entre as muitas razões para esta possível "sujeitação" estará, sem dúvida, o histórico conflito entre a filosofia e o jornalismo. Desde o século XVIII que a narrativa jornalística tem sido fortemente submetida a uma forte desqualificação pelo predominante e hegemónico discurso científico, por não se enquadrar nos postulados de cientificidade. Aliás, tanto "jornalista" como "reportagem" começaram por ser dois nomes estigmatizados destinados a rebaixar a atividade que passaram a referir. Denis Diderot qualificou na Encyclopédie os jornais de "publicações que são o alimento do ignorante, o recurso de quem quer falar e julgar sem ler, o flagelo e nojo de quem trabalha. Eles nunca ajudaram um bom espírito a produzir uma boa escrita; ou impediram um escritor ruim de fazer um livro ruim." (Diderot, 1766). Voltaire nos seus Conseils à un Journaliste conclui a lição suspirando:

\footnotetext{
Quisera Deus que fosse fácil remediar o mal que produzem todos os dias tantos escritos mercenários, tantos estratos infiéis, tantas mentiras e calúnias com que a imprensa inunda a república das letras! (Voltaire, 1737: 41)
}

"Jornalista" e "reportagem" eram, portanto, representações achincalhantes no discurso das elites antes de se naturalizarem como nomes sérios e neutros na cultura moderna. Este processo de desqualificação da reportagem culminou naquilo que apelidámos a "maldição de Mallarmé" (Godinho, 2009).

Num pequeno, mas célebre, texto de 1897 intitulado Crise de Vers Mallarmé procura refundar a essência da literatura opondo-a dialeticamente ao que chamou a "universal reportagem". Para Mallarmé a literatura na sua essência é o verso livre. Livre de rimas, de métrica, de melodia e de história. A isso se opõe a escrita utilitária, feita 
de truques comerciais para agradar aos outros, vendendo fórmulas repetidas disfarçadas de novidades. Tudo o que é odioso na escrita encaixa na "universal reportagem".

Mallarmé usou, portanto, a palavra reportagem como critério negativo de uma ideologia que a opunha ao conceito raro de literatura, prolongando-lhe o estigma no campo das artes. Tese mais tarde continuada pelos surrealistas. Breton apelidou de "devorador", "cretinizante" confucionista o jornalismo ${ }^{62}$. O surrealismo foi um dos movimentos que mais insistiu na separação entre "obras vivas" e "escritos de jornal", contribuindo para uma das oposições emblemáticas do século XX, o par literatura vs. jornalismo.

Talvez a "maldição de Mallarmé", prolongada pelo século XX e até aos nossos dias, explique ou seja sintoma do fraco investimento académico no estudo e entendimento das especificidades narrativas da reportagem, das técnicas e da forma como se inscreve na experiência.

Este ensaio procura, portanto, aprofundar uma análise já antes iniciada a partir da pergunta "O que é a reportagem?" (Godinho, 2009) para aclarar os princípios narrativos da experiência que a sustenta e, assim, entrar com fundamento no debate entre jornalismo e literatura.

John Carey no seu livro The Faber Book of Reportage define como critério fundamental para definir uma reportagem o relato diretamente observável pelo próprio ou por testemunhas (Carey, 1996). Carey considera mesmo alguns excertos de livros de ficção como momentos de escrita de reportagem porque são relatos tão credíveis que só podem ter sido baseados em experiências reais. Aponta o caso da descrição que Stendhal faz da batalha de Waterloo através do testemunho do protagonista Fabrício. Trata-se de uma ficção mas com uma coerência muito verosímil:

\footnotetext{
${ }^{62}$ Breton, André - "Legitime defense" (1926), Point du jour, Gallimard, Coll "Idées", pp. 33-36.
} 
Havia já muito tempo que Fabrício deixara de ver a terra voando em migalhas sob a ação de metralha. Chegaram à retaguarda dum regimento de couraceiros. Fabrício ouvia distintamente os biscainhos batendo as couraças e viu cair alguns homens.

O Sol já estava muito baixo no horizonte, e ia pôr-se quando a escolta, saindo dum caminho profundo, subiu uma pequena rampa de três ou quatro pés para entrar num campo lavrado. Fabrício distinguiu a seu lado um ruído estranho; voltou a cabeça: quatro homens tinham caído com os cavalos; o próprio general havia sido derrubado, mas já se erguia, todo coberto de sangue. Fabrício contemplava os hussardos caídos por terra: três tinham ainda alguns movimentos convulsivos, o quarto gritava: Tirem-me daqui debaixo! O sargento e dois ou três homens tinham-se apeado para socorrer o general que, apoiando-se ao seu ajudante-de-campo, tentava dar alguns passos; procurava afastar-se do cavalo, que se debatia por terra, dando coices furibundos (Stendhal, 1974:55).

O princípio da observação direta postulado por Carey coloca o seguinte problema: será que não se podem fazer reportagens de fenómenos não diretamente observáveis como a corrupção, a inflação, a depressão por exemplo? Fenómenos complexos e normalmente apresentados em reportagens através de casos escolhidos como emblemáticos como se de apenas uma árvore se conseguisse ver toda a floresta.

O princípio do diretamente testemunhável parece ser limitado no seu empirismo básico. Mas na reportagem existe uma ligação íntima entre o olhar e a palavra. Se entendermos o princípio de Carey como uma base de trabalho isso significa que a prática da reportagem exige que os repórteres procurem, mesmo nos casos mais complexos, o que pode ser diretamente observável. 
Por exemplo, tomemos o caso da inflação, um real abstrato. Para tratar um fenómeno destes um repórter normalmente pega no modelo da tese académica, divide o tema em várias categorias, como a política, a economia, a jurídica, etc., procura para cada uma um especialista, alterna o seu testemunho com uma série de exemplos escolhidos ao acaso de produtos que subiram ou desceram de preço e acrescenta-lhe vozes populares (Voz Off) escolhidas ao acaso numa mercearia ou supermercado. No final, tudo reunido, é chamado uma reportagem mas parece antes catálogo ideológico. Se a orientação for o "diretamente observável", é necessário refazer a pesquisa e o guião narrativo, partindo em busca do que, no tema inflação, pode ser realmente testemunhado.

Como é realmente calculada a inflação? Que organismo faz os cálculos? Como os faz no terreno, ou seja, que produtos são monitorizados e por quem? Para seguir esta linha narrativa a reportagem precisa de tempo. A reportagem está mais do lado de uma narrativa temporal do que de uma narrativa sincrónica. Mas como funciona o testemunho, o diretamente observável, no circuito da palavra? Como é que o olhar se preserva na palavra e como guarda a reportagem a legitimidade de fazer acreditar que os acontecimentos relatados aconteceram realmente?

Regressemos então à pergunta: "o que é a reportagem?”

Quem melhor pode orientar nesta pergunta ontológica é Martin Heidegger. Heidegger não se interroga diretamente sobre a reportagem mas sobre a filosofia. Heidegger sustenta que a cultura ocidental é, no seu caminho mais íntimo, originariamente filosófica. Isto não significa que a filosofia seja a fundadora da civilização ocidental. Significa que é a filosofia quem pergunta pelo ser das coisas. As narrativas científicas estão organizadas a partir da pergunta "o que é?" por exemplo: o que é o sistema solar, um terramoto, a doença, a vida, a morte, etc.

O jornalismo, à sua maneira, também pergunta pelo ser das coisas, interrogando a atualidade: o que é a crise, o desemprego, a violência 
doméstica e assim sucessivamente. A pergunta pelo ser está enraizada tanto no núcleo mais profundo do nosso sistema epistemológico como na banalidade dos saberes quotidianos.

A filosofia vai mais longe e pergunta por que é que nós perguntamos pelo ser das coisas. A pergunta pelo ser é o motor da cultura ocidental. Mas a variedade de articulações narrativas que a pergunta do ser permite é enorme.

Walter Benjamin no ensaio "O Narrador" afirma que a tradição da narrativa tradicional não conduz a uma explicação:

\footnotetext{
Cada manhã recebemos notícias de todo o mundo. E, no entanto, somos pobres em histórias surpreendentes. A razão é que os factos já nos chegam acompanhados de explicações. Em outras palavras: quase nada do que acontece está ao serviço da narrativa, e quase tudo está a serviço da informação. Metade da arte narrativa está em evitar explicações. (Benjamin, 1994: 203).
}

Quando colocados perante a pergunta "o que é a reportagem?", somos automaticamente instalados numa situação de ignorância a que é prometida a revelação de um segredo. A expectativa da revelação é tão forte que podemos ser iludidos com a sugestão de uma explicação que promete finalmente esclarecer mas que não explica nada.

Será que responder à pergunta "o que é a reportagem?" nos ajuda a esclarecer a narrativa da reportagem e ajuda a fazer reportagens? Estamos a interrogar a prática da reportagem, apenas questionamos a palavra ou visamos a categoria linguística? Cada uma destas condições do ser encaixa-se na palavra reportagem mas não são a mesma coisa.

A prática da reportagem já se fazia muito antes de surgir o conceito. O conceito de reportagem, com a consistência de género jornalístico, só surgiu no final do séc. XIX. 
Será que o nome refere todo o universo da reportagem? Será que é a palavra certa para representar a experiência narrativa que se exerce através da prática da reportagem?

Será que não ilumina apenas um dos lados, o campo jornalístico, anulando ou ocultando os outros campos narrativos atravessados pelo reportar?

Será que não é a própria palavra reportagem, pouco nobre, sem carisma, a responsável pelas narrativas de reportagens serem um saber sujeitado, ou consideradas uma arte menor?

Quando perguntamos pela ontologia da reportagem podemos incluir a perspetiva historicista e perguntar o seguinte: o que aconteceu nas práticas de escrita do real para que, a partir de determinada altura, fossem nomeados pela palavra reportagem?

Esta é a tese defendida por Matilde Rosa Araújo em "A Reportagem como género: génese do jornalismo através do constante histórico-literário":

Com um bocadinho de boa vontade podíamos criar uma tese: que o jornalismo nasceu do verso, como a poesia esteve condenada (felizmente) a fazer nascer a nossa literatura. As notícias infiltram-se. Vem de longe terras, polidas arredondadas, como as pedras de um rio: chegam cá seixos de ribeira (Araújo, 1946: 93).

Rosa Araújo argumenta que já era reportagem aquilo a que no tempo de Fernão Lopes e Pero Vaz Caminha se chamava crónica e que estes terão tido "a arte de chamamento de um verdadeiro repórter artístico e não o empalhado clássico da história" (Araújo, 1946: 101).

Será através do palimpsesto da palavra reportagem que podemos entender o processo de experiência que o ato de reportar, ou melhor o dispositivo da reportagem, põe em marcha? 
Numa anterior investigação seguimos a desconstrução etimológica para chegar à essência da reportagem (Godinho, 2009). No fundo, tentámos interrogar a palavra tentando perceber como ela se pensa e pensa a experiência que produz e que a produz. A base da palavra reportagem é o verbo latim portare que significa "portar" ou "transportar" (Silva, 2014). Se entendermos o portare como "trazer" ou "levar", o prefixo re de reportagem indica, então, que reportar é "trazer novamente" ou "levar de volta". Indica uma repetição do movimento. Esta repetição por mais estranho que pareça é a condição fundamental da narrativa ou, melhor, do dispositivo narrativo.

A narrativa se transporta algo permite-o também transportar de novo. É um caminho que se abre e fica em aberto. É esse o dispositivo. Esta faculdade de uma palavra, como a reportagem, que significa um género narrativo e cuja etimologia apenas aponta para um movimento básico do viver que é transportar, ou carregar, sem indiciar algo mais que clarifique o dispositivo, promete conduzir a análise a um bizarro labirinto.

O que é que se transporta ou carrega? O que é se movimenta ou mobiliza? E o que é que isso tem a ver com o jornalismo?

Uma outra palavra que está muito próxima da palavra reportagem é a palavra "relato" e que por vezes se usa como sinónimo. No latim o significado de relato confunde-se com o de reportar. Relato pode vir de relatus que também significa "carregar", ainda que no sentido de trazer à memória, recordar, ou de relatio ou seja "relativo a" ou "relacionado com". A narrativa de reportagem sendo relato, carrega e transporta para a memória. O quê? Temos duas hipóteses. Os relatos falam de acontecimentos. Portanto, ou se transportam os acontecimentos a alguém ou alguém é transportado até aos acontecimentos.

O essencial neste argumento não é entender a reportagem como o que circula por todo o lado como se fosse uma rede de distribuição dos acontecimentos através das palavras. A reportagem, como narrativa de acontecimentos, configura um dispositivo especial 
que permite estender a básica matriz corporal da experiência. Permite integrar o indivíduo num dispositivo onde viaja junto com os acontecimentos. Dentro das narrativas os acontecimentos viajam, na medida em que são reportados, trazidos de novo à presença mas os sujeitos, na qualidade de leitores, ouvintes ou espectadores também "viajam” (ainda que só através da imaginação) até ao tempo e espaço dos acontecimentos. Dentro das narrativas os acontecimentos tornam-se presentes de novo e por isso se diz que são representados.

O importante a reter, nesta fase da argumentação, é que a faculdade para a qual a palavra reportagem aponta como sinal é para um caminho ou uma porta na experiência. Um caminho que amplia a consciência e uma porta que permite estender as condições de experiência para além do corpo natural. Como é que se justificam, para o sujeito, estas necessidades de movimentação dentro da palavra, de transladação possibilitada pela narrativa e como é que isto nos conduz ao jornalismo?

Deonísio da Silva acrescenta a caminho e porta, a palavra porto porque "na origem remota é a raiz do verbo latino portare, trazer do porto, levar do porto, sentido primitivo que depois se desdobrou em outros tantos significados semelhantes como conduzir, acompanhar, enviar." (Silva, 2014) “Trazer do porto" ou "levar ao porto" são belas imagens que aproximam a palavra reportagem de uma das genuínas atividades do jornalismo, buscando os barcos que chegavam já que era nos portos marítimos que fervilhavam as primeiras notícias e ancoravam todas as histórias de outras paragens.

Também numa anterior investigação (Godinho, 2009) ligámos a essência da reportagem ao antigo vocábulo grego legein o que nos vai permitir aprofundar a reflexão sobre a experiência que se faz dentro de uma narrativa.

Legein ainda hoje é a palavra que os gregos usam para nomear relato e reportagem. Como afirma Manuel António Castro, legein é 
uma palavra fundamental onde "todos os significados estão referenciados pela dinâmica poética da linguagem"63.

Também Heidegger afirma que o fundamental do logos retirámo-lo do legein: "O que é o logos retiramo-lo do legein. O que significa legein? Toda a gente que conheça esta língua sabe: legein significa dizer e falar" (Heidegger, 1994:179). No grego antigo legein significa dizer, relatar, falar, contar, ler. Mas associado ao legein está também o colocar e o posicionar. Temos mais uma vez associada à palavra reportagem, duas vias. Uma diríamos mais verbal e outra mais prática. Será que neste quadro de origem primitiva associada à essência da narrativa de reportagem ficou inscrita apenas a linhagem mais verbal? Como podemos aplicar este fundo do legein, com vários sinónimos, num quadro de pensamento que aprofunde o entendimento da experiência narrativa?

"Colocar diante" é pôr. Colocar várias coisas diante é com-pôr. Uma composição é, portanto, recolher coisas e colocá-las diante do olhar. Dispor para compor. Isto dá-nos uma outra visão para o ler e escrever mas também para o contar. É por esta interpretação conduzida pela via prática do legein que podemos entender porque é que o contar é também sinónimo de narrar, como é que o conto (álgebra) é também conto ou seja uma história como forma de comunicação.

Contar algo a alguém é enumerar coisas, factos, dados, incidentes, ou seja, a reunir tudo numa trama de acontecimentos. É juntar esses dados, compondo-os e dispondo-os para alguém. Contar uma história é alinhar esses dados de maneira a que em conjunto ganhem sentido para outrem.

\footnotetext{
63 "O radical indo-europeu - lg- de legein tem, ao longo do percurso ocidental, realizado toda essa rica gama de significados. Portanto, na raiz de todo é e/ou não-é age a força de legein, uma força de produzir tensões e integrar conflitos, dialeticamente. Dessa maneira, todos os significados de legein estão referenciados pela dinâmica poética da linguagem”. Toda essa rica gama diz respeito a: « $1^{\mathrm{a}}$. Reunir e concentrar; $2^{\mathrm{a}}$. Pausar, assentar e repousar; $3^{\text {a }}$. Listar, relacionar, narrar ou ditar. Só reúne e discerne quem de antemão já vigora no aprender e compreender. É assim que são possibilitados o dizer, as narrativas, a leitura e o diálogo» (Castro, 2013: 14).
} 
Quando contamos algo a alguém, quando escrevemos ou lemos uma narrativa, estamos no fundo a repetir o gesto de um agricultor que colhe, reúne, dispõe e guarda e, assim, produz alimento. Por isso da arte de narrar se extrai o essencial daquilo que se chama a cultura de um povo e o repórter é também, como recoletor, agente de cultura. Percebemos agora, por esta análise conduzida a partir da origem primitiva da reportagem como legein, que o transportar, a mobilização que o dispositivo da reportagem permite, não é o fim pensável do processo narrativo. Reportar não é apenas trazer a alguém os acontecimentos antes ocorridos, "Aquiles morreu", "Ulisses regressou finalmente a Ítaca", "José Sócrates, o ex-primeiro ministro, foi preso".

A reportagem é um dispositivo de mobilização que permite ao leitor/ouvinte/espectador repetir os passos do repórter. É um contar mas fazendo com que o leitor "calce os sapatos" e repita os movimentos do repórter. É esta a experiência que a reportagem permite, uma forma de experimentar os acontecimentos, num processo, numa duração, como se fosse o próprio leitor a recolher e reunir os dados para melhor os conhecer.

Este entendimento da experiência narrativa da reportagem diz-nos que não basta saber que os acontecimentos se deram. Essa é a responsabilidade da notícia (angellô). O dispositivo de mobilização que nos faz "visitar" os acontecimentos no tempo e no espaço não é uma forma de entretenimento.

É a possibilidade de repassar pelos acontecimentos como se tivéssemos sido nós próprios a presenciá-los. Compreende-se então melhor Heidegger para quem a definição primeira do legein é "expor sem intermediários" ${ }^{4}$, ou seja, como se a coisa mesmo estivesse presente. Um bom relato é o que nos dá a sensação de presenciar o

\footnotetext{
${ }_{64}$ "Se escutarmos de maneira grega uma palavra grega, então seguimos seu legein, o que expõe sem intermediários. O que ela expõe é o que está aí diante de nós. Pela palavra grega verdadeiramente ouvida da maneira grega, estamos imediatamente sem presença da coisa mesma, aí diante de nós, e não primeiro apenas diante de uma simples significação verbal" (Heidegger, s/d).
} 
desenrolar dos acontecimentos como se tivéssemos sido nós a vivê-los na condição de testemunhas.

Regressamos elipticamente ao princípio postulado por John Carey quando sustenta que o testemunho é a condição primeira da reportagem. Não é apenas o testemunho do repórter, mas fundamentalmente conta a possibilidade de, através da narrativa, pôr o leitor/ouvinte/ espectador a "testemunhar". Por isso, na verdade, o desejo que o legein exprime não é o de viver de novo os acontecimentos, mas sim de os presenciar, de os testemunhar. Porquê?

Recorremos agora ao pensamento de Hannah Arendt e à sua teoria do espectador (Arendt, 1971) para postular que o desejo de "estar lá" não traduz o desejo de reviver o acontecimento mas o desejo de regressar ao que aconteceu na condição de espectador. O legein como arkhê do reportar, ou seja, da longa tradição do relato na cultura ocidental, não se realiza no desejo de ver tudo, de testemunhar tudo o que aconteceu. Hannah Arendt acrescenta outra função fundamental ao vasto ser-espectador que a narrativa possibilita. Trata-se da vontade de ajuizar, de criticar ou seja de exercer a faculdade de juízo.

O theathai, o ser-espectador realizado na condição humana, reivindica dos deuses o direito a testemunhar os acontecimentos mas também de os julgar. O "voyeurismo" não mobiliza, nem esgota a condição do ser-espectador. É parte de um processo que conduz à complexa fenomenologia do juízo. Exercer um juízo na condição de espectador é o que o dispositivo da narrativa moderna possibilita, criando condições prévias para compreender que, se o que aconteceu é alvo de polémica, então pede um julgamento. Testemunhar um acontecimento à distância, seguindo de forma ordenada os factos e o fio dos acontecimentos com um posicionamento desinteressado, são fases de um dispositivo que pode operar no sentido do mais justo dos juízos - o juízo isento e imparcial - e colocá-lo ao alcance de qualquer pessoa. A simples narrativa de reportagem é, por isso, 
mesmo um complexo (e também democrático) dispositivo de processamento do real.

Diríamos que muitas das narrativas que conhecemos se desviam brutalmente deste objetivo de operativizar a experiência do juízo, disponibilizando-a à condição do sujeito-espectador. Sendo um dispositivo, visa uma experiência sempre em vias de se realizar nas melhores condições possíveis, mas sem ferir o princípio fundamental que é o relato de um acontecimento que aconteceu mesmo. A existência dos acontecimentos nem sempre é fácil de provar nas condições da palavra e da narrativa.

Por isso a reportagem é uma possibilidade, entre outras, na vasta multiplicidade das narrativas modernas e a experiência da crítica e juízo que disputa o legein e competem com as narrativas de ficção.

De que forma competem as reportagens com as ficções?

A argumentação até agora desenvolvida permite-nos responder de forma mais segura à pergunta de Elisabeth Eide What novels can do, and journalism can not? Podemos depois pensar, com outros argumentos, as condições e a eficácia do recentemente chamado jornalismo literário. O jornalismo e a literatura, sobretudo a partir de Mallarmé, tornaram-se categorias alvo de constantes interpretações analíticas e dualistas no campo das ciências humanas. A priori entende-se que existe uma divisão "natural" que separa o jornalismo da ficção e que é a partir dela, por oposição, que se podem definir as características dominantes de cada uma das categorias.

Ao jornalismo associou-se a noção de facto objetivo e estabeleceu-se, como critério definidor, o compromisso das suas narrativas com a realidade. À literatura ligou-se o conceito de ficção como invenção criativa, explorando a imaginação como forma de arte.

O problema é que a ligação do jornalismo à realidade é uma convenção que procura "naturalizar-se" na cultura. O público para acreditar não pode estar sempre a suspeitar de tudo o que lê. Mas as convenções não obedecem a formas universais. Elas resultam daquilo a 
que Roland Barthes chamou o jogo de poder gerado nas "mitologias", ou seja, toda uma série de casos e estórias que alimentam e sustentam a legitimidade do jornalismo, como é exemplo o caso Watergate que se tornou narrativa recorrente nas escolas de jornalismo.

O problema da objetividade tem tido uma influência nas mudanças de estilos, técnicas e géneros do jornalismo. A necessidade de defender a prova de que os factos relatados aconteceram mesmo leva a que o texto noticioso seja entremeado de contextualizações, quebrando a linearidade simples de uma história; recorra a palavras diretas, eliminando a adjetivação mas também despojando o texto de expressões com uma forte carga emocional e que normalmente funcionam nas ficções como embraiadores decisivos para envolver o leitor. É na reportagem que este dilema mais se coloca. Ao aproximar-se do texto de agência para legitimar a objetividade do relatado, o texto de reportagem afasta-se do seu dispositivo natural que é o envolvimento capaz de "mobilizar" o leitor para o legein. Quando as reportagens se afastam do legein, os acontecimentos que dão a conhecer são normalmente apanhados pelas ficções. Tanto a literatura como o cinema conseguem normalmente "oferecer" ações ao leitor e ao espectador que o jornalista, por dever, não consegue descrever porque não o pode provar. As ficções operam, por isso, nas margens em brancas deixadas pelo jornalismo.

A narrativa ficcional aproveita-se da reportagem nos temas e também na forma realística como "arma" as suas narrativas. São muitas vezes histórias baseadas em factos reais, com pormenores inventados mas que poderiam ter acontecido. Têm um poder invulgar de verosimilhança.

A eficácia do cinema em contar histórias reais é não só muito eficaz a mobilizar o interesse do espectador mas também a baralhar as convenções que artificialmente separam a linha entre o real e a ficção. Por isso, alguns jornalistas não resistem à sedução da literatura, recorrendo às técnicas narrativas literárias para depois publicarem reportagens tão densas e pormenorizadas que rivalizavam com os 
filmes. Houve casos de prémios Pulitzer que, mais tarde, foram desmascarados como reportagens inventadas. ${ }^{65}$

Como é que isto pode acontecer? Por um lado, a convenção naturalizada da objetividade, se não for constantemente redefinida, impõe-se como uma autoridade sobre todos os textos jornalísticos. As pessoas acreditam por tradição num jornal ou num telejornal. Escreveu Nietzsche "as verdades são ilusões que nós esquecemos que o são" (Nietzsche, 1999: 57). Mas, pergunta Cristiane Costa:

\begin{abstract}
"a partir de que momento as categorias literatura e jornalismo são naturalizadas e a fronteira entre os dois campos definida? O fato é que, se as fronteiras entre jornalismo e literatura foram construídas a partir de valores bipolares como realidade e imaginação, objectividade e subjectividade, linguagem utilitária e expressiva, significante e significado ou se fazem parte da essência dos dois géneros, o fato é que elas são visíveis" (Costa, s/d:3).
\end{abstract}

Toda a minha argumentação se desenvolve não no sentido de pensar o que separa as categorias de literatura e jornalismo mas o que as une. O que as une é serem narrativa. Como narrativa são uma forma de estruturação da experiência. Todas as narrativas se estruturam a partir do pedido do legein, ou seja, mobilizam um determinado dispositivo de ampliação e mobilização da experiência natural dos indivíduos, conduzindo-os para uma vasta e ubíqua visão testemunhal dos acontecimentos interessantes ocorridos no mundo. Viagem, teatro e tribunal, ou seja, experiência e juízo são as fases deste dispositivo.

\footnotetext{
${ }^{65} \mathrm{O}$ caso mais clássico e por isso mesmo pioneiro aconteceu no respeitável The Washington Post. Uma jovem colaboradora, Janet Cook, publicou uma emocionante reportagem sobre uma criança de oito anos intitulada "Jimmy's World" viciada em heroína injetada pela própria família. A reportagem, cheia de detalhes, venceu meses depois o prestigiado prémio Pullitzer. Mais tarde, descobriu-se que a repórter inventara a história.
} 
O que separa a reportagem da literatura de ficção é que a reportagem, limitada pelo código ético de servir o facto e a verosimilhança, não consegue, com a mesma liberdade da ficção, recriar a proximidade da ação, a intimidade do acontecimento que levariam a realizar de forma perfeita o legein.

Não é por acaso que a maioria das ficções trabalha a partir de casos reais ou com um solo de verosimilhança muito forte. É difícil que uma testemunha assista de perto, por dentro da mente, ao percurso de um assassino ou de um presidente no momento de uma decisão histórica como facilmente acontece na escrita literária.

Os momentos trágicos normalmente são testemunhados em diferido ou inferidos pela ação policial. A ficção opera nas margens da reportagem mas oferecendo aquilo que mais se deseja que é estar o mais perto possível no momento em que o mais importante de um acontecimento acontece mesmo. Ainda que o faça sem garantias de objetividade a ficção oferece o "como se" com uma força que a reportagem não consegue. A ficção não se oferece ao facto mas oferece-se ao juízo.

Reportagem e ficção competem num mesmo campo de experiência que é o da narrativa e do juízo. Por isso, partilham historicamente as mesmas técnicas narrativas. Para Tom Wolf, precursor do jornalismo literário, o "novo jornalismo" é a narrativa que usa técnicas literárias. O crescente interesse pelo jornalismo literário nos últimos anos não é mais que a velha aspiração de conseguir, numa mesma fórmula narrativa, a fusão que concretize a proximidade entre reportagem e ficção e que guarde o melhor das suas experiências na realização do legein. Trabalho complicado. Como guardar o melhor da estrutura narrativa da ficção, a duração, o detalhe, a descrição intensa do encadeado de ações e dos diálogos, sem pôr em causa o factual?

O fogoso investimento no jornalismo literário tem feito com que muitos trabalhos de reportagem percam a credibilidade factual que é o contrato que liga o leitor ao jornalismo e não sejam mais que 
formas de ficção travestidas. Jacques Rancière, ecoando Lacan, também sustenta que o "real para ser pensado precisa de ser ficcionado" (Rancière, 2009). Penso que se trata de uma interpretação demasiado lata do universo das ficções. Poderíamos começar por dizer que o real, para ser pensado, precisa de ser narrado o que significa, no gesto mais genuíno, ser reportado. Refletir a partir de lógicas dualistas que separam o real da ficção, o jornalismo da literatura, é insistir nas categorias que nos aprisionam na interpretação.

Este ensaio pretendeu demonstrar que a "reportagem" montou um dispositivo tão forte e tão exigente que serve de fundação tanto às narrativas do real como às da ficção. São parte do desejo forte e sempre incompleto de realizar o legein. É verdade que a força da ficção e dos seus modelos, a que nos referimos no início deste texto, prova que os filmes e as novelas conseguem aquilo que a reportagem não alcança porque se constata "que a ficção da era estética definiu modelos de conexão entre apresentação dos factos e formas de inteligibilidade que tornam indefinida a fronteira entre razão dos factos e razão da ficção" (Rancière, 2009: 58).

A inteligibilidade do real gerada a partir das narrativas de ficção é tão forte e dominante na construção simbólica da realidade, que vai arrastando sedutoramente os outros campos narrativos. No jornalismo isso é evidente nas modas do infotainment e do jornalismo literário.

Não respondendo a nada definitivamente, este ensaio deixa uma reflexão para trás e uma provocação para a frente. Porque não inverter a lógica da inteligibilidade dominante e pensar antes o que consegue alcançar a reportagem que os filmes não conseguem?

Se realmente o real, para ser pensado, precisa de ser narrado, trata-se de estudar qual a forma narrativa que melhor preserva a qualidade crítica da experiência: a ética tendencialmente objetiva da reportagem jornalística ou a liberdade sem limites da criatividade ficcional. 


\section{REFERÊNCIAS BIBLIOGRÁFICAS}

ARAÚJO, M. R. (1946). A reportagem como género: género do jornalismo através do constante histórico-literário. Tese de licenciatura em Filologia Românica na Faculdade de Letras da Universidade de Lisboa. Biblioteca da Faculdade de Letras de Lisboa.

ARENDT, H. (1971/1999). A Vida do Espírito, col. "Pensar», Vol. I, Lisboa: Instituto Piaget.

BENJAMIN, W. (1936/1994). "O Narrador: Considerações Sobre a Obra de Nikolai Leskov" in Magia e técnica, arte e política: ensaios sobre literatura e bistória da cultura. São Paulo: Brasiliense, pp. 197-221.

BRETON, A. (1926). "Légitime défense " in Point du jour. Paris : Gallimard, pp. 33-36.

CASTRO, M. A. (2013). "Dialéctica e diálogo: a verdade do humano", in Revista TB, 192, Jan. Mar., Rio de Janeiro, p. 14.

CAREY, J. (1996). The Faber Book of Reportage. London: Paperback.

COSTA, C. (s/d). "Fronteiras Cruzadas - A Ficção no Jornalismo e a Reportagem na Literatura", in Revista Z Cultural, n 5 (http://revistazcultural.pacc.ufrj.br/)

DELEUZE, J. (1986 / 2005). Foucault. Lisboa : Edições 70.

DIDEROT, D. (1766). "Hebdomadaires", in Encyclopédie ou Dictionnaire raisonné des sciences, des arts et des métiers, $1^{\text {re }}$ éd. (www.xn-encyclopdie-ibb.eu/S. html) [11-5-2015]

FOUCAUlT, M. (1975). Em Defesa da Sociedade: Curso no Collége de France. São Paulo: Martins Fontes.

GODINHO, J. (2009). Origens da Reportagem: Imprensa. Lisboa: Livros Horizonte.

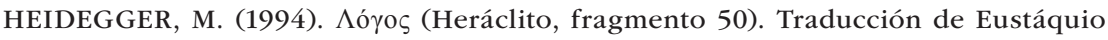
Barjau em Conferencias y artículos. Barcelona: Serbal, pp. 179-199.

HEIDEGGER, M. (s/d). Que é isto - a filosofia? Trad. de Ernildo Stein. http://br.egroups. com/group/acroplis.

MALLARMÉ, S. (1897/ 2011). Crise de Versos. Lisboa: Deriva Editores.

NIETZSCHE, F. (1999). Verdade e Mentir no sentido extra-moral. São Paulo: Nova Cultural.

RANCIÈRE, J. (2009). A partilha do sensível. Estética e Política. São Paulo: Editora 34. 
SILVA, D. (2014). De onde vêm as palavras: origens e curiosidades da língua portuguesa. São Paulo: Léxicon.

STENDHAL (1974). A Cartuxa de Parma. (tradução de Adolfo Casais Monteiro). Porto: Editorial Inova.

VOlTAIRE, F. M. A. (1737). "Conseils à un Journaliste», in CEuvres complètes de Voltaire, éd. Luis Moland. Paris: Garnier, 1877-1885, tome 22. 
A Personagem mediática 
(Página deixada propositadamente em branco.) 


\title{
A PALAVRA EM MOVIMENTO: \\ A AdAPTAÇÃo PARA CINEMA DE "EMBARGO" \\ E DE A JANGADA DE PEDRA \\ DE JOSÉ SARAMAGO
}

\author{
Ana Paula Arnaut \\ Centro de Literatura Portuguesa \\ Universidade de Coimbra
}

A noção mais lata de adaptação tem muito em comum com a teoria da interpretação, pois a adaptação é, em grande medida, a apropriação do significado de um texto prévio. Dudley Andrew, apud BELLO, 2008

Diálogo entre dois ratinhos roendo películas em Hollywood:

- E aí, já roeste aquele filme lá?

- Sim.

- Estava bom?

- Gostei mais do romance.

apud BRITO, s.d. 
Tão antiga quanto as origens do cinema, ou quase tão antiga quanto ela ${ }^{66}$, a questão da adaptação fílmica de obras literárias ${ }^{67}$ traz consigo, inevitável e naturalmente, a discussão da primazia, da qualidade, de uma sobre a outra e, em concomitância, a problemática da traição e/ou da fidelidade relativamente ao texto-fonte. Estes últimos aspetos, por sua vez, prendem-se, em regra, com o que pode ser designado como "redução da articulação com o literário" (Torres, 2000: 58), que aqui entendemos como o jogo diferencial relativo à determinação e avaliação do rigor do pormenor relativamente à descrição-composição-caracterização de ambientes, de personagens e de ações. O que parece ficar esquecido nesta dinâmica relacional, pela maioria dos espectadores e também por alguma crítica académica e jornalística que vê as adaptações como "belated, middlebrow, or culturally inferior" (Naremore apud Hutcheon, 2006: 2) ${ }^{68}$, prende-se, no entanto, com um ponto de não pouca importância, já devidamente assinalado pelo escritor Vergílio Ferreira a propósito da adaptação para cinema do romance Cântico final (1960) ${ }^{69}:$ "o "espírito" do livro" (Ferreira, 1995: 202). Ora, é precisamente nesta linha de manutenção

\footnotetext{
66 "Em 1897, menos de dois anos após a apresentação pública do cinematógrafo dos irmãos Lumière, já George Meliès filmava Fausto e Margarida; um ano depois adaptava A Gata Borralheira e, em 1902, estreava Viagem à Lua, a primeira das adaptações que fez de Júlio Verne" (CARDOSO, 1995: 1148).

${ }^{67}$ Para o estudo da relação inversa, isto é, da novelização (livros publicados a partir de filmes), ver BAETENS \& LITS, 2004 ("Chapitre I: La novellisation: naissance d'un concept", "Chapitre II: Du cinéma au roman", "Chapitre III: Variations transmédiatiques de la novellisation").

${ }^{68}$ Atentemos, ainda, nas palavras de Robert Stam: "A linguagem convencional da crítica sobre as adaptações tem sido, com frequência, profundamente moralista, rica em termos que sugerem que o cinema, de alguma forma, fez um desserviço à literatura. Termos como "infidelidade", "traição", "deformação", "violação", abastardamento", "vulgarização", e "profanação" proliferam no discurso sobre adaptações, cada palavra carregando sua carga específica de ignomínia. "Infidelidade" carrega insinuações de pudor vitoriano; "traição" evoca perfídia ética; "abastardamento" conota ilegitimidade; "deformação" sugere aversão estética e monstruosidade; "violação" lembra violência sexual; "vulgarização" insinua degradação de classe; e "profanação" implica sacrilégio religioso e blasfêmia" (STAM, 2006: 19).

${ }^{69}$ Sobre o percurso estético-literário do romance ao filme realizado por Manuel Guimarães (1975), ver Cardoso, 2000.
} 
de fidelidade ao espírito da obra - e não ao rigor da ilustração das suas passagens - que julgamos ser necessário ler as adaptações de A Jangada de Pedra (realização de George Sluizer, 2002) e, especialmente, do conto "Embargo" (realização de António Ferreira, 2010).

Incluído na coletânea de contos intitulada Objecto Quase, publicada por José Saramago em 1978, mas primeiro dado à estampa em 1973, com o título "O Embargo" ${ }^{\text {, }}$ o texto-fonte do filme ${ }^{71}$ de António Ferreira serviu inicialmente um projeto de uma curta-metragem que, segundo o próprio realizador, "era bastante fiel" ao original. Uma fidelidade que, depreendemos das suas palavras, se diluirá na passagem para a longa-metragem, em que houve a necessidade de "arranjar uma história para a personagem, um objetivo, uma família" (Ferreira, 2010) ${ }^{72}$. Mas, afinal, como afirma, "Quando os realizadores se agarram demasiadamente aos livros dá asneira. A literatura e o cinema são meios completamente diferentes. Ou se adapta ou o filme é chato" (Ferreira, 2010).

Seja como for, acreditamos que, numa primeira leitura, estas adições-alterações podem levar alguns espectadores (eventualmente os menos conhecedores da dinâmica temática saramaguiana) a pensar que a transposição intermediática se consubstancia em traição, em não cumprimento de uma linha de fidelidade relativamente ao texto

\footnotetext{
${ }^{70}$ Publicado pelos Estúdios Cor (Lisboa), com ilustrações de Fernando de Azevedo, integra a série de contos de Natal que, por tradição, a editora dava à estampa. Os dactiloscritos (I e II), com emendas autógrafas (o segundo ainda com correções em relação ao primeiro) estão disponíveis em: http://purl.pt/13868/2/ e http://purl.pt/13869/2/, respetivamente. É possível verificar a existência de pequenas diferenças entre os dactiloscritos, a publicação de 1973 e o texto incluído em Objecto Quase, sendo a mais importante a que ocorre no parágrafo final, de que nos ocuparemos em tempo oportuno.

${ }^{71}$ Estreou no FantasPorto 2010, tendo recebido o prémio Menção Especial do Júri. Produção: Persona non grata pictures. Coprodução: Vaca Films (Espanha), Diler e Associados (Brasil), Sofá Filmes (Portugal). Produtores: Tathiani Sacilotto e António Ferreira. Produtores Associados: Borja Pena, Emma Lustres, Diler Trindade. Elenco: Filipe Costa, Cláudia Carvalho, Pedro Diogo, Fernando Taborda, José Raposo, Miguel Lança, Eloy Monteiro. Argumento: Tiago Sousa. Fotografia: Paulo Castilho. Música Original: Luís Pedro Madeira. Produção Executiva: Tathiani Sacilotto. Financiamento: ICA, IBERMEDIA e Ministério da Cultura.

${ }^{72}$ Ver, também, Andrade, 2010: 14-15.
} 
original ou, numa linha de entendimento mais ampla, relativamente ao espírito da obra do autor. Numa leitura menos preconceituosa, porém sempre tendo em mente que, neste exercício, "a verdade não pode ser mais do que uma cara sobreposta às infinitas máscaras variantes" (Saramago, 1989: 26), o resultado revela-se outro, como verificaremos.

A verdade do conto de José Saramago tem como pano de fundo um espaço não identificado, numa estratégia de teor universalizante retomada, principalmente, nos romances que compõem o segundo ciclo da produção ficcional do autor ${ }^{73}$. Uma estratégia que, neste texto de 1978, também parece passível de ser ilustrada pela redução titular (que deixa de exibir o artigo definido ' $O$ '), facto que contribui para a abrangência da dinâmica transtemporal e, por que não, transespacial.

Como personagens, confirmando a contenção exigida à narrativa breve, contamos apenas com três, ou, talvez(?), quatro, considerando que o carro ganhará vida própria, por ventura disputando o lugar de protagonista que atribuímos ao homem: um garoto, uma mulher e o seu marido, o protagonista(?), um homem, também nunca sujeito a uma individualização antroponímica, que se torna prisioneiro-refém do seu próprio automóvel.

O tempo é o de "Um Natal escuro e frio" (Saramago, 1978: 40), que o leitor em 1973 terá facilmente identificado com o período de crise que então se vivia, num reconhecimento que o correr dos anos tornará mais difícil, eventualmente só se tornando possível ao leitor mais atento à realidade político-social das últimas três décadas do século XX. Referimo-nos à época do embargo petrolífero de 1973 e às consequências daí decorrentes: a redução drástica da produção e exportação de combustível, pela Organização dos Países Exportadores de Petróleo (OPEP), em virtude do apoio norte-americano dado a Israel durante o conflito que, em outubro desse ano, opôs árabes e israelitas (Guerra do Yom Kippur).

\footnotetext{
${ }^{73}$ Ver Arnaut, 2008: 15-51 e Arnaut, 2010.
} 
Não se estranha, por conseguinte, que a temática englobante de "Embargo", numa linha aplicável tanto ao conto quanto ao filme (embora de modo diverso, como veremos), se traduza na coisificação do homem e na (consequente) humanização da máquina, ou, nas palavras de Maria Alzira Seixo, na "escravização e destruição do homem pelo objecto", num cenário que é o do "labirinto da cidade (...) (marca do pesadelo, da viagem circular, da absurda ideologia do final, do concreto terror da coação)" (Seixo, 1979: 78).

Num clima de tensão crescente e numa ambiência não por acaso marcada pela chuva que cai, e que acompanha os momentos angustiantes até ao momento em que o carro morre (recomeçando, também não por acaso, no final) (Saramago, 1978: 49, 50), assistimos, pois, à elevação do objeto à categoria de pessoa com vontade própria, mas não sem antes passar por um estado intermédio de zoomorfização. Este, aliado a um processo de desumanização, curiosamente, ou talvez não, também se aplica ao homem:

O tempo arrefecera muito. Mas ali, dentro do automóvel, de jornal aberto sobre o volante, fumando enquanto esperava, havia um calor agradável, como o dos lençóis. Fez mover os músculos das costas, com uma torção de gato voluptuoso, ao lembrar-se da mulher ainda enroscada na cama àquela hora, e recostou-se melhor no assento. $\mathrm{O}$ jornal não prometia nada de bom. O embargo mantinha-se (Saramago, 1978: 40) (itálicos nossos).

Sentia fome. Urinara outra vez, humilhado de mais para se envergonhar. E delirava um pouco: humilhado, himolhado. Ia declinando sucessivamente, alterando as consoantes e as vogais, num exercício inconsciente e obsessivo que o defendia da realidade. Não parava porque não sabia para que iria parar. Mas, de madrugada, por duas vezes, encostou o carro 
à berma e tentou sair devagarinho, como se entretanto ele e o carro tivessem chegado a um acordo de pazes e fosse a altura de tirar a prova da boa-fé de cada um. Por duas vezes falou baixinho quando o assento o segurou, por duas vezes tentou convencer o automóvel a deixá-lo sair a bem, por duas vezes no descampado nocturno e gelado, onde a chuva não parava, explodiu em gritos, em uivos, em lágrimas, em desespero cego. As feridas da cabeça e da mão voltaram a sangrar. E ele, soluçando, sufocado, gemendo como um animal aterrorizado, continuou a conduzir o carro. A deixar-se conduzir (Saramago, 1978: 49) (itálicos nossos).

Chamando a atenção para o facto de a primeira citação, relativa a um momento anterior à constatação do pleno domínio do carro sobre o homem, parecer ilustrar a dependência afetiva deste sobre aquele, remetendo-nos para uma ambiência de voluptuosidade semelhante ao ato sexual (e que parece corresponder ao ponto de viragem em que a máquina ganha o poder do homem), não podemos deixar de salientar que a orquestração da narrativa é pautada pelo absurdo, reconhecido pela personagem (Saramago, 1978: 45) e assumido, pelo próprio autor, na sua relação (quase) sinonímica com o fantástico, como alguma coisa "que ainda não aconteceu mas, talvez, seja acontecível" (apud Cuadrado, 2007: 44).

Deste modo, se, num primeiro momento, pode passar despercebida a menção ao facto de que as gotículas que cobrem a viatura a fazem parecer-se com um corpo vivo que transpira (Saramago, 1978: 38), num segundo momento a sistemática sucessão de elementos que continuam a sua personificação não deixa margem para quaisquer dúvidas. Assim sabemos, por exemplo, de um carro que arfa, profunda e impacientemente, que raspa "o asfalto como um animal de cascos", que se torna "vibrante e tenso" (Saramago, 1978: 39), respondendo "aos seus movimentos como se fosse um prolongamento mecânico 
do seu próprio corpo" (Saramago, 1978: 41)74, até que, finalmente, começa a assumir um controlo que não the permite apenas obliquar "para a esquerda, por si mesmo", indo "parar, suavemente, como se suspirasse, no fim" de uma fila para se reabastecer de gasolina (Saramago, 1978: 42). Além disso, o controlo que progressivamente ganha não só lhe permite impedir o condutor de sair do habitáculo, como o vai tornando completamente autónomo em relação às suas manobras de condução (Saramago, 1978: 43, 49). Uma autonomia que se mantém pelo menos até ao momento em que, depois de uma viagem sem rumo por dentro da noite, a falta de gasolina o obriga a parar e, na sequência, a libertar o homem.

Atentemos, pois, no parágrafo final da versão de $1978^{75}$, registando, entre parêntesis retos, as omissões que consideramos mais significativas relativamente aos dactiloscritos e ao texto publicado em 1973, importantes não só pelos sentidos que oferecem, ou que elimina[ra] $\mathrm{m}$, mas, essencialmente, pelos laços relacionais que permitem com a adaptação de António Ferreira:

\begin{abstract}
A testa cobriu-se-lhe de suor frio. Uma náusea agarrou nele e sacudiu-o dos pés à cabeça, um véu cobriu-lhe por três vezes os olhos. Às apalpadelas, abriu a porta para se libertar da sufocação que aí vinha, e nesse movimento, porque fosse morrer ou porque o motor morrera ${ }^{76}$, o corpo pendeu para o lado esquerdo e escorregou do carro. Escorregou um pouco
\end{abstract}

\footnotetext{
${ }^{74}$ Vejam-se ainda os seguintes exemplos: "O ponteiro indicava precisamente meio depósito. Parou num sinal vermelho, sentindo o carro vibrante e tenso nas suas mãos. Curioso. Nunca dera por esta espécie de frémito animal que percorria em ondas as chapas da carroçaria e lhe fazia estremecer o ventre", "Como um perdigueiro que acode ao cheiro, o carro insinuou-se por entre o trânsito, voltou duas esquinas e foi ocupar lugar na fila que esperava. Boa lembrança" (SARAMAGO, 1978, 39, 40, respetivamente).

${ }^{75}$ Ver supra, nota 77.

${ }^{76}$ Emenda autógrafa ("o motor morrera"), dactiloscrito I, mantida no dactiloscrito II e na edição Estúdios Cor.
} 
mais, [agora morto $\left.{ }^{77}\right]\left[\mathrm{de} \mathrm{vez},{ }^{78}\right]$ e ficou deitado sobre as pedras. [Como um rato. ${ }^{79}$ ] [mal parido. ${ }^{80}$ ] A chuva recomeçara a cair (Saramago, 1978: 50).

Vejamos, então, numa linha de leitura assumidamente subjetiva e que sabemos não ser consensual: parece-nos que o texto da versão mais recente (Objecto Quase) aponta para um final aberto, não nos parecendo linear que o homem morra, bastando, para tal conclusão, atentar na disjuntiva "ou porque fosse morrer ou porque o motor morrera”. Além disso, não só a frase que acabamos de registar pode apenas significar a impressão de morte, e não a morte efetiva, como a chuva que no final recomeça a cair (depois de ter parado "de repente”, em coincidência com o acabar da gasolina, Saramago, 1978: 49) pode ser lida no âmbito de uma dimensão purificadora inerente a uma leitura simbólica desse elemento (Chevalier e Gheerbrant, 1982: 765-767). De acordo com o exposto, e tendo em mente a dimensão profundamente ideológica da obra saramaguiana e, naturalmente, as inevitáveis relações com o contexto histórico-social em que se enraíza, podemos admitir que, em relação a 1973 (tempo-espaço, ainda, de regime estado novista, tempo-espaço não ainda de um regime democrático tornado possível pela Revolução de Abril), José Saramago evidencia, no presente de 1978, uma tendência para ver a Humanidade de forma não inteiramente sombria. Afinal, ao contrário do que sucede com o homem que, quase no início do conto (e do domínio do carro), maneja, sem sucesso, "a alavanca das velocidades para meter a marcha atrás" (Saramago, 1978: 41), talvez, afinal, ainda haja hipótese de reverter a situação de dependência em que os sucessivos avanços tecnológicos nos colocaram.

\footnotetext{
${ }^{77}$ Dactiloscritos I e II e edição Estúdios Cor.

${ }^{78}$ Emenda autógrafa, dactiloscrito I, mantida no dactiloscrito II e na edição Estúdios Cor.

${ }^{79}$ Dactiloscritos I e II e edição Estúdios Cor.

${ }^{80}$ Edição Estúdios Cor.
} 
Sublinhe-se que a tonalidade do final fechado da versão dos Estúdios Cor se torna mais sinistra porque, à constatação fria do destino do homem, "agora morto de vez", se alia a comparação "Como um rato mal parido", numa imagem cuja força se intensifica não só pela escolha de um animal aceite, em regra, como repugnante e repulsivo mas, também, pela sua recorrência ao longo do conto. Em primeiro lugar, quando o homem sai de casa e vê "um grande rato morto" "Na berma do passeio" e em cima do qual um garoto cospe, "como the tinham ensinado e sempre via fazer" (Saramago, 1978: 38). Em segundo lugar, quando, já, e ainda, preso no carro, o homem regressa a casa para falar com a mulher e cabe a esta observar "um rato morto na berma do passeio", "mole, de pêlo arripiado" (Saramago, 1978: 47). Em terceiro lugar, na sequência do quadro anterior, quando a mulher regressa à rua e verifica que "o automóvel já desaparecera e o rato escorregara da berma do passeio, enfim, e rolava na rua inclinada, arrastado pela água que corria dos algerozes" (Saramago, 1978: 48).

Antecipando, mais uma vez, estratégias que serão postas em prática em romances posteriores, "Embargo" pode, deste modo, ser encarado como um aviso à navegação que, apesar de partir da exposição-denúncia de uma cena social e política regida por ditames consumistas e capitalistas, inscreve, contudo, a crença, a esperança, na redenção da Humanidade (Arnaut, 2014: 42-43). $\mathrm{Ou}$, em termos mais concretos, a esperança na possibilidade de o Homem se libertar da miséria da sua condição materialista uma missão que, como sugerimos, parece impraticável nos dactiloscritos e na sua versão final de 1973, mas que não parece impossível deduzir a partir do texto de 1978 e da adaptação de António Ferreira.

Assim, mantendo embora as "ideias centrais do conto. A dependência que temos das coisas" (Ferreira, 2010), a variação, a diferença relativamente ao texto-fonte decorre de processos de adição (Brito, 
s.d.: 7) ${ }^{81}$ que, em primeiro lugar, dizem respeito ao recurso a um maior número de personagens, agora quase sempre identificadas pelo seu nome próprio, como sucede com Nuno, o (co)protagonista (lembrando a partilha de primeiro plano com o carro), com sua mulher, Margarida, com Sara, a filha do casal ou, entre outras, com Sérgio, que, com o primeiro, trabalha numa roulotte de bifanas. Em segundo lugar, a diferença é instaurada pela orquestração de um enredo mais completo e complexo, que não só ganha em coesão e em coerência semânticas (apesar da manutenção das já referidas afinidades com o fantástico), como também adquire dimensões cómicas desde logo facultadas pela cena inicial e pela correspondente banda sonora original, da autoria de Luís Pedro Madeira ${ }^{82}$. Esta, de acordo com alguma crítica ${ }^{83}$ com a qual não concordamos inteiramente, acaba por cair no cliché ao ecoar sonoridades já conhecidas de filmes de Quentin Tarantino:

"Embargo", o filme, começa com uma sequência tintada de
cores gastas pelo tempo, num lugar e numa época indefi-
nidos, num mundo esvaziado de pessoas e com as bombas

${ }^{81}$ Partindo do que considera serem as "constatações mais pertinentes" de Francis Vannoye sobre a "passagem da estrutura literária para a cinematográfica", João Brito aponta duas "básicas operações": "redução e adição". A estas acrescenta "duas outras por ele não contempladas, e no nosso entender igualmente assíduas, a saber, o deslocamento e a transformação, esta última podendo se subdividir em simplificação, ampliação. Com efeito, de um modo geral, há coisas que estavam no romance e não estão mais no filme (redução), há coisas que estão no filme e que não estavam no romance (adição), e finalmente, há coisas que estão nos dois, porém, de modo diferente (deslocamento, transformação). O que complica, porém, a relativa simplicidade do esquema é que essas reduções, adições e transformações acontecem em vários níveis que precisam ser distinguidos" e que restringe "a três elementos: enredo, personagens e linguagem" (BRITO, s.d.: 6, cf. 10 para um "esquema mínimo do processo adaptativo").

${ }^{82}$ Ver/ouvir em https://www.facebook.com/embargo.movie (consultado em 5 de fevereiro de 2015).

${ }^{83} \mathrm{Ver}$ crítica ao filme por Ante-Cinema em http://www.ante-cinema.com/critica-\%C2\%ABembargo\%C2\%BB-um-filme-embargado-na-longa-duracao/ (consultado em 21 de janeiro de 2015). 
de gasolina esgotadas - "uma espécie de Mad Max à portuguesa", diz o autor. O guarda-roupa das personagens e um velho Opel Kadett transportam-nos para a década de 70, mas o aparecimento de um computador, um "scanner" e um telemóvel, do mesmo modo que a associação da pop anos 60 com a música tecno, vêm baralhar a datação. "O filme, como não é passado nem presente, só pode ser futuro", o que torna a mensagem ainda mais inquietante. Com esta indefinição, o realizador quis também evitar o risco de ver os espectadores a procurarem a verosimilhança dos adereços, lançando-os antes para "um mundo suspenso de um embargo" em que um homem (Filipe Costa, actor e músico) se vê de um momento para o outro literalmente presa do seu carro e da voracidade deste pela gasolina que cada vez é mais escassa (Andrade, 2010: 15).

"[M]undo suspenso de um embargo", ou não, baralhado pela datação, ou não, a verdade é que António Ferreira nos oferece uma realidade preocupante que é, com efeito, a nossa, e que é, também, sem sombra de dúvida, direta ou indiretamente, a dos universos saramaguianos.

Não nos referimos apenas às assimetrias sociais sub-repticiamente presentes, por exemplo, em termos englobantes, no contraste entre as condições da vida familiar de Nuno e a ambiência em que se movimentam os empresários a quem tenta vender uma máquina de digitalizar pés (permitindo fazer sapatos de exata medida), invenção que o faria ascender financeiramente e, por consequência, a abandonar o trabalho na roulotte de bifanas. A mesma roulotte onde, como já dissemos, também trabalha Sérgio que, não por acaso, convocando mais uma vez a dinâmica ideológica de José Saramago, é focado (em plano de semi-conjunto) a ler um livro que, como verificaremos (primeiro recorrendo ao insert e, depois, a vários close 
$\left.u p s^{84}\right)$, se intitula Teoria das Classes Sociais (de Nicos Poulantzas). Referimo-nos, ainda, e em particular, agora numa linha estreitamente ligada ao conto, ao controlo do humano pela máquina e à consequente inversão de papéis. Em cenas cujo suspense aumenta na medida proporcional à intensidade ou à profundidade da banda sonora, a autonomização do carro em relação à personagem ganha contornos mais relevantes pelo facto de, em várias ocasiões, a dinâmica de vontade própria da viatura se consubstanciar na capacidade de ligar o rádio. Não por mera coincidência, segundo julgamos, e sublinhando as potencialidades de ilustração e de interpretação das opções sonoras na sua conjugação com a imagem (HUTCHEON, 2006: 70), a música escolhida é "Tu piangi, o Filli mia”, da autoria de Carlo Gesualdo:

Tu piangi, o Filli mia,

E pensi estinguer quell'ardente fiamma

Che sì dolce m'infiamma.

Ahi, che sì picciol pianto fa che il core

Tanto più avvampi di vivace ardore ${ }^{85}$.

A composição musical invoca uma das mais belas e trágicas histórias de amor da antiguidade: o suicídio de Fílis, desesperada pelo abandono de Demofonte, que é, por piedade dos deuses, transformada numa amendoeira que só floresce quando o marido, finalmente

84 “[O] plano de conjunto (...) cobre todo o cenário construído e o semi-conjunto (...) cobre apenas parte do cenário [o interior da roulotte]. No que respeita às personagens, o plano médio enquadra-as em pé, o plano americano a meia-perna, o plano aproximado à altura da cintura ou do peito, o grande plano à altura do pescoço. $O$ plano de pormenor isola uma parte do rosto (olhos, boca...), enquanto o insert designa o plano de pormenor de um objecto (o inglês faz uma distinção entre close-up para os rostos e insert para os objectos)" (Journot, 2009: 56, "Escala de planos").

${ }^{85}$ Publicada em Nápoles, em 1611 (Madrigali libro sesto). "Tu choras, ó Filli minha, / E pensas extinguir aquela ardente chama / Que tão doce me inflama. / Ah, que tão breve choro faz que o coração / Tanto mais soçobre de vivo ardor" (tradução de Rita Marnoto). 
regressado ao reino da Trácia, a ela se abraça (Grimal, 2004: 171172) ${ }^{86}$. Analisando as três ocorrências da reapropriação do madrigal do compositor italiano, julgamos poder afirmar que as duas primeiras, antes do efetivo aprisionamento de Nuno (que coincide com a terceira), podem corresponder a um subtil e irónico indício que antecipa a ideia de que o abraço a vir não só não dará frutos como será, pelo contrário, quase fatal.

Numa linha extensionalmente paródica, mas tendo presente a dimensão trágica que assiste ao hipotexto, parece, pois, poder convocar-se o anúncio do irremediável e triste fim dos que, no caso, amam desmesuradamente alguma coisa: a máquina (e é necessário não esquecer que o obsessivo fascínio pela sua invenção leva Nuno, num primeiro momento, a descurar os afetos familiares). A paródia - isto é, a imitação com distanciamento crítico (Hutcheon, 1989: 17) - consubstancia-se, justamente, na ideia de que da relação máquina-Nuno/Homem nada de bom advirá, sempre se inscrevendo sentidos que apontam para os resultados negativos da dependência (do amor?).

O que também está em jogo com o uso de "Tu piangi, o Filli mia" é a possibilidade de confirmarmos, com Christian Metz, que o cinema "tells us continuous stories; it 'says' things that could be conveyed also in the language of words; yet it says them differently" (apud Hutcheon, 2006: 3). De igual modo, Virginia Woolf, apesar de deplorar a simplificação da obra de arte literária na transposição para o novo meio, classificando o filme como "parasite" e a literatura como "its 'prey' and 'victim'”, não deixa de aceitar, como refere Linda Hutcheon, "that film had the potencial to develop its own independente idiom: 'cinema has within its grasp innumerable symbols for emotions that have so far failed to find expression' in words" (apud Hutcheon, 2006:3). E assim, numa máscara visual da

\footnotetext{
${ }^{86}$ Como (quase) sempre sucede na mitologia, há várias versões para a história de Fílis: Demofonte pode ser substituído pelo irmão, Acamante, ou, entre outras diferenças, o reverdescimento da amendoeira resulta de um beijo e não de um abraço.
} 
palavra, assistimos, pela imagem, à progressão da expressão facial de Nuno, da perplexidade ao que vemos como temor, dele e, por sugestão, nossa, também.

Transformados em desespero na medida proporcional ao domínio exercido pelo carro, e talvez numa derradeira tentativa de retomar o controlo, os sentimentos exacerbados levam Nuno a tentar o suicídio, impedido (interrompido?) pela falta de gasolina e pela consequente morte do carcereiro. Lembrando as considerações feitas sobre os finais dos dactilostritos, da edição Estúdios Cor e do conto de 1978, parece-nos que os sentidos implícitos na reta final do filme vão, portanto, ao encontro da possibilidade de verificarmos uma convergência com a proposta de leitura que fizemos do último texto, no qual se baseia o argumento do filme de António Ferreira. Assim, a inscrição de uma linha de esperança na humanização e na redenção do Homem decorre, cremos, do facto de, assumidamente, se mostrar a libertação do (co)protagonista não apenas em relação à máquina-carro mas também no que respeita à ligação (obsessão?) com a máquina de digitalizar pés.

A relativização do valor deste aparelho, a favor de valores familiares adormecidos-interrompidos e a que urge regressar, resulta na decisão de o trocar por um meio de deslocação para casa, uma das trotinetes de um dos miúdos que já conhecíamos das cenas de abertura, em detrimento da proposta-negócio inicial em que um coelho, encontrado após o desencarceramento, seria a moeda de troca.

O diálogo estabelecido entre adulto e crianças por ocasião das negociações referidas é também elucidativo da interpretação que fazemos, na medida em que o miúdo que encabeça o grupo, reconhecendo o valor aparente da peça, claramente afirma a injustiça de trocar o digitalizador apenas por uma trotinete e não por duas. Afinal, a geração dos adultos a ser parece ter consciência de valores fundamentais para a boa organização social e humana. Talvez venham 
a perder a inocência, não sabemos, mas talvez se mantenham genuínos e capazes de compreender as necessidades do outro.

Tal como sucede na constelação ficcional de José Saramago, indo ao encontro do espírito que lhe preside, a mensagem que fica suspensa no além texto, no além filme, é, afinal, a de uma hipótese de uma sociedade mais justa e, por isso, mais fraterna. Assim, ilustrando a retomada de consciência da importância das relações humanas, talvez não seja coincidência que o rato que pontualmente marca algumas cenas da(s) narrativa(s) dê agora lugar ao coelho que, de acordo com promessa feita, substituirá o homónimo peluche decapitado de Sara. Além disso, e ao contrário do rato, elemento de destruição e de morte, o coelho (tal como a lebre) é símbolo de renovação, de renascimento, de fim de um ciclo e de início de um outro (Chevalier e Gheerbrant, 1982: 904, 572-573).

Amplificando, ignorando, subvertendo ou transformando a "densa rede informacional", a "série de pistas verbais" que participam no "texto original" (Stam, 2006: 50), António Ferreira viu no conto "Embargo", "uma expressão situada, produzida em um meio e em um contexto histórico e social", transformando-a "em outra expressão, igualmente situada, produzida em um contexto diferente e transmitida em um meio diferente" (STAM, 2006: 50). O texto-fonte, portanto,

is not something to be reproduced, but rather something to be interpreted and recreated, often in a new medium. It is what some theorists calls a reservoir of instructions, diegetic, narrative, and axiological, that the adapter can use or ignore (...), for the adapter ${ }^{87}$ is an interpreter before becoming a creator (Hutcheon, 2006: 84).

\footnotetext{
${ }^{87}$ Tenhamos em mente que "Films are like operas in that there are many and varied artists involved in the complex process of their creation. Nevertheless, it is evident from both studio press releases and critical response that the director is ultimately held responsible for the overall vision and therefore for the adaptation" (HUTCHEON, 2006: 85).
} 
Não parece simples de aceitar, porém, a ideia de que a transcodificação levada a cabo não resulta necessariamente, repetimos, numa desobediência ao espírito do livro, em particular, ou da obra, em geral. A prová-lo, algumas das críticas também feitas à adaptação para cinema de um outro texto de José Saramago: A Jangada de Pedra, com roteiro da responsabilidade de George Sluizer e Yvette Biro.

Estreado em 2002 com o mesmo título, numa coprodução holandesa, portuguesa e espanhola, o filme do diretor e produtor cinematográfico holandês é assim comentado por Eurico de Barros,

George Sluizer não quis fazer um filme de efeitos especiais espectaculares, à maneira americana, mas essa intenção não foi suficiente para transformar "A Jangada de Pedra" num bom, discreto e sugestivo filme europeu. Esta adaptação do livro do Prémio Nobel José Saramago resulta apenas em mais um "europudim» tépido e incaracterístico, onde o tédio que rapidamente se instala na narrativa alastra às interpretações dos actores, que Sluizer não soube (ou não pretendeu) dirigir. E o filme vai-se afundando mais devagar do que demora à Península Ibérica a chegar a meio do Atlântico (BARROS, s.d.).

Para João Lopes, por seu turno,

Ficou por fazer um grande filme - eis o que apetece dizer face aos resultados algo assépticos desta "transcrição" cinematográfica do romance homónimo de José Saramago. E escrevo assim mesmo, "transcrição" (com aspas), porque parecer ter presidido ao projecto a ilusão (terrível no plano da linguagem cinematográfica) de que a dimensão mágica de "A Jangada de Pedra" - a parábola fantástica da Península 
Ibérica que se desprende do continente e vai vogando pelo mar fora... - seria passível de ser «ilustrada» através de um tom banalmente descritivo, aqui e ali exibindo alguns efeitos especiais (tecnicamente muito limitados, importa dizê-lo). Infelizmente, nenhuma emoção passa, a não ser a sensação penosa de que o filme nunca consegue apropriar-se de qualquer dimensão que não seja a de um «naturalismo» incipiente, aqui e ali tentando fingir algum arrojo espectacular. Os actores, ainda que esforçados, pouco podem fazer, até porque não se sente qualquer trabalho de direcção que consiga aliar de forma inventiva as suas diferenças de origem e sensibilidade (LOPES, s.d., destacados do autor).

Apesar de aceitarmos as perspetivas dos profissionais da área que, aliás, incidem sobre questões técnicas (como a pobreza dos efeitos especiais), julgamos ser necessário relativizar algumas das considerações feitas. Fazemo-lo, naturalmente, de um ponto de vista (quase) leigo que, em todo o caso, merece ser considerado, tendo em mente, mais uma vez, a dinâmica de manutenção do espírito da obra. Deixamos de lado, portanto, as mais polémicas discussões sobre o modo como se encena a fantástica separação da Península Ibérica da velha Europa (ou outros efeitos suscetíveis de repreensão especializada, como a pedra lançada ao mar por Joaquim Sassa), ou, ainda, os aspetos relacionados com o casting (que, por vezes, nesta ou em outras situações-adaptações pode colidir com a imagem mental que a leitura do texto original nos sugere). Não podemos é deixar sem comentário a assunção, de João Lopes, de que "nenhuma emoção passa".

Pelo contrário, não só passam as emoções das personagens, envolvidas em viagens de auto e de heteroconhecimento, como, além disso, ressaltam (em alegoria) as emoções do próprio autor sobre a adesão de Portugal e de Espanha à então Comunidade Económica 
Europeia $^{88}$. Preso nas malhas da ficção que tece, imagina-se transportado (transportando-nos) "na delirante jangada de pedra em que transformara a Península Ibérica, flutuando sobre o mar atlântico, a caminho do Sul e da Utopia" (Saramago, 1989a: 32). Para Saramago, aduza-se,

A peculiaridade da alegoria era transparente: embora prolongando algumas semelhanças com o mais comum dos emigrantes que parte para outras terras a buscar a vida, prevalecia, neste caso, uma definitiva e substancial diferença, a de viajarem também comigo, na migração inaudita, o meu próprio país, todo ele, e, sem que aos espanhóis tivesse pedido a devida licença, portanto sem autorização nem procuração, a Espanha. Ora, embalado nestas minhas imaginações, notava eu que não tinha parte nelas qualquer sentimento de pesar, de tristeza, de aflição mais ou menos pânica, ou, para tudo dizer na inevitável [palavra] portuguesa, saudade. Compreender-se-á já porquê. É certo que, pelos vistos irremediavelmente, me ia afastando da Europa, mas os tecidos vitais da barca imensa que me levava continuavam a alimentar as raízes da minha identidade própria e da minha pertença colectiva: logo, não encontrava causa para chorar um bem perdido, se realmente

\footnotetext{
${ }^{88}$ Os "actos relativos à adesão de Espanha e de Portugal" são assinados a 12 de junho de 1985 e o alargamento da CEE "para 12 Estados-membros" é efetivado a 1 de janeiro de 1986 (SILVA, 2010: 349), ano de publicação do romance. Sobre o sonho de uma união ibérica, ver Gómez Aguilera, 2010: 419; Arnaut, 2008: 38-39. Apesar de o romance simbolicamente defender uma união ibérica, parece-nos que as ancestrais desconfianças (pequenas ou grandes não interessa agora) entre Portugal e Espanha não escapam também ao olhar desassossegado e devastador de José Saramago. Deste modo, quando o narrador refere a "iniciativa do governo espanhol", conducente ao estabelecimento de "contactos entre os dois países peninsulares para a definição de uma política concertada tendente a tirar o melhor partido possível da nova situação", não deixa de aduzir que "em Madrid desconfia-se que o governo português irá para essas negociações com uma reserva mental, qual seja a de pretender, futuramente, extrair benefícios particulares da maior proximidade em que se achará das costas canadianas ou norte-americanas, depende" (Saramago, 1986: 283).
} 
podia ser assim designado o que antes ganho não fora, mesmo tendo tão pouco de bem (SARAMAGO, 1989a: 32).

O posicionamento emotivo que o autor assume nas citações acima transcritas prolonga-se, então, no modo como se urde a narrativa e, por sua vez, encontra a sua tradução, sem traições semânticas, no filme de Sluizer ${ }^{89}$. Em um e em outro texto, diversamente como não podia deixar de ser, a viagem da Península Ibérica tornada jangada de pedra cumpre a função de duplicar o 'não' à adesão dos dois países à CEE/EU. Em substituição do protetorado europeu, Saramago deixa claro que as parcerias necessárias (da economia à política e à cultura) devem ser procuradas em sociedades (em povos), com as quais temos relações ancestrais. E, por isso, a jangada parará, simbolicamente, entre os continentes africano e sul-americano, num tempo que é o de uma gravidez (também simbolicamente) coletiva, como se, dessa forma, se deixasse uma nota de (utópica) esperança num novo destino com uma nova geração e num futuro bem longe da "Mãe amorosa, a Europa" (Saramago, 1986: 33).

Mas o romance, e o filme com ele, não vivem apenas da inscrição, pela palavra e/ou pela imagem, de linhas críticas tecidas em torno da União Europeia e de um extremado, e por vezes hipócrita, desejo de unionismo, como sucede, por exemplo, com a reunião dos países membros da CEE (breve mas incisivamente introduzida no filme por ocasião da chegada ao Hotel Borges, em Lisboa, de Joaquim, José e Pedro), durante a qual é emitida a "declaração solene, nos termos da

\footnotetext{
${ }^{89}$ Não consideramos relevantes, para o efeito, as alterações de local/país relativas à origem das personagens e aos enigmas que protagonizam: Joana Carda traça o risco no chão de Alcácer do Sal e não de Ereira, José Anaiço vive em Zahinas (Estremadura) e não numa aldeia do Ribatejo, Pedro Orce é de Venta Micena e não de Orce, Joaquim Sassa lança a pedra na praia das Maçãs e não numa praia do norte de Portugal, "talvez Afife", e Maria Guavaira desmancha o seu pé-de-meia em Mere (Astúrias) e não na Galiza (Saramago, 1986: 145, 49, 51, 50, 182). Quanto ao local em que pela primeira vez aparece o cão (Ardent, mais tarde chamado Fiel), o filme menciona Irati (Navarra) enquanto o romance, de modo mais vago, refere os Montes Alberes (também em Navarra) (Saramago, 1986: 19).
} 
qual ficava entendido que o deslocamento dos países ibéricos para ocidente não poria em causa os acordos em vigor" (Saramago, 1986: 44). Não fica por escrever, e por mostrar, no entanto, a não unanimidade da deliberação e o "certo desprendimento" de "alguns países membros" que foram "ao ponto de insinuar que se a Península Ibérica se queria ir embora, então que fosse, o erro foi tê-la deixado entrar" (Saramago, 1986: 44). Não por acaso, anteriormente, o filme já havia ironicamente inscrito a ideia de que os franceses preferiam que a "falha" estivesse do lado dos espanhóis, resposta dada pela $\mathrm{Sr}^{\mathrm{a}}$ Enriquez, por ocasião do início da tentativa de reparação da fenda. No romance, porém, em trecho longo, lemos que a fenda é "ab-so-lu-ta-men-te espanhola, ou, para falar com precisão geográfica e nacionalista, navarresa" (Saramago, 1986: 23). Salvaguardadas as devidas distâncias semânticas, julgamos que o efeito obtido é o mesmo: a assunção-inscrição da diferença e a vontade de separação do resto da Europa, diversa, como acima sugerimos, "das realidades ibéricas" (Saramago, 1986: 164). O trecho, que o filme parece aglutinar na cena da "declaração solene", é elucidativo:

Uma ação de contrafogo decidida pelos governos europeus consistiu em organizar debates e mesas-redondas na televisão, com a principal participação de pessoas que tinham fugido da península quando a ruptura se consumou e tornou irreversível, não aquelas que lá tinham estado como turistas e que, coitadas, não tinham ganho para o susto, mas os naturais propriamente ditos, aqueles que, apesar dos apertados laços da tradição e da cultura, da propriedade e do poder, tinham virado as costas ao desvario geológico e escolhido a estabilidade física do continente. Essas pessoas traçaram o negro quadro das realidades ibéricas, deram conselhos, com muita caridade e conhecimento de causa, aos irrequietos que imprudentemente estavam a pôr em perigo a identidade europeia, e concluíram a sua intervenção no debate com uma frase definitiva, olhos 
nos olhos do espectador, Faça como eu, escolha a Europa (Saramago, 1986: 164) ${ }^{90}$.

Na sequência das emotividades tantas vezes anunciadas publicamente por José Saramago, do que se trata, também, é de expor, com a devida dose de ironia, a falta de objetividade da Imprensa, denunciar a cobardice política e, como não podia deixar de acontecer, a prepotência dos Estados Unidos da América do Norte que, numa estratégia enunciativa que visa duplicar os jogos de poder que protagonizam, "assim por extensão inteira deverão ser sempre nomeados" (Saramago, 1986: 213). É certo que não encontramos no filme de Sluizer a variedade de comentários irónicos oferecidos pelo verbo de Saramago $^{91}$, facto que pode levar alguma crítica a apontar

\footnotetext{
${ }^{90}$ Num outro exemplo, ilustrativo tanto do afastamento físico que se vai acentuando quanto do afastamento identitário: "Milhares e milhares foram parar a Marrocos, fugidos quer do Algarve quer da costa espanhola, estes os que estavam para baixo do cabo de Palos, quem estivesse daí para cima preferia ser levado diretamente para a Europa, podendo ser, perguntavam assim, Quanto quer para me levar à Europa" (Saramago, 1986: 42).

${ }^{91}$ Ver Saramago, 1986: 167 (sobre a inusitada "prudência da Casa Branca, em geral tão pronta a intervir nos negócios do mundo), 170 e 272 (a propósito do "reconhecimento" do "espírito humanitário" e do "realismo político" dos EUA, "graças aos quais se tem mantido a níveis razoáveis o abastecimento de carburantes e também de produtos alimentares", muito provavelmente porque uma das hipóteses-expectativas era a de que a Península pararia junto da costa americana, o que permitiria a integração territorial, ilação que pode igualmente ser retirada do anúncio feito pelo presidente de que "os países que aí vinham podiam contar com o apoio e a solidariedade moral e material da nação norte-americana), 213-214 (relativa ao não agrado da "fórmula do governo nacional", à disposição para "evacuar toda a população dos Açores (...)" e ao "sonho secreto do Departamento de Estado e do Pentágono" de que, numa outra hipótese-expectativa, "as ilhas detivessem, mesmo que com alguns estragos, a península, que assim ficaria fixada a meio do Atlântico para benefício da paz no mundo, da civilização ocidental e de óbvias conveniências estratégicas"), 298-299 (acerca de jogos políticos e zonas de influência), 321-322 (a respeito da não demissão "das suas responsabilidades para com a civilização, a liberdade e a paz, mas que os povos peninsulares não podiam contar, agora que penetravam em áreas conflituais de influência (...), com uma ajuda igual àquela que estava à sua espera quando parecia que o seu futuro se tornaria indissociável da nação americana"). Ver, ainda, Saramago, 1986: 139 (para a crítica à sapiência americana) ou 281 (para a "solene garantia de que o tradicional espírito de boa vizinhança entre os Estados Unidos e o Canadá não será afetado por qualquer circunstância", isto é, pela deslocação da Península Ibérica).
} 
um certo efeito de redução (Brito, s.d.: 72, Hutcheon, 2006: 70). Não é menos certo, no entanto, que, na tradução que o filme também é, a ideia englobante da reclamada supremacia norte-americana se encontra ilustrada no protagonismo concedido aos ianques (ausentes no texto-fonte) na tentativa inicial de reparar a falha que, de forma irremediável, nos separaria de França e $\mathrm{C}^{\text {ia }}$. Apesar da criticada deficiência técnica dos efeitos especiais é também inevitável sublinhar que esta cena reforça, sem dúvida, a dimensão ridícula dos esforços dos nossos aliados para reparar a fratura, indo por isso ao encontro dos sentidos presentes no romance. Em outras situações, como o episódio em que se mostra o enorme novelo azul que resulta do desfiar da meia por Maria Guavaira (Saramago, 1986: 18, 188), a imagem encarregar-se-á de sublinhar a indissociável ligação entre A Jangada de Pedra e o domínio do fantástico.

$\mathrm{O}$ mesmo efeito da imagem que pode valer mais do que as palavras - ou os ganhos decorrentes da transposição gramática intersemiótica -, acontece exemplarmente em dois episódios fundamentais. O primeiro é respeitante à cena em que, "sinal duma perversão evidente", as palavras "Nous aussi, nous sommes ibériques" (Saramago, 1986: 162) saltam fronteiras geográficas e políticas, sendo postas, em italiano, na boca de um já debilitado Papa João Paulo II, ou, em inglês, numa bandeira que o filme coloca a ser empunhada (pelo próprio Sluizer ${ }^{92}$ ) no mais mediático dos cenários: um campo de futebol. $\mathrm{O}$ segundo, em que a intencionalidade ideológica saramaguiana não apenas se mantém mas se acentua, é relativo ao quadro - facultado em inser $^{93}$ - em que se tece a crítica à cobardia política do chefe do governo de salvação nacional ${ }^{94}$.

\footnotetext{
${ }_{92}$ É também Sluizer quem encarna o papel de porta-voz da Comunidade Económica Europeia, por ocasião da leitura da "declaração solene" (ver supra).

${ }^{93}$ Ver supra, nota 19.

${ }^{94}$ Podem ainda mencionar-se as cenas relativas ao pânico-caos provocados pelas notícias do fenómeno e/ou pelas suas consequências (Saramago, 1986: 35, 37, 40, 97-98, 143, 235, 242).
} 
Após a notícia da prevista colisão com os Açores, partindo de um plano que se vai progressivamente fechando sobre um televisor portátil que anuncia uma notícia de última hora, a comunicação de que "a salvação está na retirada", assistimos a um Presidente da República Portuguesa cuja aparência oscila entre a fragilidade e o pânico, se não o choro contido. No romance, em que o papel é atribuído ao primeiro-ministro, e em cujas páginas as informações sobre o curso dos acontecimentos são também, com frequência, facultadas via rádio ou televisão $0^{95}$, as cores da incompetência, as emoções, já que delas falamos, surgem esbatidas num registo discursivo que, apesar de tudo, desanda em tonalidade idêntica à do filme. Num e noutro texto, portanto, a excitação inicial conferida pelo poder progride gradativamente para a cobardia do abandono do cargo (obliquamente prevendo fraquezas semelhantes de membros do real governo português ${ }^{96}$ ):

\begin{abstract}
Constituiu-se o governo de salvação nacional dos portugueses, começou logo a trabalhar, tendo o primeiro-ministro, o mesmo, ido à televisão produzir uma frase que a história certamente registará, uma coisa no género, Sangue, suor e lágrimas, ou Enterrar os mortos e cuidar dos vivos, ou Honrai a pátria, que a pátria vos contempla, ou, O sacrifício dos mártires fará germinar as messes do futuro. Neste caso de agora, e tendo
\end{abstract}

\footnotetext{
${ }^{95}$ Ver, por exemplo, Saramago, 1986: 31, 39, 49, 51-52, 56, 189, 202-203, 235, 321.

${ }^{96} \mathrm{Na}$ sequência da derrota do Partido Socialista nas eleições autárquicas de dezembro de 2001, António Guterres demite-se do cargo de primeiro-ministro e, em julho de 2004, Durão Barroso, alegando funções de relevante interesse nacional (a presidência da Comissão Europeia), abandona o mesmo cargo. A crise política provocada é semelhante em ambas as situações. Lembramos que, no romance, o governo de salvação nacional é constituído porque o governo português se demite, "com fundamento na evidente gravidade da conjuntura e no perigo coletivo iminente" (Saramago, 1986: 211). Salvaguardando embora as devidas distâncias entre a ficção e a realidade e, naturalmente, o facto de o romance de Saramago ser anterior aos acontecimentos referidos, não podemos deixar de considerar que as semelhanças permitem ilustrar uma ideia imanente da realidade política.
} 
em conta os particulares da situação, o primeiro-ministro achou por bem dizer apenas, Portuguesas, portugueses, a salvação está na retirada (Saramago, 1986: 223).

Deste modo, se, por um lado, as escolhas do adaptador podem por vezes reduzir a "interpretative richness" do texto-fonte escrito (Scholes apud Hutcheon, 2006: 70), por outro lado, "for visually oriented filmmakers, the opposite is true. They can move from the single-track language to a multitrack medium and thereby not only make meaning possible on many levels but appeal to other physical senses as well" (Hutcheon, 2006: 70). E, talvez, de todos os momentos que do romance passam para o ecrã - num entendimento que mais uma vez assumimos subjetivo e, por isso, não consensual - o que nos parece que mais ganha em emoções é o que se refere ao episódio em que as duas mulheres, primeiro Maria Guavaira e depois Joana Carda, se deitam com Pedro Orce, inevitavelmente provocando a momentânea desunião no coeso grupo dos cinco humanos e um cão ${ }^{97}$ (Saramago, 1986: 287-291).

Apesar da sensibilidade e do rigor com que José Saramago (ou o narrador por ele) descreve as atitudes das suas personagens, a carga dramática do episódio é intensificada no filme: pelo enquadramento sonoro (da responsabilidade de Henny Vrienten), pelo aproveitamento do bucolismo da paisagem (fotografia a cargo de Goert Giltaj) ou pela expressividade dos rostos dos atores - o português Diogo Infante no papel de Joaquim Sassa, entre a incredulidade sarcástica e a ira;

\footnotetext{
${ }^{97}$ Lembramos a importância dada ao cão, principalmente em A Jangada de Pedra e em Ensaio sobre a Cegueira (Arnaut, 2008: 195-196), e sublinhamos que, nesta linha, o espírito da obra saramaguiana é também mantido pelo facto de o genérico (inicial e final) do filme de Sluizer incluir, no elenco de atores, Golfo, o cão que tomará o nome Fiel, substituindo o de Constante, por "sugestão de Maria Guavaira" que "tinha lembrança de haver lido esse nome num livro qualquer" (Saramago, 1986: 267, ver Saramago, 1982 [1980]: 229). Segundo Saramago, "o cão é uma espécie de plataforma onde os sentimentos humanos se encontram. O cão aproxima-se dos homens para os interrogar sobre o que é isso de ser humano" (Gómez Aguilera, 2010: 158).
} 
o espanhol Gabino Diego tornado José Anaiço, entre a serenidade e a melancolia provocadas pelo pontual triângulo amoroso protagonizado pelas corajosas Maria Guavaira-Icíar Bollaín e Joana Carda-Ana Padrão e por um sempre tímido Pedro Orce-Federico Luppi.

A palavra cristalizada dá lugar, portanto, ao tranquilo rodopio das emoções provocadas por uma resolução que, em cadeia, ilustra uma importantíssima dimensão temática da ficção saramaguiana: a solidariedade ou, talvez melhor, a compaixão pelo outro, ou a caridade, que, em episódio semelhante, também surge em Ensaio sobre a Cegueira ${ }^{98}$. No (quase) final da viagem da Península Ibérica é também necessário que as personagens vistam a nova roupagem que interiormente foram adquirindo (conquistando?) e, por isso (apesar de, com certeza, se suspeitar da gravidade das consequências), não há como não compreender a decisão tomada. A vara com que Joana Carda riscara o chão não precisará, pois, de fazer mais um risco, agora para saber "quem fica de um lado e quem fica de outro" (Saramago, 1986: 290).

Talvez, de facto, não se recorra a tecnologia de ponta mas, vejamos, não terá o realizador, tal como o autor, pretendido construir uma espécie de história paralela às simples "histórias de fadas, embruxamentos e andantes cavalarias" (Saramago: 1986: 69)? A resposta afirmativa a esta questão - que nos parece permitir adequar ao contexto o comentário de Joana Carda sobre os futuros companheiros de viagem, separados "da lógica aparente do mundo" (Saramago, 1986: 147) - implica aceitar a singeleza dos procedimentos técnicos, ou a própria ingenuidade da representação de um José Anaiço (quase) sempre acompanhado, em assumido tom hitchockiano99,

\footnotetext{
${ }^{98}$ Referimo-nos ao momento em que a rapariga dos óculos escuros, "a mais bonita de todas as que aqui se encontram, a de corpo mais bem feito, a mais atraente, a que todos passaram a desejar quando correu a voz do que valia, foi afinal, numa noite destas [por pura caridade], meter-se por sua própria vontade na cama do velho da venda preta, que a recebeu como chuva de verão" (Saramago, 1995: 170-171).

${ }^{99}$ Ver Saramago, 1986: 70, 112.
} 
do bando de estorninhos. Implica, em suma, aceitar, como escreve José Saramago, que "Estranho é o destino das palavras" (Saramago, 1986: 79), principalmente quando o escritor põe e o cineasta dispõe $\mathrm{e}^{100}$.

\section{REFERÊNCIAS BIBLIOGRÁFICAS}

A JANGADA DE PEDRA (2002) [Filme], Realização de George Sluizer; baseado na obra de José Saramago. Lisboa: Lusomundo.

ANDRADE, S. C. (2010), "António Ferreira: no fim do mundo com Saramago", in Público/Ípsilon, 26 de fevereiro, pp. 14-15 (também disponível em: http://www. pngpictures.com/embargo/Y_26fev2010_Embargo.pdf (consultado em 12.11.2014).

Ante-Cinema em http://www.ante-cinema.com/critica-\%C2\%ABembargo\%C2\%BB-um-filme-embargado-na-longa-duracao/ (consultado em 21 de janeiro de 2015).

ARNAUT, A.P. (2008). José Saramago. Lisboa: Ed. 70.

ARNAUT, A. P. (2010). “Novos rumos na ficção de José Saramago: os romances fábula (As Intermitências da Morte, A Viagem do Elefante, Caim", in BAREL, A. B. (Org.). Os Nacionalismos na Literatura do Século XX: os Indivíduos em Face das Nações. Coimbra: MinervaCoimbra, pp. 51-70.

ARNAUT, A. P. (2014). "José Saramago: da realidade à utopia. O Homem como lugar onde", in BALTRUSCH, B. (Ed.). "O que transformou o mundo é a necessidade e não a utopia" - Estudos sobre Utopia e Ficção em José Saramago. Berlin: Frank \& Timme, pp. 31-52.

BAETENS, J. \& LITS, M. (Eds.) (2004). La Novellisation: du Film au Roman / Novellization: From Film to Novel. Leuven: Leuven University Press.

BARROS, E. (s.d.). "George Sluizer não quis fazer um filme de efeitos especiais espectaculares". Disponível em http://www.cinema2000.pt/ficha.php3?id=3190 (consultado em 09.03.2015).

100 "O homem põe, o cão dispõe" (Saramago, 1986: 153). Recordem-se, a propósito das alterações que fazemos ao provérbio de lavra saramaguiana, as ressalvas feitas na capa dos DVD que visualizámos, indiciadoras do propósito de não colagem literal ao texto-fonte: "Embargo. A partir da obra homónima de José Saramago" e "Baseado no livro do Prémio Nobel José Saramago. A jangada de pedra”. 
BELLO, M. R. L. (2008). Narrativa Literária e Narrativa Fílmica. Lisboa: Fundação Calouste Gulbenkian.

BRITO, J. B. de (s.d.). Literatura no Cinema. Disponível em: http://imagensamadasdotcom.files.wordpress.com/2011/04/literatura_no_cinema.pdf (consultado em 12.11.2014).

CARDOSO, A. H. (1995). Biblos. Enciclopédia Verbo das Literaturas de Língua Portuguesa. Lisboa / São Paulo.

CARDOSO, L. M. B. (2000). "Da literatura ao cinema: um percurso estético-literário do romance Cântico Final de Vergílio Ferreira”, in Lumina, v. 3, n 2, jul.-dez., pp. 43-52.

CHEVAlier, J. e GHEERBRANT, A. (1982 [1969]). Dictionnaire des Symboles. Mythes, Rêves, Coutumes, Gestes, Formes, Figures, Couleurs, Nombres. Édition revue et augmentée. Paris: Robert Laffont/Jupiter.

EMBARGO (2010) [Filme], Realização de António Ferreira; baseado no conto de José Saramago. Coimbra: Sofá Filmes.

FERREIRA, A. (2010). “Saramago sem traços contínuos”, entrevista conduzida por Manuel Halpern, disponível em: http://visao.sapo.pt/saramago=-sem-tracos-continuosf574883 (consultado em 12.11.2014).

FERREIRA, V. (1995), "Do livro ao filme", in Discursos. Estudos de Língua e Cultura Portuguesa, $\mathrm{n}^{\circ}$ 11-12, pp. 202-206.

GÓMEZ AGUilera, F. (2010). José Saramago. Nas suas Palavras. Lisboa: Caminho. GRIMAL, P. (2004). Dicionário da Mitologia Grega e Romana. Trad. Victor Jabouille, $4^{\mathrm{a}}$ ed. Lisboa: Difel.

HUTCHEON, L. (2006). A Theory of Adaptation. New York-London: Routledge.

HUTCHEON, L. (1989). Uma Teoria da Paródia. Ensinamento das Formas de Arte do Século $X X$. Trad. Teresa Louro Pérez. Lisboa: Edições 70.

LOPES, J. (s.d.), "Ficou por fazer um grande filme". Disponível em http://www.cinema2000.pt/ficha.php3?id=3190 (consultado em 08.03.2015).

QUADRADO, P. E. (2007), "Objecto Quase e o estatuto de obras menores", in MEDEIROS, P. \& ORNELAS, J. N. (Eds.). Da Possibilidade do Impossivel: Leituras de Saramago. Utrecht: Portuguese Studies Center, pp. 41-49.

SARAMAGO, J. (1973). "Embargo", dactiloscrito I, disponível em: http://purl.pt/13868/2/

SARAMAGO, J. (1973). "Embargo", dactiloscrito II, disponível em: http://purl.pt/13869/2/ 
SARAMAGO, J. (1973). "O Embargo". Lisboa: Estúdios Cor.

SARAMAGO, J. (1978). Objecto Quase. Lisboa: Caminho.

SARAmAgO, J. (1982 [1980]). Levantado do Chão, $3^{\text {a }}$ ed. Lisboa: Caminho.

SARAmAgO, J. (1986). A Jangada de Pedra. Lisboa: Caminho.

SARAMAGO, J. (1989). História do Cerco de Lisboa. Lisboa: Caminho.

SARAMAGO, J. (1989a). "Europa sim, Europa não”, in Jornal de Letras, Artes e Ideias, 10 de Janeiro, p. 32.

SARAMAGO, J.(1995). Ensaio sobre a Cegueira. Lisboa: Caminho.

SEIXO, M. A. (1979). "Recensão crítica a Objecto Quase, de José Saramago", in Colóquio/ Letras, $\mathrm{n}^{\circ} 49$, maio, pp. 77-79.

SILVA, A. M. da (2010). História da Unificação Europeia. A Integração Comunitária (1945-2010). Coimbra: Imprensa da Universidade de Coimbra.

STAM, R. (2006). "Teoria e prática da adaptação: da fidelidade à intertextualidade", in Ilha do Desterro, $\mathrm{n}^{\circ}$ 51, jul.-dez., pp.19-53.

TORRES, M. J. (2000). "Não li o livro, mas vi o filme. Algumas considerações sobre a relação entre cinema e literatura", in BUESCU, H. C. e DUARTE, J. F. (Coord.). Entre Artes e Culturas. Lisboa: Colibri, pp. 55-69. 


\title{
A NARRATIVA DA DESCONFIANÇA NA POLÍTICA: A FIGURAÇÃo do POLÍtíco
}

\author{
Ana Teresa Peixinho \\ Universidade de Coimbra / CEIS2O \\ Bruno Araújo \\ Universidade de Brasília / CEIS2O
}

\section{A personagem mediática}

No seu mais recente romance - Número Zero - Umberto Eco constrói uma ficção à volta do mundo do jornalismo, apontando, em jeito de caricatura, os piores vícios da imprensa no final do século XX. Numa das cenas que representa uma reunião de redação, o diretor do novo jornal Amanhã propõe que se construa uma reportagem sobre um magistrado italiano incomodativo ao status quo, procurando evidenciar os seus piores vícios e as falhas mais evidentes. Tratavase, portanto, de denegrir uma reputação:

Vejam bem que, hoje, para rebater uma acusação, não é necessário provar o contrário, basta deslegitimar o acusador. Portanto, eis o nome e o apelido do fulano, e Palatino dá um salto a Rimini, com um gravador e uma máquina fotográfica. 
Siga este servidor integérrimo do Estado, ninguém é jamais integérrimo a cem por cento, talvez não seja pedófilo, não terá assassinado a avó, não meteu ao bolso luvas, mas terá feito qualquer coisa de estranho. Ou, então, se me permitem a expressão, estranhifique-se o que faz todos os dias. (Eco, 2015: 99).

Tratava-se de pôr o jornalismo ao serviço da calúnia e da intriga política, construindo um imagem suficientemente duvidosa acerca de uma figura pública, para que o leitor, pelas inferências possibilitadas pelo texto, pudesse colar a pessoa em causa a um cenário de desconfiança e de duvidosa credibilidade, nem que para tal se tivesse de contornar os princípios mais básicos da deontologia profissional.

O que este episódio caricatural romanesco evidencia é um dos aspetos mais sensíveis da vida pública hodierna: a construção das imagens dos homens públicos feita essencialmente pelos media. Sabe-se que esta questão é hoje cuidadosamente trabalhada por poderosas máquinas de comunicação que, conscientes do valor da figuração mediática, cuidam cirurgicamente das informações que devem transpirar para os meios de comunicação acerca de políticos, desportistas e vedetas. Desde a forma de vestir, aos hábitos quotidianos, passando pelos costumes, crenças, fragmentos discursivos, tudo é trabalhado por forma a construir uma figura que encaixe num determinado modelo tido como o ideal.

Aquilo a que o público tem acesso acerca das figuras públicas e o conhecimento que possui sobre essas pessoas raramente é direto ou pessoal. Os atores sociais que povoam os diferentes media, quer em formatos noticiosos quer em produtos de entretenimento, decorrem de construções que mimetizam pessoas reais, com existência ontológica, pouco coincidindo, na maior parte dos casos, com os homólogos reais. Enquanto, nos mundos possíveis da narrativa 
ficcional, as personagens, mesmo quando inspiradas em pessoas, não têm obrigatoriamente de se fixar a essa imagem do mundo ontológico, no caso específico das narrativas ditas "naturais", como as jornalísticas, é indispensável essa correspondência ${ }^{101}$.

Quando as diversas figuras que povoam o nosso universo social - como é o caso de políticos de que aqui se fala - deslizam para as narrativas mediáticas, sejam elas ficcionais ou não, adquirem o estatuto de personagens, perdem a dimensão humana e complexa que ontologicamente possuem, para se verem reduzidas a uma soma de traços identificadores, submetidas a procedimentos retórico-textuais de figuração, que compõem os seus perfis, muitas vezes esquemáticos e incompletos, a partir dos quais os leitores ou espectadores formarão a sua opinião. Como alerta Marc Lits, a atividade de construir personagens pelos media é de uma enorme responsabilidade, pois, na maioria dos casos, são eles as únicas fontes de conhecimento que o público tem ao seu dispor (Lits, 2008). O mesmo é dizer que, quando falamos em pessoa / ator social e personagem mediática estamos, na verdade, a falar de duas entidades distintas, mesmo quando essa personagem integra narrativas com dever de referencialidade ${ }^{102}$. E essa construção é, não raras vezes, sobretudo quando se trata de homens da política, elaborada a partir de um tecido discursivo complexo em que se combinam a influência dos sofisticados assessores de imagem da comunicação política, a capacidade de triagem e de crítica do próprio jornalista, os discursos que se disseminam pelas redes sociais etc. O produto final, que chega ao público, é já o resultado de composições intersubjetivas,

\footnotetext{
${ }^{101}$ Explica Valles Calatrava: "La diferencia fundamental de estos relatos informativos (...) estriba fundamentalmente en su carencia de dimensión ficcional y máxima referencialidad y mimetismo con respecto a la realidad." (Calatrava, 2008: 21).

${ }^{102}$ Comenta Marc Lits, a respeito de figuras como as de Barack Obama ou Bill Clintton: “(..) il faut cependant admettre que la quasi-totalité des téléspectateurs et lecteurs de journaux ne découvrent ces deux personnes, éminemment médiatisées, que par les récits de presse qui les présentent à l'attention de l'opinion (...) Et ceux-ci construisent un personnage selon les critères de vraisembilité, souvent suggérés par les services de communication des hommes politiques en questions." (Lits, 2008: 144).
} 
dialógicas e altamente profissionalizadas. Porém, como bem assinala Mário Mesquita, "quando está em causa a "narrativa factual" (...) o problema não está em demonstrar que as coincidências com a "pessoa real" são fortuitas, mas que, pelo contrário, a personagem coincide, nos seus traços principais, com a pessoa "retratada"" (Mesquita, 2003: 132).

Não se trata aqui de ler à luz de critérios ontológicos de verdade ou falsidade os discursos ficcionais mediáticos, como é o caso daquele que será objeto de análise neste artigo, mas de perceber que a figuração é sempre uma atividade de mediação, que implica uma construção específica, feita quer em função de códigos societais, quer no respeito pelos códigos de género discursivo ou textual. Mesmo no caso das personagens jornalísticas, não se trata de pôr em causa a base factual das narrativas ou de enveredar por um discurso de suspeição que entende que aquilo que os media produzem é, regra geral, manipulação e distorção da realidade. Pelo contrário, deve perspetivar-se o discurso mediático, e dentro dele o jornalístico, precisamente pela sua essencialidade de discurso, só traduzível em textos, que são sempre uma construção semiótica de mediação, um processo de semantização do real, pelo qual os públicos acedem aos acontecimentos. Assumindo um indiscutível papel de mediação, os discursos dos media organizam os conhecimentos, permitem a troca de experiências, através da produção e reprodução de formas simbólicas, configuram a prática social e ditam, se não o como, pelo menos aquilo em que pensamos, moldando os nossos critérios de relevância. ${ }^{103}$

Neste sentido, o contributo dos estudos narrativos para o estudo dos media é absolutamente vital, pois são eles quem poderá fornecer as ferramentas analíticas e o quadro epistemológico de estudo do modo como os media funcionam como instâncias de sentido,

\footnotetext{
${ }^{103}$ A este respeito, João Carlos Correia explica que os media "ganharam uma dimensão importantíssima no que respeita ao estabelecimento de um significado comum e intersubjetivo acerca da vida quotidiana", adiantando que "esta influência se exerce sobretudo ao nível da relevância relativa aos temas em debate" (Correia, s/d: 9).
} 
nomeadamente na construção de personagens: "ser um repórter que lida com factos e ser um contador de 'estórias' que produz contos não são atividades contraditórias", afirma Gay Tuchman (1993: 259). A semantização operada pelos media e o modo como atribuem significados ao real exigem que estes recorram precisamente à narrativa como seu modo estruturante e, dentro dela, se privilegie a personagem como categoria central. Diremos, com G. Vattimo, que "os mass media assumem um papel determinante na sociedade pós-moderna", inscrevendo "a sociedade da comunicação num sistema de efabulação do mundo" (Vattimo, 1990: 13) e que essa efabulação é mediada pela intrínseca narratividade do mediático. Na verdade, os media são hoje uma das grandes fábricas de mitos contemporâneos, como já Roland Barthes demonstrara nas suas Mitologias ${ }^{104}$. Se, à partida, a narrativa deve mediar a realidade de uma maneira objetivada, ela exige um olhar crítico que consiga captar a sua essencialidade construída: não é um lugar de pura e simples reconstituição de factos, fingidos ou "reais", e quer as ações, quer as personagens que as protagonizam são sempre sujeitas a procedimentos de figuração e de construção ${ }^{105}$.

A personagem é uma categoria narrativa que tem estimulado, na última década, uma quantidade considerável de estudos de áreas muito diversas, da Psicologia às Ciências Cognitivas, da Literatura aos Media Studies. Longe vai o tempo em que se circunscrevia ao âmbito da literatura, como bem o assinalam Carlos Reis e Ana Cristina Macário Lopes: "Categoria fundamental da narrativa, a personagem

\footnotetext{
${ }^{104}$ Vejamos o que, mais recentemente, diz Marc Lits a este respeito: "Une étude détaillée des pages régionales des quotidiens permet d'observer comment les journalistes "mythifient" les sujets qu'ils traitent (...) Le fait même d'être mentionné dans un journal rend un personnage ou un événement, de banal et quotidien, mythique". (Lits, 2008: 21)

${ }^{105}$ Seguimos, assim, a hipótese avançada por autores como Phillipe Marion (Marion, 1997) ou Marc Lits (Lits, 2000), para quem o polo mediático, central no sistema social, se constrói segundo uma lógica narrativa, quer na sua produção, quer na sua receção: "Ainsi, le modèle narratif, dans le système médiatique, et tout particulièrement en télévision, contaminerait, médiagéniquement, l'ensemble du dispositif, de telle sorte qu'il est majoritairement construit et consommé sur le mode narratif" (Lits, 2000: 5).
} 
evidencia a sua relevância em relatos de diversa inserção sociocultural e de variados suportes expressivos" (Reis e Lopes, 2003: 314) ${ }^{106}$. A transdisciplinaridade que a afeta diz bem das suas potencialidades semântico-pragmáticas e ideológicas, na construção das narrativas que tecem a nossa identidade social. Num texto recente, $\mathrm{H}$. Heidbrink (Heidbrink, 2010: 67-110) salienta três aspetos importantes na abordagem ao estudo da personagem em contexto não ficcional: i) a relação entre persona e personagem; ii) a ténue fronteira entre real e ficcional; iii) e o facto de a personagem ser sempre uma construção semiótica, feixe de signos complexos e materialmente detetáveis, produto de procedimentos retóricos específicos. Se, na ficção, estas constatações decorrem do estatuto ficcional dos mundos possíveis criados pelo discurso, na narrativa de imprensa, ancorada que está a um pacto comunicacional de "veracidade" e de honestidade factual, já a questão merece outras explicações e adquire outros contornos.

$\mathrm{Na}$ verdade, qualquer estudo que se debruce sobre a figuração da personagem mediática deve contemplar, como já assinalado por alguns autores, o processo simplificador a que são sujeitos os atores sociais no interior das narrativas. Como Mesquita (2002) explica, a respeito da personagem jornalística, há uma clara tendência para a construção de personagens planas ${ }^{107}$, facto que se explica pela conjugação de alguns fatores que afetam a produção noticiosa: por um lado, a urgência de atualidade - que dita a velocidade de produção; por outro lado, a necessidade de adaptação dos discursos a

\footnotetext{
106 A partir da década de 90 do século passado, assiste-se à "ressurreição" desta categoria narrativa, em parte fruto de uma vasta revisão conceptual, operada no quadro de Estudos Narrativos progressivamente mais abrangentes, interdisciplinares e atentos à evolução das narrativas contemporâneas. Disso são testemunho os estudos narrativos cognitivistas, o incremento de investigações sobre a construção social de identidades, os media studies, os estudos culturais, entre outras atuais correntes de pensamento das ciências sociais e humanas.

107 "De acordo com E. M. Forster, responsável pela designação que aqui se adota, as personagens planas "são construídas em torno de uma única ideia ou qualidade: quando nelas existe mais de um fator, atinge-se o início da curva que leva à personagem redonda" (Forster)" (Reis e Lopes, 2003: 322).
} 
um público massificado e heterogéneo - o que impõe a eficácia narrativa em detrimento do aprofundamento das questões. Acresce a estes fatores a ténue fronteira entre o ficcional e o factual, que confere à personagem mediática um cariz complexo e ambíguo: se ela deve um respeito ontológico à figura factual que representa, também se afirma sempre por processos de construção, que envolvem um conjunto de procedimentos retórico-discursivos comuns à narrativa ficcional. Afirma Helen Fulton que "real individuals who form part of news stories therefore have their characters constituted from the sam kinds of discursive material as fictional characters" (Fulton, 2005: 237). Esta duplicidade é, na opinião de Ralf Schneider, absolutamente vital para se captar a essência da personagem, que vive na confluência de um conjunto de informações textuais e do papel proativo da leitura, processo dinâmico fundamentado em modelos cognitivos, sociocognitivos e emotivos (Shneider, 2001: 608).

Os recentes desenvolvimentos dos Estudos Narrativos cognitivos carrearam uma diferente compreensão do funcionamento e do valor da personagem mediática, partindo precisamente da sua natureza paradoxal: se, por um lado, ela é baseada em pessoas reais, por outro lado, é inquestionável que ela resulta de um processo de construção, em que intervêm signos e códigos mais ou menos complexos. O discurso mediático, ao construir figuras, está a propor quadros de leitura, molduras aos leitores e espectadores, a partir dos quais será compreendida a história e as suas personagens. Estas são geralmente associadas a atributos sociais, pessoais e a ações funcionais que levam à rápida identificação e, muitas vezes, à estereotipia.

Assim, no quadro da análise que aqui se propõe - que incidirá sobre a construção do protagonista de um filme - parece relevante chamar a atenção para um conjunto de procedimentos retóricos e narrativos que devem ser considerados na compreensão da construção da personagem do político no quadro de um filme satírico, com claros propósitos caricaturais. 


\section{O político como personagem nos media}

A passagem do século XIX para o XX, argumenta Paul Ricoeur (1965), foi marcada pela propagação de uma "hermenêutica da suspeição", surgida, em grande medida, graças às ideias disseminadas nas obras de Marx, Nietzsche e Freud. Por detrás dessa conceção está o entendimento de que todo discurso pretende ocultar interesses aos quais serve. Ainda que o filósofo estivesse a referir-se a um momento histórico bastante específico, o seu pensamento adquire hoje grande atualidade. De facto, um movimento de generalização da desconfiança como valor universal, particularmente associado ao universo da política, parece constituir parte do modus vivendi dos nossos dias. Variados fatores podem ser apontados como explicativos de tal fenómeno ${ }^{108}$, mas o objetivo central desta reflexão é, perspetivando os media como instâncias produtoras de sentido, compreender o papel que eles desempenham nesse contexto.

Com efeito, a mimetização mediática do político é presidida por um conjunto de signos culturais altamente complexos que participam a montante e a jusante do processo de semantização do mundo levado a cabo no desempenho mediático. Por isso, compreender o político como personagem nos e dos media exige problematizar outros elementos, que se juntam aos procedimentos retórico-narrativos a que fizemos referência anteriormente.

Entendemos, nesse sentido, que, no processo de construção da personagem, os media recorrem a uma gramática cultural, socialmente

\footnotetext{
${ }^{108}$ Não são novos os esforços para compreender os motivos da crise de confiança nas instituições políticas. Desde os anos 1970, uma corrente de pensadores conservadores, nos Estados Unidos da América, partiu da noção de crise democrática - em parte devido aos problemas de governabilidade inerentes à democracia, do ponto de vista desses autores - como fator que explicaria essa descrença. Mais recentes, contudo, são os esforços para analisar o papel que os meios de comunicação aí desempenham. Em diálogo com vários estudos da ciência política, Luis Felipe Miguel (2008) sistematiza três hipóteses explicativas do declínio da confiança nas instituições políticas: (i) a hipótese do cinismo crescente do público; (ii) a hipótese do fim das ilusões e (iii) a hipótese da perceção popular correta continuada. Em cada uma delas, os media exercem papel preponderante.
} 
partilhada, sobre as práticas políticas. Situada no plano da metanarrativa, como diria Motta (2013), essa espécie de ethos prévio sobre a política e os políticos é o que pode explicar, em grande medida, a forma como a figuração da personagem é desenvolvida nos media e a maneira pela qual é percebida pelo público. Em outras palavras, ao construir o político como personagem, os media tendem a incorporar valores constitutivos do imaginário cultural popular que estariam na base da configuração de abordagens estereotipadas sobre a política, como as que observaremos adiante na análise de uma narrativa cinematográfica sobre a vida de um político brasileiro em campanha eleitoral. No Brasil, como em qualquer outro contexto, não se pode compreender a fabricação do político nos media sem levar em consideração a forma como está estruturada a cultura política nacional. E sem perder de vista que essa mesma cultura, que nada mais é que o conjunto de valores e crenças com os quais os cidadãos interagem simbolicamente com a política, vê-se reforçada nas narrativas mediáticas com grande regularidade, tanto nas informativas quanto nas ficcionais.

Sobre a constituição da cultura política brasileira, os estudos de José Álvaro Moisés (1992) a respeito do processo de democratização do país fornecem importantes pistas de análise para o objetivo deste artigo de compreender o modo de figuração do político nos media $^{109}$. Recorrendo a sondagens realizadas no Brasil e em outros

${ }^{109}$ A ideia de cultura política aqui empregada provém dos estudos de Moisés, que a define como um consenso normativo mínimo sobre a democracia e as práticas políticas e inclui [...] "entre outras coisas, a generalização de um conjunto de valores, orientações e atitudes políticas entre os diferentes segmentos em que se divide o mercado político e resulta tanto dos processos de socialização, como a experiência política concreta dos membros da comunidade política" (Moisés, 1992: 7). Ora, para entendermos com maior clareza os valores presentes na cultura política brasileira é fundamental levar em consideração esses "processos de socialização", bem como "a experiência concreta" dos brasileiros com a política, no último século, particularmente no período pós 1988 , que marca a redemocratização do país. Dois exemplos que marcam esses dois fatores constitutivos da cultura política: o primeiro presidente depois da ditadura, José Sarney, não foi eleito diretamente, e Fernando Collor de Melo, o primeiro presidente realmente eleito pelo voto popular, sofreu um processo de impeachment por denúncias de corrupção, dois anos depois de ter ganhado a eleição como o "caçador de Marajás", ou seja, como aquele que lutaria contra os privilégios da classe dominante. 
países latino-americanos sobre a forma como as pessoas veem a democracia, o autor conclui que ainda vigoram, na mente dos cidadãos, conceções autoritárias e clientelistas, como as que caracterizaram parte da vida política do país durante considerável período de sua história, no Império e na República.

Não é mero acaso que, durante as recentes manifestações contra o governo da presidente Dilma Rousseff, pequenos grupos ecoem palavras de ordem pedindo o retorno dos militares ao poder. É fundamental recordar que até a redemocratização, no final dos anos 1980, os brasileiros mantiveram contacto com a democracia apenas entre os anos 1945 e 1964, isto é, entre o fim do Estado Novo e o Golpe Militar que impôs ao país uma ditatura de duas décadas. Antes disso, a república fora proclamada também por meio de um golpe e, nos anos 1930, Getúlio Vargas comandou uma ditadura de cariz populista. Esse processo histórico, portanto, não pode ser olvidado no âmbito de uma reflexão que procura compreender como os media constroem o político como personagem no interior de suas narrativas.

A cultura política brasileira também é marcada por uma forte personificação da atividade política e por um sentimento de desconfiança contínua em relação ao poder - dois valores que, atrelados aos demais, dariam tom ao delineamento das relações entre cidadãos, políticos, instituições e o próprio regime democrático ${ }^{110}$. No que ao primeiro valor respeita, há, de facto, no Brasil como em outros países, uma tónica na figura individual do político, naquilo que ele diz ou faz, nos aspectos mais interessantes da sua biografia,

\footnotetext{
${ }^{110} \mathrm{~A}$ propósito, no VI Congresso de Pesquisadores em Comunicação e Política, na cidade do Rio de Janeiro, Wilson Gomes (2015) identificou um paradoxo curioso: como compreender os elevados índices de desconfiança nas instituições políticas brasileiras, se o Brasil vive hoje o período mais duradouro de estabilidade democrática da sua história?
} 
vistos como grandes estratégias de imagem pelos profissionais do marketing político ${ }^{111}$.

No que ao primeiro valor respeita, há, no Brasil, uma tônica muita acentuada na figura individual do político, e menos no partido político a que pertence. Trata-se de uma espécie de culto à personalidade, naturalmente com menos intensidade do que aquele que se observa num país vizinho como a Argentina, que possui mesmo uma ideologia chamada de peronismo, em referência a Juan Domingo Perón, ex-presidente do país, fundador, em 1946, do Partido Justicialista de la Republica Argentina, da ex-presidente Cristina Fernandéz de Kirchner. No Brasil, a paixão pela dimensão individual do político é visível, nos media, na recorrente importância dada a aspectos triviais e personalistas de sua vida, que aparecem estrategicamente ao lado de declarações do político ou são narradas em episódios que envolvem a sua atuação profissional.

Do ponto de vista da comunicação política, o valor da personalidade é igualmente muito explorado, mas como estratégia de promoção de imagem. Aqui, o destaque a aspectos biográficos que façam com que o público se identifique com o político, além de uma composição que o coloca sempre como guardião da moralidade e da decência no manejo da coisa pública são apenas dois dos exemplos mais emblemáticos do modo como a personalidade figura como valor essencial na cultura política brasileira. Não é por acaso que a narrativa que analisaremos a seguir se estrutura em torno da vida pública e privada de um político-candidato à Presidência da República.

Relativamente ao valor da desconfiança, os brasileiros parecem confiar cada vez menos nas instituições políticas da democracia, como deixam perceber os resultados do Índice de Confiança Social 2015 - pesquisa realizada pelo Instituto IBOPE Inteligência, com

\footnotetext{
${ }^{111}$ Em outro estudo, constatamos que o valor da personificação da vida política aparece com força ainda maior na cobertura jornalística de casos de corrupção política (Araújo; Jorge, 2015).
} 
base numa amostra de 2.000 entrevistas — , segundo os quais instituições, atores políticos e processos eleitorais aparecem como os maiores alvos da desconfiança pública: numa escala de 0 (menor confiança) a 100 (maior confiança), as eleições e os sistema político recebem 33 pontos; a Presidente da República e o Congresso Nacional, 22; e os Partidos Políticos, em último lugar, aparecem com 17 pontos. Instituições fora do espectro político institucional, ao revés, são as que mais merecem a confiança da população, segundo o estudo: o primeiro lugar é ocupado pelo Corpo de Bombeiros, que recebem 81 pontos, seguidos pela Igreja, 71, e as Forças Armadas, com 63 pontos.

Interessante é observar, nesse sentido, a forma como esses valores predominantes na cultura política brasileira - mormente o valor da desconfiança na política, central nesta reflexão - são tecidos como fios narrativos constituidores da imagem do político nas narrativas mediáticas. Num artigo já clássico entre os estudiosos da personagem mediática, Mário Mesquita chama a atenção para o facto de os media frequentemente apostarem na criação de personagens planas com forte tendência para a tipificação e, portanto, para a estereotipia. De acordo ele, o resultado desse processo é a construção de "uma mimesis rudimentar que facilita os efeitos de identificação na medida em que reduz a complexidade dos seres retratados" (Mesquita, 2002: 126).

É de notar que o autor dialoga diretamente com o conceito de estereótipo - incluído no campo das ciências sociais pelas mãos de Walter Lippmann, em Public Opinion (1922) - que nos parece fundamental para compreender o processo de construção do político como personagem. Com efeito, um dos aspectos mais importantes da noção de estereótipo é a ideia de que ele essencializa e reduz a complexidade de uma realidade. Em uma conferência sobre os perigos da história única, a escritora nigeriana Chimamanda Adichie (2009) recorda que o estereótipo nem sempre revela mentiras, mas 
sempre oculta verdades ${ }^{112}$. Salientamos novamente que não interessa pensarmos em termos de verdade/mentira; ao contrário, importa chamar a atenção para o caráter reducionista e descaracterizador da complexidade humana e social presente nos processos de estereotipia, instaurados durante a figuração de certas personagens, nomeadamente as de tipo político, como a que a seguir analisaremos.

Não é, portanto, despropositado afirmar que a figuração do político nos media é realizada por meio de um processo de estereotipia que integra uma lógica mediática hegemônica de construção de mensagens e sentidos, articulada no âmbito de uma teia discursiva complexa, cuja constituição se dá por fatores de ordem sociocultural e por dialogias estabelecidas entre os diferentes agentes discursivos, jornalistas, fontes, leitores etc. Como acima explicitado, a simplificação e a superficialidade que presidem à mimetização de agentes públicos, com existência ontológica, no discurso mediático, constituem as bases para o funcionamento desse processo de estereotipia poderoso, possuidor de efeitos ideológicos muito claros ante o público: a figura do político, como representação de uma categoria indispensável às democracias liberais de cariz representativo, emerge envolta em pré-conceitos, ou seja, numa série de valores negativos previamente estabelecidos - um ethos prévio, como antes se disse - e constitutivos da cultura política nacional.

Destaque-se, todavia, que os media nem sempre atuam na fabricação direta dos estereótipos associados à política; estes são, porém, absorvidos, proliferados e tendem a ser naturalizados no espaço público por meio e em função do discurso daqueles. Com efeito, com a hegemonia que ainda detém em face de outras paisagens informativas, os media absorvem valores e crenças partilhadas por grande parte do público em relação aos políticos e à política e os reforça por meio de

\footnotetext{
${ }^{112}$ A conferência pode ser consultada no seguinte endereço: http://goo.gl/krtdT1. Consultado a 14 jan. 2015.
} 
narrativas informativas ou ficcionais ${ }^{113}$. Em função de uma reprodução exaustiva por meio da enunciação mediática, essas visões essencialistas da realidade tendem a ser naturalizadas no palco da esfera pública hodierna. Assim, adquirem o estatuto de espinha dorsal do jogo político mediaticamente representado. Essa naturalização é, de resto, traço bastante comum na relação dos cidadãos com a política: tendemos a vê-la como naturalmente vil e degradante, e não como “terreno de salvação”, isto é, de ação coletiva em torno do que é público e, sobretudo, como espaço de gestão de desejos conflitantes ${ }^{114}$. O processo de estereotipia instaurado pelos media encontra, desse modo, menos ancoragem na criação de estereótipos - embora se possa admitir algumas ocorrências, como veremos na análise a seguir - que na absorção, proliferação e, principalmente, na naturalização dessas marcas redutoras da complexidade do mundo, que funcionam como sinais estigmatizantes da generalidade dos agentes públicos.

\footnotetext{
${ }^{113} \mathrm{O}$ entendimento da ideia de processo hegemônico nos media é fruto de uma releitura empreendida do conceito de hegemonia de Gramsci, que pensou o conceito como processo simbólico de exercício do poder, não através do conjunto das instituições políticas e dos órgãos de controle e vigilância, e, sim, através da cultura. Segundo o teórico italiano, a hegemonia não é uma ação partidária, incrustada no aparelho de Estado - diferentemente da ideia de "ideologia" de Althusser —, mas uma ação de classe, ancorada na cultura. A partir desse entendimento é possível pensar os media como instâncias portadoras de um forte poder hegemónico, capaz de fazer passar modelos de entendimento do mundo, muitas vezes oriundos de discursos conservadores. O aspecto central da noção de hegemonia, portanto, [...] "não é o facto de operar forçando as pessoas, contra a sua vontade, a conceder poder àqueles que já são poderosos, mas sim o de funcionar obtendo o consentimento para formas de perceber o mundo que, de facto, fazem sentido" (Hersey, 2004:129).

${ }^{114} \mathrm{Com}$ isso, damos erroneamente à política o mesmo entendimento que Aristóteles deu aos fenómenos naturais, que são baseados pelo "princípio da necessidade", segundo o qual alguma coisa acontece porque tem necessariamente de acontecer. Deixamos, então, de entender a política pela via do "princípio da contingência". Oposto ao primeiro, o princípio da contingência, que abarca vários aspectos da nossa vida, define como contingentes aqueles fenómenos que são de uma maneira, mas que poderiam ser de muitas outras. Ora, como a política se afasta cada vez mais do seu verdadeiro modo de entendimento, - atividade a ser entendida pelo princípio da contingência - passa ser vista numa ótica naturalista, o que, por óbvio, destrói o seu sentido mais nobre de gestão de desejos em conflito. Há, portanto, o efeito ideológico e perverso de enxergarmos a política como terreno naturalmente corrompido, pelo qual os "homens de bem" nada podem fazer, a não ser afastar-se dela.
} 
Observar a relevância assumida pelo público - que contribui para a codificação e atua na descodificação dos enunciados mediáticos - é exercício elucidativo do modus operandi desse processo de estereotipia subjacente à figuração do político nos media. Quer no polo da codificação quer no da descodificação (Hall, 2003), media e público participam ativamente nessa enunciação constituidora de uma mimesis pública, que só faz sentido porque ambos partilham códigos culturalmente enraizados sobre a prática política.

Note-se, porém, que isso não significa concordância do público em relação à mensagem que recebe - e que ajuda a configurar, podendo mesmo refutá-la no quadro de uma "leitura contra-hegemómica" (Hall, 2003) - , mas, antes, que ele domina os signos necessários para o seu acolhimento cognitivo. É exatamente isso que faz funcionar o processo hegemónico mediático: se não houvesse, por exemplo, a partilha simbólica e intersubjetiva de valores e crenças entre a narrativa cinematográfica, que será por nós analisada, e o público, relativamente ao político e à política, muito possivelmente o processo de enunciação ver-se-ia comprometido; ainda que envolto em uma estrutura comunicativa tão poderosa na criação de estereótipos como a da comicidade e do humor na nossa atualidade ${ }^{115}$.

Esse modo de figuração do político na esfera pública mediática de nossos dias também se relaciona com a tendência mediática para adotar uma lógica de infoentretenimento ${ }^{116}$ no tratamento dado a certos temas da política, como forma de atração das audiências, por meio da construção de coberturas jornalísticas e de outros produtos e processos mediáticos que seguem uma liturgia teatralizada, a embrulhar os acontecimentos, situando-os num paradigma novelesco,

\footnotetext{
115 Sobre a criação de estereótipos em produções humorísticas, analisamos a construção da personagem Gina, do Programa Café Central, da RTP 2 (Araújo, 2013).

${ }^{116}$ Discutido por um conjunto de autores, o termo infoentretenimento (infotainment) é geralmente associado à prática que conjuga informação com modos de narração e efeitos poéticos que remetem para o campo do entretenimento.
} 
com regulares traços de espetacularidade e variados efeitos poéticos a compor a construção das narrativas sobre a política. Essa tendência mediática parece enquadrar-se no quadro mais amplo das transformações por que a civilização ocidental mais contemporânea tem passado, aparentemente desejosa de doses cada vez maiores de diversão e espetáculo. É nesse escopo que um autor como Mário Vargas Llosa, na coletânea de ensaios A Civilização do Espetáculo, situa a sua reflexão, para vaticinar, em relação à política, que:

\begin{abstract}
Hoje em dia, em todas as pesquisas de opinião sobre política uma maioria significativa de cidadãos opina que se trata de atividade medíocre e suja, que repele os mais honestos e capazes e recruta sobretudo nulidades e malandros que a veem como uma maneira rápida de enriquecer. [...] A que se deve o facto de o mundo inteiro ter chegado a pensar aquilo que todos os ditadores sempre quiseram inculcar nos povos que subjugam, ou seja, que a política é uma atividade vil? (Llosa, 2013:120-121).
\end{abstract}

A resposta à intrigante pergunta de Vargas Llosa é dada pelo próprio no decurso do mesmo texto, em que imputa, entre outras questões, parcela de responsabilidade aos media e a outras indústrias culturais, incluindo o próprio cinema. Quando essas instâncias criam narrativas que acabam por naturalizar conceções estereotipadas acerca da vida política nacional, dão poucos contributos para a construção de uma democracia plena. Não utilizando exatamente este termo, a reflexão do autor dialoga com o conceito de mediatização da política, que mereceu a atenção de autores como Pierre Bourdieu (1994; 2001; 2011) ou Manuel Castells (2009), ambos preocupados justamente com os efeitos que certas abordagens mediáticas da política terão sobre ela própria no terreno em que institucionalmente se realiza. 
Conquanto a mediatização da política, como a da justiça, seja tema de enorme relevância para qualquer trabalho que deseja entender as representações mediáticas da política, limitamo-nos a fazer referências a autores e textos hoje fundamentais para a compreensão de um fenómeno que não se limita ao universo político - o que terá levado um autor como Eliseo Verón, consciente da presença cada vez maior do fenómeno nas sociedades ocidentais contemporâneas, a dedicar parte significativa do seu trabalho intelectual à procura de pistas para entender a mediatização (Verón, 2014; Hjarvard, 2012; Castells, 2009). Torna-se imperioso ressaltar, de todo modo, em razão do que estamos a discutir, que o processo de estereotipia, que marca uma certa representação da política e dos políticos, parece funcionar como uma das pontas mais problemáticas do conjunto complexo de feixes narrativos, retóricos, discursivos e estilísticos que compõem as processualidades em torno das quais a mediatização da política se manifesta.

\section{Metodologia de análise}

O objeto de análise deste trabalho é o filme de comédia brasileiro, o Candidato Honesto, produzido em 2014, por Roberto Santucci, que conta a história de um político corrupto, candidato à Presidência da República ${ }^{117}$. Parte-se do princípio de que "analisar um filme é sinónimo de decompor esse mesmo filme", o que "implica duas etapas importantes: em primeiro lugar decompor, ou seja, descrever e, em seguida, estabelecer e compreender as relações entre esses elementos decompostos, ou seja, interpretar (Penafrina, 2009: 1).

Ora, tendo em consideração o objetivo deste texto, selecionar-se-á desta narrativa uma categoria que se afigura crucial — a personagem -,

\footnotetext{
${ }^{117}$ O filme está disponível no Youtube em: https://www.youtube.com/watch?v=95I$\mathrm{J}-\mathrm{dKO} 3 \mathrm{No}$
} 
quer porque o título assim o anuncia, já que se centra precisamente num predicado de personagem, quer porque toda a narrativa se desenrola em torno da figura principal: o político João Ernesto Praxedes que tem a ambição de se candidatar à Presidência da República. O objetivo da análise é, então, o de explicar os procedimentos retórico-discursivos de caricaturização da personagem, propondo uma leitura que se compagine com o enquadramento teórico explanado nas partes precedentes. Recorde-se que se parte da desconfiança como valor que deriva da cultura política brasileira e, de certo modo, estrutura a interação dos cidadãos com a política, funcionando aqui como uma metanarrativa, fundamental para a receção e para o estabelecimento de um protocolo de leitura (Motta, 2013) .

Embora não exista uma metodologia universalmente aceite para se proceder à análise, selecionou-se um conjunto de categorias que integram os principais procedimentos de construção de personagens narrativas, contribuindo para a sua figuração. Tendo em conta o género de filme - comédia - e o objetivo da leitura aqui proposta demonstrar como a figura do político é, no espaço público, sujeita a perspetivas de desconfiança -, parece importante cruzar quatro categorias de análise: a caricatura, a tipificação, a figuração e a metalepse.

A caricatura é um conceito correlato do de retrato, que exagera ou distorce certos traços de uma figura, sejam eles físicos, sociais ou comportamentais, com vista a criar efeitos grotescos, criticando e satirizando instituições, classes, grupos, etc. Tem fortes ligações a processos de estereotipia ${ }^{118}$, uma vez que se alimenta de um conjunto de traços - geralmente hiperbolizados - que o público facilmente identifica com os visados. Assim, parece incontornável utilizar, na

\footnotetext{
${ }^{118}$ Ressalve-se a diferença entre tipo e estereótipo: os tipos sociais são conhecidos por partilharem a mesma sociedade e realidade que os leitores, enquanto os estereótipos são imagens pré-concebidas do desconhecido: "Stereotypes are often regarded as the prototypical flat charcter (...) In fiction they differ, according to Dyer, to the extent that social types can appear in almost any kind of plot, while stereotypes carry with them an implicit narrative (Jannidis, 2013:29).
} 
análise que aqui se propõe, uma categoria narrativa subsidiária - o tipo - que se revela particularmente fecunda no que à figuração do protagonista deste filme diz respeito:

\begin{abstract}
(...) o tipo pode ser entendido como personagem-síntese entre o individual e o coletivo, entre o concreto e o abstrato, tendo em vista o intuito de ilustrar de uma forma representativa certas dominantes (...) em conexão estreita com o mundo real com que estabelece uma relação de índole mimética (Reis e
\end{abstract} Lopes, 2003: 411)

Esta definição sumária de tipo, feita pelos autores do Dicionário de Narratologia, aponta para três aspetos que se consideram muito importantes na análise que aqui se constrói: por um lado, o caráter estereotipado das personagens-tipo, capazes de um poder representativo indiscutível; por outro lado, a sua natureza mimética, que implica constantes procedimentos metalépticos com o mundo empírico, dada a conectividade da personagem com o espaço/tempo em que a ficção a coloca, e que tem necessariamente consequências na sua leitura e receção; finalmente, o processo de redução da construção do tipo, que deve privilegiar, sobretudo, um conjunto de atributos facilmente identificáveis pelos leitores.

O conceito de figuração, mais amplo que o de construção, é absolutamente essencial na construção desta análise. Assumindo-se que "a noção de figura não deve ser encarada como mero substituto terminológico do conceito de personagem", a figuração implica uma série de dispositivos de elaboração: "um conjunto de processos constitutivos de entidades ficcionais de feição antropomórfica, conduzindo à individualização de personagens em universos específicos, com os quais interagem" (Reis, 2015: 122). A figuração depende de múltiplos fatores, nomeadamente o medium por que a personagem é veiculada, na medida em que a tecnologia inerente a esse medium implica 
um conjunto de procedimentos e técnicas narrativas específicas que contribuem para a representação da personagem.

A metalepse, conceito oriundo da retórica ${ }^{119}$ mas explorado e adaptado à análise narrativa por Gérard Genette (Genette, 2004), revela-se muito fértil na leitura do fazer personagem em narrativas multimédia, nomeadamente naquelas, como é o caso do filme em questão, que jogam com uma leitura do real, propondo, através de estratégias de veridicção, a crítica a uma classe social, no caso, a classe política. Consiste, segundo o autor francês, em uma transgressão deliberada entre dois universos: o da narração e o da narrativa. Um dos autores responsáveis pela exportação do conceito para outros media que não a literatura, com particular enfoque em produtos multimédia, foi Werner Wolf, para quem a metalepse é "uma transgressão intencional e paradoxal entre mundos ontologicamente distintos e níveis representados em mundos possíveis" (Wolf, 2005: 91). Esta porosidade entre níveis e mundos - o da ficção e o da realidade - pode ser suscitada quer do ponto de vista do produtor da narrativa, quer do ponto de vista do leitor/espectador e pode ter efeitos diversificados: "The former, both as production (author's metalepsis) and as reception (reader immersion), tends toward aesthetic illusion whereas the latter (...) postulates a higher and purely fictitious reality" (Pier, 2014). No caso em apreço - a figuração do protagonista de o Candidato Honesto - o processo metaléptico é feito sobretudo do lado da receção, já que a construção, composição e modelação da personagem exigem uma atitude ativa e colaborativa do espectador, nomeadamente o seu conhecimento da cultura política brasileira e a partilha dos valores que a estruturam. Caberá ao espectador as inferências críticas que nunca são explicitadas ao longo da diegese.

\footnotetext{
119"It is important to bear in mind that although metalepsis has its roots in ancient rhetoric, narrative metalepsis is a recent concept in the history of poetics, with the practice itself, under different denominations, or none at all, reachinh back to antiquity in both literary and visual forms" ( Pier, 2014: s.p.)
} 
Definidas sumariamente as categorias que serão utilizadas nesta análise, importa explicitar a sua operatividade e definir o critérios que presidiram à sua escolha. Tratando-se aqui de uma personagem ficcional - porque integrada numa narrativa fílmica - que protagoniza uma diegese com claros intuitos satíricos, deve procurar-se compreender de que modo ela é construída com um conjunto de atributos que permitem lê-la como símbolo do grupo social alvo de crítica: a classe dos políticos no Brasil. O mesmo é dizer que é fundamental entender a sua dimensão histórico-social, a sua integração geocultural e a sua incidência temática, que a tornam suscetível de fácil identificação pelo espectador. Por outro lado, tendo em consideração o género em questão - um filme humorístico - parece fundamental compreender a consumação do processo caricatural, feito através da hiperbolização de marcas concretas - desde a indumentária, ao discurso ou às relações com outras personagens - que pré-condicionam quer o processo de figuração do protagonista, quer a sua leitura.

\title{
4. A figuração do político no filme $O$ Candidato Honesto
}

\author{
Político: Parece que eu estou tendo negócio de crise de \\ consciência. \\ Assessor: Oh, João, político não tem isso não. \\ Político: O quê, crise? \\ Assessor. Não, consciência! \\ Diálogo extraído do filme O Candidato Honesto (2014, \\ Globo Filmes)
}

A análise de que doravante nos ocuparemos exige que descrevamos, ainda que de forma sucinta, o conteúdo do filme em questão. o Candidato Honesto, com selo da Globo Filmes, conta, como se 
disse, a história de um político candidato à Presidência da República que se encontra em plena campanha eleitoral. Para obter a simpatia do eleitorado, a personagem principal, João Ernesto Praxedes - interpretado pelo ator Rodrigo Hassum - segue à risca as orientações construídas como estratégias de propaganda por especialistas em comunicação política. Nas várias cenas em que aparece em público, o candidato adapta o seu discurso aos desejos da plateia que o ouve, repetindo, em diversas ocasiões, que esta ou aquela comunidade, este ou aquele ideal, serão a sua prioridade tão logo assuma o cargo de presidente. Em outras ocasiões, mostra-se a preocupação dos diretores de campanha com a construção de uma imagem de homem honesto, comprometido com a causa pública e com a defesa da ética e da moralidade na vida política. Em uma das cenas de diálogo entre João Ernesto, candidato do Partido da Ética Democrática Nacional, e o principal assessor de campanha, a personagem teatraliza a frase "Eu quero um Brasil melhor", olhar no horizonte, seguida por uma enorme gargalhada em tom de deboche. Antes de cada aparição pública, assessores sugerem a utilização de camisas amassadas como forma de demonstrar aos eleitores que o candidato tem trabalhado arduamente. Fora dos holofotes mediáticos, para os quais é vendida a imagem de homem humilde e desapegado de grandes luxos, João Ernesto passa os momentos de descanso, ao lado da mulher e dos filhos, numa mansão luxuosa, afastado dos olhos públicos, aonde chega de helicóptero e de onde ensaia discursos fajutos, enquanto enverga uma faixa presidencial de imitação. Cenas assim proliferam ao longo de toda a narrativa, demonstrando o que pode haver de mais gravoso no mundo político: o recurso a práticas antirrepublicanas e antidemocráticas para se chegar ao Poder a qualquer custo.

O ponto nevrálgico da narrativa - aquilo que, em nossa opinião, constitui a estratégica discursiva de maior vitalidade para a construção de uma profunda ironia, com impacto direto na figuração da personagem - é o momento em que, inesperada e involuntariamente, João 
Ernesto perde a capacidade de mentir - algo que os produtores do filme tentam fazer passar como improvável —, após promessa feita à avó que, no leito de morte, apela para que ele adote uma postura de homem honesto na política. Desprovida daquilo que parecia ser condição para a orquestração de estratégias de comunicação política eficazes, visto que, antes desse acontecimento, aparecia em primeiro lugar nas sondagens eleitorais, com expressiva margem de manobra em relação ao seu adversário, a personagem começa a atuar como um ator que resolve descumprir o script previamente estabelecido pelos diretores.

As consequências são retratadas ao longo de quase todo o filme, em cenas que apelam ao riso dos espectadores, por retratarem, de modo profundamente caricatural, o universo da política. A caricatura é aqui construída por meio de estratégias retórico-discursivas que, quer no plano linguístico quer no plano imagético, distorcem e hiperbolizam situações que, conquanto existam no mundo empírico, podem não ser necessariamente a regra. Assim, desde a atuação no âmbito familiar - instado a opinar sobre a roupa da esposa, João Ernesto não titubeia em dizer que ela estava feia e mal vestida - até à maneira de se relacionar com apoiantes de sua campanha - há uma cena em que ele nega o dinheiro proveniente da doação de fiéis, oferecido por um pastor evangélico que, na condição de parlamentar, pleiteava, desde aquele momento, uma vaga de ministro em seu futuro governo - João Ernesto dava sinais de absoluto deslocamento de uma identidade cirurgicamente construída por seus diretores de campanha, em atitudes jamais pensadas, não fosse a perda das capacidades de dissimular e mentir.

Desse modo, existe uma declaração tácita, por parte do enunciador narrativo, de que a dissimulação e a mentira são valores constitutivos do ethos político, que, para ser bem-sucedido, dever-se-ia estruturar em torno deles. Por detrás desse protocolo de leitura possível, subjaz certamente o reforço da desconfiança em relação à política - que, 
na qualidade de valor nuclear da cultura política brasileira, funciona, na narrativa fílmica aqui analisada, como elemento metanarrativo estruturante de um processo de estereotipia que se vai aprofundando à medida em que surgem outros elementos retórico-discursivos de ordem mimética - porém hiperbolizados e, por isso, tendentes a generalizações inoportunas - a aproximar o mundo possível da ficção da dimensão ontológica do mundo empírico. No caso específico de uma narrativa cómica, essa chave de interpretação é acionada e posta em funcionamento no instante mesmo em que o espectador - confrontado, no vídeo que publicita o filme, com a expressão “acredite se puder", em referência à impossibilidade da mentira por parte de um político - sorri, com as cenas que visualiza, demonstrando, pois, que partilha dos valores e das ideias que configuram os códigos interpretativos de leitura da narrativa, sugeridos pelo seu enunciador. Dito de outro modo, o efeito cómico da narrativa fílmica, fundamental para a figuração da personagem, só é conseguido pela confluência de um conjunto de crenças e ideias sobre a classe política que estruturam a interação estabelecida simbolicamente entre enunciador e espectador.

Enredado num esquema de corrupção denominado "mesadinha" - que, metalepticamente, alude ao célebre escândalo do mensalão, desbaratado em 2005, envolvendo o suborno de parlamentares em troca de apoio político no Congresso Nacional - João Ernesto decide confessar a culpa aos jornalistas, aos quais tentou detalhar o modo como o esquema funcionava, mas acabou impedido, porque a direção da campanha resolveu afastá-lo da convivência pública, trancando-o em sua mansão, de forma a travar a queda a pique da sua popularidade. Novamente o enunciador sugere que falar a verdade, em política, é exercício que não se compagina com o objetivo da vitória nas urnas. Em outra cena, confrontado com a pergunta de uma mulher que atua como sua amante, e que lhe pergunta quando ele pretendia dispensá-la, João Ernesto foi taxativo: “Depois das 
eleições". Elucidativo também da estratégia de caricaturização é o momento em que, recorrendo a um pai de santo - figura de raiz africana, muito popular na cultura brasileira -, para tentar reverter a impossibilidade de dizer mentiras, João Ernesto trava um diálogo nestes termos:

Pai de santo: Eu estou acostumado com as criaturas das trevas.

João Ernesto: Ah, o demônio.

Pai de santo: Não, os senadores.

A cena de diálogo é elucidativa do modo como a comicidade inerente ao filme é transformada em elemento nuclear de uma estrutura comunicativa posta ao serviço da depreciação da classe política, como se percebe na associação das expressões "criaturas das trevas" e "senadores". No decorrer da narrativa, outras cenas contribuem para a construção de uma atmosfera caricatural que cola a figura do político ao estatuto de ser inescrupuloso e avesso a quaisquer atitudes éticas, situando-o no campo dos vícios e dos luxos, da imoralidade e da indecência, em que impera um completo desprezo pelas efetivas demandas sociais e pela própria democracia.

Com base na descrição desse elenco de cenas e em consonância com as categorias explanadas na metodologia, parece clara a instauração de um processo de estereotipia que se estrutura em torno do valor da desconfiança e se manifesta por meio da hiperbolização de diferentes traços constitutivos da personagem, contribuindo para a sua figuração e condicionando o campo interpretativo dos espectadores. As cenas que referimos antes dão forma a um conjunto de procedimentos metalépticos que conectam diretamente a narrativa ficcional à dimensão empírica do mundo real, umas das principais estratégias de construção de personagens. Recorde-se, por exemplo, que o lançamento do filme se deu no dia dois de outubro de 2014, quando o Brasil se encontrava em plena campanha eleitoral, a poucos dias para a primeira volta das 
eleições que reelegeriam Dilma Rousseff como Presidente da República, e que elegeriam deputados, senadores e os ocupantes dos poderes executivos e legislativos em todos os estados da Federação. Essa ligação entre a personagem - um ser de papel, como diria Barthes —, com o espaço/tempo em que a ficção a situa é conseguida pelos produtores da narrativa cinematográfica justamente pela mimetização de episódios ainda subsistentes na vida pública brasileira.

Conseguida por meio de um efeito de genericização do real, esses procedimentos caricaturais e metalépticos tendem a retirar à realidade e ao ator retratado a dimensão entrópica que demarca as existências ontológicas, conduzindo a leituras que influenciam diretamente o modo como os cidadãos se relacionam com a política e com os seus representantes. Quando situado, portanto, num contexto de construção de personagens-tipo, mormente daquelas relacionadas com agentes públicos, o efeito perverso desse tipo de estratégia é o de trazer no bojo uma série de estereótipos que, associados mimeticamente ao tipo retratado, reduzem a dimensão humana complexa de qualquer ser humano a um conjunto de traços redutores de identificação, que derivam de um processo arbitrário de seleções, com base em certos critérios, dos quais a ideologia, enquanto sistema de crenças que estrutura a nossa relação com o mundo, faz parte.

Como o que carateriza qualquer processo de estereotipia não é a suposta mentira que transporta, mas a sua tendência para essencializar, hiperbolizar ou reduzir entendimentos sobre culturas, acontecimentos e grupos sociais, o tipo de figuração que analisámos neste texto possui a consequência de estimular o processo já acentuado de depreciação da atividade política nas democracias ocidentais do nosso tempo, associando-se a outras constelações narrativas de mediatização da política que, ficcionais ou não, possuem o mesmo condão de estimular pensamentos segundo os quais o campo político não passa de um universo vil, degradante e alheio a desejos de natureza ética e moral. Assim como a cobertura jornalística da 
corrupção política pode contribuir para minar as instituições e o próprio regime democrático, quando realizada com o recurso a doses expressivas de espetacularidade novelesca, também a representação do ethos político, nos moldes do que observado neste filme, poderá ir na mesma direção (Cunha e Serrano, 2014; Araújo e Prior, 2015).

Outro aspeto que importa salientar é o tipo de relacionamento que a personagem estabelece com a imprensa, representada, no filme, por um jornal, mas sobretudo pela figura da jornalista a quem coube, por determinação do chefe de redação, acompanhar a campanha do candidato. Interessante é que, a despeito da enorme desconfiança de seus colegas de redação em relação ao protagonista, a jornalista, cujo pai havia sido beneficiado por políticas encabeçadas pelo candidato em tempos pretéritos, acreditava na sua honestidade, até ao momento em que, durante uma entrevista, João Ernesto confessa a sua participação no esquema de corrupção sob investigação. O curioso é que, munida de um conteúdo que poderia eliminar de vez as perspetivas do entrevistado de chegar ao poder, a jornalista se comove com a coragem do candidato em dizer a verdade, resolvendo não publicar o que tinha em mãos e pedindo demissão do jornal. Dias depois, no momento em que soube que João Ernesto não iria ao último debate presidencial, deixando o campo livre para o adversário, que agora possuía a maior intenção de votos, a jornalista procura-o na mansão onde estava preso, para convencê-lo a participar. Tendo-o convencido, os dois protagonizam uma verdadeira odisseia para driblar os seguranças e conseguirem chegar a tempo do final do debate. Quando o candidato adversário - prestigiado da plateia pelos antigos assessores de João Ernesto, que, depois de abandoná-lo, apostavam agora na candidatura adversária - já fazia as considerações finais, João Ernesto entra inesperadamente no estúdio de televisão para, numa mensagem aos eleitores, pedir desculpas pela má atuação enquanto homem público e apelar a que eles escolhessem de forma consciente os seus representantes. De seguida, desiste da sua candidatura, deixando o terreno 
livre para o seu adversário, naquele momento, seguidor das mesmas estratégias que tinham alçado João a ocupante do primeiro lugar nas sondagens, antes do episódio que lhe tirou a capacidade de mentir.

Ora, se, por um lado, essa cena parece construir uma leitura preliminar segundo a qual o arrependimento de João Ernesto representaria a ideia que de, na política, verdade, honradez e decência são valores passíveis de existência, o ato de renúncia da personagem pode conduzir o espetador a uma interpretação diferente: é que a desistência da personagem funciona como uma declaração tácita de que, uma vez arrependido e resolvido a agir de forma séria e ética diante da população, o sistema político automaticamente o extirpa, reafirmando-se como campo insuscetivel de ser habitado por quem possui tais qualidades. Aqui, como na maior parte das cenas, temos a construção de uma estratégia que contribui para a figuração de João Ernesto como ser portador de identidade desbotada, em face daquilo que necessariamente the conferiria o estatuto de político de sucesso.

Assumindo-se, em suma, como personagem-síntese entre o individual e o coletivo, na aceção dada por Reis e Lopes (1994) - e configurada em torno de traços estereotipados e, por isso, incapazes de traduzir, no ser retratado no filme, a complexidade e a dimensão plural própria da vida humana - a personagem é colocada no centro de uma narrativa para cujo entendimento interessa a mobilização de uma hermenêutica da suspeição, como diria Ricoeur (1965), e em função da qual o principal efeito social é o de aprofundar o valor da desconfiança desmedida em relação aos políticos e, por tabela, a depreciação da atividade e da prática políticas de nossos dias.

\section{Conclusões}

Este trabalho aprofunda a convicção de vários autores, quer do âmbito dos Estudos Narrativos quer do campo de Estudo dos 
Media, de que a narrativa é um poderoso terreno de exploração empírica a partir do qual é possível compreender a sociedade que nela se encontra retratada. Nesse contexto, a personagem, com toda a sua riqueza significante, emerge como categoria particularmente produtiva, na medida em que a sua figuração transporta sentidos que extrapolam a própria diegese e para cujo entendimento são necessários exercícios hermenêuticos que conjuguem saberes provenientes de diferentes áreas de conhecimento. Essa condição de cognoscibilidade inerente ao estudo da figuração de personagens é ainda mais verdadeira no caso particular das narrativas mediáticas, que funcionam como poderosas fabricantes de mitos contemporâneos, como alertou Barthes já em meados do século passado. De facto, assumindo um claro estatuto semiológico (Hamon, 1977), a personagem, em particular a mediática, acaba por se converter numa estrutura comunicante que veicula ideias, crenças e ideologias, com as quais o leitor/espectador interage.

Como procurámos demonstrar anteriormente, as diferentes estratégias que incidiram na figuração da personagem João Ernesto Praxedes, conferindo-lhe a condição de personagem-tipo, deixam antever um inevitável e poderoso poder representativo da classe política brasileira, que se manifestou mais claramente nas diversas cenas em que o enunciador parecia colocar, no mesmo patamar, os planos da ficção e da realidade, dando à personagem liberdade para transitar metalepticamente entre planos. Esses movimentos de ordem metaléptica, como lhes chamou Genette (2004), são os mais elucidativos da existência de uma sobrevida da personagem, ou seja, da capacidade que esta possui de continuar a existir fora do universo diegético, com diferentes impactos sociais, políticos e culturais, alguns dos quais resumiremos neste espaço conclusivo.

Num país com baixos índices de educação política e uma cultura democrática profundamente ténue, como é o caso brasileiro, a sobrevida da personagem de $O$ Candidato Honesto possui ao menos dois 
efeitos principais: primeiro, o de reacender conceções míopes em relação à política e ao seu funcionamento, por meio da associação de condutas moral e legalmente reprováveis à generalidade da classe política; em segundo lugar, essas mesmas abordagens possuem o condão de interferir, ainda que de modo indireto, na qualidade da relação que o cidadão-espectador-eleitor mantém com os agentes e as instituições que fazem funcionar a política. Essa derradeira influência fica muito evidente quando se percebe que os estereótipos que constroem a imagem da política se ancoram numa cultura ainda hoje marcada por valores e crenças como a alta desconfiança, o clientelismo ou o autoritarismo (Moisés, 1992).

Com efeito, a análise que desenvolvemos é elucidativa do modo como as indústrias culturais constroem constelações semânticas que aprofundam e naturalizam visões estereotipadas sobre o mundo empírico, intensificando, neste caso, o descrédito da atividade política e conduzindo a opinião pública a uma postura próxima da resignação em face de um sistema supostamente apodrecido e tendente a apodrecer quem dele se aproxima. Ao partilhar diariamente narrativas que depreciam a política pela forma como a retratam, o público é envolvido por uma atmosfera narcotizante - expressão de Lazarsfeld e Merton (1978) - que retira de cena qualquer possibilidade de esclarecimento efetivo. Por outro lado, o consequente processo de naturalização das práticas ilícitas como constitutivas do ethos político contemporâneo favorece a criação de climas difusos de indignação na esfera pública, muitas vezes parciais, porque focalizados em discursos condenatórios de partidos e atores políticos específicos. Em outras palavras, se o processo de estereotipia a que o político é submetido contribui para o alargamento dos estereótipos a toda a classe política, também se pode afirmar que, em certas ocasiões, determinados segmentos da política real podem ser mais afetados do que outros pela veiculação de ideias simplistas nos media, de acordo com as quais a corrupção política, por exemplo, 
seria solucionada com a simples extirpação de um ou outro político, desse ou daquele partido do jogo do poder.

Como consequência, é de admitir-se que esse mesmo público, mais ou menos narcotizado, seja levado a afastar-se do ecossistema político, passando a vê-lo unicamente como espaço de perpetração de práticas ilícitas protagonizadas por agentes que poderiam ser substituídos por indivíduos alheios ao universo da política. Basta recordarmos que os momentos de expressivo descontentamento público com as instituições políticas formais são quase sempre marcados pela emergência de movimentos autodenominados de apolíticos e apartidários que procuram deslegitimar o processo político. $\mathrm{O}$ mais terrível e extremo dos exemplos talvez seja o nazismo, que derrubou a República de Weimar, tendo justamente entre os seus argumentos a ideia de que era necessário moralizar a atividade política, numa ação que viesse de fora dela. O mesmo argumento serviu de base para estimular o suicídio de Getúlio Vargas, em 1954 - acusado por Carlos Lacerda, baluarte da direita brasileira, de comandar um "mar de lama" - e, dez anos mais tarde, em 1964, conduziu à derrubada do governo de João Goulart, com a instauração, em seguida, de uma ditadura militar no Brasil. Em nossos dias, o marketing político chega a valer-se do sentimento de desconfiança e de indignação por parte da população, para elaborar estratégias de campanha que depreciam a política: um de muitos exemplos é a letra de um single de campanha do então candidato José Ivo Sartori ao governo do Rio Grande do Sul: "acima da direita, acima da esquerda, acima de qualquer lado (...) o meu partido é o Rio Grande”. Note-se como a estratégia está justamente na tentativa de secundarizar ideologias, como se essas pudessem estar à margem dos processos deliberativos que caracterizam a atividade política.

Em completo descompasso com o que deveria ser o genuíno ethos político, a política aprece representada por João Ernesto Praxedes como como universo propício ao estreitamento do espaço público 
dos direitos e ao alargamento do campo dos interesses particulares dos que assumem cargos e dos que contribuem para a eleição daqueles - caso das grandes empresas - que, por meio de doações de campanha, realizam, na verdade, investimentos mais tarde recompensados pelos eleitos. Estreado num momento eleitoral real, $O$ Candidato Honesto certamente reavivou, na memória coletiva dos eleitores, a ideia de que a política se limita a ser um terreno fértil em atividade vil e degradante, povoado por agentes que antepõem os seus interesses paroquiais e de seus partidos ao interesse público.

Se é verdade, portanto, como alertam alguns autores (Muñoz \& Rospir, 1995), que a política e a democracia hodiernas não existem fora da arena mediática, parece razoável a afirmação de que, ao veicularem tais discursos estereotipados - tendo o valor da desconfiança como substrato narrativo central - os próprios media dão um contributo tácito para a manutenção do status quo, tanto em relação às mazelas que realmente existem na política, quanto no que respeita ao modo com que o cidadão comum se relaciona com ela.

\section{REFERÊNCIAS BIBLIOGRÁFICAS}

ARAÚJO, B. B. (2013). "Discurso mediático e o conceito de estereótipo. A construção da personagem Gina no programa Café Central”. In Silva, A. S. et al. Comunicação Política e Económica. Dimensões cognitivas e discursivas. Braga: Publicações da Universidade Católica Portuguesa, pp. 553-567.

ARAÚJO, B. B.; JORGE, T.M. (2015). "Discurso jornalístico e corrupção política: a construção de uma cobertura legalista e personificada em Veja e CartaCapital". In Verso e Reverso, Unisinos.

BIGNell, J. (1997). Media Semiotics. An Introduction. Manchester: Manchester University Press.

BOURDIEU, P. (1994). "L'emprise du journalisme". In Actes de la recherche en sciences sociales, 101-102, pp. 3-9. 
BOURDIEU, P. (2001). Sobre a televisão. Oeiras: Celta.

BOURDIEU, P. (2011 [1989]). O Poder Simbólico. Lisboa: Difel.

CASTELlS, M. (2009) A Sociedade em Rede.Trad. Roneide Venâncio Majer; vol 1. São Paulo: Ed. Paz e Terra.

CHARAUDEAU, D. (2000). Le discours d'information médiatique. La construction du mirroir social. Paris: Nathan.

CORREIA, J. C. (s/d). "O poder do Jornalismo e a mediatização do espaço público". In: www.bocc.ubi.pt/pag/jcorreia-poder-jornalismo.pdf (Consultado em março de 2013).

ECO, U. (2015). Número Zero. Lisboa: Gradiva.

FULTON, H. Et alii (2005). Narrative and Media. Cambridge: Cambridge University Press.

GEnetTe, G. (2004). Métalepse. Paris: Editions du Seuil.

HALL, S. (2003 [1980]). “Codificação/Descodificação”. In SOVIK, L. (org.), Da Diáspora: Identidades e Mediações Culturais. Belo Horizonte: Humanitas, pp. 387-404.

HAMON, P. (1977). "Pour un statut sémiologique du personnage" in Roland Barthes et alii, Poétique du récit, Paris: Seuils (Points), pp. 115-167.

HEIDBRINK, H. (2010), "Fictional Characters in Literary and Media Studies. A survey of the Research". Eder, J; Jannidis, F.; Schneider, R. (org). Charaters in Fictional Worlds. Understanding Imaginary Beings in Literature, Film, and Other Media. Berlim / Nova Iorque: De Gruyter, pp. 67-110.

HERSEY, J. (2004). Comunicação, Estudos Culturais e Media-conceitos-chave. Trad. Fernanda Oliveira. Lisboa: Quimera.

HJARVARD, S. (2012). "Midiatização: teorizando a mídia como agente de mudança social e cultural”. In Matrizes, v. 5, n. 2, jan-jun. 2012, São Paulo, pp. 53-91.

JANNIDIS, F. (2013). "Character". In The Living Handbook of Narratology http:// www.lhn.uni-hamburg.de/article/character (Consultado a 3 de maio de 2016).

LAZARSFELD, P.; MERTON, P. (1978). "Comunicação de massa, gosto popular e ação social organizada”. In Gabriel Cohn (org.). Comunicação e indústria cultural. São Paulo: Companhia Editora Nacional (texto original de 1948).

LITS, M. (2000). "Information, médias et récit médiatique”. In La question du récit à l'époque de la culture médiatique: mutations et ruptures, Deuxième colloque 
international du CRI, Montréal, 12-15 avril 2000. In: http://migre.me/tURwh. (Consultado a 15-09-2013)

LITS, M. (2008). Du récit au récit médiatique. Bruxelles: De Boeck.

LlOSA, M. (2013). A Civilização do Espetáculo. Trad. Ivone Benedetti. Rio de Janeiro: Objetiva.

MARION, P. (1997). "Narratologie Médiatique et médiagénie des récits". Recherches en Communication, N. ${ }^{\circ}$, pp. 61- 88.

MESQUITA, M. (2003). "Personagem Jornalística: da Narratologia à Deontologia". O Quarto Equívoco. O poder dos media na Sociedade Contemporânea. Coimbra: MinervaCoimbra.

MIGUEL, L. F. (2008). "A mídia e o declínio da confiança na política”. In Sociologias, n. 19, jan-jun, Porto Alegre.

MOISÉS, J. A. (1992) "Democratização e Cultura Política de massas no Brasil". In Lua Nova, n. 26, 5-51.

MOTTA, L. G. (2013). Análise Critica da Narrativa. Brasília: Editora da UnB

MUÑOZ, A.; ROSPIR, J. I. (1995). Comunicación Política. Madrid: Editorial Universitas. PEIXINHO, A. T. (2015). "Procedimentos retórico-narrativos de construção de personagens jornalísticas: o caso do jornal Expresso durante o verão de 2013". Revista de Estudos Literários, N.³. Coimbra: CLP/IUC, pp. 323-347.

PENAFRIA, M. (2009). "Análise de Filmes - conceitos e metodologia(s)". IN: VI Congresso SOPCOM, Abril de 2009 www.bocc.ubi.pt (acedido em dezembro de 2015).

PIER; J. (2014). "Metalepsis". In: The Living Handbook of Narratology http://www. lhn.uni-hamburg.de/article/metalepsis-revised-version-uploaded-12-may-2014\#Genette72 (Consultado a 3 de maio de 2016).

REIS, C. (2015). Pessoas de Livro. Coimbra: IUC.

REIS, C.; LOPES, A. C. (2003). Dicionário de Narratologia. 7. ${ }^{\text {a }}$ ed. Coimbra: Almedina. RICOEUR, P. (1965). De l'interpretation: essai sur Freud. Paris: Seuil, 1965.

TUCHMAN, G. (1980). Making News. A Study in the Construction of Reality. New York and London, The Free Press.

TUCHMAN, G. (1999). “Contando estórias”. In: Traquina, N. (org.). Jornalismo: questões, teorias e estórias. 2. ${ }^{\text {a }}$ ed. Lisboa: Vega, pp. 258-262. 
VALlES CAlATRAVA, J. (2008). Teoría de la narrativa. Una perspectiva sistemática. Madrid: Iberoamericana.

VATTimo, G. (1990). La société transparente. Paris: Desclée de Brouwer.

VERÓN, E. (2014). "Teoria da midiatização: uma perspectiva semioantropológica e algumas de suas consequências”. In Matrizes, v. 8, n. 1, jan-jun. 2014, São Paulo, pp. 13-19.

WOLF, W. (2005). "Metalepsis as a transgeneric and transmedial phenomenon: a case study of the possibilities of 'exporting' narratological concepts". In MEISTER, J. C. (ed.). Narratology beyond literary critiscism: mediality, disciplinarity. Berlin: de Gruyter, pp, 83-107. 
(Página deixada propositadamente em branco.) 


\title{
DE HERÓI A ANTI-HERÓI: \\ A CARACTERIZAÇÃo dA PERSONAGEM JOSÉ DIRCEU NA REVISTA VEJA
}

\author{
Aletheia Patrice Rodrigues Vieira \\ Universidade de Brasília \\ Liziane Soares Guazina \\ Universidade de Brasília
}

A construção das personagens da narrativa jornalística

Ao fazer cruzamentos com as narrativas literárias, Mesquita (2003) enfatizou as relações entre o processo de construção das personagens jornalísticas e a rotina profissional dos repórteres. Para a maioria dos jornalistas, especialmente para aqueles que estão em atividade nas redações, compreender que pessoas reais, retratadas em textos noticiosos, são representações que têm por objetivo gerar efeitos de sentido nos destinatários das mensagens e, portanto, constituem-se figuras do discurso, como afirma Motta (2013), é a negação de valores-notícias como a objetividade, exatidão e isenção.

A ideia de que o jornalismo constrói personagens e de que o jornalista conta estórias, conforme propõe Tuchman (1993), é, em geral, vista com desconfiança pela comunidade jornalística, por se 
considerar que o objetivo do jornalismo é divulgar fatos reais, ouvindo todos os lados envolvidos e com descrição fiel dos acontecimentos que geraram a notícia. No entanto, ao se identificar elementos narrativos nas matérias jornalísticas e as estratégias discursivas do narrador que evidenciam suas intencionalidades, conforme propõe Motta (2013), é possível observar mais amiúde as escolhas narrativas dos jornalistas e de que forma eles moldam as representações sobre o mundo da política.

Nosso objetivo neste artigo é identificar quais características, adjetivações e funções são atribuídas ao ex-ministro da Casa Civil José Dirceu, enquanto personagem da narrativa jornalística da revista Veja durante três momentos históricos diferentes. Como veremos mais adiante, nossas análises serão realizadas a partir da Análise Crítica da Narrativa proposta por Motta (2013), a partir de Campbell (1997) e Propp (2001). Também discorremos brevemente sobre o escândalo político-midiático (Thompson, 2002) em função do envolvimento atribuído a Dirceu no Escândalo do Mensalão.

Escolhemos a revista Veja uma vez que, além de ser um dos semanários mais conhecidos no Brasil, é também uma publicação que tem acompanhado, de forma sistemática, a carreira pública de José Dirceu, desde o período de atuação no movimento estudantil, na década de 1960, passando por momentos de exercício de cargos no período do Governo Luiz Inácio Lula da Silva, até a cobertura sobre o chamado Escândalo do Mensalão e posterior julgamento pelo Supremo Tribunal Federal. Importante destacar que os textos de Veja, muitas vezes, apresentam caracterização mais detalhada das personagens da notícia e dos episódios relacionados a elas do que a cobertura geral dos jornais.

Sendo assim, é possível identificar nos textos de Veja características, adjetivações e funções da personagem Dirceu em quatro matérias que envolvem o ex-ministro em momentos distintos de sua carreira política, desde 1968 até o ano de 2005, quando estourou 
o Escândalo do Mensalão. São elas: "Destruição e Morte: por quê?" (edição 5/1968), "O Congresso Interrompido" (edição 6/1968), "O homem que faz a cabeça de Lula" (edição 1770/2002) e "Ele assusta o governo" (edição 1916/2005).

Partimos da hipótese de que a imagem de José Dirceu foi construída ao longo dos anos por Veja à semelhança do que descreve Campbell (1997) como "ciclo do herói"; numa trajetória marcada por fases, surpresas e reviravoltas. Porém, no lugar de herói, a revista atribuiu a Dirceu características de anti-herói.

A vida de José Dirceu, que ganhou notoriedade em 1968 como líder do movimento estudantil na ditadura militar, é marcada por reviravoltas que são relatadas pela revista desde aquele ano, quando coincidentemente foi criada. Passou de liderança estudantil a exilado político, de articulador da campanha de Lula a acusado, durante o Escândalo do Mensalão, de chefe de um esquema de compra de votos no Congresso Nacional para aprovação de matérias de interesse do governo de Luís Inácio Lula da Silva, ainda no primeiro mandato do ex-presidente. Todos esses episódios biográficos de Dirceu foram alvo de notícias em Veja.

Em 2005, Dirceu pediu demissão do cargo de ministro-chefe da Casa Civil e, meses depois, teve o seu mandato de deputado federal cassado pela Câmara dos Deputados. Em 2013, após ser condenado pelo Supremo Tribunal Federal por corrupção ativa e formação de quadrilha (o ex-ministro foi absolvido deste crime após julgamento de recursos), José Dirceu foi preso e hoje cumpre a pena em regime domiciliar. Não voltou à carreira política e nem a ocupar posições de destaque no Partido dos Trabalhadores - PT, de que foi presidente e atuou de forma decisiva na campanha que levou Lula à Presidência da República em 2002.

Se a vida pública de José Dirceu é repleta de reviravoltas, a cobertura dedicada a ele pela revista Veja tem se concentrado em enfatizar, muitas vezes, as características pessoais do ex-ministro, suas ações 
e rede de relações privadas e públicas. Para se compreender como Veja define e desenha a personagem Dirceu, é necessário partir da noção de que as notícias são narrativas factuais, que se propõem a relatar os fatos de maneira mais próxima possível do real e "procura estabelecer reações lógicas e cronológicas das coisas físicas e das relações humanas reais ou fáticas" (Motta, 2013: 89).

As narrativas fáticas ou de ficção estão presentes na literatura, seja em romances, contos, novelas, ou filmes, e geram efeito de verossimilhança (Gancho, 2002: 10). O leitor acredita no que lê, mesmo a história sendo imaginária. No caso do jornalismo, há entre o narrador e o destinatário um contrato cognitivo baseado na credibilidade que delega ao jornal e ao jornalista-narrador a autoridade e legitimidade para dizerem a verdade sobre fatos reais (Motta, 2013: 39).

A personagem é quem realiza a ação no curso das narrativas. Segundo Gancho (2002), é a responsável pelo desempenho do enredo. O protagonista é uma classificação de personagem, a exemplo de José Dirceu nas matérias de Veja que serão analisadas, e de acordo com Abdala Júnior (1995: 44), os conflitos se desenvolvem em torno dele pois é "o ponto de referência para as alianças e confrontos entre os personagens".

A partir das funções (ou papel desempenhado pelas personagens, de acordo com Propp, 2001), é possível identificar quem são os protagonistas e antagonistas e a estrutura utilizada nas matérias jornalísticas - principalmente quando se trata de política, onde o conflito é categoria estruturante da narrativa política (Guazina \& Motta, 2010).

Ao citar Carlos Reis (1995), Mesquita (2003: 131) aponta que a personagem pode ser realçada durante determinado momento de sua vida, mas isso pode ser modificado ao longo das emissões, e ela assim desaparecer ou se tornar subalterna: "A personagem é considerada um lugar ideologicamente marcado, área privilegiada de investimento de valores e visões de mundo". 
Mesquita (2003) aponta ainda que a criação de personagens é uma atividade estruturante das práticas e do discurso jornalístico, que se assemelha ao valor-notícia da personalização proposto por Traquina (1993). Ele explica que as abordagens sobre personagens podem ser operativas em áreas não-ficcionais, como a reportagem, inclusive na caracterização de políticos.

Conforme o autor, as personagens jornalísticas são pessoas reais inseridas na narrativa jornalística, principalmente quando assumem situações de liderança ou de idolatria, reconstruídas aos olhos do leitor: "a personagem existe no quadro de uma narrativa que torna plausível sua representação" (Mesquita: 2003: 132). Mesquita considera que essa representação é fragmentada e que os traços biográficos de figuras públicas, como os políticos, são selecionados pelo jornalismo; isto é, não se conhece delas senão aquilo que a mídia diz a seu respeito. Ele defende que a personagem jornalística é construída a partir dos critérios de escolha do autor sobre o que é proposto pelo real, quando ordena os dados de acordo com o objetivo da narrativa.

Mesquita (2003: 137) também faz um paralelo entre a construção de personagens e a política. Segundo ele, as transformações das instituições públicas refletem nas mudanças estruturais das notícias e reportagens: "a personagem jornalística é um elemento estruturante, não só da narrativa midiática, mas também do próprio sistema político". Aqui observamos a similaridade de ideias de Mesquita (2003) e Thompson (2002), quando consideram que as opções eleitorais têm sido baseadas no caráter de quem pretende alcançar um cargo público, ou seja, dependem da pessoa do candidato, e não de "determinados temas e interesses" (Mesquita, 2003: 137).

Ainda de acordo com Mesquita (2003: 140), a construção da personagem jornalística começa com a negociação entre fonte e jornalista ao longo da apuração e depende das informações que farão parte da notícia: documentos, testemunho de pessoas, observação e interpretação dos gestos dos personagens, bem como seus comportamentos 
e obras. Para o autor, o que dá unidade, coerência interna e forma final às personagens é a criatividade do jornalista.

Sendo assim, não seria possível acessar a verdade biográfica das pessoas retratadas e/ou representadas nas matérias jornalísticas, uma vez que as personagens presentes nos textos são, em parte, fruto da subjetividade de quem escreve.

Por outro lado, Motta (2007: 153) destaca que a construção da personagem não se dá apenas no texto, mas também fundamenta-se na reconstrução/recombinação de elementos, muitas vezes contraditórios sobre as personagens por parte do leitor: "Os receptores (sic) do jornalismo conhecem as figuras públicas através de fragmentos que delas veicula o jornalismo".

Porém, há de se levar em consideração que o que se conhece das figuras públicas é também decorrente, na maior parte das vezes, da cobertura jornalística. Como veremos a seguir, a construção de personagens políticos ocorre num contexto de escândalos político-midiáticos nem sempre favorável aos políticos profissionais.

\section{A reputação e o escândalo político-midiático}

Nas sociedades democráticas contemporâneas, como é o caso do Brasil, a mídia passou a ocupar um papel de destaque na cobrança por honestidade e ética na política, principalmente por meio da divulgação de fatos que, ao longo de diferentes coberturas, constituem-se em escândalos políticos.

Os meios de comunicação deram visibilidade aos fatos do dia a dia relacionados à política e aos políticos que antes eram inacessíveis ao grande público, diz Thompson (2002). De acordo com o autor, a definição de escândalo inclui o fato de certos tipos de transgressões serem realizados em sigilo e que, ao se tornarem públicos, "são suficientemente sérios para provocar uma resposta rápida” (p.40). 
Na comunidade jornalística, o escândalo é um dos motivos que favorece a busca pelo "furo": "uma conquista que está associada ao brilho profissional, razão justificada de vaidade pessoal e que fornece prestígio" (Traquina, 1993: 55). Já para Waisbord (2000), as coberturas que envolvem a descoberta de atos de corrupção na política dão mais prestígio ao jornalista do que denúncias de injustiças sociais. Segundo ele, para alguns profissionais, é mais fácil apurar e escrever sobre problemas evidentes do que sobre as entranhas do poder, que quase sempre são inacessíveis caso não haja investigações.

Portanto, o sistema político-midiático molda, ao longo do tempo, os critérios de confiança/desconfiança dos cidadãos na política. Diz Thompson que, por meio da confiança, lidamos com a incerteza ou risco das ações e decisões que dependem dos outros. Implica a quem confia, pressupõe a possibilidade do desapontamento: "A confiança, como a reputação, é um recurso que não se consome com o uso. Pelo contrário, quanto mais ela é usada, maior será o estoque de confiança" (Thompson, 2002: 303). Thompson reitera que, em alguns casos, existe mais preocupação com a honestidade ou com a vida privada do político do que com a sua capacidade técnica: "Podem ser fonte de profundo desapontamento e assombro pois podemos perceber que indivíduos não correspondem às expectativas que deles tínhamos" (Thompson, 2002: 119).

Como os políticos, em geral, dependem da visibilidade midiática para serem bem-sucedidos em suas carreiras, passam a enfrentar as consequências da visibilidade midiática, entre elas, a vulnerabilidade aos escândalos e as denúncias. A histórica baixa confiança nos políticos, aliada ao poder da mídia em tornar (in)visível o jogo político, contribui para a manutenção da própria desconfiança da população na política (Guazina, 2014).

Uma das principais características gerais dos escândalos, trazidas por Thompson (2002: 40), que pode ser aplicada ao escândalo do Mensalão e à situação vivenciada por José Dirceu ao longo da cobertura 
jornalística de Veja sobre o caso, é de que "a revelação e condenação das ações e acontecimentos podem prejudicar a reputação dos indivíduos responsáveis por eles". O autor explica que, ao longo de suas carreiras, alguns políticos acumulam capital simbólico dentro dos aspectos da ética e da honestidade e levam tempo para conquistar esse patamar. O envolvimento em um escândalo de corrupção pode destruir o poder, o capital simbólico e a reputação rapidamente.

Após contextualizarmos a construção da narrativa jornalística e das personagens das notícias no contexto dos escândalos políticos, vamos, a seguir, detalhar os aspectos metodológicos envolvidos na pesquisa.

\section{Aspectos Metodológicos}

É parte da Análise Crítica da Narrativa, elaborada por Motta (2013), a metodologia de identificação das características e funções dos personagens em narrativas jornalísticas. Ao se utilizá-la, assume-se que, a partir dessa identificação, o narrador pode traçar estratégias argumentativas para gerar efeito de sentido; no caso do jornalismo, o efeito de real, e assim convencer o destinatário da mensagem de que as informações relatadas são verdadeiras. A descrição como recurso de linguagem é, portanto, uma dessas estratégias.

A seguir, descreveremos as principais etapas de nosso processo de aplicação da Análise Crítica da Narrativa para esta pesquisa. Inicialmente, foi feita uma leitura geral das matérias para identificarmos como Veja se refere a José Dirceu em cada um dos momentos relatados nas matérias. Com base na análise de personagens proposta por Gancho (2002), foram identificadas as funções de José Dirceu em cada enredo (protagonista, antagonista ou secundário), sua descrição como personagem redonda (por meio da classificação das características físicas, psicológicas, sociais, ideológicas e morais) 
ou plana. Com a identificação das funções, foi possível traçar quais juízos de valor a revista atribui ao ex-ministro.

A partir das primeiras observações, definimos a hipótese de que a imagem de José Dirceu foi construída ao longo dos anos por Veja de maneira semelhante ao que propõe Campbell (1997) como o "Ciclo do Herói». Para o autor, o herói pode ser determinado pelas seguintes características: alguém que se destaca, é mais forte de que os outros seres ou possui poderes mágicos, capaz de salvar os fracos e oprimidos. Porém, ao contrário de um herói, Veja atribui a Dirceu características de anti-herói, conforme veremos a seguir.

A narrativa jornalística em torno de José Dirceu o apresenta como um personagem que exerce determinadas funções de acordo com o contexto histórico em que está inserido, principalmente, por ter tido destaque na política brasileira em vários momentos de sua trajetória, criando ao seu redor uma espécie de mito, o que é perceptível em relação à leitura das quatro matérias que retornam a assuntos do passado do personagem, já tratado em reportagens anteriores.

De acordo com Campbell, o ciclo do herói - semelhante aos resultados dos estudos de Propp - segue os seguintes padrões: nascimento, chamado, jornada aliada a uma luta norteada por sacrifícios e amor, capazes de revolucionar a vida do próprio herói e das pessoas a sua volta. A jornada é marcada por dificuldades que são superadas.

Em linhas gerais, eis algumas das constatações de Propp (2001): ao herói é feito o pedido para reparar um dano, ele aceita o desafio e decide ir; em seguida, ele é submetido ao ataque do inimigo ou antagonista; depois reage a esse ataque quando recebe poderes mágicos ou a ajuda de outros personagens para vencer o antagonista; mesmo após a vitória e o regresso, o herói sofre perseguições, consegue se salvar e reinicia sua busca até reparar o dano e ser reconhecido pelo feito.

O ciclo vivido pelo herói, de acordo com Campbell (1997) e suas funções traçadas por Propp (2001), é composto basicamente pelas 
seguintes fases (adaptado por Motta, 2011: 185) e que foram associadas à trajetória de Dirceu ao longo das quatro matérias analisadas:

- Partida, também nomeada como "chamado da aventura": é quando o herói segue o destino até a missão que lhe foi dada ou que ele assume pela necessidade de mudar alguma situação.

- Superação de dificuldades ao longo da missão: nesse momento ele pode receber a ajuda de seres mágicos para então voltar e completar a missão.

- Perseguição: consegue se salvar e reparar o dano.

- Retorno ou reintegração: dependendo de como a missão foi conquistada pode representar glória ou destruição do herói.

O anti-heroísmo também reúne essas fases, portanto, também o anti-herói pode passar por elas. Segundo Motta (2011), o anti-herói é marcado pela personalidade contraditória, sendo necessárias várias descrições psicológicas para que o leitor compreenda que também não se trata de um vilão. O anti-herói toma decisões e age baseado em suas condições físicas, pessoais e sociais, e abriga sentimentos como a culpa, o medo, a revolta. Motta (2011) considerou essas caracterizações ao analisar o anti-heroismo do personagem João de Santo Cristo, protagonista da música Faroeste Caboclo, da banda de rock nacional Legião Urbana.

\section{Caracterização de Dirceu em Veja: quatro momentos}

A seguir, destacaremos em quadros as principais caracterizações, adjetivações e funções da personagem Dirceu e os respectivos trechos em que aparecem nas quatro matérias de Veja analisadas. Como será possível observar, boa parte das caraterizações refere-se a aspectos pessoais do ex-ministro. 
Como mencionamos anteriormente, em 1968, ele atuou como líder estudantil em São Paulo e ganhou notoriedade com os protestos de resistência dos estudantes à ditadura militar nas ruas. É nesse contexto que estão inseridas: i) a matéria "Destruição e Morte: porquê?" (Veja, edição 5/1968, p. 14-21), que tratam da "Batalha da Rua Maria Antônia", quando os estudantes do Centro de Filosofia e Ciências Humanas da Universidade de São Paulo (USP) se confrontaram fisicamente com estudantes da Universidade Mackenzie, onde supostamente estavam infiltrados líderes de organizações da extrema-direita, entre elas, o Comando de Caça aos Comunistas (CCC); e a matéria: "O Congresso Interrompido" (Veja, edição 6/1968) que relata como se deu a prisão de José Dirceu e outros líderes estudantis após a polícia impedir a realização do $30^{\circ}$ Congresso da União Nacional dos Estudantes - UNE, em que Dirceu era um dos candidatos à presidência.

Na edição 5/1968, as principais funções e ações atribuídas a Dirceu ressaltadas são:

Quadro 1

\begin{tabular}{|l|l|}
\hline Função & Ações atribuídas pela revista \\
\hline Destaque como líder & $\begin{array}{l}\text { "José Dirceu e Luis Travassos) os dois líderes estudan- } \\
\text { tis mais importantes do Estado de São Paulo" (p.19). }\end{array}$ \\
\hline $\begin{array}{l}\text { Determinado a lutar contra } \\
\text { as forças conservadoras da } \\
\text { direita }\end{array}$ & $\begin{array}{l}\text { "Luis Travassos e Édson Soares, respectivamente, } \\
\text { presidente e vice-presidente da ex-UNE, somados } \\
\text { a José Dirceu, comandavam a resistência da } \\
\text { filosofia" (p.17). }\end{array}$ \\
\hline $\begin{array}{l}\text { Organizador das passeatas } \\
\text { e incentivador da violência } \\
\text { dos estudantes com } \\
\text { a polícia durante os } \\
\text { protestos. }\end{array}$ & $\begin{array}{l}\text { "José Dirceu, presidente da ex-UEE, conhecido } \\
\text { como organizador, providenciava pedras, garrafas, } \\
\text { rojões (...) comandando uma passeata em que } \\
\text { foram incendiadas quatro viaturas policiais" (p.19). }\end{array}$ \\
\hline $\begin{array}{l}\text { Após a batalha da Maria } \\
\text { Antônia, demonstrava can- } \\
\text { saço e fraqueza }\end{array}$ & $\begin{array}{l}\text { "São bons líderes? - José Dirceu e Luís Travassos } \\
\text { eram dois líderes fracos e fadigados. Nenhum (...) } \\
\text { parecia ter forças políticas nem capacidade de } \\
\text { liderança suficientes para decidir por todos os } \\
\text { estudantes brasileiros" (p.19). }\end{array}$ \\
\hline
\end{tabular}


Na mesma matéria, o repórter descreve também com riqueza de detalhes o espaço físico e o ambiente tenso entre os estudantes, diante dos confrontos por meio de ações de José Dirceu:

José Dirceu subiu em um monte de tijolos, cadeiras, corrimãos de escada e paralelepípedos, que serviam de barricada e fez um comício relâmpago. 'Não é mais possível mantermos militarmente a Faculdade, não nos interessa continuar aqui lutando contra o CCC, a FAC e o MAC, esses ninhos de gorilas. Um colega nosso foi morto. Vamos às ruas denunciar o massacre. A polícia e o exército de Sodré que fiquem defendendo a fina flor dos fascistas. Viva a UNE, abaixo a repressão. (Veja, edição 5/1968, p.19).

Na edição 6/1968, a principais características observadas foram:

Quadro 2

\begin{tabular}{|l|l|}
\hline Funções & Ações atribuídas pela revista \\
\hline $\begin{array}{l}\text { Um dos culpados pela } \\
\text { desordem causada pelo } \\
\text { Movimento Estudantil }\end{array}$ & $\begin{array}{l}\text { "Os rapazes e moças enrolados em cobertores } \\
\text { coloridos, no frio do começo da tarde de sábado } \\
\text { passado, não pareciam os perigosos líderes } \\
\text { estudantis do Brasil inteiro, presos durante o } \\
30^{\circ} \text { Congresso da ex-UNE, em Ibiúna" (p.12). }\end{array}$ \\
\hline Líder derrotado & $\begin{array}{l}\text { "José Dirceu, ex-presidente da ex-UEE paulista. } \\
\text { Dirceu - cabelo comprido, barba por fazer, olhar } \\
\text { cansado" (p. 12). }\end{array}$ \\
\hline Fugitivo da polícia & $\begin{array}{l}\text { "Os três líderes estudantis (José Dirceu, Luis } \\
\text { Travassos e Vladimir Palmeira) estavam com } \\
\text { prisão preventiva decretada, finalmente execu- } \\
\text { tada depois de muitas vezes terem enganado a } \\
\text { polícia" (p.12). }\end{array}$ \\
\hline
\end{tabular}

Pelo facto de as duas matérias terem sido em sequência, uma semana depois da outra, pode-se então considerar que, neste primeiro 
momento, Dirceu estaria passando pela primeira fase do ciclo do herói, quando foi chamado a cumprir a missão de resistir à Ditadura, mas esta foi interrompida quando foi preso.

Dentro da perspetiva de Gancho (2002), constata-se que José Dirceu é uma personagem redonda na narrativa das duas edições de Veja sobre o movimento estudantil publicadas em 1968 e também um dos protagonistas das ações. No Quadro 3 abaixo, estão as características predominantes nas duas edições, divididas em classificações, também propostas por Gancho (2002):

Quadro 3

\begin{tabular}{|l|l|}
\hline Características & \\
\hline Físicas & Cabelo e barba por fazer \\
\hline Psicológicas & Cansado e fraco \\
\hline Sociais & Líder Estudantil \\
\hline Ideológicas & Um radical de esquerda \\
\hline Morais & $\begin{array}{l}\text { Perigoso, incentivador de violência e } \\
\text { fugitivo da polícia }\end{array}$ \\
\hline
\end{tabular}

A matéria "O homem que faz a cabeça de Lula" (Veja, edição 1770/2002, pp. 46-52) discorre sobre a possibilidade de ascensão de José Dirceu ao poder por meio da eleição de Luís Inácio Lula da Silva nas eleições presidenciais de 2002. Nela, é feito um resgate histórico sobre o passado de José Dirceu, além de comparações e paralelos às atitudes e características atribuídas a personagem no passado e no presente. Podemos considerar que, ao fazer o cruzamento dessas informações, a revista pretende mostrar se há coerência entre as ações do ex-ministro durante a ditadura e no momento atual.

Veja anuncia também que ele pode ser um ministro estratégico de um eventual governo Lula. Na época, Dirceu era deputado federal pelo PT em São Paulo e presidente do partido. O texto é baseado 
em relatos históricos de José Dirceu - que foi entrevistado - e de outras pessoas que conviveram com ele no passado e conviviam no presente. No ciclo do herói, é possível afirmar que a matéria corresponderia à superação das dificuldades - que começaram na ditadura - e que Dirceu estaria prestes a completar sua missão, no caso, levar o PT ao poder.

Neste momento, Veja o descreve como um personagem importante para a história política do país, porém com o objetivo de desconstruir possíveis mitos heróicos. Um dos temas tocados em relação à desconstrução da personagem é o exílio de José Dirceu em Cuba, para onde foi após ter seu nome na lista de presos políticos que deveriam sair da prisão em troca do resgate do embaixador americano Charles Elbrik, em 1969. A revista levanta questões sobre o treinamento guerrilheiro que ele teria feito no país, que poderia ser utilizado em uma eventual volta ao Brasil caso integrasse a luta armada. Na matéria, o próprio Dirceu é citado como quem é contra esse método.

A vida real de José Dirceu é ainda mais espantosa de que as histórias que se criaram a respeito dele e é possível reconhecer no radical do passado muito dos traços do moderado de hoje (...) 'eu era contra o movimento estudantil mandar quadros para a guerrilha"” (Veja, edição 1770/2002, p. 47).

Na edição, Veja destaca que, no passado, durante o movimento estudantil, José Dirceu era cabeludo, rebelde, namorador, bonitão e falante. Um jovem radical, conhecido pela capacidade de organização e obsessão em controlar tudo, que comandou passeatas históricas e era referência entre os estudantes de sua geração.

Além do exílio em Cuba, outro assunto que ganha destaque é a clandestinidade. Após fazer plásticas no rosto, José Dirceu voltou ao Brasil em 1976 com outra identidade e casou com a empresária Clara Becker, que só descobriu quem o marido era, quando ele integrou 
a lista dos anistiados políticos da Ditadura em 1979, e precisou revelar o segredo.

Na edição 1770/2002, as principais funções e ações atribuídas a Dirceu ressaltadas são:

Quadro 4

\begin{tabular}{|c|c|}
\hline Funções & Ações atribuídas pela revista \\
\hline Centralizador e controlador & $\begin{array}{l}\text { "Na campanha petista à presidência } \\
\text { não se toma uma decisão sem o aval } \\
\text { de José Dirceu, que controla tudo com } \\
\text { mão de ferro" (p.46). }\end{array}$ \\
\hline $\begin{array}{l}\text { Se tornou um político da esquerda } \\
\text { moderada }\end{array}$ & $\begin{array}{l}\text { "Um ano antes da aliança do PT } \\
\text { com o PL, José Dirceu já dizia, em } \\
\text { conversas reservadas com capitães de } \\
\text { indústrias, que o vice de Lula seria } \\
\text { um empresário, ato que simbolizaria a } \\
\text { união capital-trabalho" (p.46). }\end{array}$ \\
\hline $\begin{array}{l}\text { Assim como na ditadura, continua } \\
\text { sendo organizador }\end{array}$ & $\begin{array}{l}\text { "É um leitor voraz de pesquisas e } \\
\text { planeja eventos da campanha (...) traça } \\
\text { organogramas e se gaba de administrar } \\
\text { o PT como uma empresa" (p.51) }\end{array}$ \\
\hline É misterioso & $\begin{array}{l}\text { "Da sua experiência na } \\
\text { clandestinidade, ele aprendeu a agir } \\
\text { nas sombras (...) tem uma agenda } \\
\text { repleta de encontros secretos" (p.51). }\end{array}$ \\
\hline Fez escolhas oportunas & $\begin{array}{l}\text { "Se não tivesse feito sua conversão a um } \\
\text { esquerdismo menos ortodoxo, não seria } \\
\text { o líder de um partido que agora disputa } \\
\text { a presidência da República" (p.52) }\end{array}$ \\
\hline Não teria amizades sólidas & $\begin{array}{l}\text { "O economista Paulo de Tarso } \\
\text { Venceslau, que saiu do PT em } 1997 \\
\text { (...), solta a língua quando fala de José } \\
\text { Dirceu. 'Ele tem fome de poder e seu } \\
\text { estilo é jogar uns contra os outros para } \\
\text { se manter por cima"” (p.51). }\end{array}$ \\
\hline
\end{tabular}

No Quadro 5 a seguir, com base na classificação de Gancho (2002), destacamos as características mais marcantes de José Dirceu na matéria da edição 1770/2002: 
Quadro 5

\begin{tabular}{|l|l|}
\hline Características & Características atribuídas pela revista \\
\hline Físicas (Passado) & Cabeludo e bonito \\
\hline Psicológicas & Centralizador e organizador \\
\hline Sociais & Deputado Federal e presidente do PT \\
\hline Ideológicas & Um esquerdista moderado \\
\hline Morais & $\begin{array}{l}\text { Age nas sombras e enganou sua } \\
\text { primeira mulher }\end{array}$ \\
\hline
\end{tabular}

Já a matéria "Ele assusta o governo" (Veja, edição 1916/2005, p. 57-62), número em que Dirceu é capa, repercute as acusações de Renilda Fernandes de Souza, mulher do publicitário Marcos Valério (acusado de ser operador financeiro do esquema do Mensalão) em depoimento à Comissão Parlamentar Mista de Inquérito - CPI dos Correios. A Comissão tinha como objetivo investigar o caso no âmbito do Congresso Nacional, e Renilda Fernandes de Souza teria testemunhado a presença de Dirceu em reuniões com o marido para tratar de financiamentos para campanhas eleitorais e compra de apoio político.

Podemos observar no Quadro 6 abaixo as funções da personagem Dirceu na matéria:

Quadro 6

\begin{tabular}{|l|l|}
\hline Funções & Ações atribuídas pela revista \\
\hline Acusado de articular o esquema do & "Em depoimento a CPI dos Correios, \\
mensalão & Renilda Santiago Fernandes de Souza, \\
& mulher do publicitário Marcos Valério \\
& disse que José Dirceu não só sabia \\
& de tudo como ainda se reuniu com \\
& representantes dos bancos envolvidos" \\
& (p.57) \\
\hline Frustrado & "O ex-ministro se considerava o \\
& sucessor natural de Lula",p.59 \\
\hline
\end{tabular}




\begin{tabular}{|l|l|}
\hline Arquivo vivo da política & $\begin{array}{l}\text { "Dirceu tem a memória boa e ruim do } \\
\text { governo Lula" p.58 }\end{array}$ \\
\hline Não queria ser acusado sozinho & $\begin{array}{l}\text { "'Fiz tudo com o conhecimento e o aval } \\
\text { do presidente', repete Dirceu, dando a } \\
\text { entender que, para se salvar, não hesitará } \\
\text { em chantagear o presidente Lula", p.58 }\end{array}$ \\
\hline $\begin{array}{l}\text { Ainda era preservado pelos colegas } \\
\text { de partido }\end{array}$ & $\begin{array}{l}\text { "Delúbio (Soares, tesoureiro do PT) } \\
\text { fez questão de preservar Dirceu em } \\
\text { seu depoimento à CPI, dizendo que o } \\
\text { ex-ministro não sabia nadica de nada } \\
\text { dos empréstimos bancários malandros } \\
\text { contraídos pelo PT" (p.58) }\end{array}$ \\
\hline Sentia que poderia ser traído & $\begin{array}{l}\text { "Dirceu não tem dúvidas de que ele é } \\
\text { uma espécie de troféu para a oposição } \\
\text { e que pode ser vítima de uma conspi- } \\
\text { ração de ex-aliados" (p.60) }\end{array}$ \\
\hline $\begin{array}{l}\text { Humilhado pela forma como } \\
\text { foi demitido da Casa Civil }\end{array}$ & $\begin{array}{l}\text { Jefferson em que ele aconselha Dirceu } \\
\text { a deixar o governo, foi chamado ao } \\
\text { gabinete do presidente 'acho melhor } \\
\text { você sair', disse Lula, de maneira } \\
\text { brusca" (p.60). }\end{array}$ \\
\hline
\end{tabular}

A seguir, destacamos as principais características de Dirceu no Quadro 7:

Quadro 7

\begin{tabular}{|l|l|}
\hline Características & Características atribuídas pela revista \\
\hline Físicas & Não aparecem \\
\hline Psicológicas & Pragmático, Ressentido e humilhado \\
\hline Sociais & $\begin{array}{l}\text { Demitido da Casa Civil, prestes a per- } \\
\text { der o mandato de deputado }\end{array}$ \\
\hline Ideológicas & Atende a interesses políticos \\
\hline Morais & $\begin{array}{l}\text { Acusado de chefiar um esquema de } \\
\text { corrupção }\end{array}$ \\
\hline
\end{tabular}

Entendemos que a matéria da edição 1916/2005 pode representar o fechamento do ciclo anti-heróico de José Dirceu nas quatro matérias 
analisadas (outros fatos se sucederam após as primeiras acusações contra Dirceu no escândalo do Mensalão) com o momento da possível vitória ou destruição do personagem.

\section{Considerações finais}

A partir da análise das funções, ações atribuídas e características de José Dirceu em quatro matérias de Veja, encontramos indícios de que, no período analisado, ele cumpre, como personagem da revista Veja, uma saga anti-heróica, tendo em vista que é retratado sob várias nuances, que ressaltam suas contradições inclusive de cunho pessoal e psicológico, e a possibilidade de ser derrotado/destruído.

Ainda que nossos resultados sejam preliminares, é possível inferir que a personagem José Dirceu descrita em Veja é alguém que desperta desconfiança dos que estão a sua volta e se adequou ideologicamente de acordo com o momento político que vivia. Suas principais características psicológicas, que, segundo a revista, se mantiveram desde a ditadura militar, seriam frieza, pragmatismo, capacidade centralizadora e de fazer qualquer coisa para se manter no poder. Ao se descrever o contexto em que o ex-ministro estaria em conflito com os companheiros de partido em função das acusações de envolvimento no Mensalão, Veja descreve, por exemplo, José Dirceu como alguém que não seria amigo de ninguém e que estava em atrito com o então presidente Luiz Inácio Lula da Silva.

Ao mesmo tempo, a revista apropria-se, mesmo que de forma involuntária, das fases atribuídas por Campbell aos heróis das narrativas ficcionais. Se a caracterização e as ações atribuídas reforçam aspectos negativos de Dirceu enquanto personagem de Veja, por outro lado, a associação às fases do herói ajuda a explicar o destaque da revista a Dirceu em diferentes momentos históricos e - por que 
não - o reconhecimento à liderança do ex-ministro enquanto ator político da história recente.

De qualquer maneira, seja para enfatizar características desabonadoras, seja para contar as peripécias e reviravoltas da biografia de Dirceu, ao enfatizar este personagem, Veja reforça a ideia de que o jornalismo, ao reunir e combinar fragmentos da vida real, torna-se ele mesmo o narrador que atribui valor de verdade às narrativas publicadas e importância às personagens políticas da contemporaneidade.

\section{REFERÊNCIAS BIBLIOGRÁFICAS}

ABDALA JUNIOR, B. (1995). Introdução à Analise de Narrativa. São Paulo: Scipione. CAMPBElL, J.O. (1997). Herói de Mil Faces. São Paulo: Cultrix.

GANCHO, C. V. (2002). Como analisar narrativas. São Paulo: Editora Ática.

GUAZINA, L. (2014). "Quando cultura política e subcultura jornalística andam de mãos dadas: a desconfiança na política em tempos de escândalos". Trabalho apresentado no $23^{\circ}$ Encontro Anual da Associação Nacional dos Programas de Pós-Graduação em Comunicação - Compós.

GUAZINA, L.; MOTTA, L. G. (2010). "O Conflito como categoria Estruturante da Narrativa Política: o caso do Jornal Nacional”, in Brazilian Journalism Research, v.6, pp.132-149.

MESQUITA, M. (2003). O quarto Equívoco - o poder dos media na sociedade contemporânea. Coimbra: MinervaCoimbra.

MOTTA, L. G. (2011). Análise Crítica da Narrativa. Brasília: Editora Universidade de Brasília.

MOTTA, L. G. (2011). "A narrativa mediada e a permanência da tradição: percurso de um anti-herói brasileiro", in Estudos de Literatura Contemporânea, n. ${ }^{3}$, julho/dezembro, pp.185-212.

PROPP, V. (2001). Morfologia do Conto Maravilhoso. São Paulo: CopyMarket.com. THOMPSON, J. (2002). O Escândalo Político: poder e visibilidade na era da mídia. Rio de Janeiro: Vozes. 
TUCHMAN, G. (1993). "A Objetividade como Ritual Estratégico: uma análise das noções de objetividade dos jornalistas", in TRAQUINA, N. (Org.). Jornalismo: questões, Teorias e Histórias. Lisboa: Vega, pp. 74-90.

TUCHMAN, G. (1993). "Contando estórias", in TRAQUINA, N. (Org.). Jornalismo: questões, Teorias e Histórias. Lisboa: Vega, pp. 258-262.

TUCHMAN, G. (1978). Making News. A Study in the Construction of Reality. New York: Free Press.

TRAQUINA, N. (Org.) (1993). Jornalismo: questões, Teorias e Histórias. Lisboa: Vega. VEJA, Destruição e Morte: porquê?, edição 5, 1968.

—, O Congresso Interrompido, edição 6, 1968.

—, O homem que faz a cabeça de Lula, edição 1770, 2002.

—, Ele assusta o governo, edição 1916, 2005.

WAISBORD, S. (2000). Watchdog Journalism in South America: news, accountability and democracy. New York: Columbia University Press. 


\title{
CAMINHOS NARRATIVOS: UM PERSONAGEM: O BRASILEIRO
}

\author{
Célia Maria Ladeira Mota \\ Programa de Pós-graduação \\ Faculdade de Comunicação, UnB \\ Leylianne Alves Vieira \\ Programa de Pós-graduação \\ Faculdade de Comunicação, UnB
}

No livro Morfologia do Conto Maravilhoso, o autor, Vladimir Propp (1970), nos dá uma definição simples e clara sobre o personagem e sua função: é o ser que realiza uma ação que é a base da intriga de um conto. Personagem é, assim, o ser humano em movimento, seja na vida pessoal, individual, seja nas narrativas ficcionais ou nos relatos jornalísticos. Sua participação num relato viabiliza detalhes de descrição física ou social e determina a interação com grupos sociais. É a partir da vivência do personagem que os relatos ganham vida e se tornam fonte para os narradores. O ponto de partida para a análise de personagens é, portanto, o mundo da vida, uma expressão que define a experiência vivida.

Neste artigo, analisamos a caracterização de um personagem como é concebida em dois gêneros narrativos: o ficcional e o jornalístico. Vamos observar como o brasileiro é representado em Macunaíma, 
na obra de Mário de Andrade, e na reportagem da revista Realidade "O canavial esmaga o homem", que conta a saga de Gregório, um trabalhador de engenho. $\mathrm{O}$ foco é perceber as subjetividades dos relatos e os contrastes entre a fantasia e a realidade e compreender os significados construídos. São representações da identidade do brasileiro que têm sua origem em duas matrizes culturais que herdamos dos portugueses: a aventura e o trabalho.

O caminho teórico é o da Análise Crítica da Narrativa, como proposta por Motta, para quem "esta análise é um caminho rumo ao significado e o significado é uma relação: não há significado sem algum tipo de troca (Motta, 2013: 121). Investigando as jornadas dos dois personagens e os acontecimentos nos quais se envolvem, de acordo com o ciclo do herói proposto por Campbell (2007), a análise estuda os significados que emergem de práticas culturais que têm raízes históricas e que até hoje contribuem para uma certa ambiguidade na concepção do personagem brasileiro.

\title{
O personagem: um ator?
}

\begin{abstract}
A vida nada mais é do que uma sombra, um pobre ator que se pavoneia no palco, e então não é mais ouvido. É uma estória contada por um idiota, cheia de som e fúria, que significa nada. (Shakespeare, em Macbeth).
\end{abstract}

Ao se basear em personagens fictícios que reproduzem as relações de poder e as intrigas de cortes europeias do século XVII, Shakespeare coloca considerações filosóficas nas falas dos atores. Seus textos se dividem entre relatos de acontecimentos trágicos e falas, monólogos e diálogos, que buscam oferecer um significado para os fatos. Para Shakespeare, o drama, cheio de som e fúria, terminava quase sempre com a morte. Suas concepções lembram Platão que, 
muitos anos antes, afirmara ser a obra dramática uma arte ilusória que refletia o mundo de aparências à sua volta. O poeta, dizia Platão, com sua arte ilusória diz o falso como verdade. Para Platão, por não imitar a ideia, mas a aparência sensível, a criação mimética opera por ilusões e se torna degradante. O termo grego mímesis tem sido geralmente traduzido por 'imitar', e, por isso, nos termos de Platão, o drama seria uma imitação pobre da realidade. O conceito dividiu dois sistemas filosóficos gregos, o platônico e o aristotélico: seria a mímesis uma simples cópia da realidade ou uma reapresentação deste mundo exterior? Cópia ou imitação criativa?

Ricoeur (1994) nega a imitação e afirma que a narrativa é uma releitura da vida, uma cópia criativa em torno de novos significados. Seguindo Aristóteles em sua Arte Poética, o autor francês considera que o objeto da mímesis é a ação humana e, assim, incorpora diferentes interpretações do real. Este ponto de vista adota a ideia de verossimilhança entre seres ficcionais e o ser humano real, lembrando Aristóteles que afirmava ser o objeto da poiesis imitar os humanos em ação, fosse por uma narrativa dramática ou trágica, ou por uma comédia. A mímesis corresponderia a uma atividade do imaginário sobre o real, que, além de proporcionar prazer, também produz saber. Como afirmou Aristóteles, "é mister ater-se sempre à verossimilhança, de modo que o personagem, em suas palavras e ações, esteja em conformidade com o necessário e verossímil" (apud Ricoeur, 1994). Com isso, o filósofo grego acreditava que a obra poética não era uma simples cópia da aparência, mas uma criação sobre a vida real.

Esta criação se realiza a partir de procedimentos que relacionam a realidade e a ficção. Para Aristóteles, a comédia e a tragédia eram artes a imitar as ações humanas e o faziam pela linguagem, pelas ações boas ou ruins e a construção narrativa (se drama ou comédia). Esta liberdade criativa trabalha com os limites da verossimilhança, ou seja, a obra ficcional tem de se basear em características e personagens do mundo real que sejam verossímeis, críveis. 
O personagem, de acordo com o papel que desempenha no enredo, pode ser protagonista, antagonista ou um personagem secundário, figurante (Gancho, 1991: 14-16). Quanto às descrições física e psicológica, os personagens podem ser planos ou redondos. Os primeiros são aqueles "[...] caracterizados com um número pequeno de atributos, que os identifica facilmente perante o leitor; de um modo geral são personagens pouco complexos" (Gancho, 1991:16). Os mesmos podem ser caricaturas ou tipos. Já os personagens redondos são aqueles mais complexos, dispondo de uma variedade maior de características: podem ser físicas, psicológicas, sociais, ideológicas ou morais, de acordo com a autora. Personagem, no campo da literatura, é o ser ficcional responsável pelo desenrolar do enredo. É considerado uma invenção, uma construção literária, ou um 'ser de papel'. Entretanto, negar a relação entre personagem e pessoa real seria absurdo: os personagens representam pessoas, como acontece nas narrativas jornalísticas. Nestas, seres humanos reais se envolvem em acontecimentos que mudam a rotina de vida, são transformadores em maior ou menor grau e criam novos significados para as ações sociais. Estas transformações operam tanto nas narrativas ficcionais ou nas fáticas pela linguagem, que é um processo de representação do real.

\section{A representação}

A tragédia só imita a realidade porque a recria através de um mythos, de uma fábula, que atinge sua mais profunda essência. (Ricoeur, 1994).

Como processo, a representação é um trabalho ativo, que implica selecionar signos, códigos, fazê-los interagir, e é a partir desta prática que atribuímos valores e significados às nossas práticas sociais. Como lembra Montoro, a representação é uma prática concreta de 
significação. "O trabalho de uma prática representacional consiste em tentar fixar os significados, na tentativa de privilegiar um ponto de vista" (Montoro, 2006: 22).

Mas se a representação tende a fixar significados, estes sofrem um processo de negociação na medida em que o texto interage com a experiência cultural e pessoal do leitor. Foi Barthes quem primeiro estabeleceu um modelo sistemático pelo qual se poderia analisar este processo de negociação de significados. Para ele, existem duas ordens de significação. A primeira é a denotação e descreve a relação entre significante e significado no interior do signo e do signo com o seu referente na realidade externa. A denotação é o sentido primeiro e mais óbvio de um texto, seja ele escrito, falado ou imagético, em filme ou fotografia.

A segunda ordem de significação é a conotação. Segundo Barthes (1971), ela descreve a interação que ocorre quando o signo encontra os sentimentos e emoções dos usuários, assim como os valores da sua cultura. Barthes afirma que numa fotografia a diferença entre conotação e denotação é clara. A denotação é a reprodução mecânica no filme de um objeto para o qual a câmera aponta. Já a conotação é a parte humana do processo; é a seleção do que incluir no enquadramento, que foco, que ângulo de câmera, que tipo de filme usar, se colorido ou preto e branco. Denotação é o que é fotografado. Conotação é como é fotografado.

Outro conceito que, segundo Barthes, explica como o signo trabalha é o de mito. Um mito é uma estória ou narrativa pela qual uma cultura explica ou compreende algum aspecto da realidade ou da natureza. Os mitos primitivos falavam de vida e morte, homens e deuses, o bem e o mal. Já os mitos modernos tentam explicar a masculinidade e a feminilidade, a família, a ciência. Barthes pensa no mito como uma cadeia de conceitos relacionados. Se a conotação é a segunda ordem de significante, o mito é a segunda ordem do significado. O mito é o significado cultural que é ativado pelo signo, mas que pré-existe ao 
signo. Atualmente, um mito frequente nos relatos fílmicos é a construção do personagem como uma epopeia de herói. Um mito que está presente também em algumas narrativas jornalísticas.

O herói e sua jornada vêm a ser o que o antropólogo Joseph Campbell chamou de monomito, um conceito que explica como o personagem percorre um ciclo completo para cumprir uma missão ou tarefa. Como conceito de Narratologia, o termo apareceu pela primeira vez em 1949, no livro de Campbell O Herói de Mil Faces. Campbell descreve as narrativas de Gautama Buddha, Moisés e Cristo em termos de monomito e afirma que mitos clássicos de muitas culturas seguem um padrão básico. Campbell define este padrão narrativo como a Jornada do Herói (2007), cujos estágios são:

Mundo Comum - o mundo normal do herói antes da história começar;

- O Chamado da Aventura - um problema se apresenta ao herói: um desafio ou a aventura;

- Reticência do Herói ou Recusa do Chamado - o herói recusa ou demora a aceitar o desafio ou aventura, geralmente porque tem medo;

- Encontro com o mentor ou Ajuda Sobrenatural;

- Cruzamento do Primeiro Portal - o herói abandona o mundo comum para entrar no mundo especial ou mágico;

- Provações, aliados e inimigos;

- Aproximação - o herói tem êxitos durante as provações;

- Provação difícil ou traumática - a maior crise da aventura, de vida ou morte;

- Recompensa - o herói enfrentou a morte, se sobrepõe ao seu medo e agora ganha uma recompensa;

- O Caminho de Volta - o herói deve voltar para o mundo comum.

A força dramática de um enredo está na busca de realização de um desejo do personagem, herói ou não, e na oposição das forças 
de antagonismo que dificultam ou impedem que ele alcance aquilo que quer. Na análise, o ponto de partida é caracterizar o protagonista da história, considerando as relações que mantém com outros personagens. Todos têm a função, no enredo, de criar fios narrativos que movimentam a intriga. O protagonista é o personagem mais bem desenvolvido na história. Ele é o centro nervoso da trama que sustenta o eixo narrativo. Todos os eventos, personagens e elementos da história giram ao seu redor. Já o antagonista é o personagem (que pode também ser um objeto, animal, monstro, espírito, instituição, grupo social, limitação de ordem física, psicológica, social ou cultural) que traz ou representa uma ameaça, obstáculo, dificuldade ou impedimento ao que o protagonista deseja conquistar. Muitas vezes, o protagonista pode ser levado pelos acontecimentos, como se estes fossem a mão do destino.

\section{$O$ acontecimento e a narrativa}

O acontecimento é da ordem do inesperado, do novo ou do inédito, e introduz uma descontinuidade, reportando-se à noção fenomenológica do presente, como "o hoje em função do qual há um amanhã e um ontem” (Ricoeur, 2014: 158)

Como lembra a pesquisadora Vera Veiga França, da UFMG, o acontecimento é um conceito que tem presença importante nos campos da história e da filosofia, mas só recentemente ele vem ocupando espaço nos estudos de Comunicação, especialmente na Teoria do Jornalismo, em que aparece como sinônimo do fato ou para distinguir a noticiabilidade de ocorrências do cotidiano. Uma linha mais recente de pesquisa vem abordando o acontecimento como uma transformação que ocorre no domínio da experiência humana e que tem a capacidade de interferir no quadro da normalidade. 
É "a ocorrência desencadeadora de sentidos" (Quéré, 2012) cuja complexidade extrapola a narrativa factual ou jornalística.

Ao desorganizar o presente, o acontecimento instala uma temporalidade estendida, convoca um passado com o qual possa estabelecer ligações, anuncia futuros possíveis... Ele nos serve para perceber a ruptura, o alcance, a potencialidade, enfim, abertos por certos fatos. (França, 2012: 48).

O Jornalismo vive no ritmo dos acontecimentos, que nos permitem ler o mundo a partir dos fatos e dos sentidos que eles desencadeiam. Como Adriano Rodrigues costuma afirmar, "é acontecimento tudo aquilo que irrompe na superfície lisa da história dentre uma diversidade aleatória de fatos virtuais" (Rodrigues, 1993: 27). Os acontecimentos vão sendo construídos pela linguagem, pela narrativa factual e também pela narrativa ficcional, que nos fornecem uma dimensão simbólica, de significação nova sobre o real. "Produzem a compreensão de um estado de coisas reconstituídas em tramas e narrativas, nas quais aparecem os atores que desempenham papéis" (Quéré, 2012: 68).

É importante a distinção que Sodré faz entre fato e acontecimento (Sodré, 2009: 33). Enquanto o acontecimento se pauta pela atualidade, o fato, mesmo inscrito na história, é uma elaboração intelectual. Por sua vez, Mouillaud afirma que "o acontecimento é a sombra projetada de um conceito construído pelo sistema da informação, o conceito do fato" (Mouillaud, 2012: 51). Assim, a informação jornalística parte de objetos tidos primeiro como factuais para obter, por intermédio do acontecimento, alguma clareza sobre o fato social e histórico. "É, portanto, uma atividade que transcende a mera distribuição de relatos sobre a realidade. Visto como uma narrativa, o relato jornalístico envolve enredos, conflitos e personagens para se desenvolver" (Mota, 2012: 16). 
Para uma maior compreensão desta concepção, um bom exemplo de meta-acontecimento é o "11 de setembro". Para além das imagens televisivas que noticiaram a ocorrência, é o próprio discurso do fato que emerge como notável. Os eventos desencadearam enormes dimensões sociais e políticas que ainda não se esgotaram. $\mathrm{O}$ "11 de setembro" se tornou tema de memória coletiva, a ser relembrado a cada ano, transformado em efeméride pela grande mídia, o que contribui para atualizar e desdobrar os sentidos, conferindo uma maior compreensão do ocorrido.

A concepção de acontecimento para além da narrativa jornalística e mesmo da narrativa ficcional permite perceber sua abrangência como transformação da vida de muitas pessoas envolvidas, das mortes ocorridas, e do seu poder de continuar provocando sentidos novos em outras ocorrências. Outro exemplo claro do conceito foi a catástrofe conhecida como tsunami, que atingiu o sudeste da Ásia em 2004, e que ficou para sempre na memória coletiva não só dos povos asiáticos, mas de toda a humanidade. O acontecimento tem, nesta perspetiva, um antes e um depois do fato que se tornou conhecido pelas narrativas midiáticas. Ele será lembrado por muitos anos não só pelos que viveram a tragédia daqueles dias, mas por todos os que possam temer sua repetição.

É, portanto, pela vivência de acontecimentos grandes ou triviais que se estabelecem as interações sociais, expondo identidades e deslocando os participantes do fato para as funções de protagonistas ou antagonistas nas narrativas que se seguirão. $\mathrm{O}$ acontecimento tem relação direta com os personagens envolvidos numa experiência. Como destaca Quéré, "o verdadeiro acontecimento não é unicamente da ordem do que ocorre, do que se passa e se produz, mas também do que acontece a alguém" (Quéré, 2005: 61). Ou seja, o acontecimento é um fenômeno que afeta e transforma aqueles que o vivem. É o que resulta da própria transformação dos sujeitos. E, em consequência, da própria transformação da comunidade a que pertence o indivíduo, 
permitindo que novos significados sejam partilhados. É pelo acontecimento que a narrativa instala os conflitos entre os personagens.

\title{
Narrativas e significações
}

\author{
Narrar é uma forma de dar sentido à vida. Na verdade, as \\ narrativas são mais que representações: são estruturas que \\ preenchem de sentido a experiência e instituem significação \\ à vida humana. Narrando, construímos nosso passado, nosso \\ presente e nosso futuro. (Motta, 2013: 18).
}

Duas narrativas fazem parte do material empírico selecionado para a análise da construção de significados a partir dos personagens e dos acontecimentos em que se envolvem. A primeira narrativa é ficcional e trata de um personagem que foi concebido nos primeiros anos do século $\mathrm{XX}$, quando começa a se forjar a ideologia de um Brasil fruto de uma mestiçagem de três raças. Macunaíma, de Mário de Andrade, é o personagem ficcional onde vamos procurar compreender os traços de brasilidade pela análise da narrativa. O segundo texto a ser analisado nos apresenta um personagem de um relato jornalístico, baseado num ser real, também fruto da selva, o trabalhador do canavial. A reportagem analisada é "O canavial esmaga o homem", da antiga revista Realidade. Qual dos dois se assemelha mais ao personagem de que fala Campbell, ao descrever as jornadas de busca e realização que consagram os heróis?

A análise crítica da narrativa supõe três planos: plano da expressão, plano da história ou estória e plano da meta-narrativa. O plano da expressão é o plano da linguagem, o da superfície do texto, por meio do qual o enunciado é construído pelo narrador. Tanto para o texto ficcional como para o factual, a análise textual permite examinar figuras de linguagem, caminhos de representação de personagens 
e de suas ações, e recursos narrativos que ajudam a perceber a intencionalidade do narrador e suas estratégias persuasivas. É neste plano também que se identificam os protagonistas e antagonistas, as situações de conflito e as intrigas que permitem a evolução das ações. Nesta análise privilegiamos as representações dos personagens, de que forma são descritos e apresentados pelo texto.

O plano da estória, ou da história como preferem alguns, é o plano da significação ou do conteúdo propriamente dito. Neste plano, a mimese, como a define Ricoeur (1994), permite representar acontecimentos e fatos da vida do personagem, situações em que ele se envolve, numa operação textual de imitação criativa da vida real no caso de narrativa fática, ou da vida imaginada, no caso da narrativa ficcional. Estes acontecimentos revelam os significados que os personagens constroem sobre si mesmos, a partir da atividade criativa do narrador.

O terceiro plano da meta-narrativa, conforme acentua Motta, é o plano da estrutura profunda, que evoca imaginários culturais. É o conflito que tece a trama através do relato de incidentes, rupturas, descontinuidades. A meta-narrativa é quase sempre não dita, mas contradita. É uma verdade ou um imaginário que se constrói em torno de um tema e que volta à memória sempre que o tema se torna objeto de algum relato, especialmente jornalístico. A meta-narrativa se vale de acontecimentos anteriores, que provocaram significados diferentes, de fundo cultural, para retomar estes sentidos em novo texto. A análise da meta-narrativa é um movimento de sair do texto, do plano da expressão, para buscar os fios narrativos que trazem os sentidos que se fixaram na memória coletiva.

$\mathrm{Na}$ ficção, como no relato jornalístico, a análise da meta-narrativa permite res-significar os novos acontecimentos à luz de fatos anteriores. Para os que seguem o antropólogo Joseph Campbell, o plano da meta-narrativa permite analisar as jornadas de um herói, tendo como pano de fundo as oposições entre o bem e o mal, a vida 
e a morte, diferentes valores culturais presentes em comunidades diversas, além dos mitos em geral.

Nesta análise, os dois personagens serão examinados a partir de uma perspetiva de identidade e a construção de brasilidade de cada um deles, levando em conta os cenários onde os acontecimentos descritos ocorrem, ficcionais ou reais, e o tempo histórico em que suas estórias são narradas.

\section{Macunaíma: herói da brasilidade}

No caminho pelo Araguaia o exército de passarinhos saúda o herói, que volta a assumir o título de Imperador do Mato-Virgem. Um dia um homem passou pelo Uraricoera, agora uma terra desabitada. Uma voz chegou aos seus ouvidos. Tratava-se do aruaí para quem Macunaíma contara sua história. A ave reproduziu toda essa saga para o viajante e depois partiu para Lisboa. O ouvinte era o escritor, Mário de Andrade, que retratou essas aventuras nesse livro. (Epílogo de Macunaíma, 2008).

Com o romance O Guarani, de José de Alencar, a brasilidade se tornou, pela primeira vez, tema da literatura brasileira, quando o movimento romântico construiu um ser nacional fruto da união entre índios e brancos, deixando o negro naquele momento identificado apenas com a força de trabalho e, portanto, sem direito à cidadania. Foi a partir do movimento abolicionista e das transformações sociais e políticas por que passava o Brasil no começo do século XX que o negro seria integrado às preocupações nacionais e se tornaria personagem de uma literatura mais realista. É nesse momento também que surge o mito das três raças, uma epopeia de um Brasil-cadinho que é forjado nas selvas tropicais.

Como nas sociedades primitivas, o mito é cosmológico, no entender de Ortiz (1987: 38) que o considera a origem do moderno Estado 
brasileiro, ponto de partida de uma visão mítica que antecede a própria realidade. A partir das primeiras décadas do século XX, o Brasil passa de uma economia escravagista para outra de tipo capitalista, saindo ainda de uma organização política monárquica para a adoção do sistema republicano. Começa um processo de industrialização e urbanização, novas cidades surgem e uma classe média se desenvolve. O Brasil entra na era moderna. Se o modernismo é considerado por muitos como um ponto de referência, é porque "este movimento cultural trouxe consigo uma consciência histórica que até então se encontrava de maneira esparsa na sociedade" (Ortiz, 1987: 40). É naquele momento que Gilberto Freyre reedita a temática racial para constituí-la em objeto privilegiado de estudo, uma chave para a compreensão do Brasil. Freyre transforma a negatividade do mestiço, afirmada até então, em uma positividade que vai redesenhar os contornos da identidade brasileira. "O que era mestiço torna-se nacional", na expressão usada por Ortiz. Os modernistas do século XX propõem devorar a cultura europeia, numa antropofagia cultural que busca acabar com a importação de práticas artísticas e literárias da velha Europa. "Esta postura vai permitir aos modernistas a busca de expressão da brasilidade, pintando o homem brasileiro das cidades e do sertão, assim como as paisagens proletárias de São Paulo" (Mota, 2014:10).

Um personagem surge então naquele caldo de cultura. Aproximando o folclore, os rituais populares e as lendas indígenas, Mário de Andrade, paulista, culto e viajado, concebe Macunaíma, um ser da floresta primitiva e que vai morar na cidade grande, experimentando a contradição que significava viver no Brasil em 1930. No texto, etnia e cultura aparecem como sinônimos e, às vezes, como antônimos. Em Macunaíma, Mário de Andrade proclama a síntese nacional, isto é, a presença frente a frente das três etnias que formam o povo brasileiro. Macunaíma surge, assim, como um personagem que vai ser objeto de uma inclusão cultural precoce para a época, um retrato do brasileiro que mistura qualidades e defeitos e experimenta de tudo um pouco. 
Em 17 capítulos, o livro apresenta a saga de um brasileiro que descobre o Brasil, suas crenças e ideias, numa aventura mista de jornada de herói, como a define Campbell. Macunaíma nasce e já manifesta sua principal característica: a preguiça. O herói vive às margens do mítico rio Uraricoera com sua mãe e seus irmãos, Maanape e Jiguê, numa tribo amazônica. Após a morte da mãe, os três irmãos partem em busca de aventuras. Macunaíma encontra Ci, Mãe do Mato, rainha das Icamiabas. Depois de dominá-la, com a ajuda dos irmãos, faz dela sua mulher, tornando-se assim imperador do Mato Virgem.

O herói tem um filho com Ci e esse morre, ela morre também e é transformada em estrela. Antes de morrer dá a Macunaíma um amuleto, a muiraquitã (pedra verde em forma de sáurio), que ele perde e que vai parar nas mãos do mascate peruano Venceslau Pietro Pietra, o gigante Piaimã, comedor de gente. Como o gigante mora em São Paulo, Macunaíma e seus irmãos vão para lá, na tentativa de recuperar a muiraquitã. Após falhar com o plano de se vestir de francesa para seduzir o gigante e recuperar a pedra, Macunaíma foge para o Rio de Janeiro. Lá encontra Vei, a deusa sol, e promete casamento a uma de suas filhas, mas namora uma portuguesa e enfurece a deusa. Depois de muitas aventuras por todo o Brasil, na tentativa de reaver a sua pedra, o herói a resgata e regressa para a sua tribo. Ao fim da narrativa, vem a vingança de Vei: ela manda um forte calor, que estimula a sensualidade do herói e o lança nos braços de uma uiara traiçoeira, que o mutila e faz com que ele perca de novo - dessa vez irremediavelmente - a muiraquitã. Cansado de tudo, Macunaíma vai para o céu transformado na Constelação da Ursa Maior.

Como o próprio Mário declarou, ele teve muitas intenções ao escrever Macunaíma, tratando de diversos problemas brasileiros: a falta de definição de um caráter nacional, a cultura submissa e dividida do Brasil, o descaso para com as nossas tradições, a importação de modelos socioculturais e econômicos, a partir de uma visão antropofágica em moda na década de 1930. Uma preocupação de 
Mário de Andrade parece evidente: buscar uma identidade cultural brasileira. Esta cultura nacional seria formada pelas diversas culturas populares existentes. Na visão de Mário de Andrade, o Brasil englobaria numa só as representações culturais das regiões do país. Por isso Macunaima vive lendas, folclores, costumes, falares diversos e mistura crenças religiosas, como explica o escritor:

Um dos meus interesses foi desrespeitar lendariamente a geografia e a fauna e flora geográficas. Assim desregionalizava o mais possível a criação ao mesmo tempo que conseguia o mérito de conceber literariamente o Brasil como entidade homogênea - um conceito étnico nacional e geográfico (Andrade, 2008).

A narrativa é construída na terceira pessoa pelo narrador, o próprio escritor. A história se passa no século $\mathrm{XX}$, mas o tempo mítico predomina, pois, os mitos e lendas não se enquadram na cronologia tradicional. Este espaço mítico é reforçado pelas mudanças de cenário da narrativa, que transporta Macunaíma para várias regiões do país num piscar de olhos. Da selva amazônica sai para São Paulo, onde descobre as máquinas. As palavras iniciais da trama já tentam construir um perfil sociológico do personagem: 'Macunaíma nasceu negro e feio. Foi parido pela índia Tapanhumas no rio Uraricoera. Ele permaneceu seis anos sem falar, por pura preguiça. Se o incitavam a falar exclamava: - Ai! Que preguiça!... e não dizia mais nada'. Ao completar seis anos, o herói ganhou água em um chocalho e a partir daí passou a falar sem problemas. Foi para a mata e virou príncipe. Na maioridade, Macunaíma teve uma ideia. Ele iludiu sua mãe, pediu que ela cerrasse os olhos e, quando ela os abriu de novo, os dois estavam na outra margem do rio, rodeados de alimentos fartos. Mas a índia quis levar uma parte da refeição para os outros filhos. O protagonista ficou com raiva e os transportou mais uma vez para a velha casa. Voltaram a sentir fome. 
No capítulo dois, o autor oferece uma primeira representação de Macunaíma como brasileiro. O texto fala que a avó do menino pegou uma gamela cheia de caldo envenenado de aipim e jogou a lavagem no piá. Macunaíma se afastou, mas só conseguiu livrar a cabeça, todo o resto do corpo se molhou. "Porém a cabeça não molhada ficou prá sempre rombuda e com carinha enjoativa de piá". Para o escritor, o episódio caracteriza o personagem como uma representação do país, um gigante que ainda pensa como criança. Da Mãe do Mato, Macunaíma ganha um muiraquitã, uma pedra verde. É seu talismã que perde e vai procurar em São Paulo. Antes da viagem, a primeira metamorfose: ele toma banho em uma água mágica e sua pele fica branca, os olhos azuis e os cabelos loiros. Seu irmão tenta se banhar na mesma água, mas só consegue um tom de bronze para a pele. Mais uma representação simbólica da mistura de etnias do brasileiro que produz uma grande variedade de cores de pele.

Em São Paulo, o herói encontra seu antagonista, o gigante Piaimã, encarnação do mercador peruano Pietro Pietra, que havia roubado seu muiraquitã. Piaimã come as pessoas e vive com a Caapora, mais uma lenda incorporada à narrativa. Para se livrar do gigante, Macunaíma vai para o Rio de Janeiro, onde frequenta a macumba da Tia Ciata. Nos capítulos seguintes, Macunaíma inventa histórias de caçadas fartas ao se frustrar em uma tentativa de apanhar uma caça melhor no Bosque da Saúde. Todos descobrem a mentira, confessada por ele mesmo. Então ele vai pescar no Tietê e cai na rede de Ceiuci, esposa de Piaimã. Ele é deixado na sala da casa do gigante enquanto a mulher vai preparar tudo para assá-lo. Mas a filha caçula de Ceiuci o encontra e o esconde no quarto dela, onde os dois começam a brincar. No fim da história ele teve de fugir da mãe. Nessa fuga passa por inúmeras aventuras e por boa parte do país. No fim o tuiuiú virou avião e o trouxe de volta para São Paulo. A filha caçula do gigante se transforma em cometa. 
Tanto no plano da expressão como no plano da estória, o livro envolve o personagem no universo mítico do Brasil, usando não só nomes indígenas como cenas de caçadas no mato e alimentos típicos de várias regiões. No plano da meta-narrativa, a representação de Macunaíma tem sido interpretada como símbolo do homem brasileiro, que teria sua natureza psicológico-cultural identificada no subtítulo dado ao livro: 'sem nenhum caráter'. Para alguns autores, a expressão significaria apenas 'sem características próprias', sem identidade definida, como, ao que parece, era a ideia de Mário de Andrade. Se de um lado há uma imagem de 'mau-caráter', pelas travessuras e brigas em que Macunaíma se mete, por outro há uma leitura do personagem como 'matreiro, esperto, um brasileiro que sempre tem seu jeitinho'. Um malandro ou um herói?

Como define Da Matta, o malandro é aquele que escolhe ficar no meio do caminho juntando, de modo quase sempre humano, a lei impessoal e a amizade e a relação pessoal. Esta malandragem parece caracterizar o personagem Macunaíma, que é capaz de proezas incríveis e aventuras míticas, mulherengo e preguiçoso, mas que vence o gigante adversário ao final e recupera sua pedra mágica, a muiraquitã. Viajante da floresta para a cidade grande, dando um jeito de sobreviver em ambas, Macunaíma não tem apenas o gosto da trapaça, mas revela um jeito de ser e de sobreviver que caracteriza o brasileiro, que vive num sistema em que a casa nem sempre fala com a rua e as leis formais da vida pública nada têm a ver com as boas regras da moralidade costumeira. "Num mundo tão profundamente dividido, a malandragem e o 'jeitinho' promovem uma esperança de tudo juntar numa totalidade harmoniosa e concreta. Antes de ser um acidente ou mero aspecto da vida social brasileira, coisa sem consequência, a malandragem é um modo possível de ser" (Da Matta, 1986: 105). 


\section{O herói invisível}

Farofa, taquinho de carne há 54 anos. É só. Asneira dizer que come. A gente enche a barriga, mas a danada da fome volta logo. Sou cabra bom. Não tenho vexame de dizer (Gregório, in: Realidade, 1970).

Nem jeitinho, nem ritual mágico e nem a ajuda da Mãe do Mato foram capazes de encher de comida o prato de Gregório. Não há milagres na história de um personagem real, um brasileiro como tantos outros, lutando para sobreviver em condições precárias. Com 54 anos e apenas três dentes, Gregório é o personagem principal da reportagem "O canavial esmaga o homem”, tema da edição 46 da revista Realidade, em janeiro de 1970. A reportagem faz parte de uma série de artigos da revista, publicada entre 1969 e 1973, que retratou os brasileiros de diferentes rincões do Brasil. Estes brasileiros foram os personagens reais, embora invisíveis, de narrativas construídas durante os anos de milagre econômico da ditadura militar.

Utilizando técnicas literárias, os repórteres Jorge Andrade e Jean Solari são os narradores de um texto que destaca a pobreza, a dificuldade para obter alimentos, a incerteza sobre o futuro, recriando a realidade de um Brasil pouco conhecido naquele momento histórico e que, para muitos, continua invisível até hoje. Eles viajaram para o estado do Pernambuco em busca dos engenhos de rapadura, dos canaviais e dos homens que são os responsáveis por manterem o canavial em atividade: o trabalhador do engenho. O canavial é apresentado ao leitor como um personagem vivo, que vai tomando os espaços naturais, crescendo muito rapidamente e modificando a paisagem. A cana também é dotada de armas naturais, que maltratam os trabalhadores de engenho: as folhas são como navalhas.

No plano de expressão da narrativa o canavial é representado como um mar verde que aprisiona homens, mulheres, crianças e 
idosos. Quem olha a partir de um prisma externo, enxerga apenas as folhas que se mexem com o vento. Quem está ali dentro vê a sua própria história ligada ao canavial. Podemos observar isso quando o narrador nos apresenta o personagem principal desta narrativa, Gregório. Assim mesmo, sem sobrenome. Um homem humilde, analfabeto, envelhecido, que se levanta todos os dias às três horas da madrugada, pega suas armas e vai para o canavial. É lá que busca o sustento, a paga que permitirá o acesso ao alimento.

O canavial passa a ser descrito como o antagonista, devido aos riscos que significa para os trabalhadores. Ele representa o perigo que o herói vai ter de enfrentar na luta diária. Além da própria cana, que solta pelos que entram na pele como espinhos, também existem perigos naturais, como é o caso das cobras escondidas nas touceiras de cana. Se os espinhos são a representação de um obstáculo conhecido, as cobras são o perigo desconhecido, porque o homem não tem como prever onde elas estão ou quando o atacarão.

A construção do ambiente pela narrativa inclui os elementos naturais da região e até os sons que inundam o local. Após relatar que a cana expulsou todos os animais, ocupou espaços que antes eram tomados por outra vegetação e incluiu os ambientes de convívio do homem, uma frase descreve o cenário da região: ali "há um mar verde que, quando ondula batido pelo vento, produz um som seco e áspero" (Andrade, 1970: 34). Após a apresentação do espaço físico, tomado pelo canavial, a narrativa se dedica ao personagem, Gregório, descrito como um ser humano que gosta de sonhar.

A narrativa introduz Gregório durante a madrugada, com ele ainda deitado. O narrador mescla as informações referentes ao canavial com dados que traçam as características físicas e sociais daquele espaço. "Na noite que custava a passar, Gregório olhou à sua volta, medindo as paredes do quarto: 3 por 2 metros" (Andrade, 1970: 34). Neste quarto dormem Gregório, sua mulher Dalvanise, Matilde e Madalena, filhas pequenas. Na sala ainda dormem Severino e Joaquim, também 
filhos. Gregório teve sete filhos, dos quais cinco ainda moram com ele. Quanto às crianças, o mais velho daqueles já foi convocado a trabalhar como adulto no canavial:

\begin{abstract}
Severino, de oito anos, não ia ao corte de cana naquele dia: estava com o peito cheio. Cabrinha macho, esse! Com a ajuda dele, tinha cortado tonelada e meia de cana por dia durante a semana. Gregório sentiu frio e encolheu o corpo: acha que é falta de sangue. É por isso que o corpo não se esquenta (Andrade, 1970: 34).
\end{abstract}

Ao sair para trabalhar, Gregório pensa na semana seguinte, quando será lua cheia. Durante estes períodos, quando a noite é bem iluminada, os homens trabalham por mais tempo, recebem mais dinheiro. A narrativa introduz o imaginário do personagem, informando que é pensando em um presente para Dalvanise que ele dá início a sua caminhada de oito quilômetros até o local do corte da cana. Caminhando, ele reflete sobre a influência do canavial sobre a vida de todos, até dos que ali não residem. O texto busca elementos que equiparem o trabalhador à cana. Após um dia de trabalho, ambos tornam-se bagaço, restos. O dono do engenho é representado apenas pelo seu carro. Assim como as máquinas do engenho, a 'máquina' do dono causa emoções positivas ao trabalhador. Ao ver o carro, o texto reforça o imaginário do personagem, que se lembra do pagamento no dia seguinte. Na jornada do herói é um dia especial, porque é sempre seguido por uma visita ao bar para aliviar a tensão do dia a dia e esquecer as dificuldades da vida.

Não são homens, mulheres e crianças vivendo onde gostariam. Estão ali porque não têm outra condição de trabalho. A alimentação não corresponde ao esforço que despendem: a farofa e o 'taquinho' de bacalhau mal dão para se manterem 
de pé. Aguentam-se porque comem a própria cana, que é rica em glicose e sacarose (Andrade, 1970: 37).

A narrativa jornalística usa recursos metafóricos, falando em luta, combate, para dramatizar a vida das pessoas, que estão presas a um destino no qual o caminho é sempre o mesmo: ir para o canavial durante a madrugada e voltar de lá no final da tarde. O canavial é queimado com o intuito de tornar o corte da cana menos perigoso. Em meio a todas as dificuldades do ambiente e do contexto, o que sufoca e faz o homem chorar é a fumaça. Por ser forte e corajoso, não admite para si mesmo reclamar daquele estilo de vida. Mas o corpo fala mais alto, no momento em que o força a chorar em meio à fumaça. É a forma que o sofrimento usa para se expressar. O corpo reclama, expressa os sentimentos do homem, que não consegue verbalizá-los por medo de mostrar fraqueza. Com toda a dificuldade, o personagem cumpre a sua jornada e chega ao alto do morro, vence a batalha diária, derrota o canavial, consegue seu objetivo inicial. Apesar de ganhar aquela batalha, o homem arqueja, está 'morto', porém de cansaço. Ambos estão mortos, o homem e a cana, cada um a sua maneira. E o herói volta a casa para recomeçar tudo outra vez no dia seguinte.

A partir da estrutura do texto, seguindo o personagem ao longo de um dia de trabalho, os repórteres levam para perto do leitor a imagem do trabalhador do engenho. A humanização do personagem permite que o leitor se identifique com ele, compreenda suas aflições e compartilhe o cenário no qual acontecem as cenas da luta. A reportagem da revista Realidade apresenta sem retoques a dura vida dos trabalhadores do canavial, esmagados por problemas como falta de educação, de saúde, explorados como mão de obra barata, vivendo no limite da sobrevivência. São personagens invisíveis recuperados pela revista Realidade para relatar como viviam milhões de brasileiros naquele momento histórico em que o milagre econômico mostrava um país em desenvolvimento que não incluía todos os seus cidadãos. 
A perspetiva adotada aqui é a de encarar o trabalho da revista Realidade, como da mídia jornalística em geral, como uma prática de memória, conforme propõe Babo-Lança (2012) que estuda as relações entre o acontecimento narrado na mídia e a memória coletiva. No caso da reportagem da revista Realidade aqui analisada, temos um exercício de memória a partir do acontecimento jornalístico que, embora narrado em 1970, se constituiu como um documento histórico, e, por isso, detém um duplo valor, de inscrição e de narrativa que reconstrói o passado. Ao reavivar a memória, o texto reapresenta os significados construídos nos idos de 1970 e permite reavaliar sua importância para o presente e para a busca da compreensão do personagem em estudo, o brasileiro, incorporando-o a uma meta-narrativa cultural que tem raízes profundas.

\section{Considerações finais}

Ao colocar em confronto duas narrativas, a ficcional, apresentando Macunaíma como uma síntese do caráter do brasileiro, e a jornalística, mostrando a dura realidade de um trabalhador de engenho, esta análise procurou contribuir para a percepção da ambiguidade que caracteriza o significado de ser brasileiro. Esta dicotomia tem base em dois princípios que se opõem desde os tempos coloniais. A reflexão é de Sérgio Buarque de Holanda no livro Raízes do Brasil, quando examina no segundo capítulo a diferença entre o trabalho e a aventura. Holanda (1988) assinala que esses dois princípios regularam diversamente as atividades dos portugueses que participaram da grande aventura de posse das terras brasileiras no período colonial.

Para o aventureiro, o ideal é colher o fruto sem plantar a árvore. Vive dos espaços ilimitados, dos projetos vastos, dos horizontes distantes. O trabalhador, ao contrário, é aquele 
que enxerga primeiro a dificuldade a vencer, não o triunfo a alcançar. (Holanda, 1988:13).

Segundo o autor, o que o português vinha buscar nas terras do novo mundo era, sem dúvida, a riqueza, mas riqueza que custa ousadia, não riqueza que custa trabalho. O princípio que, desde os tempos mais remotos da colonização, norteou a criação da riqueza no país valia especialmente para a produção agrária "onde todos queriam extrair do solo excessivos benefícios, sem grandes sacrifícios". E o autor destaca: "não foi a rigor uma civilização agrícola o que os portugueses instauraram no Brasil; foi, sem dúvida, uma civilização de raízes rurais" (Holanda, 1988: 21).

No entanto, se o gosto pela aventura levou os portugueses a se embrenharem cada vez mais em regiões distantes, alargando a posse sobre as terras antes fixadas pelo Tratado de Tordesilhas, sem dúvida foi a necessidade de trabalhar e fazer a terra render seus frutos que permitiu a fixação agrária. O personagem Gregório, da reportagem da revista Realidade, é com certeza um retrato dos portugueses que para o Brasil vieram como colonos, para trabalhar na lavoura da cana de açúcar. Ele descende dos portugueses, dos índios e também dos africanos que, juntos, enfrentaram a dura tarefa de trabalhar nos engenhos. A matriz cultural está presente nesses heróis invisíveis, que têm a cultura e a ética do trabalho, a fixação na terra apesar das dificuldades e da miséria reinante. São heróis que também sonham, mas permanecem presos ao seu canavial, que lhes dá magro sustento. Vivem alheios às inovações tecnológicas e usam a mesma foice para cortar a cana que foi usada pelos seus ancestrais.

Como exemplo da outra matriz cultural portuguesa, a da aventura, temos a narrativa de Macunaíma, o herói que sai para o mundo em busca de uma pedra mágica, que busca a realização fácil, que apela para o jeitinho sempre que se vê em dificuldades. Muitas vezes desperta tarde demais dos seus sonhos. Para Da Matta, o jeitinho pode 
ser um atalho para realizar mais rápido um desejo. "Que modo é este?" pergunta Da Matta. E ele mesmo responde: "é, sobretudo, um modo simpático, desesperado ou humano de relacionar o impessoal com o pessoal. É um modo pacífico e até mesmo legítimo de resolver problemas". (Da Matta, 1986: 99).

Vivendo a realidade da luta pela sobrevivência diária, reproduzida pela reportagem de Realidade, sonhando com a possibilidade de aventuras em terras brasileiras como as vividas por Macunaíma, o brasileiro hoje é o protagonista de uma construção identitária que ainda se divide entre o real e o sonho. Mas, cada vez mais, a realidade se impõe e o brasileiro vai descobrindo que não existe mágica, nem Muiraquitã, nem mãe do Mato capaz de transformar as condições de vida do país, da noite para o dia. É um processo que desmistifica as narrativas lendárias e leva o personagem a enfrentar a vida com o trabalho duro que marcou a história do país em quinhentos anos.

\section{REFERÊNCIAS BIBLIOGRÁFICAS}

ANDRADE, J. (1970). O canavial esmaga o homem. São Paulo: Realidade.

ANDRADE, M. (2008). Macunaíma. Rio de Janeiro: Nova Fronteira.

BABO-LANÇA, I. (2012). "Acontecimento e Memória". In FRANÇA, V. V. e OLIVEIRA, L. Acontecimento: reverberações. Belo Horizonte: Autêntica.

BARTHES, R. (1971). Análise Estrutural da Narrativa. Petrópolis, R/J: Editora Vozes. BUARQUE DE HOLANDA, S. (1988). Raízes do Brasil. Rio de Janeiro: José Olympio Editora.

CAMPBell, J. (2007). O herói de mil faces. São Paulo: Editora Pensamento.

DAMATTA, R. (1986). O que faz o brasil Brasil? Rio de Janeiro: Rocco.

FRANÇA, V. V. (2012). "O acontecimento para além do acontecimento: uma ferramenta heurística". In FRANÇA, V. V. E OLIVEIRA, L. (Orgs.). Acontecimento: Reverberações. Belo Horizonte: Autêntica.

GANCHO, C. V. (1991). Como Analisar Narrativas. São Paulo: Editora Ática. 
MONTORO, T. e CALDAS, R. (Orgs.) (2006). De olbo na imagem. Brasília: Fundação Astrojildo Pereira e Editorial Abaré.

MOTA, C. M. (Org.) (2012). Narrativas Midiáticas. Florianópolis: Insular.

MOTA, C. M. e ALMEIDA, P. (2014). "Jornalismo e redes sociais: identidade e cidadania”, in Revista eletrônica Eco-Pós. Rio de Janeiro: Editora da Universidade Federal do Rio de Janeiro.

MOTTA, L. G. (2005). Narratologia: teoria e análise da narrativa jornalística. Brasília: Casa das Musas.

MOTTA, L. G. (2013). Análise Crítica da Narrativa. Brasília: Editora Universidade de Brasília.

MOUillaud, M.; PORTO, S. (Org.) (2012). O jornal: da forma ao sentido. $3^{\mathrm{a}}$. ed. Brasília: Editora Universidade de Brasília.

ORTIZ, R. (1987). Cultura brasileira e identidade nacional. 3. ${ }^{a}$ Ed., São Paulo: Editora Brasiliense.

PROPP, V.; MELETINSKII, E. M. (1970). Morphologie du conte: suivi de Les transformations des contes merveilleux et de L'estude structurale et typologique du conte. Paris: Seuil.

QUÉRÉ, L. (2005). "Entre facto e sentido: a dualidade do acontecimento", in Trajectos: revista de Comunicação, Cultura e Educação. Lisboa, n.6, pp.59-76.

QUÉRÉ, L. (2012). "A dupla vida do acontecimento: por um realismo pragmatista”, in FRANÇA, V. V. E OLIVEIRA, L. (Orgs.). Acontecimento: Reverberações. Belo Horizonte: Autêntica.

RICOEUR, P. (1994). Tempo e Narrativa. Campinas: Editora Papirus.

RICOEUR, P. (2014). A Memória, a história, o esquecimento. Campinas: Editora Unicamp.

RODRIGUES, A. D. (1993). "O Acontecimento", in TRAQUINA, N. (Org.) Jornalismo: questões, teorias e "estórias". Lisboa: Vega.

SODRÉ, M. (2009). A narração do fato. Petrópolis: Editora Vozes. 
(Página deixada propositadamente em branco.) 
A NARRATIVA NOS MEDIA DIGITAIS 
(Página deixada propositadamente em branco.) 


\section{ERA PÓS-PC: \\ A NOVA TESSITURA DA NARRATIVA JORNALÍSTICA NA WEB}

João Canavilhas

Universidade da Beira Interior / Labcom.IFP

Alciane Baccin

Universidade Federal do Rio Grande do Sul

Ivan Satuf

Universidade da Beira Interior/Labcom.IFP

\section{Introdução}

A popularização dos dispositivos móveis de comunicação ligados a redes de alta velocidade alterou a forma como se faz e consome informação jornalística. Neste trabalho analisam-se as novas narrativas desenvolvidas para dispositivos móveis, tendo como referências as noções de "tessitura da narrativa" e de "ecossistema mediático".

Se em Portugal a palavra tessitura está associada à música, sendo utilizada para descrever a organização entre os elementos de uma composição, no Brasil refere-se ao ato de produzir tapeçaria numa tela ou o resultado final deste trabalho. 
Embora aplicada em campos diferentes, há um denominador comum aos dois significados - as ligações - por isso pode dizer-se que a tessitura, quando aplicada à narrativa, se refere ao conjunto de ações que ligam elementos num determinado suporte. Numa perspetiva histórica, o jornalismo online sempre esteve vinculado ao computador pessoal (PC). Os conteúdos eram desenvolvidos tendo em consideração os seus limites e potencialidades, mas também as condições de receção que eram razoavelmente conhecidas em termos de espaço e tempo de consumo.

A emergência dos dispositivos móveis fez o termo "online" deixar de ser sinónimo de PC. A narrativa deixou de estar confinada a um suporte específico e espalhou-se por outras plataformas, como smartphones, tablets ou relógios inteligentes, que reconfiguraram as relações espácio-temporais. Esta mudança obriga a pensar em mudanças estruturais na narrativa e na forma como ela se reconfigura dentro de um novo ecossistema mediático. As alterações impõem a necessidade de procurar novas categorias para pensar a narrativa jornalística online num ambiente marcado pela diversidade de suportes.

Com essa finalidade, este trabalho organiza-se em quatro partes. As duas primeiras apresentam a perspetiva ecossistémica dos meios de comunicação e a forma como a evolução do jornalismo na web acompanhou o surgimento de novos elementos tecnológicos. A terceira parte analisa o conceito de tessitura da narrativa para propor a sua integração na nova realidade comunicacional. A última parte apresenta cinco categorias associadas à narrativa online contemporânea: base-de-dados, continuum multimédia, contextualização, imersão e paralaxe/verticalização.

\section{Transformações no ecossistema mediático}

A popularização dos computadores pessoais, juntamente com a emergência da World Wide Web nos anos 1990, expandiram a comunicação 
online para além dos círculos restritos de especialistas. Gradualmente, a internet passou a fazer parte do quotidiano das pessoas comuns, quer no ambiente doméstico quer no local de trabalho.

No período inicial de expansão da web, todos os conceitos estavam fortemente vinculados aos PC: expressões como "interação mediada por computador" ou "comunicação mediada por computador" passaram a ser utilizadas com frequência nos debates sobre as novas práticas sociais (Turkle, 1995; Primo, 2007). A transição entre a vida "on" e "offline" só era possível com o uso do computador pessoal, uma máquina geralmente composta pela integração de CPU $^{120}$, monitor, teclado e rato.

A expansão das redes $w i$-fi de alta velocidade e o surgimento de dispositivos móveis de comunicação alterou decisivamente o panorama da internet no decorrer da primeira década do século XXI. Estes novos aparelhos, com dimensões reduzidas e capacidades computacionais, quebraram a tradicional ligação do consumo online a espaços pré-estabelecidos onde geralmente se colocava o computador pessoal. Hoje não é preciso ter um PC para aceder à Internet e distribuir informação online. Smartphones e tablets criaram um ambiente imersivo que esbate as fronteiras entre o online e o offline. As barreiras tendem a desaparecer numa era em que os meios são ubíquos e estão permanentemente ligados à rede (Deuze, 2012), e a ubiquidade tornou-se mesmo num conceito-chave para entender a comunicação numa era em que as tecnologias estão omnipresentes e facilitam a mobilidade do consumidor.

Neste contexto, vale a pena referir a "falácia da caixa-preta": segundo Jenkins (2006), todo o fluxo mediático passa por um só dispositivo capaz de substituir todos os restantes meios de comunicação. Esta falácia, inicialmente associada aos computadores, está hoje cada vez mais associada às tecnologias móveis, principalmente

\footnotetext{
${ }^{120}$ CPU é a sigla em inglês para Central Processing Unit ou Unidade Central de Processamento, em português.
} 
aos smartphones. O erro central está no facto de analisar a inovação na perspetiva da substituição, considerando que os novos meios integram as funções dos seus antecessores e, por consequência, aniquilam os velhos media.

O desenvolvimento tecnológico não pode ser compreendido como um processo linear caracterizado pela mera substituição de um meio de comunicação por outro, mas como uma intensificação das interações entre meios. Nesta perspetiva, as diferentes formas mediáticas estabelecem relações entre si e a sua adaptação aos novos cenários comunicacionais é uma condição fundamental para a sua sobrevivência. Fidler (1997: 29) recorre às noções de "coexistência e "coevolução" para descrever um complexo sistema adaptativo no qual "à medida que novas formas emergem e se desenvolvem, influenciam, com o passar do tempo e em variados graus, o desenvolvimento de todas as outras formas existentes" ${ }^{121}$.

Bolter e Grusin (2000) desenvolveram o conceito de "remediação" como resposta à abordagem linear do desenvolvimento das tecnologias de comunicação. "O que há de novo sobre os novos meios de comunicação vem das maneiras específicas como estes remodelam os media mais antigos e das maneiras como os media mais antigos se remodelam para responder aos desafios dos novos media"122 (Bolter \& Grusin, 2000: 15). Scolari (2013) chama a este processo "simulação", sublinhando que, enquanto o novo meio tenta criar o seu próprio nicho, o meio antigo luta para sobreviver, usando ambos a mesma estratégia: imitar (ou simular) as características dos meios que o rodeiam.

\footnotetext{
${ }^{121}$ Original: "As each new form emerges and develops, it influences, over time and to varying degrees, the development of every other existing form."

${ }^{122}$ Original: What is new about new media comes from the particular ways in which they refashion older media and the ways in which older media refashion themselves to answer the challenges of new media."
} 
Coexistência, coevolução, remediação e simulação são conceitos que têm uma estreita relação com a Medium Theory, corrente que influenciou os estudos comunicacionais a partir dos anos 1950 e cujos principais expoentes foram Harold Innis e Marshall McLuhan (Meyrowitz, 1994). Innis (2011) propõe uma abordagem "concorrencial" entre os suportes de comunicação que permite observar a intrincada relação entre o substrato físico de cada meio e a perspetiva comunicacional responsável por influenciar a forma como as pessoas comunicam. Defender que os meios concorrem uns com os outros significa assumir a perspetiva relacional em detrimento de modelos de análise que tendem a tratar cada tecnologia de comunicação como uma forma única e alheia ao que o rodeia.

McLuhan (1990: 71) segue o mesmo raciocínio, mas em vez de concorrência, preferiu usar o termo "hibridização", processo em que "todos os meios andam aos pares, um atuando como 'conteúdo' do outro". O cinema, por exemplo, não é um meio autónomo, pois meios anteriores, como a literatura, o teatro e a música, agem como seus conteúdos. Se os meios de comunicação, de facto, funcionam como um sistema de acoplagem, os estudos em comunicação devem optar pela lógica da interdependência dos meios em vez de promoverem análises isoladas.

Neil Postman seguiu a linha de raciocínio de Innis e McLuhan para fundar as bases sobre as quais se ergueu o campo conhecido como Media Ecology. As formulações iniciais estimularam a compreensão das tecnologias comunicacionais a partir da metáfora ecológica importada da biologia. Assim, os meios em constante interação formam um "ecossistema mediático" complexo e em constante transformação. Cada novo meio é descrito como uma "espécie" emergente que se relaciona com outras formas - novas e antigas - numa tentativa conjunta de reestabelecer o equilíbrio de todo o sistema.

A comunicação contemporânea é marcada, portanto, pela divergência do hardware e a simultânea convergência dos conteúdos (Jenkins, 
2006), ou seja, há mais aparelhos que servem como pontos de passagem nas trocas comunicacionais e a vida online é marcada pela manipulação constante das diferentes tecnologias de conexão. Canavilhas (2011) sugere que os conteúdos devem ter em consideração um elevado grau de contextualização resultante da personalização do consumo e da mobilidade, capacidade proporcionada pelas redes digitais.

As duas mudanças principais nos fatores contextuais são uma consequência da entrada da internet e dos dispositivos móveis no ecossistema mediático: falamos da individualização do consumo e da mobilidade. Através de computadores pessoais, plataformas de jogos, PDA ou telefones móveis, os consumidores mudaram os seus padrões de consumo mediático, que passaram de contextos grupais a contextos individuais, e de espaços pré-determinados a qualquer lugar onde há uma rede móvel. ${ }^{123}$ (Canavilhas, 2011: 19).

Neste novo ambiente fortemente marcado pela ubiquidade, mobilidade e consumo individual, consequência da popularização dos dispositivos móveis ligados a redes de alta velocidade, o surgimento de novas narrativas online acaba por ser uma consequência natural.

\section{Evolução da narrativa jornalística na web}

Há mais de 20 anos, momento em que o jornalismo começou a crescer na internet, surgiu um desafio: como consolidar um novo meio que

\footnotetext{
123 Original: "Los dos cambios principales en los factores contextuales son una consecuencia de la entrada de Internet y de los móviles en el ecosistema mediático: hablamos de la individualización del consumo y de la movilidad. A través de ordenadores personales, plataformas de juegos, PDAs o teléfonos móviles, los consumidores cambiaron sus patrones de consumo mediático, que han pasado de contextos grupales a contextos individuales, y de espacios predeterminados a cualquier lugar donde haya una red móvil."
} 
parecia juntar os meios anteriores? As primeiras iniciativas jornalísticas na internet não trouxeram nenhuma novidade, mas a dinâmica própria da web não tardou: desde maio de 1993, momento em que apareceu o primeiro jornal com versão online (San Jose Mercury News) ${ }^{124}$ até ao atentado contra as Torres Gémeas, em 11 de setembro de 2001, passaram menos de 10 anos, mas foi o suficiente para o jornalismo se estabelecer definitivamente no ambiente web (Katz, 2001; Zelizer, Allan, 2002; Ferrari, 2003; Malini, 2009; Migowski, 2013).

Ao longo das últimas décadas, o jornalismo na web tem estado em constante transformação nos campos da produção, distribuição e consumo. Dentro da produção, este trabalho centra-se especificamente nas adaptações verificadas no campo da narrativa jornalística. Desde os primeiros anos, são muitas as etapas percorridas pelo jornalismo na Web na tentativa de desenvolver produtos adequados ao meio, procurando desta forma comunicar de maneira mais eficiente com o público. Essas etapas foram estudadas por vários investigadores como Cabrera Gonzalez (2000), Pavlik ${ }^{125}$ (2005), Pryor ${ }^{126}$ (2002), Palacios (2002), Mielniczuk (2003), Barbosa $(2007,2013)$ que procuraram traçar um percurso do jornalismo na web. Embora com algumas diferenças de pormenor, as propostas têm muitos pontos em comum: neste trabalho parte-se da proposta de três gerações do jornalismo na web

\footnotetext{
${ }^{124} \mathrm{O}$ autor admite que outros jornais possam ter surgido antes na internet, mas o San Jose Mercury News foi o primeiro a colocar todo o conteúdo da edição online.

${ }^{125}$ John Pavlik (2005) propõe uma sistematização em três fases do jornalismo na web, tendo como foco a produção de conteúdos. Na primeira, predominam os sites jornalísticos que publicam material editorial produzido para outros meios, os quais o autor denomina de "modelo-mãe". Na segunda fase, dá ênfase aos conteúdos originais produzidos para o online, com o uso de links. Já a terceira fase caracteriza-se pela produção de conteúdos noticiosos originais e que utilizam recursos multimédia, pensados e desenvolvidos especificamente para o novo meio - a web, proporcionando o jornalismo contextualizado no qual se experimentam novas formas de storytelling. ${ }^{126}$ Pryor (2002) destaca a existência de três vagas: a primeira vaga (a partir de 1982) caracteriza-se pela utilização do videotexto para a disseminação de informações; a segunda (1993) com o surgimento da web e dos primeiros fornecedores de acesso à Internet (ISP); a terceira (2001) distingue-se pelo desenvolvimento, especialização e sofisticação das empresas, da tecnologia disponível e dos profissionais.
} 
elaborada por Mielniczuk (2003), acrescentando-se as duas propostas por Barbosa $(2007,2013)$.

Primeira Geração (fase da transposição): o conteúdo jornalístico dos webjornais é uma cópia do conteúdo do jornal em papel. A publicação segue a lógica do impresso, com atualização a cada 24 horas. Para Mielniczuk (2003: 32), foi "muito interessante observar as primeiras experiências realizadas: o que era chamado então de 'jornal online', na web, não passava da transposição de uma ou duas das principais matérias de algumas editorias". Como nesta fase não há nenhuma preocupação em explorar as potencialidades do novo meio, o modelo narrativo é igual ao do jornalismo impresso: a única preocupação é ter uma presença no ambiente web.

Segunda Geração (fase da metáfora): os produtos ainda lembram o jornalismo impresso, mas começam a surgir experiências hipertextuais e atualizações mais frequentes, afastando-se assim do modelo de 24 horas do papel. Mielniczuk (2003) também se refere ao uso do correio eletrónico como possibilidade de interação entre jornalistas e leitores e de chats ou fóruns de debates para interação entre os próprios leitores. Segundo a autora, "ao mesmo tempo em que se ancoram no modelo do jornal impresso, as publicações para a web começam a explorar as potencialidades do novo ambiente, tais como links com chamadas para notícias de factos que acontecem no período entre as edições" (Mielniczuk, 2003: 34).

Terceira Geração (fase do webjornalismo): as potencialidades do jornalismo na web começam a ser exploradas de maneira mais efetiva, em parte graças à melhoria das condições tecnológicas para produção e disseminação dos conteúdos jornalísticos. Inicia-se um período em que as instituições jornalísticas vislumbram a possibilidade de oferecerem um produto diferente do que é oferecido pelo impresso. De acordo com Mielniczuk (2003: 36), "nos produtos jornalísticos dessa etapa, é possível observar tentativas de, efetivamente, explorar e aplicar as potencialidades oferecidas pela web para fins 
jornalísticos". Nesta geração surgem novas narrativas jornalísticas graças ao aproveitamento de características do jornalismo na web, como a multimedialidade, a interatividade, a hipertextualidade, a atualização contínua, a memória e a personalização (Bardoel \& Deuze, 2001; Palacios, 2002; Canavilhas, 2014).

Quarta Geração (fase Jornalismo Digital em Bases-de-Dados): o desenvolvimento do jornalismo na web assenta na exploração das bases-de-dados, que passam a influenciar o processo jornalístico na produção, edição, formato de produtos, construção de narrativas hipermédia, experimentação com novos géneros jornalísticos e visualização das informações. Segundo Barbosa, o recurso às bases-de-dados condicionou sempre a inovação "seja atendendo aos propósitos de armazenamento das informações para recuperação e compartilhamento (...) seja para atender às necessidades colocadas para a publicação das edições digitais dos jornais." (Barbosa, 2007: 124)

Estas possibilidades de utilização das bases-de-dados também foram salientadas por Manovich (2006): segundo o autor, são elas que sustentam a construção de narrativas diversificadas no ambiente digital. É ainda nesta geração que a utilização das bases-de-dados apresenta convergência nos modelos narrativos e que as inovações tecnológicas, tanto na produção como na distribuição dos conteúdos jornalísticos, proporcionam o aparecimento de "formatos e/ou géneros emergentes próprios do meio digital" (Larrondo, Mielniczuk \& Barbosa, 2008).

Quinta Geração (fase da medialidade ${ }^{127}$ e das bases-de-dados): as bases-de-dados tornam-se ainda mais presentes no processo de estruturação do jornalismo na web e na convergência dos meios. O Jornalismo Guiado por Dados ou Data Journalism (Barbosa \& Torres, 2013) e os meios móveis surgem como agentes impulsionadores da inovação, "no qual a emergência dos chamados aplicativos

\footnotetext{
${ }^{127}$ Centralidade dos meios na comunicação e nas experiências humanas.
} 
jornalísticos autóctones para tablets são produtos paradigmáticos" (Barbosa, 2013). As características do paradigma do jornalismo de bases-de-dados são a medialidade (pela via da convergência), horizontalidade (no processamento dos fluxos de informações entre as plataformas), continuum multimédia (integração de processos e produtos), meios móveis, aplicações (apps) e produtos autóctones. Pelo menos 5 das mais de 20 funcionalidades das bases-de-dados referem-se às narrativas jornalísticas:

1) integrar os processos de apuração, composição, documentação e edição dos conteúdos; 2) orientar e apoiar o processo de apuração, coleta, e contextualização dos conteúdos; 3) regular o sistema de categorização e qualificação das distintas fontes jornalísticas, indicando a relevância delas; 4) habilitar o uso de metadados para análise de informações e extração de conhecimento, por meio de técnicas estatísticas ou métodos de visualização e exploração como o data mining7. Também assegurando a aplicação da técnica do tagging8; e 5) garantir a flexibilidade combinatória e o relacionamento entre os conteúdos (Barbosa \& Torres, 2013: 154).

A massificação dos dispositivos móveis gerou um novo processo de compreensão jornalística, isto é, os tablets e smartphones obrigaram a uma reconfiguração dos processos jornalísticos nas redes digitais. Para Barbosa (2013: 33), "o cenário atual é de atuação conjunta, integrada, entre os meios, conformando processos e produtos" e os bancos de dados, a medialidade e o continuum multimédia passam a ser determinantes e reconfiguradores das formas de narrar no jornalismo online.

As sistematizações propostas por Mielniczuk (2003) - da primeira à terceira geração - e por Barbosa $(2007,2013)$ - na quarta e na quinta gerações - podem coexistir num mesmo site jornalístico, pois não se referem a processos datados e estanques. 


\section{Tecendo a estrutura da narrativa jornalística na web}

A analogia entre o "ato de tecer um tecido" e a "tessitura da narrativa jornalística" foi feita anteriormente pelos investigadores Cremilda Medina e Paulo Roberto Leandro num livro de 1973 intitulado "A arte de tecer o presente: jornalismo interpretativo". Ao discutirem uma teoria da interpretação, os autores salientam que não basta informar, é preciso contextualizar. A simplificação do ato de informar pode transformar o jornalismo num mero ato burocrático pelo que só a contextualização permite uma narrativa criativa e inovadora. Mas como ocorre essa tessitura da narrativa jornalística neste novo ecossistema marcado pela mobilidade e pela ubiquidade?

Considerando-se que a tessitura da narrativa se refere ao conjunto de ações que ligam vários elementos, construindo um tecido narrativo entre os suportes, pretende-se demonstrar que o jornalismo na web tem criado formas inovadoras para aproveitar as possibilidades que os novos meios proporcionam aos jornalistas.

Tal como foi anteriormente referido, o jornalismo na web começou por estar ligado ao computador. Por isso, a tessitura da narrativa nas primeiras gerações do jornalismo na web foi pensada dentro dos limites impostos pelos computadores pessoais, fossem eles portáteis ou de secretária. Considerando a emergência de um novo ecossistema mediático, e as características detalhadas por Barbosa (2013) na quinta geração do jornalismo na web, coloca-se o desafio da superação, isto é, de pensar a tessitura sobre uma trama que se adapte aos dispositivos móveis.

Antes disso é preciso refletir sobre o momento em que ocorreram as mudanças na estrutura da narrativa jornalística na web. É justamente na terceira geração do jornalismo na web (Mielniczuk, 2003) que o hipertexto passa a ser um elemento preponderante na construção da notícia, tornando-se no elemento central da narrativa. Essa geração coincide com a terceira fase do jornalismo na web identificada igualmente por 
Pavlik (2005) e Cabrera Gonzalez (2000), destacando-se a importância das experimentações com novas formas de narrar factos (storytelling). Este momento é marcante porque até esse momento usava-se a narrativa da imprensa tradicional resumida a "textos que informam, mas não empolgam, muito menos motivam. Não mobilizam a adesão e participação dos leitores ou conseguem resultados pífios" (Lima, 2014: 123). Esta transposição de conteúdos do impresso, o chamado shovelware, é apontado ainda hoje como uma das razões para a crise do jornalismo, ao ter causado um empobrecimento da narrativa e frustrado as expectativas dos leitores em relação ao potencial do meio (Neveu, 2014).

Com o hipertexto abriram-se novas possibilidades de inovação narrativa para o jornalismo feito na web. A hipertextualidade (Landow, 1997, 2009; Mielniczuk, 2003; Canavilhas, 2014 ; Mielniczuk et al., 2015) é uma das características fundamentais na exploração do potencial oferecido pela web. Ao proporcionar a ligação entre blocos de informações por meio de links, o hipertexto permite ao utilizador um consumo noticioso personalizado com um simples clique. Este poder conferido ao utilizador desencadeia ações que permitem uma maior e mais profunda interação com a plataforma. A hipertextualidade, em conjunto com a multimedialidade e a interatividade, facilitam a produção de narrativas convergentes e imersivas que, aliadas à memória e à personalização, permitem ainda incrementar a contextualização dos factos, valorizando elementos que fortalecem as narrativas de aprofundamento

Investigadores de diversas áreas, como as artes (Manovich, 2006), a literatura (Murray, 2003; Ryan, 2004), o entretenimento (Jenkins, 2006) ou os jogos (Brown, Cairns, 2004), defendem a necessidade de se criarem estórias utilizando meios diferenciados e tecnologias contemporâneas. No jornalismo estas iniciativas têm sido desenvolvidas a título experimental, algumas das quais com grande êxito. É o caso da reportagem "Snow Fall" do The New York Times, publicada em 2012, que foi considerada um modelo desta estrutura narrativa 
pela estória relatada, mas sobretudo porque as modalidades comunicativas $^{128}$ (Canavilhas \& Baccin, 2015) foram bem integradas na narrativa e contribuíram para a contextualização do acontecimento. O sucesso foi tão grande que os jornalistas norte-americanos, quando na posse de uma boa estória, passaram a perguntar: can we "snowfall" this? (Dowling \& Vogan, 2014; Sullivan, 2013). Canavilhas (2014a) faz uma análise de 1155 comentários dos leitores de Snow Fall e constata que 798 fazem referência às características da reportagem, destes $98 \%$ avaliaram positivamente o trabalho e destacaram a qualidade e originalidade da narrativa multimediática. "Mais do que uma metamorfose ou uma remediação, este trabalho é um bom exemplo de diferenciação do webjornalismo em relação aos jornalismos dos meios anteriores, sendo bem visíveis alguns elementos de rutura" (Canavilhas, 2014a : 126). Os elementos que causaram uma rutura com os modelos narrativos anteriores foram a verticalização da narrativa, a autonomização do vídeo em formato sincrónico e a forma como os conteúdos multimédia são integrados no texto. No entanto, o autor sublinha que esta linguagem se aplica sobretudo a géneros longos, como a reportagem. O jornalismo longform (Sharp, 2013; Longhi, 2014, 2015; Tenore, 2014) é uma evolução da narrativa jornalística web e com ela "surge um ponto de virada em relação aos produtos na forma de especiais multimídia que dominaram até então, nos quais o texto, geralmente longo, era tratado e disponibilizado na forma de fragmentos" (Longhi, 2014: 912). A autora acrescenta que o jornalismo longform também se caracteriza por narrativas textuais mais consistentes e formas inovadoras relativas ao design, à navegação e à imersão do utilizador.

\footnotetext{
128 "Por modalidades comunicativas entendem-se todos os recursos utilizados para facilitar e melhorar a compreensão dos acontecimentos relatados nas reportagens, podendo ser texto escrito, áudio, vídeo, fotografias, animações ou infográficos" (Canavilhas \& Baccin, 2015). Esta expressão, adaptada da obra de John Pavlik (2005), salienta que o relato interativo inclui uma ampla gama de modalidades de comunicação, como o texto, as imagens, os vídeos e os gráficos.
} 


\title{
As potencialidades do tecido hipernarrativo
}

No atual ecossistema mediático, a narrativa jornalística deve assumir formas inovadoras e explorar todas as suas potencialidades. Numa sociedade complexa, os acontecimentos não se desenrolam de maneira isolada e, por isso, requerem narrativas ampliadas, rigorosas e contrastadas que só encontram resposta num "jornalismo sistema”:

\begin{abstract}
apostar em um jornalismo sistema é desenvolver um jornalismo que não desuna os acontecimentos; que os contemple e os articule em um contexto determinado e que estabeleça uma gama de interações com os recetores que possa contribuir com a construção do sentido e a compreensão da realidade (Fontcuberta \& Borrat, 2006: 41).
\end{abstract}

De acordo com este modelo de jornalismo, a hipernarrativa ${ }^{129}$ no webjornalismo de quinta geração procura ligar os conteúdos, articulá-los e explicá-los, integrando os factos num determinado contexto que facilita a sua compreensão. A hipernarrativa tem suficiente flexibilidade para estabelecer variações no desenho da informação sem que se percam os significados. Por isso, neste trabalho é analisada a construção da hipernarrativa e são destacadas algumas potencialidades que ela apresenta, nomeadamente bases-de-dados, continuum multimédia, contextualização, imersão e verticalização.

Bases-de-dados: Segundo Barbosa (2004), são entendidas como uma metáfora do jornalismo da web, pois elas representam a forma cultural simbólica que diferencia o online do impresso. Neste

\footnotetext{
129 Para Manovich (2006), as bases-de-dados são responsáveis por uma nova definição de narrativa, a hipernarrativa, que resulta da soma das trajetórias efetuadas através das bases-de-dados. Adota-se este termo porque se identifica a base-de-dados como uma potencialidade da narrativa no ambiente online.
} 
trabalho usa-se igualmente esta potencialidade como metáfora de um jornalismo caracterizado pela organização complexa que inclui os processos de armazenamento, disponibilização, apresentação e consulta dinâmica da informação. A utilização de bases-de-dados e de modelos inovadores de visualização da informação possibilita o surgimento de novas formas de narrar os factos e de formatos noticiosos mais dinâmicos. Para Machado, a "narrativa, em vez de uma sucessão de ações, configura-se cada vez mais como uma viagem através do espaço constituído pelos conjuntos estruturados de itens organizados na forma base de dados e torna-se um conjunto contínuo de ações narrativas e explorações" (2006: 50). De acordo com o autor, o fluxo dos novos modelos de narrativa jornalística incorpora e depende diretamente da intervenção do utilizador/leitor.

Bradshaw (2012) procurar diferenciar o jornalismo de dados (data journalism) do jornalismo tradicional. Segundo este autor, a resposta pode estar nas novas possibilidades resultantes da união entre o tradicional "faro jornalístico" e a capacidade de contar uma estória envolvente recorrendo aos muitos dados existentes sobre cada tema.

Um bom exemplo do recurso às bases-de-dados é a reportagem "Bicho de Sete Cabeças ${ }^{130 "}$ (Fig. 1), da Agência Pública, publicada em 16 de abril de 2014. A reportagem refere-se às transferências de recursos federais para a educação nas cidades que receberam jogos do Campeonato Mundial de Futebol no Brasil, em 2014. De acordo com os jornalistas, que tiveram acesso aos dados da Matriz de Responsabilidades do "Ministério do Esporte" e ao "Portal da Transparência”, mantidos pela Controladoria-Geral da União (CGU), os números dos dois órgãos Federais são divergentes. Na reportagem, as bases-de-dados fornecem informação para a reportagem e contribuem para a estrutura da narrativa, pois os leitores podem ter acesso direto aos dados. A reportagem descobriu que não existe uma

\footnotetext{
${ }^{130} \mathrm{http} / / /$ apublica.org/2014/04/bicho-de-sete-cabecas/
} 


\section{Bicho de sete cabeças}

Depois de dois meses de tentativas, governo nāo explica divergência nos dados entre MEC e CGU sobre repasses da verba de educaçâo nas cidades-sede da Copa; entenda os limites da transparência

Em janeiro, a Pública fez uma reportagem baseada em dados incompletos sobre repasses federais à educação nas 12 cidades-sede da Copa do Mundo. Foi um erro, já admitido em um editorial na época. Entre outras coisas, nosso infográfico comparava os valores dos financiamentos a estádios aos repasses federais em educação para cada cidade. Os valores tinham como base a Matriz de Responsabilidades do Ministério do Esporte e o Portal da Transparência, mantido pela Controladoria-Geral da União (CGU).

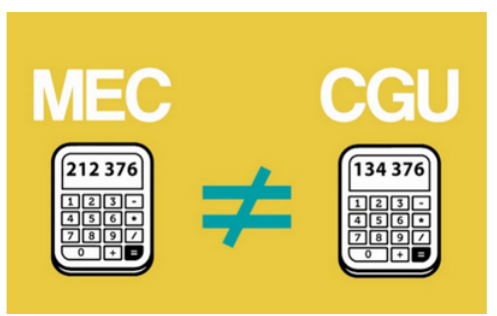

Fig. 1 - Exemplo da potencialidade "bases-de-dados" na narrativa Fonte: http://apublica.org/2014/04/bicho-de-sete-cabecas/

base-de-dados única nem uma norma nacional para contabilizar as transferências de verbas Federais para educação. O trabalho mostra a saga que é encontrar dados fidedignos e a dificuldade para entender este "bicho de sete cabeças".

Contextualização: Os meios online têm um grande potencial de contextualização ao possibilitarem o aprofundamento do tema e o estabelecimento de relações entre temáticas, por não terem limites de tempo/espaço. De acordo com Pavlik (2005), o jornalismo contextualizado reúne cinco aspetos: a) a ampliação das modalidades de comunicação (texto, áudio, vídeo, fotos, gráficos, animação); b) o hipermédia (que permite situar a notícia em contextos históricos, políticos e culturais muito mais ricos); c) a participação cada vez maior dos leitores/utilizadores, que necessitam interagir com 
a máquina ("uma das maneiras de aumentar a participação é o relato imersivo 131") (Pavlik, 2005: 48); d) os conteúdos mais dinâmicos (conteúdos informativos mais fluidos); e) a personalização da informação (cada leitor/utilizador pode filtrar a informação que quiser e ampliar as informações que a reportagem lhe oferece). No webjornalismo, "todas as modalidades da comunicação humana se encontram à nossa disposição para contar estórias da forma mais atrativa, interativa e o mais possível de acordo com seu pedido ${ }^{132}$ " (Pavlik, 2005: 44).

De acordo com os cinco aspetos apontados pelo autor, a contextualização só é possível graças às bases-de-dados que permitem a ampliação das modalidades de comunicação, o hipermédia, a participação de leitores/utilizadores, os conteúdos informativos mais fluidos e a personalização da informação. Outra grande contribuição das bases-de-dados para a contextualização é a possibilidade de memória, que torna possível a integração de outros produtos jornalísticos ou documentos.

Vários aspetos do jornalismo contextualizado podem ser identificados na reportagem "The new cold war" (Fig. 2) sobre a exploração de petróleo no Alaska, publicada no jornal The Guardian, em junho de 2015. O trabalho utiliza todas as modalidades comunicativas (texto, vídeo, áudio, fotografias, infográficos), situa a informação no texto social, ambiental e político, o relato é imersivo e os conteúdos são fluidos e dinâmicos. A reportagem aborda a concessão dada pelo governo norte-americano à Shell para explorar uma das maiores reservas de petróleo do mundo, as consequências ambientais e a possível extinção da população local.

\footnotetext{
${ }^{131}$ Original: "Una de las maneras para aumentar la participación es el relato inmersivo". ${ }^{132}$ Original: "todas las modalidades de la comunicación humana se encuentran a nuestra disposición para contar las historias más atractiva, interactiva, a petición y a medida posible".
} 


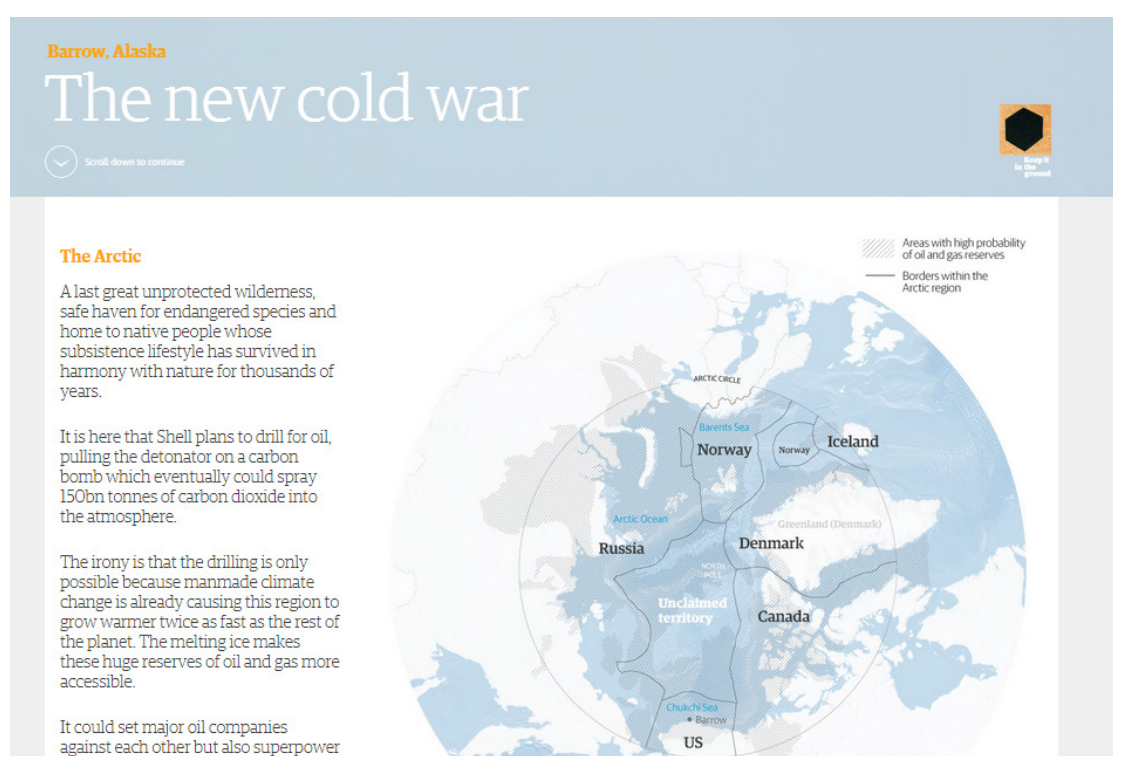

Fig. 2 - Exemplo da potencialidade "contextualização" na narrativa Fonte: http://www.theguardian.com/environment/ng-interactive/ 2015/jun/16/drilling-oil-gas-arctic-alaska

Imersão: A imersão relaciona-se com a contextualização porque é ela que permite a sensação de estar imerso. Com a humanização das narrativas, o leitor é convidado para uma imersão que pode ocorrer em vários sentidos (simbólica, psicológica, racional, emocional). O leitor "é estimulado a captar a realidade e senti-la, porque o grande propósito condutor é dar-lhe elementos para compreender a situação abordada de uma maneira muito mais rica e infinitamente menos rasa do que o texto meramente informativo é capaz de oferecer" (Lima, 2014: 121).

A partir do conceito de imersão nos jogos, Nonny de la Peña (2010) acredita que o jornalismo de imersão é um novo género que utiliza plataformas de jogos e ambientes virtuais para transmitir 


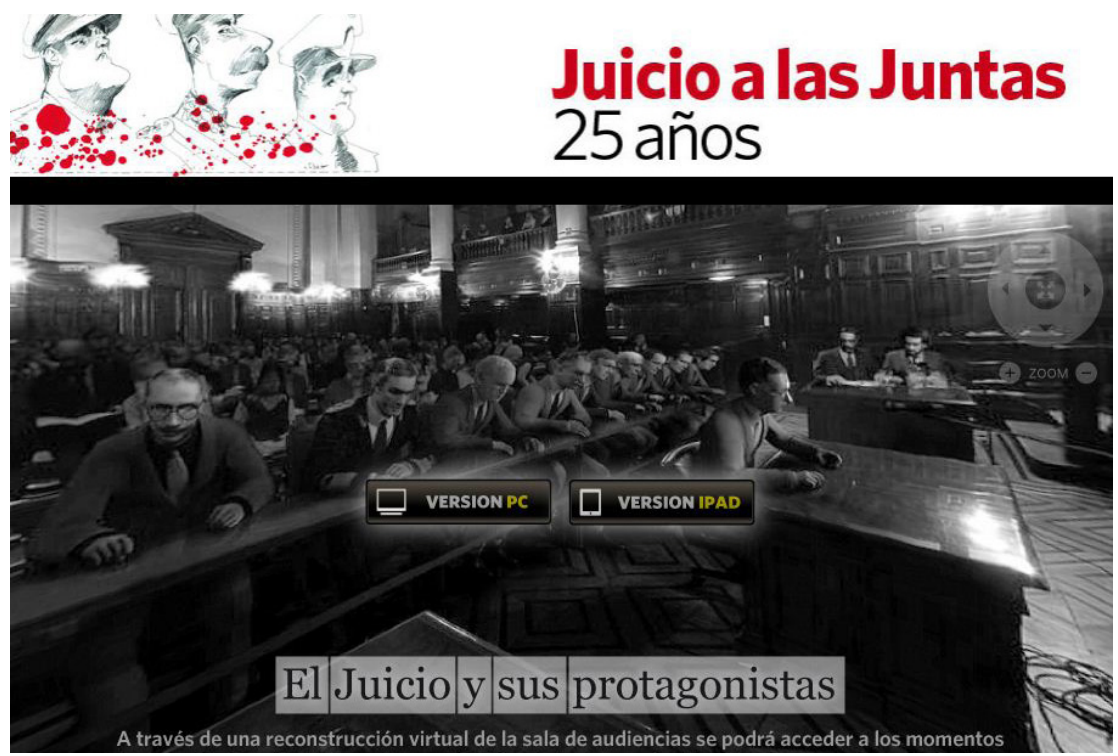

Fig. 3 - Exemplo da potencialidade "imersão" na narrativa Fonte: www.clarin.com/la-sala

notícias, documentários e estórias de não-ficção. "A ideia fundamental do jornalismo de imersão é possibilitar que o usuário realmente entre no cenário que praticamente recria a notícia e a experimente" (Mielniczuk, 2015: 134).

Um exemplo de imersão é a reportagem "La sala del juicio" (Fig. 3), publicada em dezembro de 2010 pelo jornal argentino El Clarín. A reportagem reconstrói virtualmente, 25 anos depois, o histórico julgamento dos militares envolvidos na ditadura argentina. O leitor da reportagem pode movimentar-se dentro da sala do tribunal, escolher qual o ângulo de visão da sala, clicar nas imagens de cada personagem do julgamento para obter mais informações e ainda selecionar sons sobre os depoimentos. 


\section{PILOTE O FOLHACÓPTERO}

\section{Aplicativo permite explorar a usina de Belo Monte}

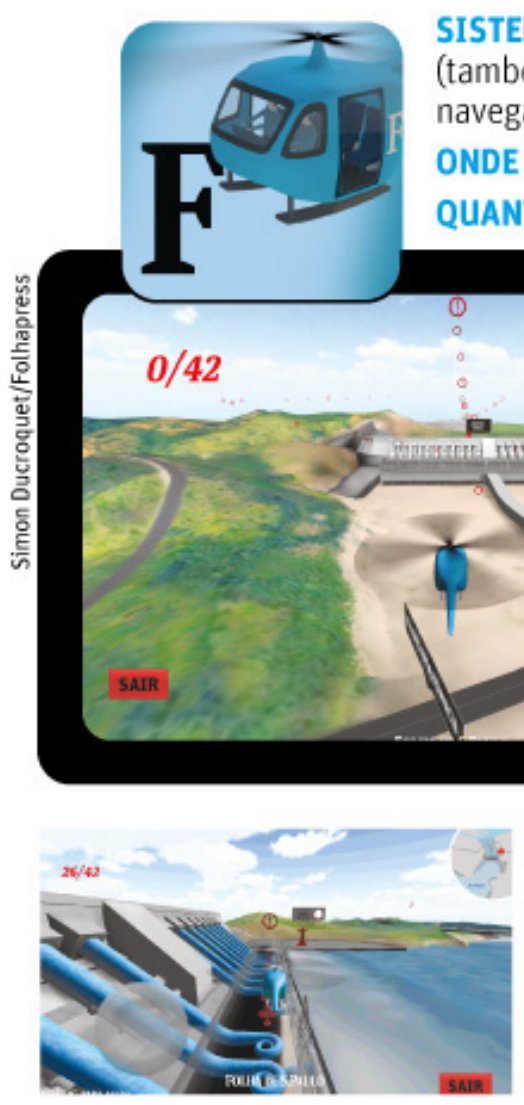

SISTEMA Android e iOS

(também acessível pelo

navegador)

ONDE bit.ly/folhacoptero

QUANTO Gratuito

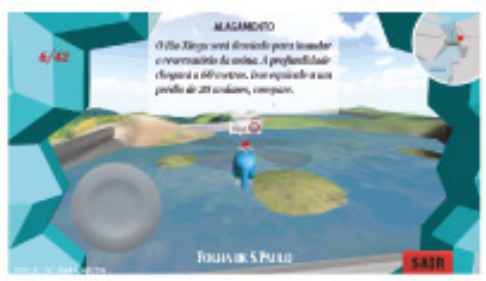

CONTROLE 0 jogador pode pilotar, em modo livre ou automático, 0 Folhacóptero e sobrevoar a área de construção da usina

PONTOS Coleta de anéis vermelhos valem pontos e dicas sobre como usina funciona e quais são seus impactos

Fig. 4 - Exemplo da potencialidade "continuum multimédia" na narrativa Fonte: http://arte.folha.uol.com.br/especiais/2013/12/16/folhacoptero/ 
Continuum multimédia: A quinta geração do jornalismo digital desenvolve-se num cenário de convergência jornalística, no qual "a lógica não é de dependência, competição ou de oposição entre os meios e seus conteúdos em diferentes suportes, característica de etapas anteriores do jornalismo" (Barbosa, 2013: 33). A convergência possibilita o continuum multimédia, pois é por meio dela que a narrativa se expande nos vários meios, possibilitando uma melhor compreensão do contexto narrativo. Os vários meios atuam em conjunto, integrando processos e produtos nos quais os fluxos de produção, edição e distribuição dos conteúdos são horizontais e expansíveis.

O jornal Folha de S. Paulo criou, em 2013, o "Folhacóptero" (Fig. 4) para explicar a construção da usina de Belo Monte, no Estado do Pará (Brasil). Na reportagem existe um ícone que permite fazer o download da aplicação e voar sobre a informação. Depois dessa reportagem, que foi a primeira da série "Tudo Sobre", a Folha já utilizou esta técnica noutras narrativas jornalísticas. A aplicação permite uma imersão mais profunda na narrativa, transportando o leitor/utilizador para o ambiente da reportagem. Neste caso, a imersão é potencializada pelo continuum multimédia.

Paralaxe/Verticalização: Até à publicação de Snow Fall, o design e a estrutura visual das narrativas seguiam a lógica dos meios anteriores, com a justaposição de textos, imagens e sons e seções fragmentadas. Snow Fall inova com a introdução da verticalização da narrativa. De acordo com Barbosa, Normande e Almeida (2014: 11), "podemos verificar uma grande diferenciação das narrativas até então publicadas na web: a dimensão das páginas a partir do design verticalizado, mais comum nos produtos autóctones, com aproximadamente 604 pixels de altura”. Canavilhas $\left(2014^{a}\right)$ alarga a discussão desta potencialidade para lá da simples arquitetura da notícia, chamando "reportagem paralaxe" às narrativas que, para além de utilizarem a tecnologia parallax scrolling, apresentam "navegação 


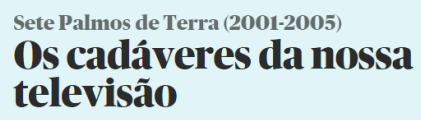

FPEDERICD EATISTA, SIB LLA LND, ANDPEA ESPADNHA \& DINIS CORPELA Os Fisher começaram a despedir-se a 6 de Junho de 2005, há uma década, na estreia da quinta e última temporada da série da HBO. A despedir-se e morrer, como morremos todos "Ninguém fica." Os fass sabiann-no, como sabemos todos, mas nao estavam preparados. E choraram - a morte das personagens e, com isso, dos familiares, dos amigos, a sua própria morte. Estamos prontos para uma visita.

Uma década depois do fim, que morte é esta?

Nunca a morte ficou táo bem a una série. Voltámos à obra de Alan Ball, à cave onde se embelezavam cadáveres para libertar o luto.

Fig. 5 - Exemplo da potencialidade paralaxe/verticalização da narrativa Fonte: http://www.publico.pt/culturaipsilon/noticia/uma-decada-apos-o-fim-dos-sete-palmos-de-terra-que-morte-e-esta-1697938

verticalizada e intuitiva, em conjunto com a plena integração de conteúdos multimédia" tornando "a leitura mais imersiva e envolvente, não requerendo ao utilizador conhecimentos de informática muito profundos" (2014 a : 123).

Essa potencialidade rompe com um modelo até aqui convencional nas narrativas web e imprime um design pensado para os dispositivos móveis. O modelo paralaxe/vertical passou a ser adotado por jornais de todo o mundo, que encontraram em Snow Fall um exemplo a ser seguido. Barbosa, Normande e Almeida acrescentam ainda que "a inovação trazida, inicialmente, por 'Snow Fall' e, posteriormente, pelas narrativas que se seguiram resulta do emprego das bases de dados e de suas funcionalidades no jornalismo em redes digitais" (2014: 17).

A narrativa paralaxe/vertical tornou-se num formato modelo para grandes reportagens. O jornal Público utiliza-o para abordar temas variados: na reportagem sobre os 10 anos de encerramento da série da HBO, "Sete Palmos de Terra", o jornal publicou a reportagem “Os cadáveres da nossa televisão” (Fig. 5), abordando 
as mortes que aconteceram no final da série e relembrando partes emocionantes dos episódios. A narrativa é totalmente vertical e à medida que o leitor/utilizador utiliza o scroll, os vídeos começam automaticamente.

Estes cinco exemplos mostram que as tessituras narrativas no novo ecossistema mediático se afastam definitivamente dos modelos tradicionais anteriores, tornando-se mais envolventes, imersivos e contextualizados. Deve ser referido que as categorias aqui apresentadas não esgotam as novas possibilidades de apresentação de conteúdos jornalísticos. Em todo o mundo são feitas experiências com narrativas desenvolvidas especificamente para dispositivos móveis (Canavilhas \& Satuf, 2013; Bertocchi, Camargo \& Silveira, 2015) que em breve poderão vir a ter uma utilização mais alargada e intensa, tal como aconteceu com as potencialidades estudadas.

\section{Considerações finais}

A popularização dos dispositivos móveis e as mudanças verificadas nos hábitos de consumo obrigaram o jornalismo a procurar narrativas que explorem o potencial deste novo ecossistema mediático. As cinco categorias aqui descritas - bases-de-dados, continuum multimédia, imersão, contextualização e paralaxe/verticalização - são exemplos de respostas a um ecossistema marcado pela ubiquidade e pela mobilidade.

Neste ecossistema, a produção de conteúdos exige criatividade e conhecimentos técnicos que permitam elaborar hipernarrativas capazes de atrair a atenção do leitor/utilizador. O jornalista, tal como um alfaiate, deve ser capaz de costurar com perfeição os diversos elementos que fluem rapidamente de um meio para o outro, elaborando uma boa tessitura da narrativa. 


\section{REFERÊNCIAS BIBLIOGRÁFICAS}

BARBOSA, S. (2004). "Banco de dados como metáfora para o jornalismo digital de terceira geração", in VI Lusocom, III Sopcom, II Ibérico, 2004, Covilhã. Ciências da Comunicação em Congresso na Covilhã. III Sopcom, VI Lusocom, II Ibérico, UBI. Covilhã - Portugal: Universidade da Beira Interior. Available from: <http:// www.bocc.ubi.pt/pag/barbosa-suzana-banco-dados-metafora-para-jornalismo-digital-terceira-geracao.pdf > Accessed: 26 jun 2015

BARBOSA, S. (2007). Jornalismo Digital em Base de Dados (JDBD) - Um paradigma para produtos jornalísticos digitais dinâmicos. (Tese de Doutorado). PósCOM/ UFBA. Available from: http://migre.me/hkrS4 Accessed: 15 de jul. de 2013.

BARBOSA, S. (2008). "Modelo JDBD e o ciberjornalismo de quarta geração". Paper apresentado no GT 7 - Cibercultura y Tendencias de la Prensa en Internet, do III Congreso Internacional de Periodismo en la Red. Foro Web 2.0: Blogs, Wikis, Redes Sociales y e-Participación, Facultad de Periodismo, Universidad Complutense de Madrid (Espanha), 23 e 24 de Abril de 2008.

BARBOSA, S. (2013). "Jornalismo convergente e continuum multimídia na quinta geração do jornalismo nas redes digitais", in CANAVILHAS, J. (Org.). Notícias e mobilidade: o jornalismo na era dos dispositivos móveis. Covilhã, PT: Livros LabCom, pp. 33-54. Available from: http://migre.me/hUrFq. Accessed: 07 set. 2013.

BARBOSA, S.; NORMANDE, N.; ALMEIDA, Y. (2014). "Produção horizontal e narrativas verticais: novos padrões para as narrativas jornalísticas". Trabalho apresentado ao Grupo de Trabalho Estudos de Jornalismo do XXIII Encontro Anual da Compós, na Universidade Federal do Pará, Belém, de 27 a 30 de maio de 2014 .

BARBOSA, S. A.; TORRES, V. (2013) "O paradigma 'Jornalismo Digital em Base de Dados': modos de narrar, formatos e visualização para conteúdos”, in Galaxia, N. ${ }^{\circ}$ 25, São Paulo, pp. 152-164.

BARDOEL, J.; DEUZE, M. (2001). "Network Journalism: Converging Competences of Media Professionals and Professionalism", in Australian Journalism Review 23 (2), pp.91-103. 
BERTOCCHI, D., CAMARGOS, I.O., \& SILVEIRA, S.C. (2015). "Possibilidades narrativas em dispositivos móveis" in CANAVILHAS, J.; SATUF, I. (Orgs.). Jornalismo para dispositivos móveis: produção, distribuição e consumo. Covilhã: Livros LabCom. BOLTER, J. D., \& GRUSIN, R. (2000). Remediation: understanding new media. Cambridge, MA: MIT Press.

BRADSHAW, P.; R. L (2012). The Online Journalism Handbook. Skills to survive in the digital age. Harlow: Pearson.

BROWN, E., \& CAIRNS, P. (2004). "A grounded investigation of game immersion", in CHI'04 - Conference on Human Factors in Computing Systems, Viena/Nova York: ACM Press.

CABrera GONZÁlez, M. A. (2000). "Convivencia de la prensa escrita y la prensa on line en su transición hacia el modelo de comunicación multimédia”, Available from: <http://www.ucm.es/info/periol/Period_I/EMP/Numer_07/74-Comu/7-4-01.htm> Accessed 15 Mai 2013

CANAVILHAS, J. $\left(2014^{\mathrm{a}}\right)$. "A reportagem paralaxe como marca de diferenciação da web”, in REQUEIJO REY, P. y GAONA PISONERO, C. (2014). Contenidos innovadores en la Universidad Actual. Madrid: McGraw-Hill Education, pp. 119-129.

CANAVILHAS, J. $\left(2014^{\mathrm{b}}\right)$. "Hipertextualidade: novas arquiteturas noticiosas", in CANAVILHAS, J. (Org.) Webjornalismo: 7 caraterísticas que marcam a diferença. Covilhã: Livros LabCom, pp. 3-24.

CANAVILHAS, J. (2011). "El nuevo ecosistema mediático", in Index.comunicación, 1, pp. 13-24.

CANAVILHAS, J. \& BACCIN, A. (2015). "Contextualização de reportagens hipermídia: narrativa e imersão" in Brazilian Journalism Research, v.11, n. 1.

CANAVILHAS, J., \& SATUF, I. (2013). "Jornalismo em transição do papel para o tablet... ao final da tarde", in FidAlgO, A. \& CANAVILHAS, J. (Eds.). Comunicação digital: 10 anos de investigação. Coimbra: MinervaCoimbra, pp. 35-60.

DE LA PEÑA, N.; WEIL, P.; LLOBERA, J.; GIANNOPOULOS, E.; POMÉS, A.; SPANLANG, B.; SLATER, M. (2010). "Immersive Journalism: Immersive Virtual Reality for the First-Person Experience of News", in Presence, 19 (4), pp. 291- 301.

DEUZE, M. (2012). Media life. Cambridge: Polity Press. 
DOWLING, D.; VOGAN, T. (2014). "Can we 'Snowfall' this? Digital longform and the race for the tablet market", in Digital Journalism. Epub: 25 mai 2015. DOI:10. 1080/21670811.2014.930250.

FERRARI, P. (2003). Jornalismo digital. São Paulo: Contexto.

FIDLER, R. (1997). Mediamorphosis: understanding new media. Thousand Oaks: Pine Forge Press.

FONTCUBERTA, M., \& BORRAT, H. (2006). Periódicos: sistemas complejos, narradores em interacción. Buenos Aires: La Crujía.

GARRISON, B. (2009). "Online Newspaper”, in SALWEN, M.; GARRISON, B.; DRISCOLL, P. (Orgs.). Online News and the Public. New Jersey: Lawrence Erlbaum Associates, pp. 3-46. INNIS, H. (2011). O viés da comunicação (L.C. Martino, Trad.). Petrópolis, Brasil: Vozes. (Original publicado em 1951)

JACOBSON, S.; MARINO, J.; GUTSCHE JR, R. (2015). "The digital animation of literary journalism”, in Journalism (online). doi:10.1177/1464884914568079

JENKINS, H. (2006). Convergence culture: where old and new media collide. New York: New York University Press.

KATZ, J. (2001). Net: Now Our Most Serious News Medium? Slashot 2001. Available from: <http://features.slashdot.org/story/01/10/05/1643224/net-now-our-most-serious-news-medium>

LANDOW, G. (1997). Teoría del hipertexto. Barcelona: Paidós.

LANDOW, G. (2009). Hipertexto 3.0: teoría crítica y nuevos medios en la era de la globalización. Barcelona: Paidós.

LARRONDO, A.; MIELNICZUK, L.; BARBOSA, S. (2008) "Narrativa jornalística e base de dados: discussão preliminar sobre gêneros textuais no ciberjornalismo de quarta geração", in Anais VI Encontro Nacional de Pesquisadores em Jornalismo (SBPJor). São Bernardo do Campo/SP.

LIMA, E. (2014). "Storytelling em plataforma impressa e digital: contribuição potencial do jornalismo literário", in Revista Organicom, 11: 20, pp. 118-127.

LONGHI, R. (2014). "O turning point da grande reportagem multimídia", in Revista FAMECOS (Online), v. 21, n. 3, pp. 897-917.

LONGHI, R. (2015). "O lugar do longform no jornalismo online. Qualidade versus quantidade e algumas considerações sobre o consumo", in $24^{\circ}$ Encontro 
Nacional da Compós - Associação Nacional dos Programas de Pós-Graduação em Comunicação, Brasília, Universidade de Brasília. Available from: <http:// www.compos.org.br/biblioteca/compos-2015-3c242f70-9168-4dfd-ba4c-0b444ac7347b_2852.pdf> Accessed: 25 jun 2015

MACHADO, E. (2006). OJornalismo Digital em Base de Dados. Florianópolis: Calandra.

MALINI, F. (2009). "Por uma genealogia da Blogosfera: considerações históricas (1997-2001)", in Lugar Comum, n. 23-24.

MANOVICH, L. (2006). El lenguaje de los nuevos medios de comunicación: la imagen en la era digital. Barcelona: Paidós Comunicación.

MCLUHAN, M. (1990). Os meios de comunicação como extensões do homem (understanding media) (D. Pignatari, Trad.). São Paulo, Brasil: Cultrix. (Original publicado em 1964)

MEDINA, C.; LEANDRO, P. (1973). A arte de tecer o presente: (jornalismo interpretativo). São Paulo: Média.

MEYROWITZ, J. (1994). "Medium theory", in CROWLEY, D. \& MICHELL, D. (Eds.). Communication Theory Today. Cambridge: Stanford University Press, pp. $50-77$.

MIELNICZUK, L. (2003). Jornalismo na Web: uma contribuição para o estudo do formato da notícia na escrita hipertextual. (Tese de doutorado). FACOM/ UFBA, Salvador. Available from: <https://repositorio.ufba.br/ri/handle/ri/6057> Accessed 03 abr. 2012.

MIELNICZUK, L.; BACCIN, A.; SOUSA, M.; LEÃO, C. (2015). "A reportagem hipermídia em revistas digitais móveis", in CANAVILHAS, J.; SATUF, I. (Org.). Jornalismo para dispositivos móveis: produção, distribuição e consumo. Covilhã: Livros LabCom.

MIGOWSKI, A. (2013). Memórias coletivas na comunicação mediada por computador : uma análise à luz do acontecimento de 11 de setembro de 2001 em seu décimo aniversário. (Dissertação de mestrado). Porto Alegre, FABICO/UFRGS. Available from: http://www.lume.ufrgs.br/bitstream/handle/10183/76136/000892128.pdf?sequence=1 Accessed: 06 jun 2015

MURRAY, J. (2003). Hamlet no Holodeck: o futuro da narrativa no ciberespaço. (E K Daher \& M F Cuzziol, Trad.). São Paulo: Itaú Cultural: Unesp. 
NEVEU, E. (2014). "Revisiting Narrative Journalism as One of The Futures of Journalism", in Journalism Studies, 15:5, 533-542, doi: 10.1080/1461670X.2014.885683

PALACIOS, M. (2002). Jornalismo online, informação e memória: apontamentos para debate. Available from: http://www.facom.ufba.br/jol/producao.htm. >. Accessed em 12 mai 2013 .

PAVLIK, J. (2005). El periodismo y los nuevos medios de comunicación. Barcelona: Paidós.

PRIMO, A. (2007). Interação mediada por computador. Porto Alegre: Sulina.

PRYOR, L. (2002). The third wave of online journalism. Online Journalism Review. Available from: <http://www.ojr.org/ojr/future/1019174689.php>. Accessed 08 out. 2013 .

RYAN, M-L. (2004). La narración como realidad virtual: la inmersión y la interactividad en la literatura y en los medios electrónicos. Barcelona: Paidós.

SHARP, N. (2013). The future of longform. The Columbia Journalism Review, 9 December. Available from: <http://www.cjr.org/behind_the_news/longform_ conference.php> Accessed 14 mai 2015.

SCOLARI, C. (2013). "Media evolution: emergence, dominance, survival, and extinction in the media ecology", in International Journal of Communication, 7, pp. 1418-1441.

SULliVAN, M (2013). Who gets to 'Snow Fall' or 'Jockey' at the Times and why? New York Times, 20 August 2013. Available from:<http://publiceditor.blogs.nytimes.com/2013/08/20/who-getsto-snow-fall-or-jockey-at-the-times-and-why/> Accessed: 14 mai 2015.

TENORE, M. (2014). "Longform journalism morphs in print as it finds a new home online”. Available from: http://migre.me/oJkre. Accessed 15 jun 2015.

TURKLE, S. (1995). Life on the screen : identity in the age of the Internet. New York: Simon \& Schuster.

ZELIZER, B.; ALLAN, S. (2002). Journalism After September 11. London: Routledge. 


\section{ENTRE TEXTÕES E ESCRITÕES:}

\section{A NARRATIVA PROJETADA}

Daniela Maduro

Centro de Literatura Portuguesa / FLUC

\section{Os escrileitores}

A World Wide Web trouxe consigo inúmeras formas de publicação. Foi no meio digital que o autor veio a assumir a função de blogger ou de gestor de conteúdos. A sua presença é hoje constatada em várias plataformas onde os seus textos podem ser publicados instantaneamente. Para além disso, a junção entre a tecnologia móvel e os media sociais criou a possibilidade de conectividade permanente. A audiência encontra-se hoje à distância de um dígito.

Marie-Laure Ryan, em Avatars of Story (2006), referiu-se a uma abordagem prática à narrativa digital. Esta teria em conta "a importância das histórias na vida das pessoas" (RYAN, 2006: xiii) e veria a World Wide Web como um veículo para a transmissão de narrativas, quer estas fossem publicadas em blogs, em chatrooms ou até num anúncio publicitário. É neste contexto que surge o termo wreader, o leitor que também assume funções de escritor. Esta palavra refere-se hoje à comunidade que lê e publica textos através dos 
seus ecrãs mas, na literatura eletrónica ${ }^{133}$, o termo wreader $^{134}$ viria a representar um leitor livre da hegemonia autoral. Em meados dos anos noventa, Pedro Barbosa, pioneiro em Portugal na produção de literatura combinatória através do computador, referia-se igualmente à existência de um escrileitor "que pratica a leitura pela escrita e a escrita pela leitura numa nova simbiose interactiva" (Barbosa, 1996: 11). Pedro Barbosa criou o programa de geração automática de textos intitulado Sintext, juntamente com Abílio Cavalheiro ${ }^{135}$. De acordo com Barbosa, este programa permitiria criar o seguinte tipo de texto: "o texto surge aqui como uma estrutura geradora de sentidos, ou como texto em processo, e não como meio de comunicação intersubjectiva entre autor e fruidor" (Barbosa, 1996: 11.). O texto surgiria, assim, não como um produto finalizado gerado por um autor, mas como uma matriz de significados.

Para além de reunirem pessoas com interesses em comum, os media sociais estão a ser utilizados para criação artística e literária ${ }^{136}$. A plataforma Facebook, por exemplo, permite a publicação de breves comentários sobre o quotidiano ou partilha instantânea de notícias ou curiosidades, mas também terá motivado a criação de diferentes formas literárias. Um exemplo disso são os microcontos (também intitulados minicontos ou nanocontos) constituídos por uma ou duas linhas, através das quais os leitores partilham pequenas histórias.

\footnotetext{
${ }^{133}$ Esta é uma área em franca expansão e, dada a sua hibridez e dependência da tecnologia - o que permite a criação de novos tipos de textos, mas destina outros à obsolescência -, tornar-se difícil defini-la com precisão. N. Katherine Hayles sugeriu a seguinte definição de literatura eletrónica: "Electronic literature, generally considered to exclude print literature that has been digitized, is by contrast 'digital born', a first-generation digital object created on a computer and (usually) meant to be read on a computer" (Hayles, 2008: 3). ${ }^{134}$ George Landow usou este termo no texto "What's a critic to do? Critical theory in the age of hypertext" (1994) (Schäfer, 2007: 144)

${ }_{135}$ Mais tarde, Barbosa viria a colaborar com José Manuel Torres para criar uma versão web deste programa, o Sintext-Web (2000). Seis poemas criados por Barbosa e organizados por Rui Torres foram publicados no terceiro volume da ELO Collection sob o título Ciberliterature. Estes podem ser lidos em: http://collection.eliterature. org/3/work.html?work=cyberliterature.

${ }^{136}$ Joseph Tabbi refere-se a blogs como "objetos de conhecimento" (Tabbi, 2010: 4).
} 
A página Flash-Fiction ${ }^{137}$, por exemplo, declara que o seu propósito é oferecer aos escritores uma frase inicial de onde poderão partir as suas histórias. A página portuguesa Micro $\operatorname{Contos}^{138}$ tem mais de 24.000 subscritores e descreve-se como um "contador de pequenas histórias". As pequenas narrativas introduzidas pelos escrileitores vêm normalmente acompanhadas de fotografias. Após a inserção de um texto sob a forma de comentário, os leitores podem responder, partilhar ou atribuir um "like", interagindo assim com o autor.

No volume II da Electronic Literature Collection, disponível online, é possível encontrar uma obra que também utiliza a plataforma Facebook como ferramenta criativa. The Fugue Book (2008) usa a informação pessoal contida nesta página, bem como o e-mail do leitor, para criar uma narrativa acerca de questões de privacidade e identidade. A caixa de correio do leitor começa por ser invadida por e-mails de diferentes personagens. Enquanto o leitor lê a obra, é recolhida informação pessoal dos seus amigos na plataforma do Facebook. O conjunto de dados reunido permite que as personagens ajam como se mantivessem uma relação de amizade com este. The Fugue Book é um exercício irónico sobre questões de identidade, que usa plataformas como wikis, fóruns, histórias eróticas, blogs e outros media sociais para formular uma narrativa. De acordo com o autor, o leitor poderá fugir de tudo, mas não poderá fugir de si próprio: "The Fugue fa participar els teus amics en la ficció. Els teus amics no es comportaran igual que ho fan a The Fugue (o potser

\footnotetext{
${ }^{137}$ A página em questão pode ser consultada em: https:/www.facebook.com/pages/ Flash-Fiction-Chronicles/111807932198001?fref=ts. Existe uma outra página onde é explicada a origem do termo: https://www.facebook.com/pages/Flash=-fiction107726225923884/?frefts\&rf=177360282408549\#.

${ }^{138}$ A página pode ser consultada em: https://www.facebook.com/microcontos. Recentemente foi publicado um livro com o conteúdo desta página, o que comprova que o formato impresso e formato digital, frequentemente considerados como oponentes, podem, na verdade, coexistir e persistir.
} 
sí, encara que no t'ho sembli). Si vols, podràs fugir d'ells. Fins i tot podràs fugir de The Fugue, però no podràs fugir de tu mateix"139.

Para além do Facebook, existem outras plataformas que possibilitam a publicação instantânea de um texto. Muitos dos processos de escrita adotados recordam práticas literárias e artísticas criadas antes da emergência do computador. Estes denunciam igualmente que o desejo de intensificar o papel participativo do leitor é uma tendência que antecede a adoção do computador enquanto recurso para criação literária. Bryan Alexander, num livro dedicado à "digital storytelling", referiu-se às Wikis como um instrumento de escrita colaborativa e defendeu que estas podem assumir a forma do jogo surrealista "cadáver esquisito". Este é o processo de composição usado para produzir o romance exquisite_code (2010). Durante cinco dias, um grupo de escritores sentou-se a uma mesa para escrever ao longo de oito horas. Uma audiência assistia à escrita deste romance. Este detalhe torna esta atividade numa performance, bem como anula a fixidez associada à escrita. exquisite_code contraria a noção de escrita e leitura como atividades solitárias. Segundo Mark Marino, "exquisite_code rompe com a noção romântica de um texto criado por um único autor" (Marino, 2013: 285).

Ao longo da escrita do romance exquisite_code (2010), existe um narrador $\left(\right.$ proctor $^{140}$ ) que lê em voz alta o resultado da experiência. Esta é descrita da seguinte forma:

Reading the text, then, becomes a game of trying to detect the signatures of the particular collaborators in the mash,

\footnotetext{
139 "The Fugue faz com que os teus amigos participem na ficção. Os teus amigos podem não se comportar como o fazem no The Fugue (ou talvez possa assim parecer). Se tu quiseres, podes evitá-los. Tu podes até escapar do The Fugue, mas não podes escapar de ti mesmo".

${ }^{140}$ Este é também aquele que determina que método de programação deve ser seguido pelos escritores. Para além de funcionar como um sistema autoral, Marino refere que este é uma metonímia do código usado para construir exquisit_code.
} 
as evidenced by repeating themes, diction, and punctuation, as well as deducing the process, how each passage grew out of the dynamics of the group and the randomly selected prompts. (Marino, 2013: 285).

Sendo assim, a leitura desta obra não se encontra dependente da coerência ou linearidade do texto, mas do rastreamento de detalhes significativos produzidos ao longo do processo de escrita colaborativa. A obra é constituída pela cadeia de código de Markov, uma adaptação algorítmica dos cut ups de William Burroughs e SMS. Este romance pode ainda ser impresso on demand. Na sua versão impressa, vêm incluídas as linhas de código que foram produzidas durante a performance de exquisite_code. Para além de ler o resultado da experiência, o leitor é também convidado a interpretar o código. Toda a performance foi filmada, pelo que o leitor poderá ainda visualizar todo o processo de construção de exquisite_code. Sendo assim, esta obra reúne diversas formas de representação e transforma o ato de contar histórias numa experiência híbrida, tecida por várias mãos.

O podcast é outra das formas de narrar uma história descrita por Alexander. Para este autor, esta forma de publicação reúne vários tipos de media (ou práticas de storytelling):

Listening to a voice or voices tell a story (...) is an ancient human experience, hearkening back to the oral tradition. (...) the podcaster's voice resembles other speaking voices familiar to audiences of different ages and media experience: the radio announcer, the newsreel narrator, the TV anchor, even the ham radio operator. Further, we may also know that telling voice from audiobooks (formerly "books on tape"). We already knew aural performance before downloading the first mp3 into RSS or iTunes. In this way, podcasts are deeply historical, even nostalgic. (Alexander, 2011: 77) 
A categoria Web Video centra-se na imagem em movimento e é resumida por Alexander aos vídeos publicados no YouTube. Nesta plataforma, o autor pode manter um canal próprio e construir um reportório. Pode ainda entrar em contacto com a audiência através do painel de comentários. Comum a todas estas formas de publicação ou práticas de storytelling é o facto de não existir o editor como intermediário entre o leitor e o autor. A aproximação entre ambos faz com que - tal como é sugerido por Alexander no excerto acima citado - o autor se assemelhe ao contador de histórias da tradição oral. Em ambiente digital, a comunicação pode tornar-se bidirecional. Adicionalmente, leitor e autor podem trocar de papéis entre si.

Bryan Alexander afirma que a "digital storytelling" terá surgido com as primeiras experiências com o computador. Segundo o mesmo autor, a história desta prática poderá ter começado de duas formas:

(...) we could begin with a game called Spacewar, an early storytelling engine that dates back to the 1960s. If we think of world-building as storytelling, the first virtual worlds in the early internet age - all text based! — appeared in the late 1970s, with the first MUDs (Multi-User Dimensions or Multi-User Dungeons)" (Alexander, 2011: 17).

De acordo com Alexander, a atividade de contar histórias através do computador está relacionada com a emergência dos jogos de computador e mundos virtuais. No final dos anos oitenta, Roy Ascott sublinhava a chegada de uma nova ordem na arte, a ordem da interatividade e da 'autoria dispersa'. Anunciava igualmente a emergência de um novo cânone: o "cânone do imaterial e participatório" (Ascott, 2002: 339). A telematics seria um conjunto de comunicações estabelecidas entre utilizadores ou instituições dispersas, através do computador. Ascott considerava que esta envolvia a interação entre seres humanos e "entre a mente humana e sistemas artificiais 
de inteligência e perceção" (2002: 334). Na sua descrição de telemática, Ascott mencionava a existência de uma "síntese entre artes" em ambientes interativos. Referia-se igualmente a uma obra de arte total constituída por dados ou uma Gesamtdatenwerk que transformava o observador em participante. Na Gesamtdatenwerk, cabia ao utilizador negociar o significado, o que fazia com que a criatividade residisse, não só no trabalho do artista, mas também na perceção da obra de arte. O "significado" seria assim transformado no produto da interação entre obra e observador. Por este motivo, estaria "num fluxo constante, de mudança e transformação interminável" (2002: 336). Na relação de "simbiose entre humano e máquina" a perceção humana seria para Ascott o produto de negociação. Porque estavam interligados através da rede, os utilizadores tornavam-se em participantes numa "acupunctura global" que constrói "um fluxo de data mundial" (2002: 342). Ascott referia-se a uma arte à escala planetária formada através de um "telematic embrace" (2002: 344). A adoção do computador teria, assim, como objetivo conferir ao leitor um papel mais dinâmico e pertinente na receção ou produção da obra de arte.

Walter Benjamin havia referido, no seu texto sobre a obra de arte na época da sua possibilidade de reprodução técnica, que o leitor pretendia tornar-se em autor (Benjamin, 2003: 29). Benjamin referia-se a artigos de opinião publicados em jornais. Desde as suas primeiras manifestações, a literatura eletrónica tem vindo a ampliar as funções do leitor. A impressão que estas surgem intensificadas perante um computador é produzida pelas características intrínsecas do meio - tais como o célere processamento de informação e a lata capacidade de armazenamento de dados - que cooperam entre si para surpreender o leitor com um vasto número de respostas textuais. Porém, como demonstrarei, um texto digital interativo não se resume à capacidade de oferecer ao leitor um maior poder de intervenção. A interatividade não deve ser representada por um conjunto de tarefas oferecidas ao "escrileitor", nem pela oportunidade de participar na 
construção do texto. Neste artigo, esta será descrita como um elemento expressivo e figurativo manifestado por textos que apresentam uma dinâmica particular.

\section{Ergodicidade e narratividade}

Em 2001, Rita Raley descrevia o funcionamento do hipertexto da seguinte forma: "hypertext works by connection, assemblage, and combination - by connecting content blocks, phrases, phrase regimes, nodes, computers, programs, and lines of code. It is not about signification but mapping: not ordering, tracing, and fixing, but transmission, relay, and movement" (Raley, 2001). O hipertexto seria um texto dividido em lexias interligadas de forma associativa e acedidas aleatoriamente. Já as hiperficções eletrónicas nasciam do aproveitamento dos recursos tecnológicos para concretizar o texto em aberto, fragmentado, rizomático e livre de uma sequência pré-determinada pelo autor. Estas características seriam catalisadas pelo recurso à intervenção do leitor na montagem do texto ${ }^{141}$. Segundo Alice Bell, os primeiros teóricos dedicados ao estudo e produção de ficções hipertextuais reconheciam que a multilinearidade poderia provocar "confusão e desorientação", mas que estas poderiam ser contornadas se o leitor continuasse a ler "até que as suas curiosidades pessoais" fossem satisfeitas (Bell, 2009: 14). Bell refere que, na segunda fase da ficção hipertextual, a questão da multilinearidade e da incoerência ao nível estrutural é revista da seguinte forma: "the structure of the text, and the reader's role within it, represent a means of prohibiting her or him from fully engaging with the

\footnotetext{
${ }^{141}$ Alice Bell refere que esta seria uma falácia mantida na fase inicial da ficção hipertextual: "Overall, while hypertext fiction does offer choice, the reader's degree of control, which was envisaged by many first-wave theorists, is inflated and readers are erroneously attributed with unrealistic powers in their actual capacity to manipulate and operate within the text" (Bell, 2009: 12).
} 
narratives that hypertext novels contain" (2009: 15). Sendo assim, a tónica seria colocada na resistência exercida pelo texto, e não no grau de liberdade, escolha ou participação oferecida ao leitor. Porém, a possibilidade de interatividade - um termo problemático, mas que continua a permear textos teóricos ${ }^{142}$ - e a multilinearidade permaneceram como características fundamentais da literatura eletrónica.

Para além da abordagem prática acima descrita, Marie-Laure Ryan referiu-se igualmente à abordagem expansionista. Esta abordagem vê a narrativa como um conceito mutável, que difere de cultura para cultura e que evolui de acordo com as inovações tecnológicas (Ryan, 2006: xv). Já a abordagem metafórica procura inspiração em conceitos da narratologia para desenhar e promover aplicações que não são originalmente criadas para contar histórias (2006: xiv). Este é o caso de inúmeras narrativas criadas dentro da literatura eletrónica. No entanto, alguns textos produzidos através do computador, dado o seu carácter experimental, interativo ou híbrido, tornam difícil a sua categorização como textos literários ou, mais concretamente, narrativos. Reis referiu-se a "textos narrativos" situados em "vários contextos comunicativos", que recorrem "a diferentes suportes expressivos" e que "apontam para a possibilidade de se estudar a narratividade como processo geral que é comum a todas as narrativas e não apenas exclusivo das literárias" (Reis, 1997: 344). De facto, uma narrativa pode estender-se a várias formas de representação e pode assumir vários perfis. A possibilidade de existência de vários tipos de narrativa exige uma abordagem expansionista.

Markku Eskelinen afirmou que existem textos ergódicos (ou cibertextos) cuja abordagem é permanentemente adiada pelos estudos literários, por ausência de instrumentos de análise adequados.

\footnotetext{
${ }^{142}$ Este termo tem vindo a ser considerado como demasiado abrangente e, por este motivo, improfícuo enquanto conceito teórico (Aarseth, Eskelinen). Embora Aarseth tenha rejeitado este termo, o conceito "interatividade" será aqui utilizado como distinto, mas inseparável, do fenómeno de ergodicidade identificado por este autor.
} 
O adjetivo "ergódico" foi sugerido por Espen Aarseth para descrever todos os textos (impressos ou digitais) que exijam do leitor um "esforço não-trivial" para percorrer o texto (Aarseth, 1997: 1). Isto significa que o leitor tem de levar a cabo um conjunto de escolhas para completar uma sessão de leitura. Todavia, segundo Eskelinen, o conjunto de escolhas formulado pelo leitor institui um conflito entre camadas ergódicas e narrativas. A teoria do cibertexto vê um texto como uma máquina concreta de produção e consumo de sinais e o medium como operador dessa cadeia de sinais. Esta cadeia divide-se entre textões (cadeia de sinais que compõem o texto) e escritões (cadeia de sinais, tal como são apresentados ao leitor/utilizador). Dada a sua volatilidade, os textos ergódicos inviabilizam uma abordagem de uma narrativa baseada na sucessão de eventos ou na existência de um narrador. Eskelinen acredita que a componente ergódica e a componente narrativa podem surgir como conciliadas: "We already know that the ergodic side can coexist and be combined with traditional text types (argument, description and narrative)" (Eskelinen, 2012: 88). Porém, a conceção de texto como um todo inabalável e a ideia de narrativa como uma sequência lógica de eventos continuam a representar um obstáculo para a definição destes objetos textuais como literários.

Ryan referiu-se ao texto eletrónico como uma "massa indefinida" e não como um objeto discreto e por isso defende que "não é necessário ler a totalidade do texto" (Ryan, 2001: 47). Os textos aqui apresentados podem ser definidos como uma "massa indefinida" que, no entanto, apresentam características literárias e elementos narrativos ${ }^{143}$. Eles efetuam um aproveitamento expressivo do meio,

\footnotetext{
${ }^{143} \mathrm{Em}$ todos os textos pertencentes à literatura eletrónica é possível rastrear categorias e procedimentos desenvolvidos dentro da literatura. Porém, a literatura eletrónica também faz uso de recursos expressivos produzidos dentro das artes visuais, performativas ou jogos de computador. A hibridez manifestada por muitas obras de literatura eletrónica, onde a primazia não é dada à palavra, impede a sua definição como parte da literatura, porque esta encontra-se profundamente ligada ao texto verbal.
} 
veiculam mensagens e catalisam a emergência de significado(s). Eles não são um leque de oportunidades de interação, mas um vasto território onde o significado prospera e desafios teóricos surgem a todo o momento.

No caso dos textos interativos, é normalmente definido que a quantidade de tarefas propostas ao leitor interrompe a perceção de uma narrativa. Porém, para Ryan, isto não significa que a narratologia deva ser abandonada:

I regard narratology as an unfinished project, and if classical narratology fails the test of interactive textuality, this does not necessarily mean that interactive textuality fails the test of narrativity. It rather means that narratology must expand beyond its original territory. (...) the development of a digital narratology will be a long-term collaborative project, and I can only sketch here what I consider to be its most urgent concerns. (Ryan, 2006: 98)

O aparecimento de novos tipos de textos ${ }^{144}$ força os limites do conceito de literatura. Face à emergência destes textos ou de novas tecnologias de escrita e leitura, Eskelinen constata, tal como Ryan, que existe a necessidade de expandir a ação da narratologia. Carlos Reis referiu-se ao campo literário como um "vasto domínio de fronteiras algo fluídas" (Reis, 1997: 21). Os conceitos criados dentro dos estudos literários estão em permanente mutação. A definição de narrativa não se encontra circunscrita. Como frisarei nas próximas linhas, este é

\footnotetext{
${ }^{144}$ Scott Rettberg identificou os seguintes (novos) textos na área da literatura eletrónica: "hypertext fiction (both early works published on CD and published on the Web), literary text installations and CAVE works, ludic works that involve the conventions of games, kinetic poetry, interactive fiction, interactive drama, email narrative, visual poetry and works that reference the concrete poetry tradition, works that harvest and integrate texts from the web, poetry generators, a locative narrative, and works that emphasize aspects of user interaction" (Rettberg, 2013: 25).
} 
um conceito flexível, que pode ser adaptado a diferentes contextos e tipos de texto, e não apenas a uma sequência coerente de eventos narrados que culminam num desfecho.

\section{Significado emergente}

O funcionamento do computador tem um impacto na forma como os textos são apresentados ao leitor. O meio, ou o formato em que o texto é apresentado, não surge apenas como um suporte que canaliza a informação, mas como um elemento que contribui decisivamente para a formulação de significado. Segundo Wolfgang Iser, os textos ficcionais têm uma "conectividade" que é interrompida por espaços em branco. Estes são preenchidos pelo leitor através de "decisões seletivas" e correspondem a inúmeras possibilidades de sentido (Iser, 1994: 286). É através do estabelecimento de associações, ou "alien associations" (Pater, 1994 apud Iser: 206), e da exploração da possibilidade de sentido que o leitor compreende um texto. Num texto digital ou num cibertexto, o leitor tem de lidar com a imprevisibilidade dos textões. Estes são invocados por si, mas o leitor não chega a conhecer esta cadeia de sinais. Quando surgem no ecrã, os textões já foram transformados em escritões. Esta característica mantém um texto digital num estado permanentemente potencial.

Segundo Zumthor, os espaços em branco "constituem um espaço de liberdade ilusório" que apenas pode ser ocupado temporalmente. Para Zumthor, o sentido tem uma "existência transitória e ficcional" (Zumthor, 2007: 54). Para além disso, cada leitor pode "concretizar" o mundo ficcional de diferentes formas. Ryan identificou a hipótese de existir um texto diferente para cada leitor: "filling in of gaps and places of indeterminacy that can take a highly personal form, since every reader completes the text on the basis of a different life experience and internalized knowledge" (Ryan, 2001: 44). A mesma 
autora, associando-se a David Lewis, sugeriu a possibilidade de existência de "uma pluralidade de mundos textuais" (Ryan, 2001: 44). Philippe Bootz defende que um texto eletrónico pode dividir-se em dois: o texte-auteur e texte-à-voir. O primeiro apenas está ao alcance do autor, enquanto o segundo tipo de texto permanece virtual. Já o texte-à-voir é apenas visível para o leitor, mas o texte-auteur (ou a intenção do autor) permanece oculto (Bootz, 2006: 4). Segundo Bootz, existe uma "cesura semiótica" entre ambos: "There exists, then, a "semiotic gap" (...) which comes out from the loss of visibility of the intention of the author. The "texte-à-voir" reveals an intentionality that is its own and adapted and that may differ greatly from that of the 'texte-auteur'." (2006: 4). Esta descrição apresentada por Bootz permite constatar que o texto a que o leitor tem acesso pode ser distinto daquele criado pelo autor ${ }^{145}$.

Ryan salienta que, para Lévi, o virtual como potencial "não só representa o modo de existir do texto literário, mas também o estado ontológico de todas as formas de textualidade” (Ryan, 2001: 45). Após ser escrito, o texto permanece num estado virtual até ser despertado pelo leitor. Ele não é concretizado apenas através da interpretação, mas também por intermédio de uma simulação efetuada pelo leitor, através da imaginação:

In the case of texts, the process of actualization involves not only the process of "filling in the blanks" described by Iser but also simulating in imagination the depicted scenes, characters, and events, and spatializing the text by following the threads of various thematic webs, often against the directionality of the linear sequence. (Ryan, 2001: 45)

\footnotetext{
${ }^{145}$ Tal como Bootz, Ryan considera que existe um texto "como uma coleção de sinais escritos pelo autor" e o "texto construído mentalmente pelo leitor". Porém, entre ambos, existe um outro texto: o texto presente no ecrã (Ryan, 2001: 46).
} 
Para Ryan o texto já é um espaço virtual, mas a tecnologia eletrónica deixa entrever uma nova faceta: "the marriage of postmodernism and electronic technology, by producing the freely navigable networks of hypertext, has elevated this built-in virtuality to a higher power" (2001: 45-46). Citando Lévi, Ryan refere que o hipertexto é uma "matriz de textos potenciais". De facto, a estrutura hipertextual transmite a impressão de um texto gerado a todo o momento, que pode ser percorrido infinitamente. Tendo em conta que a literatura eletrónica dispõe de uma base de dados e da velocidade de processamento do computador, essa impressão poderá ser largamente intensificada.

The Jew's Daughter (2000-2006) de Judd Morrissey é uma narrativa recombinante cujo texto surge apresentado numa página em branco. À medida que o leitor coloca o cursor sobre a mancha gráfica, descobre que existem palavras que desaparecem e dão lugar a outras. O texto reformula-se indefinidamente, oferecendo novas possibilidades de significação. Contudo, nem todos os textos digitais apresentam uma possibilidade generativa como aquela manifestada por esta obra. De facto, ainda que expressem o contrário (isto é, ainda que se apresentem como infinitos), estes são estruturalmente finitos, justamente porque partem de uma base de dados com um número limitado de elementos ${ }^{146}$. A imaginação, coadjuvada pelo ato interpretativo, poderá expandir o potencial de um texto, tecendo associações improváveis durante a leitura ${ }^{147}$, ou posteriormente, através de apropriações ou

\footnotetext{
${ }^{146}$ Existem obras que partem, não de uma base de dados, mas, por exemplo, de informação recolhida online. Estas obras, embora possam alterar-se a cada visita, estão também cingidas ao programado pelos seus autores. A título de exemplo, a obra poética The Deletionist (2013), criada por Amaranth Borsuk, Jesper Juul e Nick Montfort, reduz páginas visitadas a um conjunto de palavras-chave para gerar um novo poema. Embora as palavras sejam substituídas por outras a cada visita, a estrutura e comportamento desta obra permanecem inalterados.

${ }^{147}$ No entanto, durante o contacto com o texto, este permanece restrito à sua arquitetura, a qual é pré-determinada e circunscrita ao tempo reservado para lê-lo ou ao número de elementos que podem ser configurados ou explorados. Neste sentido, o ato de abandonar o texto é a única decisão ou poder verdadeiramente oferecido ao leitor.
} 
releituras do mesmo. John Gibson identificou uma colaboração entre leitor e autor executada através da imaginação:

Literary works generate (...) the fictional worlds they inhabit in tandem with the reader, by presenting their language as in effect a recipe for the imagination. It is through this that a text that would otherwise remain a continuous string of empty representations is given substance. (Gibson, 2007: 131)

Para além de um esforço ergódico ou não-trivial, já aqui descrito, gostaria de chamar a atenção para a existência de um esforço imaginativo que se encontra dependente da suspensão de descrença para reconstruir um evento ou situação através da imaginação, que permite ao leitor encarnar (ou manter contacto com) personagens e especular acerca de uma possibilidade. Este permite igualmente manter o contacto com o mundo ficcional. O esforço imaginativo está ainda ligado à interpretação ${ }^{148}$ e impede que o texto interativo se torne num centro de operações executadas pelo leitor.

Segundo Hayles a literatura eletrónica surge da incapacidade de o computador lidar com a ambiguidade e plurissignificação (o código binário apenas permite a decisão entre 0 e 1). A "impiedade do código" é descrita por Hayles:

\begin{abstract}
Every voltage change must have a precise meaning in order to affect the behavior of the machine; without signifieds, code would have no efficacy. (...) every change in voltage must be given an unambiguous interpretation, or the program is likely not to function as intended. (...) Whatever messages on screen may say or imply, they are themselves generated
\end{abstract}

\footnotetext{
${ }^{148}$ A interpretação pode ser funcional e prática, ou seja, pode ser aplicada para interpretar o resultado de ações e melhorar a estratégia do leitor. Pode ainda focar-se nas estratégias figurativas do texto.
} 
through a machine dynamics that has little tolerance for ambiguity, floating signifiers, or signifiers without corresponding signifieds. (Hayles, 2005: 47)

Num texto digital, é a partir do código binário que o texto e a narrativa conquistam a sua plurissignificação. Entre o processador e o ecrã do computador é executada uma transformação: o código binário é transformado em imagens e palavras ou em código literário. Sendo assim, a ambiguidade e a proliferação do significado dependem da precisão da máquina: "Flexibility and the resulting mobilization of narrative ambiguities at a high level depend upon rigidity and precision at a low level (...) it is precisely the ability to build up from this reductive base that enables high-level literariness to be achieved" (Hayles, 2005: 53). O texto eletrónico parte da rigidez semântica do código binário (que apenas permite uma interpretação ou um significado) para as inúmeras possibilidades de significação.

Hayles referiu que a literatura eletrónica é gerada por um jogo entre "sequências sintagmáticas virtuais" e a "base de dados paradigmática" (2005: 54). De acordo com Pedro Barbosa, o programa Sintext é baseado na interseção entre o eixo paradigmático e o eixo sintagmático da linguagem. O eixo paradigmático é formado por elementos lexicais ou "Variantes" que são substituídos, a todo o momento, ao longo do eixo sintagmático, isto é, ao longo de uma "sequência parentetizada" ou "Constantes" (Barbosa, 5: 2000) que asseguram a geração do texto. Face a um texto eletrónico, o ato interpretativo começa na decisão entre 0 e 1. Só que esta ambivalência, aparentemente lacónica, pode gerar inúmeras possibilidades: "while they [computers] have no capacity for semantic recognition, the humans interpreting their results might see interesting patterns" (Hayles, 2008, 51). Sendo assim, o significado reside no processador num estado embrionário, mas depende do ser humano para ser materializado. 
Num texto ergódico, para que o significado possa ser constatado, o leitor tem de assumir várias funções. Aarseth distinguiu quatro funções do utilizador que poderão ser úteis para descrever a relação entre leitor e texto. No presente artigo, a referência a essas funções não tem como objetivo descrever o comportamento textual ou determinar o que é permitido ao leitor executar, mas identificar os procedimentos levados a cabo pelo leitor para compreender o texto. Estes encontram-se dependentes do esforço imaginativo e do ato interpretativo ${ }^{149}$.

Para Aarseth, a função interpretativa é exigida por todos os textos. Aqui gostaria de acrescentar que esta função é simultaneamente originada e origina todas as ações do leitor, pelo que é fundamental para aceder e compreender um texto. Para Aarseth, ao assumir a função exploratória, o leitor tem de escolher entre vários trilhos. No entanto, como nem sempre a exploração de um texto é executada através de uma decisão entre trilhos, esta função pode ser adaptada a outras formas de explorar o texto, como por exemplo, ouvir atentamente um excerto de narração; conhecer os diferentes ambientes que constituem a obra e rastrear ou apreciar os seus elementos expressivos. Para Aarseth, a função configurativa está relacionada com a escolha parcial ou criação de escritões. Já a função textónica surge associada à adição de textões de forma permanente. Como a criação de textões não se encontra ao alcance do leitor, pois estes terão sido pré-determinados, a função configurativa é aqui associada à forma como o leitor dispõe e organiza a informação de forma a proceder à leitura e interpretação de partes ou de todo o texto.

\footnotetext{
${ }^{149}$ A primazia oferecida à interpretação, a qual foi muitas vezes associada à tentativa de reduzir um texto a uma explicação inabalável, tem vindo a ser intensamente debatida. Gumbrecht referiu-se à intenção de o desconstrucionismo acabar com a "era do signo" (Gumbrecht, 2004: 53) e à tentativa de "destronar" a interpretação (5253). Aqui é defendido que o ato interpretativo, indelevelmente associado à tradição hermenêutica, não é uma forma de encontrar o significado uno de um texto, mas de multiplicar as suas possibilidades de significação. O ato interpretativo é igualmente visto como necessário para a compreensão de qualquer tipo de texto.
} 
O leitor age de acordo com a liberdade de escolha e de ação oferecida pelos criadores do texto e não pode colaborar na construção da obra, mas apenas reconstruí-la. Isto significa que a função textónica (que, segundo Aarseth implica adicionar "permanentemente" textões ao texto) teria de ser abandonada. Porém, os textões têm uma componente potencial e o leitor desconhece como eles emergem e que forma (ou significado) eles assumirão. Eles são catalisadores de mundos possíveis e a função textónica tem como objetivo encontrar a forma de despertar estes textões e desencadear esses mundos. O leitor leva a cabo um esforço imaginativo para especular sobre o que vem a seguir e para preencher espaços vazios. Para tal, o leitor tem de adotar a função textónica, ou seja, tem de criar e ajustar a sua estratégia para que os textões sejam transformados em escritões. Sendo assim, perante um texto interativo, dadas as funções assumidas pelo leitor, a emergência do significado depende de uma cooperação entre esforço ergódico e esforço imaginativo.

\section{Narrativas projetadas}

A obra La Disparue (2012) é um híbrido entre jogo e história policial que inclui o leitor como protagonista, ou melhor, como o detetive responsável por uma investigação. La Disparue é proposta como uma sequência de enigmas cuja resolução permite identificar o responsável pelo desaparecimento de Elisabeth Monohan e da morte de Kacey Harnois. Segundo Cécile Iran, Médéric Lulin e Sophie Séguin, os autores desta obra colaborativa, La Disparue é uma hiperficção. Esta história não está localizada apenas num sítio online, mas estende-se a diferentes espaços. Tal como é demonstrado ao longo da leitura de La Disparue, uma conta do Twitter ou do Facebook pode ajudar o leitor a obter mais informações para resolver o mistério. Um texto literário nem sempre corresponde à imagem de um romance ou a 
um texto publicado entre a capa e contracapa de um livro. Como sabemos, um texto literário pode assumir a forma de uma missiva ou de um fragmento (veja-se o caso do Livro do Desassossego). Para ler La Disparue, o leitor terá de reunir a informação dispersa por diversos locais, assumindo para isso a função exploratória e função configurativa. La Disparue pode ser definida como um processo que se estende a diferentes espaços em rede.

As histórias policiais em formato impresso são normalmente desenhadas para atingir um objetivo: alcançar o final da narrativa para descobrir a identidade ou localização do criminoso. Sendo assim, elas estão dependentes de uma estrutura aristotélica, ou seja, são construídas mediante uma lógica de início-meio-fim. La Disparue tem uma componente lúdica acentuada. Esta obra exige que o leitor vença vários desafios até ganhar o jogo ou descobrir a verdade, mas também é orientada para alcançar um desfecho (na verdade o leitor pode alcançar dois desfechos, conforme a sua performance). O desenrolar da narrativa depende da viagem exploratória executada pelo leitor.

O desejo de alcançar um desfecho está associado à sensação de concretização e de ordem restabelecida: espera-se que no final da história tudo seja revelado e que todas as questões do leitor sejam respondidas. Walter Ong considerou que as histórias policiais seriam um exemplo perfeito de estruturas baseadas na pirâmide de Gustav Freytag: "In the ideal detective story, ascending action builds relentlessly to all but unbearable tension, the climactic recognition and reversal releases the tension with explosive suddenness, and the dénouement disentangles everything totally" (Ong, 1982: 147). Schäfer e Gendolla referem que as histórias policiais inscritas no meio digital substituem a produção de suspense pelo desejo de superação de pequenos desafios (Schäfer e Gendolla, 2010: 97). Se o leitor/jogador não reunir as pistas deixadas pelos autores, não terá sucesso. Isto pode provocar uma espécie de tensão, tal como representada pela 
pirâmide de Freytag. Embora pareça que o leitor está envolvido na construção da narrativa (o leitor tem de visitar diversas páginas para recolher informação), a verdade é que o roteiro levado a cabo pelo leitor foi forjado pelos criadores de La Disparue. Poderá parecer que La Disparue é uma obra fragmentada, sem uma lógica interna, mas, na verdade, ela exibe uma estrutura episódica que corresponde às diferentes etapas da investigação/níveis do jogo. Apesar de propor várias tarefas situadas em diversos locais na rede, esta história policial manifesta uma coerência narrativa e não inviabiliza o alcance de um desfecho. Em La Disparue existe uma narrativa e uma lógica causal que é conhecida pelo leitor através da resolução de enigmas e superação de desafios.

O leitor de uma história policial impressa é igualmente um investigador porque coloca hipóteses e imagina cenários através das pistas deixadas pelo autor. Em La Disparue, o leitor é convidado a investir um esforço ergódico que o leva a explorar e configurar o texto até conhecer o paradeiro de uma das vítimas (ou alcançar a resolução do mistério). A história não é veiculada unicamente através de um texto verbal, mas também através de ficheiros, fotos, trilhos, provas ou pistas distribuídas por diversos locais. La Disparue é uma narrativa projetada porque o leitor terá de recolher diferentes elementos para conseguir uma versão aproximada desta.

Para conhecer os diferentes espaços de La Disparue (ou, para ler esta obra), o leitor terá de ativar uma função explorativa. Num momento inicial, o leitor é apresentado a uma secretária sobre a qual foram espalhados vários objetos. É através da exploração deste espaço, mas também através da sua configuração, que o leitor reúne algumas informações valiosas sobre si (a sua carteira e documentos pessoais pertencem à miscelânea de objetos dispostos sobre a mesa), acerca da aparência da vítima e do passo a dar em seguida. Para além do esforço ergódico investido pelo leitor, ele é também convidado a assumir um esforço imaginativo (afinal de contas, ele é 
o investigador responsável e a vida de Elisabeth Monohan depende da sua performance enquanto detetive, leitor e jogador). O leitor é encorajado a projetar diferentes cenários e a especular sobre o que terá acontecido.

Joseph Tabbi referiu-se à necessidade de pensar para além da "narrativa". Em vez desta, este autor mencionou a existência de "pistas" e "sugestões" (Tabbi, 2011: 3). Porém, a narrativa encontra-se enraizada no discurso dedicado à literatura eletrónica. Apesar de volátil e impreciso, este termo permeia consecutivamente o discurso sobre criação literária. Eskelinen afirmou que a ficção hipertextual, tal como alguma ficção pós-modernista, é potencialmente narrativa. Calleja referiu-se a uma narrativa experiencial, ou seja, uma narrativa que é formada na mente do leitor ao longo do jogo, através de "elementos representacionais e das nossas representações subjetivas" (Calleja, 2011: 119). Em vez de uma anti-narrativa ou de uma narrativa sabotada ou relutante, Aarseth referiu-se a afternoon: a story (1987-1990) ${ }^{150}$ como um "jogo de narração". Este autor considera que certos elementos da narrativa podem ser usados, mesmo sem a intenção de transmitir uma história ${ }^{151}$ (Aarseth, 1997: 94). Todos estes autores se referem a uma narrativa subentendida, eminente ou em formação que pode ser apresentada (ou suscitada) ao longo da leitura. Aqui pretendo sugerir a existência de uma narrativa projetada, que reside na memória do computador e que é despertada, quer através das funções assumidas pelo leitor, quer através de processos programados. Esta narrativa parece inexistente, mas é possível constatar vários vestígios da sua presença. A leitura desta narrativa torna-se assim num escrutínio dos seus elementos fundamentais que, quando reunidos, podem não produzir uma história, mas permanecer como meros alicerces do que seria uma narrativa.

\footnotetext{
${ }^{150}$ Esta obra é considerada por inúmeros autores como a primeira hiperficção eletrónica. ${ }^{151}$ Aarseth considera que as ações levadas a cabo durante um jogo não são narrativas nem constituem uma história, embora representem uma sucessão de eventos (Aarseth, 1997: 94).
} 
A condição provisória de uma narrativa projetada pode ser vislumbrada no jogo The Stanley Parable (2011-2013). Este é apresentado pelos seus criadores como uma "exploração de história, jogo e escolha”. Na página que dá acesso a este jogo, é colocado um desafio: "the story doesn't matter, it might not even be a game, and if you ever actually do have a choice, well let me know how you did it". Uma parábola é uma pequena narrativa que tem uma componente didática. De facto, o jogo parece recordar permanentemente ao leitor que o seu poder de escolha é ilusório. Neste jogo, o jogador é tratado como um peão que, tal como Stanley (o protagonista), tem de pressionar botões e obedecer a diretivas. $\mathrm{O}$ jogo exige que o leitor assuma constantemente uma função explorativa (este conhecerá inúmeros espaços e percorrerá diversos corredores em busca da história); uma função configurativa (premir botões e abrir portas são atividades constantemente exigidas) e uma função textónica (o leitor terá de tecer estratégias para alcançar o próximo nível ou ativar mais um trecho de narração).

No início do jogo, surge uma faixa onde é repetida a frase "The end is never the end". A parábola de Stanley é um jogo que faz uso da ironia para refletir sobre a própria estrutura e funcionamento. The Stanley Parable (que terá sido criado como uma ficção interativa e só depois assumiu a forma de um jogo) recorda as hiperficções multilineares e autorreflexivas do período clássico da literatura eletrónica. A sua estrutura episódica e multilinear assemelha-se ao texto identificado por Lev Manovich, o texto enquanto base de dados:

After the novel, and subsequently cinema privileged narrative as the key form of cultural expression of the modern age, the computer age introduces its correlate - database. Many new media objects do not tell stories; they don't have beginning or end; in fact, they don't have any development, thematically, formally or otherwise which would organize their elements 
into a sequence. Instead, they are collections of individual items, where every item has the same significance as any other. (Manovich, 2001: 8)

Esta parábola invoca um sentimento de estranheza porque a barreira entre jogo e narrativa autorreflexiva não é clara. A parábola de Stanley está ligada à literatura através de um constante desafio a alguns dos seus pressupostos. The Stanley Parable brinca com os limites da ficção e desafia a noção de lógica, coerência, verosimilhança e desfecho. A função interpretativa é constantemente invocada, não só porque o leitor se encontra perante um jogo e necessita de interpretar e avaliar o resultado das suas ações para melhorar ou estabelecer a sua estratégia, mas porque esta parábola está repleta de enigmas teóricos e referências literárias.

Stanley é um funcionário de uma empresa que um dia abandona o seu posto de trabalho para descobrir o motivo de uma falha técnica. Quando o faz, a aleatoriedade toma conta da sua vida. Assim que abandona o seu computador, descobre que o edifício onde trabalha foi evacuado. A missão de Stanley (e do jogador) é descobrir o que terá acontecido ou "a história”, o que resulta numa aventura metalética que mostra ao leitor elementos de uma narrativa, mas que boicota constantemente a formação de uma história. Stanley é apresentado por um narrador (Kevan Brighting) que o acompanha durante o percurso. Existe uma cena em que a voz do narrador descreve os sentimentos de Stanley (que é personificado pelo leitor) mas, a dado momento, a voz simula um estado de loucura e faz com que Stanley (ou o jogador) se atire de um prédio. O jogador é apresentado ao seu avatar que jaz inerte na rua. Enquanto isso, a voz centra-se numa outra personagem. Nesse momento, o narrador usa a expressão “This is a story about...". Porém, The Stanley Parable não é uma história sobre uma personagem. Ao assumir o papel de narrador, descrevendo os sentimentos e ações de Stanley ou contando a história da outra 
personagem, o sistema parece entrar em conflito. Reiniciar o jogo é a única solução encontrada pelo narrador.

A parábola de Stanley é constituída por um narrador, personagens e eventos (ou pelos mesmos elementos que constituem uma narrativa), mas a sua história não é conhecida. O esforço ergódico investido pelo jogador (ou a sua participação como personagem) não está na origem deste estado latente da narrativa. A formação de uma narrativa coerente já terá sido interrompida antes da intervenção do jogador, graças ao teor metaficcional assumido pelos autores desta parábola. The Stanley Parable não pretende transmitir uma história, mas uma ideia de narrativa ou um conjunto de características associadas a esta forma de representar eventos.

Para que o leitor não se perca, o narrador inclui, a dado momento, linhas amarelas ao longo dos corredores. Porém, o próprio narrador perde frequentemente o rumo da narrativa. As linhas desenhadas pelo narrador sobem paredes e percorrem o teto, o que resulta numa visão escheriana da estrutura da narrativa e da arquitetura do jogo. O narrador acaba por ter de pedir ao jogador para esquecer as linhas e para escrever a história (ou forjar o destino da personagem) e escolher um caminho diferente, "sem linhas, nem monitores”. O jogo apela à participação criativa do jogador. Para manter esta ilusão, o leitor tem de investir um esforço imaginativo. Sem reduzir a sua descrença - uma condição fundamental em textos interativos em que o leitor tem de assumir o papel de personagem - e sem compactuar com o narrador (ainda que este não seja fiável), o leitor não pode continuar em jogo. Nesta parábola, o narrador não é omnisciente e exibe algumas dificuldades em acompanhar o rumo da história. Isto acontece porque The Stanley Parable é uma narrativa projetada através do desafio das suas próprias fundações.

Os conflitos entre a escolha do leitor e as indicações do narrador são colmatados através do comportamento excêntrico deste. 
A voz da parábola de Stanley autointitula-se de narrador. Ela oferece indicações ao leitor como se fosse uma voz que emergisse de um romance. Em The Stanley Parable, uma estreita ligação com a literatura é concretizada a todo o momento. Na presente frase, o narrador recorre à terceira pessoa do singular: "Stanley escolheu a porta da esquerda". Porém, como é possível concluir durante o jogo, esta voz não corresponde à imagem de um narrador convencional ${ }^{152}$. Aarseth sublinhou que nos jogos de aventura ou de ficção existe um plano de negociação. Eskelinen frisou que, nos textos ergódicos, existe a presença de um "negociador", e não de um "narrador". (Aarseth, 2012 apud Eskelinen, 2012: 203). Segundo Aarseth, a intriga ergódica tem lugar num nível extraficcional e é direcionada contra o utilizador. Este, de acordo com Aarseth, "tem de descobrir por si próprio o que se está a passar". O utilizador implícito negoceia com uma voz ergódica ou um "correspondente simulado que relata os eventos ao utilizador". Segundo Eskelinen, a voz ergódica é um "negociador" e não um contador de histórias ou um narrador (Eskelinen, 2012: 204). A voz poderá fornecer informação, mas poderá também surgir como oponente do leitor. Eskelinen descreve a sua função da seguinte forma: "the voice's discontinuous narrations and descriptions serve by both distracting the user and giving him the information he needs to solve the puzzle" (2012: 204). A voz ergódica em The Stanley Parable surge como oponente ou como adjuvante, mas o puzzle fica por resolver. Em vez de uma história, esta parábola propõe uma aventura metaficcional.

Patricia Waugh definiu a metaficção como uma "escrita ficcional que auto-conscientemente e sistematicamente chama a atenção para a sua condição de artefacto, a fim de colocar questões sobre a

\footnotetext{
${ }^{152}$ De facto, o narrador poderá ser omnipresente, mas como é por vezes surpreendido pela audácia ou insolência do jogador, não é omnisciente. O narrador desta parábola é ainda bidiegético (Eskelinen), ou seja, pode alternar entre homodiegético e heterodiegético.
} 
relação entre ficção e realidade" (Waugh, 1996: 2). Sendo assim, a metaficção efetua uma crítica do próprio processo de construção. Esta característica é visível em The Stanley Parable, onde as "estruturas fundamentais da ficção narrativa" são exploradas.

A voz do narrador, que recorre à linguagem literária ${ }^{153}$, bem como os dilemas resultantes da sua ineficácia em acompanhar o rumo da narrativa, produzem um exercício estético. Os textos gerados a cada momento (a narração é acompanhada por legendas) parecem estar na base do sucesso alcançado por The Stanley Parable. Após consultar fóruns e reviews dedicados a este jogo torna-se claro que os jogadores não aderem a este jogo por causa de uma promessa de ação, mas pela forma como esta parábola é veiculada ${ }^{154}$.

Numa das páginas de recensões escritas por jogadores de videojogos intitulada Hardcoregamer, é possível ler a seguinte opinião: "The writing is smart and the narration is excellent, so much so that I usually found myself stopping any time the narrator had something to say just to make sure I didn't miss anything" (Cunningham, 2013). Segundo o autor desta opinião, The Stanley Parable é um jogo de "interatividade limitada", "cujo valor está na descoberta e na experimentação”. The Stanley Parable é constituído por gráficos rudimentares e monótonos e não oferece a mesma intensidade de um jogo de ação. Este jogo não permite ao leitor exibir a sua perícia e técnica. The Stanley Parable é um desafio intelectual que projeta a ilusão de uma narrativa. Esta parábola é constituída por personagens (ainda que fugazes), pelo jogador/protagonista e um narrador. Ela oferece momentos de leitura e audição, mas o seu narrador não consegue veicular uma história. A estrutura de uma narrativa é revelada ao

\footnotetext{
${ }^{153}$ Aqui associa-se a linguagem literária ao uso da terceira pessoa, à prática de descrições longas de uma ação através de um registo formal e a uma escolha cuidada de vocabulário.

${ }^{154}$ Os gráficos também não são um elemento atrativo em The Stanley Parable. Na verdade, a monotonia e a natureza rudimentar dos seus cenários parecem funcionar como um elemento desencorajador.
} 
longo deste jogo. No entanto, o conteúdo dessa narrativa, ou a história, não chega a ser conhecida. Ao edifício da narrativa falta a história. Os seus corredores permanecem vazios e o leitor apenas tem acesso ao que potencialmente poderia ser uma narrativa.

\section{Considerações finais}

Dado o seu carácter híbrido, metaficcional e, porque solicitam um investimento ergódico por parte do leitor, muitas obras parecem oferecer um ambiente inóspito, onde dificilmente uma narrativa poderia prosperar. Esta é vista como dependente de um tecido coerente de eventos e as obras ergódicas podem colocar desafios ao leitor que canalizam a atenção deste para a exploração e configuração do texto. Porém, esses desafios não se limitam ao desenvolvimento destas atividades. Uma obra ergódica é, frequentemente, a origem de enigmas teóricos que envolvem o leitor numa reflexão acerca do ato de leitura, do processo de escrita e acerca da própria literatura. Por vezes, uma história é substituída por (ou surge geminada com) a transmissão de uma ideia ou de um desafio que se refere ao próprio texto. A narrativa, justamente porque é um conceito flexível, mas que contém características que funcionam como elementos distintivos (tais como a existência de personagens, narrador ou sequência de eventos) continua a surgir no discurso dedicado à ficção digital ou ao estudo dos jogos. É justamente esse ato de projetar uma narrativa através dos seus elementos fundamentais que foi captado por este artigo.

A materialidade do texto eletrónico, que se estende do disco rígido até à forma como o significado pode emergir no ecrã, tem uma função primordial na transmissão de uma narrativa. A assimetria entre o plano textónico e escriptónico e a radicação do significado ao nível do processador - e não apenas ao nível do ecrã ou ao nível do que é visualmente percetível pelo leitor - fazem com que a noção de volatilidade do significado ganhe novos contornos. Entre 
o autor e o leitor reside a máquina e, apesar de todo o empenho investido para torná-la cada vez mais neutra e transparente, a sua presença adquire uma expressividade particular em obras de literatura eletrónica. Ainda que o leitor tenha de juntar as peças de um puzzle ou reconstruí-la a partir de sombras e espectros, a narrativa continua a perseverar. Formada entre textões e escritões, ela pode assumir uma forma inusitada quando alcança a superfície do ecrã. Embora ela possa parecer inexistente, a sua presença é frisada ao longo de toda a leitura.

\section{REFERÊNCIAS BIBLIOGRÁFICAS}

AARSETH, E. (1997). Cybertext: Perspectives on Ergodic Literature. Baltimore: The John Hopkins University Press.

ALEXANDER, B. (2011). The New Digital Storytelling: creating narratives with new media. Santa Bárbara, Califórnia: ABC-CLIO, LLC.

ASCOTT, R. (2002). "Is there love in the telematic embrace?" [1990], in Multimedia: from Wagner to virtual reality. Eds. Packer, Randall e Ken Jordan. Nova Iorque: W. W. Norton \& Company Ltd., 333-344.

BARBOSA, P. (1996). "Ângulos e virtualidades do Texto Virtual", in Teoria do Homem Sentado. Porto: Edições Afrontamento. Também disponível em: http://po-ex. net/taxonomia/transtextualidades/metatextualidades-alografas/pedro-barbosa-literatura-teoria-homem-sentado-parte1, consultado a 2 de Setembro de 2015. BARBOSA, P. e TORRES, J. M. (2000). O Motor Textual. Livro Infinito. Porto: Edições Universidade Fernando Pessoa. Também disponível em: http://www.po-ex.net/ taxonomia/transtextualidades/metatextualidades-autografas/pedro-barbosa-o-motor-textual-livro-infinito, consultado a 2 de Setembro de 2015.

BELL, A. (2009). The Possible Worlds of Hypertext Fiction. Londres: PalgraveMacmillan.

BENJAMIN, W. (2003). Das Kunstwerk im Zeitalter seiner technischen Reproduzierbarkeit. Frankfurt am Main: Suhrkamp Verlag. 
BOOTZ, P. (2006). "Digital Poetry: From Cybertext to Programmed Forms”, in Leonardo Electronic Almanac, Vol. 14 Issue 05 - 06, disponível em: http://www.leoalmanac.org/wp-content/uploads/2012/09/04Digital-Poetry-From-Cybertext-to-Programmed-Forms-by-Phillipe-Bootz-Vol-14-No-5-6-September-2006-Leonardo-Electronic-Almanac.pdf, consultado a 2 de Setembro de 2015.

CALlEJA, G. (2011). In-Game: From Immersion to Incorporation. Cambridge, MA: MIT Press.

CUNningham, J. (2013). "Review: The Stanley Parable", in Hardcoregamer, disponível em: http://www.hardcoregamer.com/2013/10/17/review-the-stanley-parable/58895/, consultado a 2 de Setembro de 2015.

ESKELINEN, M. (2012). Cybertext Poetics: The Critical Landscape of New Media Literary Theory. Nova Iorque: Continuum.

FERRET, T. (2008). The Fugue Book, in Electronic Literature Collection, vol. 1, disponível em: http://collection.eliterature.org/2/works/ferret_fugue_book.html, consultado a 2 de Setembro de 2015.

GENETTE, G. (1972). "Discours du récit: essai de méthode”, in Figures III- Collection Poétique. Paris: Éditions du Seuil.

GIBSON, J. (2007). Fiction and the Weave of Life. Oxford: Oxford University Press.

GUMBRECHT, H. U. (2004). Production of Presence: What Meaning Cannot Convey. Stanford: Stanford University Press.

HAYLES, N. K. (2005). My Mother Was a Computer: Digital Subjects and Literary Texts. Chicago: University of Chicago Press.

HAYLES, N. K. (2008). Electronic Literature: New Horizons for the Literary. Notre Dame: University of Notre Dame,

HOWELL, B., Sabrina Small e Jonathan Kemp (2010). exquisite_code (projeto), disponível em: http://exquisite-code.com/.

IRAN, C., Médéric Lulin e Sophie Séguin (2012). La Disparue, in Revue de Littérature Hypermédiatique Bleu Orange, disponível em: http://revuebleuorange.org/ bleuorange/05/iran_lulin_seguin/, consultado a 2 de Setembro de 2015.

ISER, W. (1994). Der Akt des Lesens. München: Wilhelm Fink Verlag.

MANOVICH, L. (2001). The Language of New Media. Cambridge, Massachusetts: MIT Press. 
MARINO, M. C. (2013). “Reading exquisite_code: Critical Code Studies of Literature”, in Comparative Textual Media. Eds. N. Katherine Hayles e Jessica Pressman, 283-309. MORRISSEY, J. (2006). The Jew's Daughter [2000], Electronic Literature Collection, vol. 1, in http://collection.eliterature.org/1/works/morrissey_the_jews_daughter. html, consultado a 31 de Julho de 2014.

ONG, W. J. (1982). Orality and Literacy: the technologizing of the word. Nova Iorque: Methuen \& Co.

RALEY, R. (2001). "Reveal Codes: Hypertext and Performance", in Postmodern Culture, vol. 12, 1, disponível em http://muse.jhu.edu/journals/postmodern_culture/ v012/12.1raley.html, consultado a 2 de Setembro de 2015.

REIS, C. (1997). O Conbecimento da Literatura: Introdução aos Estudos Literários. Coimbra: Livraria Almedina.

RETTBERG, S. (2013). “An Emerging Canon? A Preliminary Analysis of All References to Creative Works in Critical Writing Documented in the ELMCIP”, disponível em (página autor): http://retts.net/documents/Emerging_Canon_S_Rettberg. pdf, consultado a 2 de Setembro de 2015.

RYAN, M. L. (2001). Narrative as Virtual Reality: Immersion and Interactivity in Literature and Digital Media. Baltimore: Johns Hopkins University Press.

RYAN, M. L (2006). Avatars of Story. Minneapolis, MN: University of Minnesota Press. SCHÄFER, J. (2007). "The Gutenberg Galaxy Revis(it)ed", in The Aesthetics of Net Literature: Writing, Reading and Playing in Programmable Media. Eds. Peter Gendolla e Jörgen Schäfer. Bielefeld: Transcript Verlag, pp. 121-160.

SCHÄFER, J. e Peter Gendolla, (2010). "Reading (in) the Net: Aesthetic Experience in Computer-Based Media", in Reading Moving Letters: Digital Literature in Research and Teaching, A Handbook. Eds. Simanowski, Roberto, Jörgen Schäfer e Peter Gendolla. Bielefeld: transcript Verlag, pp. 81-108.

TABBI, J. (2010). "Introduction to Focus: Cognitive Fictions - Cognition against Narrative”, in American Book Review, Vol. 31, 6, Setembro/Outubro, disponível em: http://americanbookreview.org/issueContent.asp?id=190, consultado a 2 de Setembro de 2015.

TABBI, J. (2011). "Cognitive science", in Routledge Companion to Literature and Science. Eds. Clarke, Bruce e Manuela Rossini. Nova Iorque: Routledge, 77-88. 
WAUGH, P. (1996). Metafiction: The Theory and Practice of Self-conscious Fiction. Nova Iorque: Routledge.

WREDEN, D. e William Pugh (2013). The Stanley Parable, disponível em: http://www. stanleyparable.com/, consultado a 2 de Setembro de 2015.

ZUMTHOR, P. (2007). Performance, Recepção e Leitura. São Paulo: Cosac Naify. 
(Página deixada propositadamente em branco.) 


\title{
NARRATIVAS EM MUDANÇA: DO FOLHETIM AOS TEXTOS TRANSMEDIA
}

\author{
Fernanda Castilho Santana
}

Universidade de São Paulo

ECA/USP-CIMJ

\section{Introdução}

O reconhecimento da importância simbólica das narrativas artificiais $^{155}$ para a existência humana é uma ideia defendida por Umberto Eco que vem sendo fortemente empregada na literatura dedicada ao estudos das narrativas materializadas em diferentes suportes expressivos. As histórias de ficção, que encontram no meio audiovisual um caminho para alcançar os seus leitores, também assentam nessa premissa do fascínio por aquilo que permite "[...] exercer sem limites as nossas faculdades, quer para percebermos o mundo, quer para reconstruirmos

\footnotetext{
${ }^{155}$ Umberto Eco distingue narrativas naturais e narrativas artificiais, classificando as primeiras como relatos de acontecimentos reais (por exemplo, as narrativas jornalísticas), e as segundas como histórias de ficção, relatos que "fazem de conta que dizem a verdade sobre o universo real" (Eco, 1997:126). No entanto, é importante considerar que entre esta dicotomia reside uma linha ténue. "Na ficção narrativa, misturam-se de tal maneira referências precisas ao mundo real que, depois de ter passado algum tempo no mundo do romance e misturado elementos ficcionais com referências à realidade, como é natural, o leitor deixa de saber ao certo onde se encontra. Este estado dá origem a fenómenos bem conhecidos. O mais comum é quando o leitor projeta o modelo ficcional sobre a realidade - por outras palavras, quando acaba por acreditar na existência real de personagens e acontecimentos ficcionais." (Eco, 1997: 131).
} 
o passado" (Eco, 1997: 138). Assim, estruturamos a nossa experiência através destas histórias que operam como receptáculo das nossas paixões, mas, sobretudo, estão na base da construção e afirmação das nossas identidades, desde os tempos mais remotos (Costa, 2000). Desta forma, concordamos com a posição de Cristina Castilho Costa, na sua análise sobre a natureza e a importância das narrativas no nascimento da cultura e as suas implicações no imaginário, quando refere a necessidade, inerentemente humana, de organização mental dos acontecimentos em forma de história com passado, presente e futuro como contribuição para a consciência da finitude da vida ${ }^{156}$. Por isso, o ato de narrar é pertença de todas as épocas e sociedades (Nogueira, 2010: 64), componente necessário para a construção da identidade, tanto individual, como coletiva, pois "[...] ser para o homem é ter uma história, é integrar durações e temporalidades" (Costa, 2000: 41).

Talvez por estas razões históricas, filosóficas, psicológicas e sociais definidas por diversos autores (Eco,1997; Costa, 2000; Nogueira, 2010; Rose, 2011), o apreço pelas narrativas desponte naturalmente durante a infância, quando atentamos para os pormenores das histórias que estimulam a expansão do nosso imaginário através das aventuras e delírios das personagens. A receção destas primeiras narrativas de ficção transporta-nos para cenários imaginários e desperta a nossa tendência de construir a vida como um romance (Eco, 1997: 135). Tanto na infância, como na vida adulta, a ficção encerra uma função lúdica, tal como os jogos, ao criar um simulacro de situações possíveis (Eco, 1997). No âmbito destas reconstruções do real através da ficção, o ato narrativo

\footnotetext{
${ }^{156}$ De acordo com Cristina Castilho Costa, os grupos humanos encontraram nas narrativas uma forma de temporalizar o quotidiano, organizando a realidade vivida por meio da memória e da projeção. "As narrativas são maneiras de realizar e de expressar nossa temporalidade, tornando-a tão objetiva quanto a certeza de nossa finitude e transitoriedade. [...] Assim, as estruturas narrativas são formas de estabelecer modulações e durações, arquitetanto a temporalidade humana." (Costa, 2000: 41). Desta forma, os grupos humanos criaram formas de expressão como os rituais para revelar os mitos e procurar explicações para as suas inquietações, em especial o entendimento perante o inexorável.
} 
engloba uma relação que é, ao mesmo tempo, dicotómica, interdependente, fluída e simbólica, entre o narrador e o ouvinte (Costa, 2000; Rose, 2011). Como teremos a oportunidade de verificar ao longo do presente texto, esta relação entre texto e leitor, profundamente estudada pelas correntes da teoria literária ${ }^{157}$, modifica-se no decorrer dos tempos de acordo com os suportes de materialização das narrativas.

Conforme indica Maria Parecida Baccega, através das palavras de Milly Buonanno, o termo narrativa vem sendo empregado de forma alargada para designar qualquer configuração de história, desde “[...] a pintura rupestre à poesia épica, às obras teatrais, aos diversos gêneros de prosa literária; da narração cinematográfica, aos quadrinhos e aos desenhos animados [...]" (2012: 1291). Segundo alguns autores (Genette, 1987; Nogueira, 2010), devido ao caráter ambíguo e polissémico do termo ${ }^{158}$, o emprego da palavra pode gerar confusões de fundo interpretativo. Como indicam as definições de Nogueira ${ }^{159}$, entendemos a narrativa como conjunto formado fundamentalmente pela história e pelo enredo (forma como se conta a história). Já na distinção entre o que se conta e o modo como se conta - outra

${ }^{157}$ O surgimento da narratologia - um campo específico dentro da teoria literária delineia o estudo científico das estruturas narrativas e marca uma fase importante para esta área, fundada ainda na antiguidade por Aristóteles e Platão. No início do século XX, Tzvetan Todorov fica conhecido como precursor dos estudos narratológicos, mas outros nomes constam como responsáveis pelo desenvolvimento da análise das narrativas como Roland Barthes, para além dos formalistas russos - movimento surgido na Rússia, do qual Todorov também fazia parte e cujos principais representantes são os teóricos Viktor Chklovski, Vladimir Propp, Roman Jakobson, entre outros (Booth, 2010: 89).

${ }^{158}$ Conforme Nogueira, etimologicamente, o termo narrativa deriva do sânscrito gnarus e significa conhecer ou dar a conhecer (2010: 63).

159 Nogueira, apesar de não citar Gérard Genette, distingue claramente três noções semelhantes às que o autor francês propõe: "Umas vezes é utilizada para designar o próprio ato da narração; outras, pode remeter para o conteúdo desse ato; é ainda entendida, muitas vezes, como modo do discurso" (Nogueira, 2010: 63). Neste sentido, vale mencionar os termos unívocos indicados por Genette para cada um dos aspetos da narrativa: "Proponho [...]denominar-se história o significado ou conteúdo narrativo (ainda que esse conteúdo revele, na ocorrência, de fraca intensidade dramática ou teor factual), narrativa propriamente dita o significante, enunciado, discurso ou texto narrativo em si, e narração o ato narrativo produtor e, por extensão, o conjunto da situação real ou fictícia na qual toma lugar" (Genette, 1987: 25). 
problemática do campo dos estudos literários - interessa-nos, fundamentalmente, uma terceira dimensão: as possibilidades de concretização de uma história num determinado dispositivo expressivo. Dito de outra forma, o nosso interesse recai no "(...) momento em que submetemos uma certa história a determinados dispositivos (oralidade, escrita, audiovisual, etc.) que a reconfiguram aquando da sua apresentação (...)" (Nogueira, 2010: 63). Esta reconfiguração das histórias, conforme o suporte, é, precisamente, o objeto de nosso interesse, pois, como indicam Carlos Reis e Ana Lopes, no Dicionário de Narratologia, não devemos ignorar o facto de “(...) a narrativa poder concretizar-se em suportes expressivos diversos, do verbal ao icónico, passando por modalidades mistas verbo-icónicas (banda desenhada, cinema, narrativa literária, etc.)" (2007: 271). Esta notável capacidade de migração adaptativa entre suportes expressivos tão distintos como da oralidade à comunicação mediada pelo computador (CMC), em certa medida pressupõe uma transfiguração que revela o caráter camaleónico das narrativas ${ }^{160}$.

\section{Os primórdios das narrativas televisivas de ficção}

Após esta brevíssima reflexão sobre a importância das narrativas para estruturação da nossa experiência identitária, transferimo-nos, agora, para a contemporaneidade, com o objetivo de apontar as origens do género que, há mais de trinta anos, vem incutindo no quotidiano dos portugueses uma dose de narratividade suficiente para o reencontro com seus sonhos, mitos e conflitos íntimos: a telenovela (Reis, 1995: 38).

\footnotetext{
${ }^{160}$ A ecologia mediática contemporânea constitui um ambiente privilegiado para o desenvolvimento e expansão das narrativas, como teremos a oportunidade de discorrer ao longo deste trabalho.
} 
$\mathrm{Na}$ literatura sobre a teleficção, tornou-se recorrente entre os autores, sobretudo no Brasil, a referência da telenovela como herdeira do romance-folhetim do século XIX. De facto, assim como apontam as publicações sobre o assunto (Ortiz et al., 1989; Meyer, 1996; Costa, 2000; Cunha, 2011), entre as quais destacamos o livro Folbetim de Marlyse Meyer (1996), a estruturação da história adotada pelo folbetim-eletrónico assenta na lógica narrativa dos romances publicados em série, no rodapé das primeiras páginas dos jornais impressos daquela época ${ }^{161}$. No rol de características semelhantes entre os dois formatos ficcionais, inscrevem-se: a adequação ao princípio da seriali$\mathrm{dade}^{162}$, por vezes associado aos recursos narrativos como o gancho $^{163}$; a organização como obra aberta que permite certa interatividade dos leitores e, consequentemente, pode traduzir-se num trabalho

\footnotetext{
${ }^{161}$ Este espaço designado por folhetim tornou-se um hábito de leitura fortemente implantado sobretudo no século XIX. Em Portugal, revelou-se um meio de sustento de muito escritores que ganharam visibilidade a partir da publicação das suas obras neste espaço, como refere Ana Teresa Peixinho "[...] O Mistério da Estrada de Sintra é, como tantas outras obras do século XIX, um romance que, antes de vir a lume numa edição em livro, foi publicado ao longo de dois meses em contexto jornalístico. Este tipo de publicação era muito comum na época e os próprios jornais organizavam a sua disposição gráfica em função da presença de textos literários de índole muito diversificada." (2010: 408).

${ }^{162}$ De acordo com Reis e Lopes, “(...) uma telenovela apresenta em princípio uma sintagmática narrativa consideravelmente dilatada, repartida em episódios de extensão regular (cerca de 45 minutos), totalizando quase sempre mais de uma centena de unidades, exibidas ao longo de vários meses."(2007: 402).

${ }^{163}$ Cristina Castilho Costa (2000) aponta o gancho como elemento fundamentalmente motivador e indispensável para as audiências, por desempenhar a tarefa de integração dos blocos entrecortados da narrativa tipicamente fragmentar da telenovela. A partir das disposições de Umberto Eco sobre o ritmo narrativo, a autora conclui que "o gancho sintetiza o já visto e prepara o por ver. Estabelece a ponte entre os segmentos, costura as pontas, alinha os conflitos e justapõe os opositores." (2000: 183), assim como "[...] elege aquilo que sintetiza a trama, o que deve ser remetido para a memória, aquilo que representa a solução dos problemas e a satisfação dos desejos." (2000: 186).
} 
de autoria coletiva ${ }^{164}$; o estigma de produto da indústria cultural precisamente devido a esta relação mercadológica de interferência da opinião dos consumidores na produção artística; e, por último, a sucessão de "intrigas recheadas de incidentes excitantes" (Reis, 1995), protagonizadas por personagens-tipo de inspiração estética advinda da literatura oitocentista mais estereotipada (Reis, 1995: 36). Na mesma linha de pensamento, João Paulo Moreira atribui a longevidade das narrativas seriadas a um pequeno conjunto de características estáveis e facilmente descodificáveis pelos leitores, que o autor sintetiza como:

\begin{abstract}
(...) sequencialidade narrativa; múltiplos fios de ação, habilmente entrelaçados; uma dosagem parcimoniosa, através de breves episódios diários; um elenco de personagens relativamente vasto, e desse modo multiplicador das possibilidades de identificação (Moreira, 2000: 6).
\end{abstract}

Para além das narrativas modernas como os romances-folhetim, Costa (2000) identifica, nas narrativas populares de tradição oral, outra matriz cultural da telenovela. As histórias repassadas de geração em geração foram compiladas e transpostas para a forma escrita pelos árabes, porém a origem de contos como As mil e uma noites aponta para regiões orientais como a índia e a antiga pérsia, segundo a autora. A permanência destes contos milenares, como fonte de inspiração

\footnotetext{
${ }^{164}$ Nessa discussão, Reis e Lopes apontam que "[...] a telenovela implica uma modificação do próprio estatuto da autoria, em relação, por exemplo, ao que ocorre com um género literário como o romance; se já neste caso o romancista dificilmente se alheia dos gostos e preferências do público, no caso da telenovela deve afirmar-se que são esses gostos e preferências que regem o desenvolvimento das histórias e os destinos das personagens; reelaboradas à medida que sondagens de opinião evidenciam as reações do público, as histórias que as telenovelas narram evoluem em sintonia com essas reações [...]" (2007: 402), na mesma linha de pensamento de Cristina Castilho Costa sobre o trabalho coletivo dos autores, que para além da equipa, "[...] têm acesso aos resultados das pesquisas que auferem o êxito da história e aos comentários dos group discussion [...]" (2000: 197).
} 
narrativa em contextos culturais diversamente contrastantes, pode indicar que certas características como o entrelaçamento de histórias e o processo de ritualização contribuem para a fidelização de leitores com identidades distintas, comprovando a dimensão universal tanto da narrativa (Costa, 2000), como, diríamos, da atração emocional pela narrativa. De maneira semelhante, ao sistematizar as características histórico-estruturais da telenovela, Moreira (2000) cotejou ambos os modos ficcionais e, apesar de considerar exagerada a associação do nascimento da narrativa seriada aos contos d'As Mil e Uma Noites - em virtude da décalage de mais de setecentos anos entre os manuscritos orientais e a publicação tardia no século XVIII da primeira tradução no contexto europeu - , o autor considera inegável o impacto da matriz metanarrativa advinda do oriente.

No mesmo sentido, o empenho na tarefa de delinear a evolução histórica da telenovela brasileira é notável no trabalho de outros autores, como Renato Ortiz (1989), para quem a reconstrução do passado da telenovela apresenta tanto continuidades, como ruturas. A partir deste movimento não-linear, antes de aclimatar-se à realidade mediática do país nos anos 1950, sustentada pelas raízes oitocentis$\operatorname{tas}^{165}$, a telenovela absorve características estruturais das produções norte-americanas e de outros países da América latina. Em Cuba, sobretudo em Havana, cidade onde o sistema radiofónico avançava em conjunto com os EUA na década de 1930, devido à proximidade de centros como Miami, despontam as primeiras experiências dramatúrgicas, fruto de uma ampla rede de radiodifusão que contava com recursos humanos qualificados ao nível técnico e artístico (Ortiz,

\footnotetext{
${ }^{165}$ Vale lembrar que a imprensa brasileira inicia a publicação das traduções dos folhetins iniciados em Paris, como Capitão Paulo de Alexandre Dumas, divulgado em 1838 no Rio de Janeiro pelo Jornal do Comércio, com uma diferença temporal de poucos meses relativamente à França (Ortiz, 1989:15). Apesar deste aspeto revelar um nível de desenvolvimento da imprensa no país, relativamente elevado para uma sociedade colonial, todavia, o romance-folhetim não consegue ultrapassar a dimensão elitista que acaba por caracterizá-lo no Brasil, devido ao baixo índice de escolaridade da população (Ortiz, 1989:17).
} 
1989: 23). No mesmo período, a necessidade de estimular o consumo após a Grande Depressão, que se abateu sobre os EUA no período pós-1929, resulta no investimento das fábricas de produtos de limpeza e higiene como a Colgate-Palmolive, Lever Brothers e Protect and Gamble, num espaço que se consolidava junto do público: os programas radiofónicos. Este investimento revela-se crucial para o desenvolvimento da ficção seriada na rádio, que denominar-se-á soap opera, como alusão aos sabões utilizados nas tarefas domésticas pelo público inicialmente maioritário destes programas, as donas-de-casa, e ópera, como referência ao género operático destes melodramas apoiados em temáticas que incidem sobretudo na esfera privada (Ortiz, 1989; Allen, 1995; Moreira, 2000; Cunha, 2011). Como aponta Robert Allen, "[...] within only a few years soap operas proved to be one of the most effective broadcasting advertising vehicles ever devised" (1995: 2), contribuindo, fundamentalmente, para o desenvolvimento dos sistemas de radiodifusão, tanto nos EUA, como noutros países.

Apesar da desconfiança inicial ${ }^{166}$, a televisão tornar-se-ia, a posteriori, uma plataforma de distribuição eficaz para as soaps, definidas estruturalmente pela serialidade, em conjunto com uma estratégia de emissão fixa e diurna para um público predominantemente feminino e adulto (Cunha, 2011: 44). Este ícone da televisão anglo-saxónica diferencia-se fundamentalmente da produção latino-americana pela dimensão estrutural. Tanto na rádio, como na TV, enquanto nos EUA as narrativas se estendem durante anos de forma repartida, geralmente em episódios unitários de trinta a sessenta minutos com começo, meio e fim, nos países latino-americanos, como México e Cuba (e, posteriormente, o Brasil), as histórias desdobram-se por um período de aproximadamente um ano, de maneira igualmente seriada, porém com capítulos diários que serão interrompidos nos

\footnotetext{
${ }^{166}$ Os anunciantes tiveram receio que os afazeres domésticos atrapalhassem a receção feminina das soap operas num meio que, a priori, exigiria total atenção ao conteúdo imagético (Costa, 2000; Cunha, 2011).
} 
momentos de tensão - estratégia denominada no Brasil como gancho. Centradas geralmente nos conflitos familiares e românticos, as temáticas repetem-se. Contudo, a adoção de diferentes estilos impossibilita a identificação de uma unidade na produção televisiva seriada, destacando-se o pendor dos títulos latino-americanos para o melodrama ${ }^{167}$ (Cunha, 2011: 54).

O início da trajetória da telenovela brasileira - matriz da ficção televisiva portuguesa - caracteriza-se por esta miscelânea de tendências estrangeiras, sobejamente influenciada pelo modelo cubano, sobretudo na componente estrutural. No plano dos conteúdos, a adaptação de textos consagrados da literatura internacional, em conjunto com a inspiração derivada do cinema, associam componentes fundamentais para a alteração frequente dos eixos dramáticos inicialmente orientados pelo modelo do melodrama latino-americano. O período de (in) definição identitária inicia-se com a primeira telenovela, em $1951^{168}$, apresentada apenas duas vezes por semana, e perdura durante os anos seguintes, que registam também influências doutros campos artísticos para além da rádio, tais como o teatro e o teleteatro (Ortiz, 1989). Entre os profissionais destes meios, reside uma divergência de princípios, pois os atores e produtores do campo teatral desprezavam inicialmente a telenovela por considerá-la inferior, o que resultaria posteriormente na elevação do nível das produções da TV. Destas raízes artístico-culturais que contrastavam com a lógica industrial e económica inerente aos programas televisivos, a telenovela brasileira herda uma componente crítica responsável pelo questionamento da estruturação maniqueísta que caracteriza o dramalhão

\footnotetext{
${ }^{167}$ Como pontua Costa: "Quase todos os conflitos são ameaças à ordem social vigente: filhos ilegítimos, orfandade, incestos, adultérios. As personagens envolvidas dividem-se claramente em heróis e vilões, oponentes durante toda a história, terminando necessariamente num happy end que premeia os bons, castiga os maus, realiza o amor romântico e reafirma as regras e os valores sociais" (2000: 149).

${ }^{168}$ De acordo com Renato Ortiz, A sua vida me pertence, de autoria de Walter Foster, estreou na extinta TV Tupi de São Paulo em 1951.
} 
latino-americano. Com o alargamento do sistema televisivo, entre as décadas de 1950 e 1970, surgem novas emissoras, como a Excelsior, responsável por emitir a primeira telenovela diária, em 1963: 2-5499 ocupado (Ramos e Borelli, 1989:84). Durante a década de 1950, a Rede Globo, do grupo Roberto Marinho, conquista a concessão de um canal e inicia a expansão do seu império audiovisual com auxílio do capital norte-americano do grupo Time-Life em 1962 (Sousa, 1998). A partir da década de 1970 , no início da modernização do panorama mediático, ainda sob um regime estatal autoritário, a Globo alinha a sua produção tanto pelas transformações socioeconómicas do país, como pelos ditames estatais que previam a afirmação de uma cultura nacional (Ramos e Borelli, 1989:84). A partir daí, nota-se um abrasileiramento da produção, fundado numa proposta estética mais realista, o qual se inicia, segundo Immacolata Lopes, a partir da telenovela Beto Rockfeller (TV Tupi), em 1968.

\section{A ficção televisiva no contexto português}

Quando as primeiras telenovelas portuguesas iniciaram a sua trajetória na televisão nacional, o país estava habituado às ficções brasileiras que se encontravam em plena fase de internacionalização desde a década anterior (Costa, 2003). Neste sentido, a partir do final dos anos 1970, a Rede Globo exportou os primeiros títulos de ficção emitidos em Portugal, quando a produção nacional ainda era inexistente e o mercado estava aberto para os produtos ficcionais dos países mais próximos em termos de língua e cultura (Cádima, 1995; Traquina, 1997; Sousa, 1998; Teves, 2007). De maneira paradigmática, Gabriela ${ }^{169}$ (Rede Globo) inaugura o género em 1977 e

\footnotetext{
${ }^{169}$ Conforme mencionamos no final deste capítulo, o estudo de Cunha (2011) comprovou a importância de Gabriela para a sociedade portuguesa da época.
} 
consegue parar o país em frente à TV, para além de permanecer notadamente viva no imaginário popular dos portugueses, durante mais de três décadas. Apesar da tradição folhetinesca da radionovela (Moreira, 2000), Gabriela tornar-se-ia responsável pela introdução e consequente proliferação das telenovelas em Portugal (Costa, 2003). Com o nascimento desta paixão, confirma-se a entrada triunfal da ficção na TV e a abertura do mercado aos títulos brasileiros, que dominaram o panorama audiovisual até o final dos anos 1990, quando as sucessivas diretrizes legislativas ${ }^{170}$ iniciam um processo $^{171}$ que culmina no afastamento dos programas estrangeiros do horário nobre da televisão (Costa, 2003; Cunha, 2011).

O passado da produção nacional de ficção é marcado pela estreia da primeira telenovela portuguesa - Vila Faia (RTP1), em 1982 ${ }^{172}$, dois anos após o início da emissão televisiva a cores. Apenas cinco telenovelas foram produzidas no país ${ }^{173}$ durante os anos 1980, enquanto a soberania das produções brasileiras se confirmava pelas audiências e títulos ${ }^{174}$ emitidos neste período de paleotelevisão (Casetti e Odin, 1990), caracterizado pelo monopólio estatal da TV. Coincide com este período a primeira fase de democratização do país que saíra dum regime ditatorial há apenas três anos e apresentava

\footnotetext{
170 Entre elas, a Lei da Televisão (31-A/98 de 14 de julho) e a Diretiva 2001/29/CE.

${ }^{171}$ De acordo com Cunha, "no final da década de noventa surgem duas organizações, Comissão Inter-Ministerial para o Audiovisual (1997) e a Plataforma do Audiovisual, com o objetivo de propor linhas de ação e fomentar a produção de conteúdos em português. (...) Estas iniciativas resultaram num aumento significativo de oferta de ficção portuguesa em todos os canais generalistas, não só em horas/emissão como na oferta e variedade de géneros (adaptados a Portugal ou criações), nomeadamente telenovelas, séries e telefilmes." (2011: 30).

172 "Assinavam-no um ator de revista e cómico (Nicolau Breyner) e um produtor televisivo (Thilo Krassman). A realização era de Nuno Teixeira, um realizador da RTP, e a produtora era a Edipim." (Albuquerque e Vieira, 1995)

${ }^{173}$ Vila Faia (1982), Origens (1983), Chuva na areia (1985), Palavras cruzadas (1987) e Passerelle (1988) (Costa, 2003; Cunha, 2010).

${ }^{174}$ Entre 1981 e 1989, foram emitidos seguintes títulos do Brasil: Água Viva (1981), Olhai os Lírios do Campo (1981), Baila Comigo (1982), Cabocla (1982), Pai Herói (1983), O Bem Amado (1984), Louco Amor (1985), Vereda Tropical (1986), Viver a Vida (1986), Roque Santeiro (1987) e Sinhá Moça (1989), (Costa, 2003).
} 
os primeiros sinais de estabilização política, o que colaborou para o espírito de confiança do grupo pioneiro de produtores ${ }^{175}$ (Costa, 2003; Cunha, 2011). Nos primeiros ensaios portugueses num terreno antes desconhecido, apesar de tentar reproduzir o modelo brasileiro, o atraso produtivo de mais de vinte anos resulta num produto nacional de qualidade analogamente inferior à concorrência (Albuquerque e Vieira, 1995; Costa, 2003).

\begin{abstract}
(...) faltava experiência aos muitos agentes envolvidos: os escritores estavam habituados à linguagem teatral ou de revista; os atores moviam-se na televisão como se estivessem no palco e não conseguiam ignorar as câmaras; não havia técnicos de som e iluminação, a cenografia deixava muito a desejar (Cunha, 2011: 94).
\end{abstract}

Para além disso, a pobreza do texto (Alburquerque e Vieira, 1995) e a sonoplastia contribuem para uma certa recusa inicial das audiências. Nem a reunião de elementos e temáticas próprios da sociedade portuguesa conseguiram cativar o público, de maneira que o êxito desta portugalidade só despontaria quase vinte anos depois (Cunha, 2011: 94). Quer isso dizer que, mesmo após a entrada dos operadores privados e consequente abertura à concorrência, no início da década de 1990, as estratégias continuaram voltadas para as telenovelas brasileiras, por mais dez anos. O êxito das teleficções portuguesas só desponta com a compra da TVI pela Media Capital, em 1999, quando a emissora implementa uma nova estratégia centrada na criação de celebridades nacionais que se ancoram nas telenovelas e no primeiro reality show, resultando eficazmente na sustentação de um star system português (Cunha, 2011). É durante a primeira década do século XXI

\footnotetext{
${ }^{175}$ Nesse âmbito, Jorge Paixão da Costa destaca a produtora Edipim em conjunto com os seguintes nomes: Nicolau Breyner, Francisco Nicholson, Nuno Teixeira e Thilo Krassman (2003:108).
} 
que a ficção televisiva portuguesa atinge o seu auge em termos de número de títulos produzidos e êxito de audiências, ancorado, por um lado, nessas estratégias de produção integrada de conteúdos, e, por outro lado, em termos legislativos, no protecionismo dos conteúdos nacionais emitidos durante o prime-time.

\section{As narrativas televisivas no digital}

Diante das alterações da nova ecologia mediática, caracterizada pelos avanços das tecnologias da informação e da comunicação, crescem os desafios da indústria televisiva, sobretudo no tocante à multiplicação dos ecrãs, digitalização dos conteúdos e fragmentação das audiências (Butler, 2006; Ford et al., 2011; Jost, 2011). Mudanças que reclamam uma nova identidade da TV, fundamentada em novas práticas interacionais e produtivas que desafiam a lógica de programação linear e em fluxo, tensionando os seus modelos de negócio (Ross, 2008; Jenkins, 2009; Doyle, 2010; Fechine et al., 2013). Os conteúdos, como a ficção, obedecem essa nova lógica cultural e económica, de estreitamento da relação entre público e TV por meio de diferentes formas de interatividade e participação, para além da liberdade de escolha oferecida pela TV por demanda. Todas essas transformações, em conjunto com as plataformas de livre acesso e partilha de conteúdos disponíveis no online, solicitam uma dupla abordagem desses campos para análise das novas formas de acesso e relacionamento com a ficção produzida pelas emissoras de TV de sinal aberto. Assim, o notável impacto das TIC revela-se na adoção de novas estratégias de produção e distribuição destes conteúdos, pois atualmente quase todos os programas de ficção televisiva experimentam o online, produzindo variados tipos de brand extensions, atraindo os leitores para estes paratextos infinitos (Lacalle, 2010: 98). 
Assim, numa cultura dos media convergentes (Jenkins, 2009), a incerteza sobre o futuro da televisão é dos principais assuntos discutidos atualmente na academia, inclusive em Portugal (Cádima, 1999; Damásio, 2004; Buonanno, 2008; Butler, 2006; Jost, 2011). Será o fim da TV ou uma revolução drástica dos modos de produção e receção televisiva? Durante os anos 1990, as previsões sobre o impacto das TIC no consumo dos media previam, antecipadamente, a oposição da filosofia das redes de computadores - que operam tanto enquanto fonte, como destino - e das redes de televisão que pressupõem uma hierarquia de distribuição (Negroponte, 1995: 191). Por isso, o caminho para uma "evolução" da TV conjeturava a aliança destas duas filosofias, deslocando a inteligência do emissor para o recetor (1995: 27).

As reflexões sobre o futuro da TV neste período, em Portugal, apontavam para o desdobramento multisuporte dos conteúdos televisivos, representando uma alteração dos fluxos para um sistema de estoque e webcasting (Cádima, 1999: 102). Neste sentido, imaginava-se a extinção do espartilho da grelha televisiva e oferta dos programas em função do perfil do assinante, disponíveis numa diversificada gama de suportes (1999: 102).

À medida que as revoluções se intensificam, arriscar um palpite sobre os novos rumos da TV é, cada vez mais, considerada uma missão espinhosa. A maioria dos intelectuais permanece numa zona de conforto ao pontuar as alterações observadas nestes tempos de indefinição. "O que será da televisão em 10 anos? Terá ainda canais ou todos os conteúdos passarão pela internet?" (Jost, 2011: 107). Mesmo admitindo a dificuldade de responder estas questões, François Jost aponta, de imediato, duas certezas:

A primeira é que o combate pela convergência será duro; o fim do combate, incerto, e que não é fácil saber quem ganhará: a tela da televisão ligada à internet ou a tela do 
computador utilizada como televisão. Não é menos difícil prever o lugar que terá a TMP (a televisão móvel pessoal) nas nossas vidas. A segunda certeza é que as possibilidades da seleção pessoal e de individuação dos conteúdos vão se multiplicar (Jost, 2011: 107).

Sobre a primeira afirmação de Jost, é líquido que, de forma mais ou menos conflituosa, convivem estas duas hipóteses: tanto a aproximação da TV à interatividade possibilitada pelas técnicas digitais, como a tela do computador adotada como televisão. Assim, a chegada doutros aparelhos permite o acesso aos programas a partir de plataformas como o YouTube, promovendo formas de receção e consumo dos programas mais interativas e participativas (Jenkins, 2009). No mesmo sentido, Jeremy Butler aponta o aumento da interatividade e do poder de decisão das audiências, além da possível produção de conteúdos pelos públicos, como principais resultados da postnetwork television (2006:12).

No entanto, ao observar plataformas de difusão de conteúdos audiovisuais, tais como o YouTube, como espaços culturais de participação, é importante considerar que sites de partilha de vídeos online podem não ser completamente opostos ao sistema de televisão broadcast. Isso porque podem significar formas diferentes de institucionalização da televisão, onde o poder das indústrias mediáticas ainda consegue modelar as formas de participação (Müller, 2009: 59). De acordo com Eggo Müller, a romântica metáfora de Jenkins sobre a convergência dos meios, independente de qualquer mecanismo de distribuição específico, representando uma mudança de paradigma assente em relações mais complexas entre os media corporativos, de cima para baixo (top-down), e a cultura participativa, de baixo para cima (bottom-up), em certa medida, deve ser considerada como uma perspetiva utópica, devido à estruturação institucional e cultural da TV interativa e dos sites de partilha de vídeos (Müller, 2009: 59). Como podemos observar, cada 
teórico refere, nestas abordagens, a sua ideia sobre o futuro da TV, de forma mais ou menos arrojada. No entanto, apesar da preocupação com as mudanças nas formas de produção e consumo, poucos acreditam no fim apocalíptico da televisão.

Como resultado destas alterações, assentes na migração do eletrónico para o digital (Vilches, 2003), notámos o surgimento de confusões terminológicas, tanto na academia, como no senso comum. Tal como refere Scolari, os públicos continuam a nomear a atividade de acompanhar as narrativas em diferentes plataformas com o verbo "ver" ou "assistir":

As pessoas dizem, por exemplo, "eu vejo Lost" ou "eu vejo Big Brother", mas esse "ver" é, em muitos casos, radicalmente diferente do velho "ver" televisivo. Hoje, "ver Lost" ou "ver Big Brother" inclui práticas como navegar na web, fazer download de capítulos de forma ilegal, consumir vídeos no YouTube ou discutir sobre o programa em uma rede social ou fórum. O peso da experiência televisiva é muito forte, por esse motivo ainda se continua a falar de ver. (Scolari, 2011: 128-129)

Em termos de ficção, em decorrência destas transformações no consumo televisivo, observa-se a preocupação dos intelectuais em apontar características e fixar uma designação adequada das novas narrativas produzidas pelas indústrias da cultura. Com os dispositivos tecnológicos disponíveis no mercado, acompanhar uma história no século XXI significa vivenciar uma experiência de envolvimento mais profundo com o drama (Evans, 2011). Por isso, a proposta deste capítulo é destacar as abordagens teóricas que indicam os caminhos desta nova ficção, denominada por diversos autores como narrativa transmedia, em inglês, transmedia storytelling (Jenkins, 2010; Giovagnoli, 2011; Pratten, 2011; Evans, 2011; Scolari, 2013). 


\title{
Textos transmedia - novo passeio pelos bosques da ficção ${ }^{176}$
}

Em linhas gerais, Jenkins ${ }^{177}$ define como narrativas transmedia o relato das histórias distribuído em diversas plataformas mediáticas, com cada texto a contribuir de forma distinta e importante para o todo (2009:138). Na era da convergência, o sucesso deste entretenimento ${ }^{178}$ depende da vasta integração de múltiplos textos, onde uma narrativa é concebida de forma sinergicamente ampla, capaz de extrapolar os limites iniciais de um único meio e migrar para outras plataformas.

\begin{abstract}
A transmedia story represents the integration of entertainment experiences across a range of different media platforms. A story like Heroes or Lost might spread from television into comics, the web, computer or alternate reality games, toys and other commodities, and so forth, picking up new consumers as it goes and allowing the most dedicated fans to drill deeper. The fans, in turn, may translate their interests in the franchise into concordances and wikipedia entries, fan fiction, vids, fan films, cosplay, game mods, and a range of other participatory practices that further extend the story world in new directions. Both the commercial and grassroots expansion of narrative universes contribute to a new mode of storytelling, one which is based on an encyclopedic expanse of information which gets put together differently by each individual consumer as well as processed collectively by social networks and online knowledge communities. (Jenkins, 2010: 448).
\end{abstract}

\footnotetext{
${ }^{176}$ Frase alusiva ao livro de Umberto Eco "Seis passeios pelos bosques da ficção" (1997).

${ }^{177}$ Autor considerado o precursor do conceito de transmedia storytelling (Scolari, 2011).

178 Um exemplo deste novo entretenimento é o universo Matrix, uma trilogia cinematográfica que se desdobra em três filmes, desenhos animados, banda desenhada e videojogos. Matrix é o principal exemplo apontado por Jenkins como narrativa transmedia.
} 
Em resumo, diferentes meios estão envolvidos neste mundo ficcional (Murray, 1997), constituído por uma linha temporal longa, com personagens mais complexas a cada plataforma explorada e relatos diferentes entre si, apesar de emergirem de uma mesma narrativa (Fechine e Figueirôa, 2009), originando um entretenimento penetrante (Pratten, 2011) ou deeper (Rose, 2011). Assim, para além da expansão do universo ficcional de forma enciclopédica (Eco, 1994; Murray, 1997), os consumidores mais atentos aos programas, como os fãs, protagonizam este processo em conjunto com as indústrias produtivas, indicando as suas preferências, "caçando informações" e até modificando as histórias, de forma ativa, participativa e coletiva (Jenkins, 2009:185).

A emergência desse novo campo de estudos fomenta o labirinto terminológico e conceptual, originando significados pacificamente complementares ou criticamente antagónicos. Em relação ao conceito de transmedia storytelling, Jenkins (2010: 944) indica outras formas de definição da mesma ideia como deep media (Rose, 2011) e crossmedia $^{179}$ (Dena, 2009; Davidson et al., 2010), assim como Elizabeth Evans aponta a existência de abordagens muito semelhantes sobre o mesmo fenómeno (2011: 19).

$\mathrm{Na}$ mesma linha de pensamento, Scolari (2013) identifica o crescimento de uma galáxia semântica em torno do conceito de transmedia storytelling - um planeta dentro de uma imensa galáxia conceitual, formada por termos que procuram nomear uma só experiência: a prática de produção de sentido e interpretação, baseada em histórias que se expressam através da combinação de linguagens, meios e

\footnotetext{
${ }^{179}$ Ao definir o termo, os autores explicam como opera a comunicação crossmedia: "Cross-media refers to integrated experiences across multiple media, including the Internet, video and film, broadcast and cable TV, mobile devices, DVD, print, and radio. The new media aspect of the "cross-media experience" typically involves some high level of audience interactivity. In other words, it's an experience (often a story of sorts) that we "read" by watching movies, dipping into a novel, playing a game, riding a ride, etc." (Davidson et al., 2010: 23).
} 
plataformas (Scolari, 2003: 26). Em concordância, Giovagnoli (2011) indica que a história de definição do conceito ainda permanece em construção e cabe aos académicos e companhias produtoras escrevê-la com propriedade. Assim como Scolari, este autor traça um estado da arte esclarecedor sobre o assunto, clarificando a origem e o uso deste termo por amadores e profissionais. O trabalho de Giovagnoli foi reconhecido por Jenkins como uma das obras mais académicas da área ${ }^{180}$, em contraste com os diversos manuais ${ }^{181}$, publicados nos últimos anos, para os potenciais criadores transmedia.

Giovagnoli (2011: 23) descreve a genealogia do conceito, apontando o trabalho da investigadora americana Marsha Kinder Playing with Power in Movies, Television, and Video Games: From Muppet Babies to Teenage Mutant Ninja Turtles, livro lançado em 1991, como precursor, no ocidente, do termo transmedia, onde ela refere projetos comerciais em múltiplos meios que formam supersistemas transmedia das marcas globalmente distribuídas. Do lado da produção, o CEO da Time inc. Paul Zazzera, menciona, em 1996, o conhecido termo crossmedia, refinado posteriormente pelos investigadores Christy Dena e Jak Bouman, para designar os projetos desta linha (Giovagnoli, 2011: 24). Mais tarde, em 2003, Jenkins publica na revista do MIT um artigo ${ }^{182}$, elucidando as características destas experiências, difundidas globalmente, de forma inesperada e aleatória (Giovagnoli, 2011: 24). Por último, a indústria cinematográfica americana adere ao termo, acrescentando nos créditos finais dos filmes produzidos

\footnotetext{
${ }^{180}$ Jenkins refere-se ao livro Transmedia Storytelling: Imagery, Shapes and Techniques (Giovagnoli, 2011).

${ }^{181}$ Entre os manuais para produtores transmedia lançados nos últimos anos temos: Getting started with storytelling (Pratten, 2011); The Producer's Guide to Transmedia: How to Develop, Fund, Produce and Distribute Compelling Stories Across Multiple Platforms (Bernardo, 2011); A Creator's Guide to Transmedia Storytelling: How to Captivate and Engage Audiences Across Multiple Platforms (Phillips, 2012).

${ }^{182}$ Jenkins, H. (2003). "Transmedia storytelling. Moving characters from books to films to video games can make them stronger and more compelling". Technology Review. [Disponível em] http://www.technologyreview.com/news/401760/transmedia-storytelling/
} 
em Hollywood a função do produtor transmedia, conforme descreve o guia de orientação de Jeff Gomez (Giovagnoli, 2011: 25).

De acordo com Evans (2011), é importante pontuar as diferenças entre as narrativas transmedia e as produções tradicionais de ficção, tendo vista que a materialização das narrativas sempre ocorreu em plataformas diferentes (2011: 19). Ao definir este conceito, Jonathan Gray (2010: 23), classifica os elementos de expansão do universo ficcional (promoções, spoilers e spin-offs) utilizando a expressão de Gérard Genette ${ }^{183}$ : paratextos. Assim, se as narrativas podem concretizar-se em diversos suportes expressivos - verbais, icónicos ou verbo-icónicos (Reis e Lopes, 2007: 271), o fenómeno da narrativa transmedia não seria inteiramente novo, apesar das suas qualidades experimentais e inovadoras (Jenkins, 2009: 172).

Conforme indica o produtor Nuno Bernardo, fundador da beActive ${ }^{184}$, por baixo do guarda-chuva transmedia encontramos diferentes técnicas e abordagens, tais como: a extensão da marca (modelo fortemente implementado pelas empresas de TV, como websites e aplicativos para telemóvel - extensões do produto principal); produção para web (webisodes e mobisodes - conteúdos exclusivamente produzidos para dispositivos móveis); mundos transmedia (comum nas empresas Hollywood para criar um mundo a partir ficção) e transmedia orgânico (projetos menores originalmente pensados para um número limitado de plataformas).

\footnotetext{
${ }^{183}$ De acordo com a definição de Gerárd Genette "(...) the paratext is what enables a text to become a book and to be offered as such to its readers and, more generally, to the public." (2001:1). Por outras palavras, o paratexto é um prolongamento da obra original que depende das formas de mediação, pois, antes de serem publicados como livro, os textos não possuem elementos paratextuais como título, subtítulos, intertítulos, prefácios, preâmbulos, apresentação e outras informações adicionais que influenciam o consumo dos leitores.

${ }^{184} \mathrm{Em}$ termos de produção de conteúdos de ficção transmedia, a beActive é uma referência em Portugal.
} 
(...) transmedia storytelling involves creating content that engages the audience using various techniques to permeate their daily lives. In order to achieve this engagement, a Transmedia production will develop storytelling across multiple forms of media in order to have different entry points into de story. These entry points are the places where the audience can access content, with each point also providing their own unique perspective on the overall story (Bernardo, 2011: 3).

No intuito de sugerir como planear uma experiência transmedia satisfatória, que entusiasme os consumidores e os induza a colaborar com a expansão do relato (Scolari, 2013: 114), Robert Pratten (2011) descreve em seu manual as principais diferenças entre as franquias ${ }^{185}$ tradicionais e as transmedia. O modelo de negócio proposto por Pratten (2011: 84) assenta na produção inicial de conteúdos de baixo orçamento (low-cost), com o objetivo de angariar audiências e fundos para execução do projeto completo. Em termos de conteúdos, para conseguir atingir os resultados esperados, a ideia é escrever histórias com diversas camadas e sub-plots - enredos paralelos - destinados especificamente aos dispositivos móveis para fruição em tempo real ou por demanda (2011: 84).

Neste sentido, Pratten indica dois caminhos opostos para iniciar um projeto transmedia: a elaboração prévia da narrativa ${ }^{186} \mathrm{e}$, a seguir, da experiência ${ }^{187}$ ou vice-e-versa. Por razões económicas, tanto Pratten, como Bernardo, preferem começar o projeto imaginando a experiência transmedia em primeiro lugar, pois uma narrativa ambientada noutro país, por exemplo, exige um esforço muito maior de produção que

\footnotetext{
${ }^{185}$ Os produtores usam o termo franquia para indicar a marca (e.g. Diário de Sofia) que vai gerar produtos distintos.

${ }^{186}$ Escolha do género, enredo, personagens, localização geográfica e etc.

${ }^{187}$ Cronograma, plataformas, localização e agency (nível de controle das audiências).
} 
deve ser inicialmente previsto. Assim, estes produtores assumem que as narrativas ficam subordinadas ao suporte de materialização. É importante referir, ainda, que cada empresa procura aperfeiçoar o modelo anterior, como esclarece o criador de Diário de Sofia:

Ao modelo de Robert Pratten eu adiciono um overlap, ou seja, não repetir o conteúdo, mas adicionar elementos que fazem overlap, porque na peça de puzzle perfeita não há overlap de conteúdos e isso também é desinteressante. O que cria algo mais rico para a experiência são os elementos de um formato que aparecem no outro (Bernardo, 2014).

Do ponto de vista teórico, após refletir sobre este fenómeno e realizar um estudo de receção no Reino Unido, com o público de duas séries ${ }^{188}$, Evans concluiu que a principal diferença entre os antigos fluxos ficcionais - como os romances literários adaptados para o cinema ou TV - e os transmediáticos, seria a expansão das histórias para outros formatos conforme três preceitos: combinação narrativa, autoria e coerência temporal (Evans, 2011: 38).

Em termos de combinação narrativa, a forma ideal de transmediação pressupõe alteração ligeira do conteúdo e interligação entre os meios, onde cada plataforma oferece oportunidades diferentes de fruição da história (Jenkins, 2009:139). Por outras palavras, o universo narrativo é explorado de acordo com as potencialidades de cada meio, evitando a redundância e oferecendo novos níveis de revelação e experiência, pois a repetição aborrece os leitores (2009: 138). Por seu turno, Dena (2009: 55) defende que o emprego de distintos media modificam por si os processos de construção de significados da mesma história, sem necessitar de remodelação a priori dos conteúdos, pois os usos dos meios implicam a compreensão dos

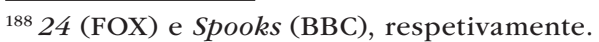


affordances $^{189}$ do mesmo - um videojogo oferece formas de interação diferentes do livro ou do filme.

Ao contrário de algumas adaptações ${ }^{190}$ e outras formas de intertextualidade ${ }^{191}$, a autoria dos conteúdos transmedia, normalmente, concentra-se na figura da empresa produtora dos conteúdos, como no caso da beActive em Portugal. Nuno Bernardo $(2011 ; 2014)$ refere em seu manual ${ }^{192}$ para produtores transmedia que a estratégia de marketing brand extension - lançamento de diferentes produtos com a mesma marca - é uma das características da produção transmedia. No mesmo sentido, Jenkins aponta esta unidade de criação e controle dos conteúdos como elementos importantes para o êxito das franquias transmedia (2009:150).

Sobre a questão da temporalidade, o lançamento dos produtos transmedia deve ocorrer em períodos previamente combinados, nas várias plataformas envolvidas, diferindo das adaptações existentes no mercado, lançadas, por vezes, após meses ou anos da difusão do produto "original" (Evans, 2011: 36). Jeff Gomez ${ }^{193}$ corrobora esta ideia, esclarecendo que na produção transmedia nativa os projetos são desenhados desde o início para operar em várias plataformas

\footnotetext{
${ }^{189}$ A autora emprega este termo para indicar as características de cada meio de comunicação.

${ }^{190}$ Adaptação - tradução intersemiótica de um mesmo relato de um sistema de significação a outro - ou transmutação, no contexto audiovisual, é a transformação do signo arbitrário constituído pela palavra (escrita) em signo icónico, processo próprio destes meios, tanto do cinema, como da televisão (Balogh e Mungioli, 2009: 317).

${ }^{191}$ De acordo com Costa, a intertextualidade - interpenetração de signos e mensagens de outros meios na narrativa original - é um elemento próprio das ficções produzidas para a televisão: "[...] a telenovela acaba se transformando numa teia intertextual de formas expressivas que se reforçam continuamente intercambiando influências (Costa, 2000: 167).

${ }^{192}$ Neste manual, Bernardo refere também a necessidade de gestão adequada da propriedade dos produtos para evitar certas armadilhas, tais como a apropriação indevida de ideias e aconselha, em caso de licenciamento da marca, a contratação de um agente para negociar estes acordos (2011: 131).

${ }^{193}$ Presidente e CEO da empresa americana de conteúdos transmedia Starlight Runner Entertainment.
} 
mediáticas de maneiras diferentes, assim como aconselha a bíblia ${ }^{194}$ de Bernardo (2011: 24) sobre o transmedia orgânico e a necessidade de definir previamente um cronograma para a história.

Em resumo, as três características apontadas por Evans colaboram para o entendimento do que define a narrativa transmedia, embora a nossa perspetiva não consiga ignorar a tensão entre produtores e consumidores como uma quarta diferença entre os antigos fluxos narrativos e a atual abordagem transmedia. Neste sentido, a introdução da internet como mediação contribui para desestruturação dos limites entre texto e leitor, resultando em profundas alterações nos processos de produção e receção de conteúdos de ficção (Booth, 2010).

O estilo de vida imersivo dos fãs, demonstrado no estudo de receção de Evans, revelou que estas audiências experienciam as narrativas imaginando uma terra prometida (2011: 91), no mesmo sentido que Janet Murray (1997) refere a ficção no digital como um lugar encantado, e, também, Sam Ford concebe as soaps como immersive story world (Ford et al., 2011: 240). Segundo este autor, a imersão na narrativa pode resultar em práticas simbólicas como recontar os momentos da vida das personagens (2011: 240). De maneira geral, se por um lado, os fãs exercem a inteligência coletiva influenciados pelo potencial imersivo do transmedia (Kosnik, 2011), por outro, valem-se destes apelos da indústria mediática como ferramenta de resistência, expondo as críticas sobre os programas favoritos (Hills, 2011).

Ao relatar a sua experiência nas indústrias televisiva e cinematográfica americana, Frank Rose afirma que o controle das ficções está crescentemente subordinado à opinião das audiências nos media sociais, originando uma verdadeira crise de autoria: "The author starts the story; the audience complete it. The author creates the characters and the situation they find themselves in; the audiences

\footnotetext{
${ }^{194}$ Vários autores referem a chamada "bíblia transmedia", que define a estrutura do projeto, orientando a produção transmedia (Bernardo, 2011; Scolari, 2013; Antunes, 2014).
} 
responds and makes it their own." (Rose, 2011: 88). O autor destaca as relações estabelecidas entre os fãs e os perfis das personagens no Twitter, citando como exemplo a série Mad Men. Segundo Rose, os produtores já não conseguem prever os resultados da interação das audiências com as personagens favoritas, sobretudo devido aos perfis e histórias criados pelos próprios fãs (2011: 93).

\section{Conclusão}

Diante das reconfigurações das formas de consumo televisivo, a preocupação com o futuro deste meio destaca-se como problemática central dos estudos que privilegiam a análise do universo audiovisual. Tanto teóricos, como produtores, esforçam-se para prever se esta revolução drástica dos modos de produção e receção televisiva vai desembocar num final trágico para o meio. Com auxílio do pensamento dos autores que refletiram acerca das narrativas ficcionais, sobretudo no que toca o suporte televisivo, concluímos que a análise destas alterações deve compreender ambas dimensões - produção e receção - dado que encontra-se nesta relação a chave para o entendimento de tal problemática. A partir desta certeza, verificámos que a lógica produtiva dos conteúdos ficcionais iniciou um percurso integrado de construção de novos mundos possíveis para os exigentes consumidores do século XXI. Este caminho é marcado pelo surgimento do conceito de narrativas transmedia, do inglês, transmedia storytelling, que assenta na produção duma experiência ficcional mais alargada que extrapola os limites da televisão.

Apesar do modelo encontrar-se em permanente discussão, percebemos, claramente, neste debate, que nem todas as narrativas que migram para multiplataformas podem ser classificadas como histórias transmedia. Por outras palavras, uma interpretação mais hermética do transmedia aplicado ao storytelling aponta para a construção de 
mundos possíveis, materializados em diversos suportes expressivos, onde cada texto contribui de forma distinta para o desenvolvimento da mesma história. Este novo padrão difere das antigas extensões narrativas, sobretudo porque integra um conjunto de regras definidas previamente pelas indústrias produtivas. Entre estas determinações, podemos destacar: a criação de uma bíblia transmedia - manual de orientação utilizado pelos produtores - que define a composição narrativa; a concentração da autoria produtiva; a organização temporal dos lançamentos em diferentes plataformas; o uso acentuado de espaços interativos, tais como as redes sociais na internet; e o incentivo ao envolvimento e participação ativa das audiências. Em resumo, os prolongamentos da obra original são estratégias previamente arquitetadas pelos autores e, em grande medida, podem sofrer influência das ações dos fãs.

\section{REFERÊNCIAS BIBLIOGRÁFICAS}

AlbuQuerque, D. E VIEIRA, A. (1995). "As Telenovelas em Portugal - história e teoria do género", in O Fenómeno Televisivo. Lisboa: Círculo de Leitores.

ALLEN, R. C. (Ed.). (1995). To be continued: soap operas around the world. Nova Iorque: Routledge.

ANACOM (2012), Lei da televisão, Lei n. ${ }^{\circ}$ 27/2007, de 30 de Julho. [online]. [Acedido em 27/05/2013]. Disponível em: http://www.anacom.pt/render.jsp?Contentid=958757 BACCEGA, M. A. (2012). "Ressignificação e atualização das categorias de análise da "ficção impressa" como um dos caminhos de estudo da narrativa teleficcional", in Comunicación. Sevilha, 1(10), pp. 1290-1308.

BACCEGA, M. A., CUNHA, I. F.; TONDATO, M.; MACEDO, D. e SANTANA, C. (2009). Gêneros televisivos e publicidade no prime-time português e brasileiro: a recepção como suporte das relações entre comunicação e práticas de consumo. Anuário internacional de comunicação lusófona 2009: memória social e dinâmicas identitárias. 
BERNARDO, N. (2011). The Producer's Guide to Transmedia: How to Develop, Fund, Produce and Distribute Compelling Stories Across Multiple Platforms. Beactive books.

BORELLI, S. (2001). “Telenovelas brasileiras: balanços e perspectivas”, in São Paulo em Perspectiva, 15 (3), pp. 29-36.

BOOTH, P. (2010). Digital fandom. Nova Iorque: Peter Lang Publishing.

BUONNANO, M. (2005). "La masa y el relleno. La miniserie en la ficción italiana", in Designis, Publicación de la Federación Latinoamericana de Semiótica (FELS), 7, pp. 19-30.

BUONNANO, M. (2008). The age of television: experiences and theories. Bristol: Intellect books.

BUTLER, J. G. (2006). Television: Critical methods and applications. Taylor \& Francis e-Library.

CÁDIMA, F. R. (1995). O Fenómeno Televisivo. Lisboa: Círculo dos leitores.

CÁDIMA, F. R. (1999). Desafios dos novos media: a nova ordem politica e comunicacional. Lisboa: Notícias.

CASETTI, F. e ODIN, R. (1990). "De la paléo-à la néo-télévision”. Communications, 51(1), pp.9-26.

CASTILHO SANTANA, F. (2010). Telenovela e Recepção: um estudo com famílias da 'classe trabalhadora' portuguesa. Tese de Mestrado, Universidade de Coimbra.

CHETA, R. (2006). "Estratégias de Sucesso na Ficção TV Nacional: O Estudo de caso das' telenovelas juvenis'", in Obercom-Research Report.

CHETA, R., e ABOIM, S. (2007). "Era uma vez... Fábulas, romances, quotidianos. Imagens da vida privada nas telenovelas portuguesas", in Working Report do Obercom, Lisboa: Obercom.

COSTA, C. C. (2000). A milésima segunda noite: da narrativa mítica à telenovela análise estética e sociológica. São Paulo: Fapesp.

COSTA, J. P. (2003). Telenovela, um modo de produção, o caso português. Lisboa: Ed. Universitárias Lusófona.

CUNHA, I. F. (2008). "Ficção televisiva e entretenimento", in XXXI Congresso Brasileiro de Ciências da Comunicação - I Colóquio Bi-Nacional de Ciências da Comunicação Brasil-Portugal, setembro 2008. Natal - RN. 
CUNHA, I. F. (2010), “Audiências e recepção das telenovelas brasileiras em Portugal”, in Comunicação, mídia e consumo. 7 (20), pp. 91 - 118.

CUNHA, I. F. (2011). Memórias da Telenovela-Programas e Recepção. Lisboa: Livros Horizonte.

CUNHA, I. F. (2012). Análise dos Media. Coimbra: Imprensa da Universidade de Coimbra.

CUNHA, I. F.; BURNAY, e CASTILHO SANTANA, F. (2010). "Portugal: Ficção Sem Crise”, in LOPES, M.I. e OROZCO, G. (Eds.) Convergêrcias e Transmidiação Da Ficção Televisiva: Obitel 2010. Rio de Janeiro: Sulina, pp. 345-380.

CUNHA, I. F.; BURNAY, e CASTILHO SANTANA, F. (2011). "Portugal: Novos Desafios", in Lopes, LOPES, M.I. e OROZCO (Eds.). Qualidade Na Ficção Televisiva e Participação Transmidiática Das Audiências. Observatório Ibero-Americano Da Ficção Televisiva Obitel. Rio de Janeiro: Sulina, pp. 447-484.

CUNHA, I. F.; BURNAY, e CASTILHO SANTANA, F. (2012). "Portugal: velhas estratégias para novos tempos", in LOPES, M.I. e OROZCO (Eds.). Transnacionalização Da Ficção Televisiva Nos Países Ibero-Americanos: Anuário Obitel 2012. Porto Alegre, pp.447-483.

DOYLE, G. (2010). "From Television to Multi-Platform Less from More or More for Less?”, in Convergence: The International Journal of Research into New Media Technologies, 16(4), pp. 431- 449.

ECO, U. (1991). Apocalípticos e Integrados. Lisboa: Difel.

ECO, U. (1994). Seis Passeios pelos Bosques da Ficção. Lisboa: Difel.

EDER, J.; JANNIDIS, F. e SCHNEIDER, R. (Eds.). (2010). Characters in fictional worlds: Understanding imaginary beings in literature, film, and other media, 3, Walter de Gruyter.

EVANS, E. (2011). Transmedia Television: Audiences. New Media And Daily Life. Nova Iorque: Routledge.

FeChine, Y.; GOUVEiA, D.; AlmeidA, C.; COSTA, M. e ESTEVÃo, F. (2011). “Transmidiação: explorações conceituais a partir da telenovela brasileira”, in LOPES, M.I.V. (Ed.). Ficção televisiva transmidiática no Brasil: plataformas, convergências, comunidades virtuais. Porto Alegre: Meridional.

FECHINE, Y. e FIGUEIRÔA, A. (2013). "Como pensar os conteúdos transmídias na teledramaturgia brasileira? Uma proposta de abordagem a partir das telenovelas 
da Globo", in LOPES, M.I.V. (Ed.). Ficção televisiva transmidiática no Brasil: plataformas, convergências, comunidades virtuais. Porto Alegre: Meridional. GENETTE, G. (1987). Discurso da Narrativa. Lisboa: Vega.

GIOVAGNOLI, M. (2011), Transmedia Storytelling: Imagery, Shapes And Techniques. Pittsburgh: Etc Press.

JENKINS, H. (2009). Cultura da convergência. São Paulo: Aleph.

JENKINS, H. (2010a), "Transmedia Storytelling and Entertainment: An annotated syllabus", in Journal of Media \& Cultural Studies, 24 (6), pp. 943-958[online]. [Acedido em 08/01/2014]. Disponível em: http://dx.doi.org/10.1080/10304312 .2010 .510599

JENKINS, H. (2010b). "How youtube became ourtube", disponível online em 'Confessions of an Aca-fan'; [online]. [Acedido em 29/11/2013]. Disponível em: http://henryjenkins.org/2010/10/how_youtube_became_ourtube.html

JOST, F. (2011). "Novos comportamentos para antigas mídias ou antigos comportamentos para novas mídias?”. in MATRIZes, 4 (2), pp. 93-109.

LACALLE, C. (2010). "As novas narrativas da ficção televisiva e a Internet", in MATRIZes, 3 (2), pp. $79-102$

LOPES, M.I. V. (2009). "Telenovela como recurso comunicativo", in MATRIZes, 3 (1), pp. 21-47.

Meyer, M. (1996). Folhetim: uma história. Editora Companhia das Letras.

MOREIRA, J. P. (2000), "Avatares da Telenovela: Para uma caracterização histórico-estrutural do género", in DAMÁSIO, M. e JORGE, R. P. (Eds). Imagens e Reflexões: Actas da $2^{a}$ Semana Internacional do Audovisual e Multimédia. Lisboa: Edições Universitárias Lusófonas, pp.70-80.

MÜLLER, E. (2009). "Where quality matters: discourses on the art of making a youtube vídeo", in VONDERAU, P. e SNICKARS, P. (Eds.). The Youtube Reader. National library of Sweden, pp. 126-139.

MURRAY, J. (1997). Hamlet on the Holodeck - The future of narrative in cyberspace. Cambridge: The MIT Press.

NEGROPONTE, N. (1995). Ser Digital. Lisboa: Caminho da Ciência.

NOGUEIRA, L. (2010). Manuais De Cinema I-Laboratório De Guionismo. Portugal: Labcom Books. 
ORTIZ, R.; BORELLI, S. e RAMOS, J.M. (1989). Telenovela: história e produção. São Paulo: Editora Brasiliense.

PEIXINHO, A. T. (2010). A epistolaridade nos textos de imprensa de Eça de Queirós. Lisboa: Fundação Calouste Gulbenkian/ FCT.

POLICARPO, V. M. (2006). Viver a telenovela: um estudo sobre a recepção. Lisboa: Livros Horizonte.

PRATTEN, R. (2011). Getting started with storytelling. Createspace.

REIS, C. (1995). "Atração Fatal: sobre a telenovela como ilusão e verdade", in REIS, C. (ed.). Discursos: Revista de Estudos de Língua e Cultura portuguesa, n.10, Coimbra: Universidade Aberta, pp.25-42.

REIS, C. (2012). "A sobrevida das personagens". [online]. [Acedido em 16/02/2013]. Disponível em: https://figurasdaficcao.wordpress.com/2012/10/01/a-sobrevida-das-personagens-3-2/

REIS, C. e LOPES, S. C. M. (2007). Dicionário de Narratologia. Coimbra: Almedina. ROSE, F. (2011). The art of immersion: How the digital generation is remaking Hollywood, Madison Avenue, and the way we tell stories. Nova Iorque: WW Norton e Company.

ROSS, S. M. (2009). Beyond the box: Television and the Internet. Wiley. Com.

RTP (2011), Lei da Televisão, Lei n. ${ }^{\circ}$ 31-A/98, de 14 de julho. [online]. [Acedido em 05/09/2013]. Disponível em: http://www.rtp.pt/wportal/grupo/leitv.htm

SCOLARI, C. A.; M. Jiménez, M. Guerrero (2012). "Narrativas Transmediáticas En España: Cuatro Ficciones En Busca De Un Destino Cross-Media”, in Comunicación Y Sociedad, 25 (1), pp. 137-163.

SCOLARI, C. A. (2011), "A construção de mundos possíveis se tornou um processo coletivo", in MATRIZes. 4 (2), pp. 127-136.

SCOLARI, C. A. (2013). Narrativas Transmedia: Cuando todos los medios cuentan. Deusto. TEVES, V. H. (2007). RTP, 50 anos de História. Lisboa: RTP.

TORRES, E. C. (2012). "Folhetim, uma história sem fim: dos primeiros jornais de massas à Internet", in Lumina, 6(2).

TODOROV, T. (1970). As estruturas narrativas. São Paulo: Editora Perspectiva

TRAQUINA, N. (1997). Big Show Media: viagem pelo mundo do audiovisual português. Lisboa: Notícias. 
TRAQUINA, N. (2000). O poder do jornalismo: análise e textos da teoria do agendamento. Coimbra: MinervaCoimbra.

TURKLE, S. (1989). O segundo eu: os computadores e o espírito bumano. Lisboa: Presença.

TURKLE, S. (1997). A vida no ecrã - a identidade na era da Internet. Lisboa: Relógio d'água.

VILCHES, L. (2003). A migração digital. São Paulo: Edições Loyola. 
(Página deixada propositadamente em branco.) 


\section{NOTAS BIOBIBLIOGRÁFICAS DOS/AS AUTORES/AS}

\section{Alciane Baccin}

Doutoranda da Universidade Federal do Rio Grande do Sul (UFRGS/Brasil), em estágio doutoral sanduíche na Universidade da Beira Interior (UBI/Portugal). Investigadora dos Grupos de Pesquisas: Jornalismo Digital (UFRGS) e Estudos de Jornalismo (Unisinos). Bolsista CAPES - PDSE, Processo BEX: 8806/14-4. E-mail: alcianebaccin@gmail.com

\section{Aletheia Patrice Rodrigues Vieira}

Mestra em Jornalismo e Sociedade pelo Programa de Pós-Graduação da Faculdade de Comunicação - PPG/FAC da Universidade de Brasília - UnB, especialista em Jornalismo Político pela Universidade Gama Filho - UFG e graduada em Comunicação Social - Jornalismo pela Universidade Federal do Pará - UFPA. Email: aletheiavi@gmail.com

\section{Ana Paula Arnaut}

Ana Paula Arnaut nasceu a 12 de junho de 1964. É doutorada com agregação pela Universidade de Coimbra, onde leciona Literatura Portuguesa Contemporânea. Publicou Memorial do Convento. História, Ficção e Ideologia (1996), Post-Modernismo no Romance Português Contemporâneo: Fios de Ariadne-Máscaras de Proteu (2002), Homenagem a Cristóvão de Aguiar: 40 anos de vida literária (org.) (2005), José Saramago (2008), Entrevistas com António Lobo Antunes. 1979-2007. Confissões do Trapeiro (ed.) (2008), António 
Lobo Antunes (2009), António Lobo Antunes: a Crítica na Imprensa. 1980-2010. Cada um Voa como Quer (ed.) (2011). As mulheres na ficção de António Lobo Antunes. (In)variantes do feminino) (2012), Viagens do Carnaval: no espaço, no tempo, na imaginação (coedição com Maria Aparecida Ribeiro) (2014). Tem também artigos publicados em inúmeras revistas nacionais e internacionais.

\section{Ana Teresa Peixinho}

Nasceu em Coimbra em 1971. É doutorada pela Universidade de Coimbra em Ciências da Comunicação e é Professora Auxiliar da Faculdade de Letras da mesma Universidade. Investigadora do Centro de Estudos Interdisciplinares do Século XX (CEIS20) e do Centro de Literatura Portuguesa (CLP), tem-se dedicado aos estudos queirosianos, no âmbito dos quais integra o projeto de Edição Crítica da obra de Eça de Queirós. Também integra o grupo de trabalho do projeto "Figuras da Ficção", coordenado por Carlos Reis, onde tem desenvolvido investigação sobre narrativas e personagem.

\section{Bruno Araújo}

Bruno Araújo é doutorando do Programa de Pós-Graduação em Comunicação e Sociedade da Universidade de Brasília. Mestre e licenciado em Comunicação e Jornalismo pela Universidade de Coimbra, onde defendeu a dissertação "Media, Justiça e Espaço Público: a cobertura jornalística do julgamento do mensalão em Veja e Época”. É investigador do Núcleo de Estudos em Mídia e Política e do Grupo de Pesquisa Cultura, Mídia e Política, ambos da Universidade de Brasília. É membro colaborador do Centro de Estudos Interdisciplinares do Século XX da Universidade de Coimbra (CEIS20).

\section{Carlos Reis}

Carlos Reis é professor catedrático da Universidade de Coimbra, sendo especialista em Literatura Portuguesa dos séculos XIX e XX, 
sobretudo no domínio dos estudos queirosianos. Autor de cerca de vinte livros, ensinou em diversas universidades da Europa, dos Estados Unidos e do Brasil. É doutor honoris causa pela Pontifícia Universidade Católica do Rio Grande do Sul. Dirige a Edição Crítica das Obras de Eça de Queirós e coordenou a História Crítica da Literatura Portuguesa (9 vols.). Foi diretor da Biblioteca Nacional, reitor da Universidade Aberta, presidente da Associação Internacional de Lusitanistas e da European Association of Distance Teaching Universities. É membro correspondente da Real Academia Española e da Academia das Ciências de Lisboa. Presentemente é coordenador científico do Centro de Literatura Portuguesa, onde coordena o projeto de investigação "Figuras da Ficção".

\section{Célia Mota}

Célia Maria Ladeira Mota é doutora em Comunicação, pesquisadora do Programa de Pós-Graduação em Comunicação da Universidade de Brasília. Autora dos livros Narrativas Midiáticas e Narrativas da Identidade Brasileira, é integrante do grupo de pesquisa Cultura, Mídia e Política da UnB, e associada à SBPJOR, Sociedade Brasileira de Pesquisadores em Jornalismo. Email: cladmota@gmail.com

\section{Daniela Maduro}

Daniela Côrtes Maduro é mestre em Estudos Anglo-Americanos. Em 2014, finalizou o Doutoramento em Materialidades da Literatura na Universidade de Coimbra, durante o qual contou com o apoio de uma Bolsa Individual de Doutoramento concedida pela Fundação para a Ciência e a Tecnologia. O seu trabalho de investigação centra-se na área das humanidades digitais. Tem escrito sobre literatura eletrónica, ficção científica, cibercultura, materialidades da literatura, teoria da literatura, narratologia, arquivo e curadoria de obras literárias. Presentemente, encontra-se a desenvolver o seu projeto de pós-doutoramento na Universidade de Bremen. 


\section{Fernanda Castilho}

Pós-doutoranda na Escola de Comunicações e Artes da Universidade de São Paulo (ECA-USP). Doutora em Ciências da Comunicação e Mestre em Comunicação e Jornalismo, ambos pela Universidade de Coimbra. Professora da Faculdade de Tecnologia do Governo do Estado de São Paulo, FATEC. Investigadora do CETVN (Centro de Estudos de Telenovela) e do OBITEL (Observatório Ibero-Americano de Ficção Televisiva). Membro do CIMJ (Centro de Investigação Media e Jornalismo).

\section{Fernando Resende}

Doutor em Ciências da Comunicação pela Universidade de São Paulo, Pós-doutorado na School of Oriental and African Studies (SOAS - University of London - Inglaterra), Mestre em Estudos Literários pela Universidade Federal de Minas Gerais e graduado em Comunicação Social - Jornalismo pela Pontifícia Universidade Católica de Minas Gerais. Professor do curso de Estudos de Mídia e do Programa de Pós-Graduação em Comunicação do Departamento de Mídia e Estudos Culturais da Universidade Federal Fluminense (UFF), onde coordena o [LAN] Laboratório de Experimentação e Pesquisa de Narrativas da Mídia. Coordenador local do Erasmus Mundus Joint Doctorate - Cultural Studies in Literary Interzones (UFF/Bergamo/Tübingen/Perpignan/Delhi) e do Projeto de Pesquisa Literary Cultures of the Global South (DAAD/Tübingen Universität, Alemanha). Pesquisador associado do Centre for Film and Media Studies e do Centre for Palestinian Studies da School of Oriental and African Studies (SOAS), da University of London, Inglaterra. Professor visitante na Université de Perpignan, França e na Universität Tübingen, Alemanha. Pesquisador PQ/CNPq interessado nos estudos das narrativas de conflito e dos movimentos diaspóricos, com ênfase em teoria e estudos da Comunicação e do Jornalismo, atuando principalmente nos temas: jornalismo, discurso, narrativas, cultura, comunicação, 
alteridade, conflito e Oriente Médio. Membro de Comitês Científicos de diversos periódicos nacionais e internacionais, com vários artigos publicados em revistas científicas e capítulos de livros.

Link para CV completo e lista de publicações: http://lattes.cnpq. br/5520975095445897

\section{Hélder Prior}

Hélder Prior é Pós-Doutor pela Faculdade de Comunicação da Universidade de Brasília (PNPD/CAPES). É Doutor Europeu em Ciências da Comunicação pela Faculdade de Artes e Letras da Universidade da Beira Interior (UBI). Licenciou-se em Ciências da Comunicação, especialidade em Jornalismo, na mesma instituição, em 2007. É membro integrado do LabCom.IFP da UBI e investigador colaborador do Observatorio Iberoamericano de la Comunicación da Universidade Autónoma de Barcelona, instituição onde desenvolveu parte do trabalho doutoral. Atualmente, é investigador de Pós-Doutoramento na Fundação para a Ciência e a Tecnologia (FCT).

\section{Ivan Satuf}

Doutor em Ciências da Comunicação na Universidade da Beira Interior (UBI/Portugal) e investigador do LabCom.IFP. Graduado em Jornalismo (PUC Minas/Brasil) com especialização e mestrado em Comunicação Social (UFMG/Brasil). Possui experiência docente em cursos de Jornalismo e na coordenação de produtos laboratoriais (jornal, revista, site). Atuou como jornalista profissional nos Diários Associados, exercendo as funções de repórter no jornal Estado de Minas e produtor multimídia e editor de conteúdos digitais nos portais on-line Uai e EM.com. E-mail: ivsatuf@gmail.com

\section{Jacinto Godinho}

Jacinto Godinho, doutorado em Ciências da Comunicação pela FCSH da Universidade Nova de Lisboa, é professor auxiliar do 
Departamento de Ciências da Comunicação da UNL onde leciona, desde 1993, as disciplinas Teoria da Reportagem, Discurso dos Media e Géneros Televisivos. Entre várias outras publicações destacam-se os livros: As origens da reportagem - Imprensa (2009) e As origens da reportagem - Televisão (2011).

Jacinto Godinho é também jornalista dos quadros da RTP (Rádio e Televisão de Portugal) desde 1988. Como repórter especial fez vários trabalhos de investigação premiados, como "Tráfico de hormonas para a carne de vaca" (1993) e "Caça aos golfinhos nos Açores" (1994). Produziu e realizou várias séries documentais, como é o caso de "Memórias do Cinema Português - 100 anos de história" (2001); "Ei-los que Partem - Uma história da Emigração Portuguesa" (2006), "Os Últimos Dias da PIDE" ( 2015) e "A Pide Antes da Pide" (2016). Venceu por duas vezes o mais importante e prestigiado galardão de jornalismo atribuído em Portugal - o Prémio Gazeta do Clube de Jornalistas.

\section{João Canavilhas}

Doutor pela Universidade de Salamanca (Comunicación, Cultura y Educación) com a tese "Webperiodismo: propuesta de modelo periodístico para la Web”. É professor associado na UBI e investigador Labcom.IFP. Participa em projetos de investigação nacionais e internacionais, sendo autor de mais de sete dezenas de capítulos de livro e artigos em revistas científicas nacionais e internacionais. E-mail: jc@ubi.pt

\section{Leylianne Alves Vieira}

Leylianne Alves Vieira é doutoranda pelo Programa de PósGraduação em Comunicação da Universidade Federal de Minas Gerais (UFMG). Mestra pelo Programa de Pós-graduação em Comunicação da Universidade de Brasília (UnB). Integrante dos Grupos de Pesquisa 'Estudos Fotográficos' (UFCA) e 'Cultura, Mídia e Política' (UnB). Email: leylianne.av@gmail.com. 


\section{Liziane Soares Guazina}

Graduada em Comunicação - Jornalismo (1997), mestre em Comunicação e Cultura (2001) e doutora em Comunicação pela Universidade de Brasília (2011). Coordenadora do Núcleo de Estudos sobre Mídia e Política (NEMP/UnB), líder do Grupo de Pesquisa Cultura, Mídia e Política. Email: lguazina@unb.br

\section{Luís G. Motta}

Luiz G. Motta é jornalista, mestre em jornalismo pela Indiana University (USA), doutor em comunicação pela University of Wisconsin (USA), com estágio de pós-doutorado na Universitat Autònoma de Barcelona (Espanha). É professor-titular da Universidade de Brasília (UnB), professor-visitante da Universidade Federal de Santa Catarina (UFSC) e pesquisador do Conselho Nacional de Desenvolvimento Científico e Tecnológico (CNPq/ Brasil). Orientou mais de 50 dissertações de mestrado e teses de doutorado, publicou inúmeros artigos, livros e capítulos de livros. Suas pesquisas se concentram no campo da narrativa jornalística. Foi expert internacional da Fundação Frederick Ebert (Alemanha), professor do Centro Internacional de Estudios Superiores de Periodismo para América Latina (Equador), consultor do UNICEF (Moçambique, Africa). Foi Secretário de Estado (Distrito Federal, Brasil) e Secretário Nacional de Cultura (MINC, Brasil). Foi repórter, editor, produtor independente de vídeo, diretor e apresentador de programa de televisão.

\section{Maria Augusta Babo}

Maria Augusta Babo é Professora Associada com Agregação, no Departamento de Ciências da Comunicação, da Faculdade de Ciências Sociais e Humanas - Universidade Nova de Lisboa, onde leciona nas áreas de: Textualidades, Cultura e Subjetividade e orienta teses de Doutoramento e Mestrado. 
É Presidente do Centro de Estudos de Comunicação e Linguagens. Integra a Comissão Diretiva do Doutoramento FCT em Estudos de Comunicação: Tecnologia, Cultura e Sociedade. Participa em colóquios e congressos da especialidade. Das publicações de 2015 destacam-se: "As intermitências do íntimo", in: Deslocações da intimidade, Coordenação de Né Barros e Filipe Martins, Porto, Family Film Project, Balleteatro/ Instituto de Filosofia, Grupo Estética, Política e Artes (UP); ISBN 978-989-96484-3-2, pp. 17-26.

Co-coordenadora, com Maria Lucília Marcos e Ricardo Santos, Jacques Derrida, Lisboa: CECL/UNYLEYA, ebook, Colecção Cultura, Media e Artes N³, 294 PGS, ISBN Portugal9789899850347 | ISBN Brasil 9788544101452. 
RESUMOS / ABSTRACTS DOS ARTIGOS

PALAVRAS-CHAVE / KEY WORDS 
(Página deixada propositadamente em branco.) 


\title{
Carlos Reis, Woody Allen ou a ficção como jogo: o caso Zelig Woody Allen on the fiction as a game: Zelig Case
}

\author{
Resumo \\ No presente texto, parto do filme de Woody Allen, Zelig (1983), para ana- \\ lisar um conjunto de questões colocadas por aquele filme e por outros \\ que integram a filmografia do autor. Assim, os protocolos constitutivos da \\ narrativa e os procedimentos de transgressão ficcional que eles envolvem \\ ocuparão aqui um lugar de destaque, tendo em atenção o propósito da- \\ quele filme e certos géneros narrativos a que ele está associado: biografia, \\ reportagem, documentário, etc. \\ Articula-se com isto o problema da construção da personagem, num lugar \\ indeciso em que ficcionalidade e não-ficcionalidade são objeto de insis- \\ tente subversão paródica. Para além disso, estarão em equação efeitos \\ cognitivos determinados pelo recurso à hibridização de géneros e às de- \\ rivas metalépticas que eles consentem, bem como pela lógica funcional e \\ sociocultural que é própria das narrativas mediáticas.
}

\section{Palavras-chave}

Narrativa; filme; personagem; metalepse; ficcionalidade.

\section{Key words}

Narrative; film; character; metalepsis; ficcionality. 
(Página deixada propositadamente em branco.) 


\section{Luís G. Motta, Análise pragmática da narrativa: teoria da narrativa como teoria da ação comunicativa}

\section{Resumo}

Este capítulo propõe um esboço conceitual e metodológico para estudos que pretendem interpretar as narrativas como atos de fala. O capítulo sugere que narrativas não são obras fechadas sobre si mesmas, mas processos protagonizados por atores sociais vivos e ativos: são uma mediação entre um enunciador e um destinatário concretos. Sao simultaneamente, no ato de comunicação narrativo, uma mediação entre um mundo referente prefigurado e um outro mundo refigurado. A teoria apropriada para essas singulares mediações é a teoria da ação, de onde se devem derivar os procedimentos de análise. As narrativas são aqui entendidas como objetos de batalhas discursivas nas contraditórias disputas pela configuração de representações 'mais autênticas' da realidade social. Nessas batalhas discursivas a tensão entre a força argumentativa dos interlocutores se exerce e se pratica. Após o esgotamento das análises imanentistas devido ao seu desprezo pelo contexto social e a performance dos interlocutores, o projeto epistemológico aqui sugerido adquire urgente atualidade diante da enxurrada de narrativas transmidiáticas que se derrama sobre nós na pós-modernidade, entretecendo uma teia virtual de significados na qual estamos todos enredados. O capítulo propõe a análise pragmática como procedimento metodológico capaz de dar conta dos usos argumentativos que os interlocutores fazem da narrativa em contextos comunicativos específicos. O capítulo finaliza dedicando atenção a dois aspectos particulares da análise pragmática: 1) o protagonismo dos interlocutores, sua vontade de fazer sentido, e suas estratégias argumentativas em concretas correlações de forças; 2) os círculos dêiticos concêntricos como um procedimento metodológico capaz de tornar mais rigorosa a identificação de traços dos interlocutores no texto da narrativa em análise.

\section{Palavras-chave}

Narrativas; atos de fala; teoria da argumentação; pragmática; dêiticos. 


\title{
Pragmatic analisys of narrative: narrative theory as communicative action theory
}

\begin{abstract}
This chapter suggests a conceptual and methodological outline for interpretive analysis of narratives as speech acts. The essay suggests that narratives are not closed discourses, but communicative processes set forward by active social actors: narrative is mediation between a concrete enunciator and a concrete addressee. They simultaneously are, in the narrative communication act, a mediation process between a referential pre-figured world and another re-figured world. The appropriated theory for these singular mediations is the theory of action, from where the analytical procedures must originate. Narratives are here understood as argumentative objects of battles in the contradictory disputes for the configuration of 'more authentic' social representations of reality. In these argumentative battles the tension among the illocutionary forces are exerted and practiced. After the exhaustion of the imanentist narrative analysis due to their disdain for the social context and the active performance of the interlocutors, the epistemological project here suggested acquires urgent actuality because of the torrent of transmedia narratives that scatters over society in post-modern times intertwining a virtual symbolic texture where we are all interlaced. The chapter proposes a pragmatic analysis as the methodological procedure able of facing the problematic use of argumentative discourses performed by interlocutors in specific communication contexts. To conclude, the chapter renders special attention to two aspects of the pragmatic analysis: 1) the active protagonism of interlocutors, their desire to make sense, and their argumentative strategies when facing opposed forces; 2) the deistic concentrical circles as a methodological procedure capable of making more systematic the identification of traces of the social context in the narrative under analysis.
\end{abstract}

\section{Key words}

Narratives; speech acts; argumentation theory; pragmatics; deixis. 


\section{Maria Augusta Babo, Considerações críticas sobre a máquina narrativa}

\section{Resumo}

A narrativa é uma máquina de conferição de sentido à experiência, ao vivido, ao acontecimento. É uma máquina semiótica na medida em que o seu funcionamento gera sentido, é produtor de sentido sobre o real. Enquanto máquina, ela integra um conjunto de componentes que lhe conferem estatuto narrativo.

Se é certo que a máquina narrativa exige um acontecimento disruptivo também é certo que ela retira ao acontecimento o seu carácter de contingência para o remeter à lógica da causalidade e da finalidade última - a clausura narrativa provocada pelo desenlace.

Na sua expressão mais aberta, a narrativa comporta um juízo de natureza reflexiva. O narrado incorpora um juízo que ao mesmo tempo se distancia do mundo e o interpreta, avalia esse mundo que fabrica. Assim pode concluir-se que entre narrativas ficcionais e a narrativas factuais não há diferenças do ponto de vista do dispositivo configurador. A questão colocar-se-á, antes, ao nível da possibilidade ou não de referir o mundo. Questão que aqui se pretende discutir.

\section{Palavras-chave}

Máquina narrativa; acontecimento; distanciamento; produção de sentido. 


\title{
Critical considerations on narrative machine
}

\begin{abstract}
The narrative is a machine to propose meaning to experience, to events from life. It is a semiotic machine because it generates sense; it produces meaning over the real world. As a machine, it includes a set of components that give narrative status.
\end{abstract}

If it is true that the narrative machine requires a disruptive event is also true that it removes the event its contingency character to refer to the logic of causality and the ultimate goal - the narrative closure caused by the end.

In its open expression, the narrative includes a judgment of reflective nature. The narrated incorporates a judgment that, at the same time, takes a distance from the world and interprets it; it evaluates the world that it produces. Thus, it can be concluded that between fictional narratives and factual narratives there is no difference from the point of view of the configurator device. The question will be put, differently, in terms of the possibility to mention the world. Question that we pretend to discuss here.

\section{Key words}

Narrative machine; event; distance; production of meaning. 


\section{Fernando Resende, Imprensa e conflito: narrativas de uma geografia violentada}

\section{Resumo}

Este artigo busca discutir questões relacionadas à imprensa, considerando a narrativa como um problema e o território palestino como um desafio. Seu argumento central é de que as camadas de estereótipos e os binarismos que hoje dão forma ao conflito precisam ser constantemente escavadas, debatidas e confrontadas. A partir da conceção de um quadro histórico-cultural que hoje torna possível pensar o jornalismo pelo paradigma relacional, seu objetivo principal, menos do que se deter a uma crítica sobre os reducionismos a que está submetido o discurso da imprensa, é contribuir para uma reflexão acerca da potência da narrativa diante, particularmente, das complexidades que regem os chamados "conflitos de longa duração". No território palestino, uma geografia violentada, infindáveis tramas tecem um conflito que acontece, pelo menos, desde o início do século XX. Um território tão cruelmente devastado nos coloca diante de experiências humanas que precisam ser consideradas em um âmbito muito mais amplo e complexo do que a perspetiva que conforma as estereotipias que, de modo geral, são produzidas pela imprensa. E são os estudos da narrativa que tornam possível esta reflexão cujo propósito, além de tudo, é entender a complexidade que se inscreve no território palestino como fundamental não só para nos fazer compreender algumas das limitações do jornalismo, como também para viabilizar uma reflexão sobre as possibilidades de produção de resistências pela linguagem. Sob esta ótica, esta reflexão propõe o entendimento de que produzir narrativa é um gesto estético de produção de cultura, o que no caso da Palestina é uma constatação de caráter eminentemente político. Como tem sido / pode ser narrado o conflito Israel/Palestina é, portanto, uma pergunta relevante, pois o problema com o qual este artigo se defronta tem como princípio o que nos leva a compreender quão complexos são os modos 
de inserção dos sujeitos e dos poderes que naquele território se configuram. Nesse sentido, através da análise de uma reportagem, em forma de diário, produzida por uma jornalista brasileira que viaja pela Palestina, e da comparação com outras narrativas em sites e um documentário, este artigo salienta a importância da produção de narrativas mais atentas aos efeitos político-culturais que o conflito produz; narrativas que tratem menos do esforço de explicação do acontecimento propriamente dito, e mais da representação de ordens complexas e paradoxais que ali se inscrevem. É por este viés que a narrativa, através da imprensa, tem um papel crucial, ela nos ajuda a desvelar os desdobramentos e as contradições que o conflito produz, fazendo-nos ver os meandros que ele engendra. O olhar lançado neste artigo, portanto, assume uma dimensão política e estética, instâncias absolutamente amalgamadas tanto na imprensa como no mundo que hoje conhecemos.

\title{
Palavras-chave:
}

Imprensa; conflito; representação; Palestina.

\section{Press and conflict: narratives of violated geography}

\begin{abstract}
This article discusses issues related to the press, considering narrative as a problem and the Palestinian territory as a challenge. Its central argument is that the layers of stereotypes that today form the conflict need to be constantly dug, discussed and compared. From the conception of a historical-cultural framework that now makes it possible to think of journalism by the relational paradigm, its main goal, less than a critique of the reductionism to which the discourse of the press is submitted, is to contribute to a reflection about the power of narrative, particularly when considering the complexities inscribed in the so-called "long-term conflicts". In the Palestinian territory, a violated geography, endless plots weave a conflict that
\end{abstract}


happens, at least since the beginning of the $20^{\text {th }}$ Century. A territory so cruelly devastated urges us to consider human experiences in a form much more complex and broader than the ones that build stereotypies, which are produced by the press in general. And it is the field of narrative studies that make possible this reflection, whose purpose, above all, is to understand the complexity inscribed in the Palestinian territory as fundamental not only to make us understand some of the limitations of journalism, but also to evoke a reflection about ways to produce resistances through the use of language. From this perspective, this reflection takes the production of narratives as an aesthetic gesture that produces culture, which in the case of Palestine is an eminently political consideration. How the Israel/ Palestine conflict has been / can be narrated is thus an important question, once the problem faced in this article has it as a principle that leads us to understand how complex it is the insertion and configuration of subjects and powers within that territory. In this sense, through the analysis of an account produced by a Brazilian journalist traveling through Palestine, and by comparing it with other narratives in sites and in a documentary, this article highlights the importance of producing stories more attentive to the political and cultural effects produced by that conflict; narratives that deal less with the event explanation itself, and more with the representation of its paradoxical and contradictory orders. Press narrative, this way, has a crucial role, it helps us to unravel the consequences and contradictions that the conflict produces, making us see the intricacies that it engenders. This article, therefore, takes on a political-aesthetic dimension, instances absolutely amalgamated both in the press and in the world we know nowadays.

\section{Key words:}

Press; conflict; representation; Palestine. 
(Página deixada propositadamente em branco.) 


\section{Bruno Araújo, Estudos narrativos e teoria do jornalismo: a narrati- va de Veja e IstoÉ sobre uma manifestação de estudantes da USP}

\section{Resumo}

Este artigo assume que, em virtude da avalanche de informações com que os media tradicionais confrontam os cidadãos todos os dias, será preciso reafirmar a ideia de que o jornalismo não representa ou espelha a realidade social, política e cultural de uma sociedade. Na verdade, como construtores de narrativas, os jornalistas operam códigos de estruturação textual e paratextual que, aliados àquilo que conhecem do mundo, a diversos constrangimentos profissionais e ideologias, imputam significações construídas aos acontecimentos. Nesse contexto, esta reflexão cruza contributos dos estudos narrativos com as teorias construtivistas do jornalismo, com especial foco na teoria do newsmaking, para evidenciar a influência do modo narrativo sobre a textualidade jornalística. Trata-se de discutir o grau de narratividade inerente ao discurso jornalístico, demonstrando que, assim como em outros tipos de narrativa, a narrativa jornalística constrói realidades múltiplas, com significações que oscilam de acordo com estratégias discursivas mobilizadas pelo enunciador, sem que isso implique necessariamente a negação do seu dever de referencialidade do real. Como trabalho analítico, recorre-se a ferramentas da Análise Crítica do Discurso, combinadas com categorias da narrativa, para analisar reportagens publicadas nas revistas brasileiras Veja e IstoÉ a propósito de uma manifestação de estudantes da Universidade de São Paulo ocorrida em outubro de 2011.

\section{Palavras-chave:}

Narrativa; jornalismo; newsmaking; construção da realidade; Veja; IstoÉ; Universidade de São Paulo. 


\title{
Narrative studies and journalism theory: the report of Veja and Istó́ about a demonstration
}

\begin{abstract}
This article assumes that, because of the avalanche of information that traditional media confront us every day, you need to reaffirm the idea that journalism does not represent or mirrors the social, political and cultural life of a society. In fact, as narratives builders, journalists operate textual and non-textual structure codes that, allies what they know of the world, various professional and ideological visions constraints, give meaning to events. In this context, this article crosses contributions of narrative studies with constructivist theories of journalism, with special focus on newsmaking theory, to show the influence of narrative mode over journalistic textualities. It is to discuss the degree of narrativity inherent in the journalistic discourse, demonstrating that, as in other types of narrative, journalistic narrative builds multiple realities with meanings that vary according to discursive strategies mobilized by enunciating involved by ideological devices. As analytical work, it refers to tools of Critical Discourse Analysis, combined with narrative categories, to analyze articles published in Brazilian magazines Veja and IstoÉ on a demonstration by students from the University of São Paulo occurred in October 2011.
\end{abstract}

\section{Key words}

Narrative; journalism; newsmaking; construction of reality; Veja; IstoÉ, University of São Paulo. 
Hélder Prior, Jornalismo, Narrativas e Escândalos

\begin{abstract}
Resumo
O trabalho sobre Jornalismo, Narrativas e Escândalos é uma tentativa de compreender os escândalos mediáticos à luz dos pressupostos da teoria da narrativa. Com efeito, num primeiro momento procuraremos definir o conceito "escândalo" e identificar as suas características tendo em conta o contributo dos principais autores que trabalharam o fenómeno. Posteriormente, iremos tecer algumas considerações sobre as relações entre o escândalo mediático e a narratologia, estabelecendo um quadro teórico que nos possibilitará, no terceiro ponto deste ensaio, realizar uma análise pragmática do escândalo Face Oculta, colocando em evidência o valor expressivo do escândalo enquanto narrativa mediática. Na nossa perspetiva, os escândalos podem ser interpretados como narrativas que têm um enredo, episódios principais e secundários, personagens que realizam papéis ou funções na trama e efeitos poéticos ou estéticos inerentes às estratégias enunciativas do jornalista no momento de reconfigurar o acontecimento numa experiência mediática.
\end{abstract}

\title{
Palavras-chave
}

Escândalo; Jornalismo; Narratividade; Face Oculta. 
Journalism, narratives and scandals

\begin{abstract}
The work on Journalism, Narratives and Scandals seeks to address de relationship between the field of journalism and the narrative theory. Indeed, first of all we will try to define the concept "scandal" and identify its characteristics. Subsequently, we will try to establish a theoretical and conceptual framework of analysis of mediated scandals that enable us, on the third part of this work, analyze and deconstructing the portuguese Face Oculta scandal. From our point of view, the political scandals are complex narratives that develop in the press, and may be interpreted as "stories" that have a plot, a coherent whole, a specific temporal order, episodes, characters, turning points and meaning effects.
\end{abstract}

\title{
Key words
}

Scandal; Journalism; Narrativity; Face Oculta. 


\section{Jacinto Godinho, A minha vida não dava um filme: ensaio de desconstrução da reportagem entre a literatura e o jornalismo My life is not like a movie; essay on descontruction of reporting between literature and journalisme}

\section{Resumo}

Apesar de ser considerada, entre os jornalistas, como a "arte nobre do jornalismo", a reportagem tem sem dúvida um estatuto menor no painel das narrativas modernas, especialmente se a compararmos com as mais relevantes categorias da literatura (novela, conto, poema,) do cinema (filme, documentário) do teatro ou da música (ópera), por exemplo.

Não que a reportagem seja uma narrativa menor (apesar de nos últimos anos ter vindo a ceder espaço nos media para o comentário), mas porque, ecoando Foucault, nas formações discursivas de cada época constitui-se uma escala de valores entre saberes originada a partir do jogo do poder. A cultura não celebra as reportagens e os seus autores da mesma forma que as ficções literárias e cinematográficas distinguidas com prémios de visibilidade planetária como o Nobel ou os Oscar.

Fora do campo jornalístico não há reportagens que façam história, que figurem nos livros de escola. Em busca de estatuto, alguns repórteres tornam-se autores de livros de ficção. Outros publicam as suas reportagens em livros. Para muitos destes jornalistas o treino de escrita de reportagem é assumido, com orgulho, como um patamar essencial para se tornarem escritores, ou seja, praticam a reportagem como etapa antes da literatura. Mas não deveria ser antes o oposto, ou seja, o ensaio livre da literatura como antecâmara para a difícil, complexa e muito responsável escrita do real? Justifica-se, portanto, iniciar esta reflexão analítica com a pergunta já antes formulada por Elisabeth Eide em What novels can do, and journalism can not? ou seja o que conseguem as novelas que o jornalismo não consegue? Uma outra forma de colocar o problema é questionar por que dizemos normalmente "a minha vida dava um filme" e não dizemos "a minha vida dava uma reportagem". 
Porque nunca conseguiram os repórteres ter lugar nos panteões da cultura se a matéria das suas histórias é a vida real e tantas vezes o alimento dos romancistas?

Como resolver o paradoxo de o jornalismo e de o poder mediático serem centrais no espaço público moderno e mesmo assim não conseguirem "fazer ver e fazer falar" (Deleuze, 1986) as suas melhores obras na história?

\section{Palavras-chave}

Reportagem; jornalismo; literatura; ficção; legein.

\section{Key words}

Report; journalism; literature; fiction; legein. 


\title{
Ana Paula Arnaut, A palavra em movimento: a adaptação para ci- nema de "Embargo" e de A Jangada de Pedra de José Saramago
}

\author{
Resumo \\ Partindo da adaptação para cinema do conto "Embargo" e do romance \\ A Jangada de Pedra, de José Saramago, propomo-nos avaliar a forma \\ como a problemática da traição ao texto-fonte se esbate se tivermos em \\ mente o "«espírito" do livro", ou, em termos mais abrangentes, o espírito \\ da obra saramaguiana.
}

\section{Palavras-chave}

Fidelidade; traição; ideologia.

The word in motion: the cinema adaptation of "Embargo" and “A Jangada de Pedra” by José Saramago

\begin{abstract}
The analysis of the cinema adaptation of the short story "Embargo" and of the novel The Stone Raft, by José Saramago, will allow us to evaluate how the issues regarding the unfaithfulness to the original text will lessen if we keep in mind the "sspirit" of the book, or, in a broader sense, the spirit of the work of the author.
\end{abstract}

\section{Key words}

Fidelity; unfaithfulness; ideology. 
(Página deixada propositadamente em branco.) 


\section{Ana Teresa Peixinho e Bruno Araújo, A narrativa da desconfiança na política: a figuração do político}

\section{Resumo}

No texto que o leitor tem em mãos, discutimos como os valores que constituem a cultura política brasileira, especialmente o valor da desconfiança na política, se convertem em estratégias retórico-narrativas fundamentais para a construção da imagem de atores políticos nos media.

Partindo de uma reflexão acerca do conceito de personagem mediática, chamamos a atenção para a impossibilidade de os media transferirem, para o âmbito de suas narrativas, toda a complexidade inerente à dimensão ontológica dos seres retratados. Em vez disso, ao assumirem o estatuto de personagens mediáticas, os políticos são submetidos a um processo de estereotipia que se alimenta de um conjunto de crenças socialmente partilhadas sobre a atividade política e que influenciam na construção mediática da imagem desses atores na esfera pública. Desse processo, resulta uma imagem reduzida a traços identificadores que constituem perfis muitas vezes esquemáticos e incompletos, a partir dos quais o público formará a sua opinião.

Como campo de exploração empírica, adotamos o filme brasileiro O Candidato Honesto, lançado em outubro de 2014, num momento em que o Brasil vivia um período eleitoral. Cruzando algumas das mais importantes categorias narrativas de construção de personagens mediáticas - caricatura, tipificação, figuração e metalepse - o texto analisa os procedimentos que incidiram na construção da imagem do protagonista João Ernesto Praxedes, um político corrupto, que se apresenta, no filme, como candidato à Presidência da República pelo Partido da Ética Democrática Nacional.

A análise demonstra que o modo de figuração da personagem não apenas carrega fortes resquícios da cultura política brasileira, mas contribui efetivamente para o reforço e a naturalização de determinados valores, por meio da exploração de temas e de sentidos de maneira genérica e estereotipada. Convertido em personagem-tipo - subcategoria narrativa 
que se caracteriza por um alto poder representativo devido aos procedimentos metaléticos que a constituem-, João Ernesto Praxedes extrapola a diegese, transformando-se em autêntico representante da classe política brasileira, apresentada, na narrativa cinematográfica, como corrompida e alheia ao interesse público.

\title{
Palavras-chave
}

Personagem mediática; figuração; narrativa; política.

\section{The narrative of distrust in politics: the figuration of politician}

\begin{abstract}
In this text that the reader has at hand, we discussed how the values that constitute the Brazilian political culture, especially the value of distrust in politics, become fundamental rhetorical-narrative strategies to build the image of political actors in the media.

Starting from a reflection on the concept of media character, discussed the impossibility of the media transferred to the scope of their narratives, all the complexity inherent in the ontological dimension of the depicted beings. Instead, by assuming the status of media characters, politicians are subjected to stereotyping process that feeds a set of socially shared beliefs about political activity and influence the media image building of these actors in the public sphere. This process results in an image reduced to identifying traits that are profiles often sketchy and incomplete, from which the public will form your opinion.

Empirically, we will adopt the Brazilian film «O Candidato Honesto», launched in October 2014, when Brazil was an electoral period. Crossing some of the most important narrative categories of building media characters - cartoon typing, figuration and metalepsis - this text analysis procedures that focused on the protagonist's image construction João Ernesto Praxedes, a corrupt politician who appears in the film as candidate
\end{abstract}


to the Presidency of the Party of the Democratic National Ethics.

The analysis shows that the figuration of the character not only carries strong traces of Brazilian political culture, but effectively contributes to the strengthening and naturalization of certain values through the exploration of themes and meanings of generic and stereotypical way. Converted to character-type - sub-narrative category that is characterized by a high representative power -, João Ernesto Praxedes extrapolates the diegesis, becoming authentic representative of the Brazilian political class, presented in narrative film, as corrupt and oblivious to the public interest.

\section{Key words}

Media character; figuration; narrative; politics. 
(Página deixada propositadamente em branco.) 


\title{
Aletheia Patrice Rodrigues Vieira e Liziane Soares Guazina, De berói a anti-berói: a caracterização da personagem José Dirceu na revista Veja
}

\begin{abstract}
Resumo
O artigo analisa a caracterização do ex-ministro da Casa Civil José Dirceu como personagem jornalística em quatro reportagens da revista Veja nos anos de 1968, 2002 e 2005, que relatam diferentes momentos da trajetória de Dirceu como figura pública. Por meio de fundamentos da análise crítica da narrativa, o estudo se concentra em revelar quais as adjetivações e funções atribuídas a José Dirceu nos textos jornalísticos, delineando um ciclo da personagem baseado no Ciclo do Herói de Campbell (1969) e na saga anti-heroica proposta por Motta (2011). Veja reúne caracterizações que apresentam José Dirceu como personagem contraditório e destaca atitudes do ex-ministro que considera negativas, um dos elementos que compõe a construção de um anti-herói.
\end{abstract}

\section{Palavras-chave}

Personagem jornalística; José Dirceu; revista Veja; anti-herói.

\section{From hero to anti-hero: the composition of José Dirceu's character in Veja magazine}

\begin{abstract}
This paper analyzes the characterization of the former minister of Staff José Dirceu as journalistic character in four journal articles See in the years 1968, 2002 and 2005, reporting different times of Dirceu's career as a public figure. Through foundations of the critical narrative analysis, the study focuses on reveal which adjectives and functions are attributed to José Dirceu in journalistic texts, outlining a character cycle based on
\end{abstract}


Campbell's Hero Cycle (1969) and anti-saga heroic proposed by Motta (2011). See gathers characterizations presenting José Dirceu as contradictory character and highlights former minister of attitudes that considers negative, one of the elements that make up the construction of an anti-hero.

\section{Keywords}

Journalistic character; Jose Dirceu; Veja magazine; antihero. 


\section{Célia Maria Ladeira Mota e Leylianne Alves Vieira, Caminbos nar- rativos: um personagem: o brasileiro}

\section{Resumo}

Neste artigo, analisamos a caracterização de um personagem como é concebida em dois gêneros narrativos: o ficcional e o jornalístico. Vamos observar como o brasileiro é representado em Macunaíma, na obra de Mário de Andrade, e na reportagem da revista Realidade "O canavial esmaga o homem", que conta a saga de Gregório, um trabalhador de engenho. O foco é perceber as subjetividades dos relatos e os contrastes entre a fantasia e a realidade e compreender os significados construídos. São representações da identidade do brasileiro que têm sua origem em duas matrizes culturais que herdamos dos portugueses: a aventura e o trabalho.

O caminho teórico é o da Análise Crítica da Narrativa, como proposta por Motta, para quem "esta análise é um caminho rumo ao significado e o significado é uma relação: não há significado sem algum tipo de troca" (Motta, 2013: 121). Investigando as jornadas dos dois personagens e os acontecimentos nos quais se envolvem, de acordo com o ciclo do herói proposto por Campbell (2007), a análise estuda os significados que emergem de práticas culturais que têm raízes históricas e que até hoje contribuem para certa ambiguidade na concepção da identidade do brasileiro. A primeira narrativa analisada é ficcional e trata de um personagem que foi concebido nos primeiros anos do século $\mathrm{XX}$, quando começa a se forjar a ideologia de um Brasil fruto de uma mestiçagem de três raças. Macunaíma, de Mário de Andrade, conta a história entre fábula e mito de um personagem que vai ser objeto de uma inclusão cultural precoce para a época, um retrato de um brasileiro aventureiro que mistura qualidades e defeitos. A segunda narrativa é o relato jornalístico de um personagem real, Gregório, um plantador de cana de açúcar. A reportagem foi publicada na revista Realidade, na década de 1970, e mostra as condições de vida do personagem, que ainda podem ser encontradas em dias mais recentes. 
Não há milagres na história dele, um brasileiro como tantos outros lutando para sobreviver em condições precárias.

Na análise, os dois personagens são examinados a partir de uma perspetiva de identidade e de construção de brasilidade de cada um deles, levando em conta os cenários diferentes. O objetivo foi observar a dicotomia da identidade do brasileiro que tem base em dois princípios que se opõem desde os tempos coloniais. Macunaíma revela um jeito de ser e de sobreviver que caracteriza o brasileiro, "o jeitinho", a malandragem. Gregório, por sua vez, não acredita em milagres, mas na sobrevivência pelo trabalho. Sérgio Buarque de Holanda (1988) no livro Raizes do Brasil, afirma que esses dois princípios, aventura e trabalho, regularam diversamente as atividades dos portugueses que participaram da grande aventura de posse das terras brasileiras no período colonial.

\title{
Palavras chave
}

Narrativa; personagem; identidade; cultura.

\section{Narrative patbs a character: the Brazilian}

\begin{abstract}
In this article, we analyze the characteristics of a character as conceived in two narrative genres: the fictional and the journalistic. We researched how the Brazilian identity is represented in Macunaima, the work of Mario de Andrade, and in the Reality magazine report The sugarcane crushing the man, who tells the story of Gregory, a sugarcane worker. The focus is to perceive the subjectivities of the reports and the contrasts between fantasy and reality, looking for understanding the meanings constructed. They are representations of Brazilian identity that has its origin in two cultural matrixes that we inherited from the Portuguese: the adventure and the work. The theoretical framework is Critical Narrative Analysis, as proposed by Motta, for whom «this analysis is a path to the meaning and significance
\end{abstract}


as a relationship: there is no meaning without some kind of exchange» (MOTTA , 2013:121). Investigating the journeys of the two characters and the events in which they were engaged, according to the cycle of the hero proposed by Campbell (2007), the analysis studies the meanings that emerge from cultural practices that have historical roots and that even today contribute to the ambiguity for Brazilian identity.

The first analyzed narrative is fictional and is a character that was designed in the early years of the twentieth century, when it was begun to shape the ideology of Brazil as a result of a crossbreeding of three races. Macunaima, by Mário de Andrade, tells the story of fable and myth of a character that had been subject to an early cultural inclusion for the time, a picture of an adventurous Brazilian blending qualities and defects. The second narrative is the journalistic account of a real character, Gregory, a worker of sugar cane. The report was published in the magazine Reality, in the 1970s, and shows the living conditions of the character, which can still be found in recent days. There are no miracles in his story, a Brazilian like so many struggling to survive in precarious conditions.

In the analysis, the two characters are examined from the perspective of identity and Brazilianness construction of each of them, taking into account the different scenarios. The objective was to observe the dichotomy of Brazilian identity that is based on two principles that have been opposed since colonial times. Macunaima reveals a way of being and survival that characterizes the Brazilian, "the jeitinho", the trickery. Gregory, in turn, does not believe in miracles, but works for survival. Sérgio Buarque de Holanda (1988) in the book Roots of Brazil, says that these two principles, adventure and work, regulated the activities of the Portuguese who participated in the great adventure of taking possession of Brazilian lands in the colonial period.

\section{Key words}

Narrative; character; identity; culture. 
(Página deixada propositadamente em branco.) 


\section{João Canavilhas et. al., Era pós-PC: a nova tessitura da narrativa jornalística na web}

\section{Resumo}

A integração dos dispositivos móveis nas práticas jornalísticas acrescentou novas possibilidades à narrativa do webjornalismo, abrindo caminho para experiências inovadoras. Ao analisar um conjunto de produtos jornalísticos na web, este capítulo lança um olhar sobre um novo ecossistema mediático estimulado pela inserção de tecnologias móveis nos processos de produção, distribuição e consumo de notícias. O trabalho defende que estas tecnologias ubíquas reconfiguram a "tessitura da narrativa" ao criarem novos mecanismos para a estruturação dos elementos multimédia, com consequências decisivas na forma como os utilizadores interagem com os conteúdos. Recorrendo a uma perspetiva histórica, o objetivo central deste trabalho é debater o atual webjornalismo, tendo como referência as potencialidades da hipernarrativa associada aos dispositivos móveis. A análise concentra-se em cinco conceitos fundamentais nesta modalidade discursiva: bases de dados, contextualização, imersão, continuum multimédia e paralaxe/verticalização.

\section{Palavras-chave}

Dispositivos móveis; Hipernarrativa; Ecossistema mediático; Convergência jornalística. 
The post-PC era: the new of narrative on the web fabric

\begin{abstract}
The presence of mobile devices in the journalistic practice has added new possibilities to the web journalism's narrative, opening the way for innovative experimentations. By analyzing a relevant set of outstanding products within the digital environment, this article looks at a new media ecosystem stimulated by the insertion of mobile technologies in the processes of producing, distributing and consuming news. The research argues that these ubiquitous technologies reconfigure the efabric of the narrative" as they create new mechanisms that structure multimedia elements, with decisive consequences for how users interact with those contents. Through an historical outlook, the main objective is to discuss the current stage of web journalism using hypernarrative capabilities associated with mobile devices. The analysis focuses on five fundamental elements used in this discursive mode: database, contextualization, immersion, multimedia continuum, parallax/verticalization
\end{abstract}

\title{
Key words
}

Mobile Devices; Hypernarrative; Media ecosystem; Journalistic convergence. 
Daniela Maduro, Entre textões e escritões: a narrativa projetada

\section{Resumo}

Dada a possibilidade de comunicação e publicação instantâneas, o papel do leitor pode ser hoje facilmente substituído pelo papel do autor. No caso da literatura eletrónica, esta transferência de papéis tem vindo a ser intensamente explorada através da ampliação das funções do leitor. A interatividade, porque exige que o leitor permaneça concentrado na montagem e exploração do texto, é frequentemente considerada como um obstáculo à produção de uma narrativa. Esta é vista como dependente de uma sequência coerente de eventos pautada por um desfecho. Porém, os textos interativos, frequentemente focados na exploração da multilinearidade e aleatoriedade, parecem contrariar essa noção de narrativa. Neste artigo, pretendo referir-me ao impacto do meio digital nas noções de "leitor", "autor" e "texto" e explorar a possibilidade de o leitor encontrar uma narrativa projetada entre textões e escritões. Para tal, analisarei obras fundamentalmente interativas, que exigem que o leitor assuma diferentes funções para ler e compreender o texto.

\section{Palavras-Chave}

Narrativa; esforço ergódico; esforço imaginativo; interatividade; La Disparue; The Stanley Parable. 
Between textons and scriptons: the projected narrative

\begin{abstract}
Due to the possibility of instantaneous communication and publication, the role of the reader and the role of the author can be easily interchanged. In the case of electronic literature, this transference has been widely explored through an extension of reader's functions. Interactivity, because it demands a focus on the assemblage and exploration of the text, is frequently considered as an obstacle to the production of a narrative. This happens because narrative is often seen as dependent on a coherent sequence of events in line with a closure. Interactive texts, which often explore randomness and multilinearity, seem to undermine this notion of narrative. Throughout this article, I intend to analyze how new media have impacted our notions of "reader", "author", and "text" and explore the possibility of coming across a projected narrative somehow located between textons and scriptons. In order to do that, I will analyze works which are fundamentally interactive and demand the reader to undertake several functions in order to read and understand a text.
\end{abstract}

\title{
Key words
}

Narrative; ergodic effort; imaginative effort; interactivity; La Disparue; The Stanley Parable. 


\section{Fernanda Castilho Santana, Narrativas em mudança: do folbetim aos textos transmedia}

\section{Resumo}

Ao refletir sobre os processos comunicativos estabelecidos na atualidade, a partir dos diferentes conceitos que permeiam esse momento histórico de profundas alterações tecnológicas e culturais, passamos a compreender que a dimensão tomada pelos novos meios, nesse contexto paradigmático, modifica tanto a forma, como o conteúdo das mensagens. Relativamente às histórias ficcionais que utilizam a televisão como suporte expressivo, a crescente migração das audiências para a assistência noutras plataformas resulta, sobretudo, na alteração do relacionamento entre texto e leitor. Na tentativa de compreender os caminhos traçados pelas narrativas ficcionais nesse contexto de mudanças sócio-tecno-culturais, a necessidade de recorrer à literatura dedicada ao estudo das histórias materializadas em diferentes suportes expressivos tornou-se clara no decorrer do presente trabalho. Por outro lado, ao atentar para os estudos que oferecem uma perspetiva histórica sobre as narrativas de ficção, identificamos elementos que aproximam e distinguem a produção desses conteúdos ao longo dos séculos. Desta forma, a proposta deste artigo assenta numa reflexão teórica sobre as mudanças no campo das narrativas televisivas de ficção, considerando o papel dos novos suportes expressivos para a criação de narrativas transmediáticas.

\section{Palavras-chave}

Narrativas ficcionais; Televisão; Transmedia Storytelling; Novas Tecnologias. 


\title{
Narratives changing: from serial to transmedia texts
}

\begin{abstract}
Reflecting on the communicative processes currently established, from the different concepts that permeate this historical moment of depth technological and cultural change, we understand that the dimension taken by the new media, in this paradigmatic context, modifies both the form and the message contents. In the fictional stories that use the television as expressive support, the increasing migration of audiences to other platforms results mainly in the changing of the relationship between text and reader. In order to understand the fictional narratives trajectory, in this context of socio-techno-cultural changes, the necessity to call upon proper literature about the study of stories materialized in different expressive media has become clear in the course of this work. On the other hand, paying attention to the studies that offer a historical perspective of the fictional narratives we identified elements the approach and distinguish the production of this content over the centuries. Thus, the aim of this article is a theoretical reflection about the changes in the field of television narrative fiction, considering the role of new expressive media supplies for creating transmedia narratives.
\end{abstract}

\section{Key words}

Fictional Narratives; TV; Transmedia Storytelling; New Technologies. 
(Página deixada propositadamente em branco.) 
(Página deixada propositadamente em branco.) 
Ana Teresa Peixinho nasceu em Coimbra em 1971. É doutorada pela Universidade de Coimbra em Ciências da Comunicação e é Professora Auxiliar da Faculdade de Letras da mesma Universidade. Investigadora do Centro de Estudos Interdisciplinares do Século XX (CEIS20) e do Centro de Literatura Portuguesa (CLP), tem-se dedicado aos estudos queirosianos, no âmbito dos quais integra o projeto de Edição Crítica da obra de Eça de Queirós. Também integra o grupo de trabalho do projeto Figuras da Ficção, coordenado por Carlos Reis, onde tem desenvolvido investigação sobre narrativas e personagem.

Bruno Araújo é doutorando do Programa de Pós-Graduação em Comunicação e Sociedade da Universidade de Brasília.

Mestre e licenciado em Comunicação e Jornalismo pela Universidade de Coimbra, onde defendeu a dissertação "Media, Justiça e Espaço Público: a cobertura jornalística do julgamento do mensalão em Veja e Época". É investigador do Núcleo de Estudos em Mídia e Política e do Grupo de Pesquisa Cultura, Mídia e Política, ambos da Universidade de Brasília.

É membro colaborador do Centro de Estudos Interdisciplinares do Século XX da Universidade de Coimbra. 
Série Investigação

Imprensa da Universidade de Coimbra

Coimbra University Press

2017

- U

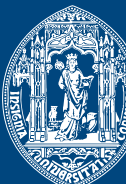

C .

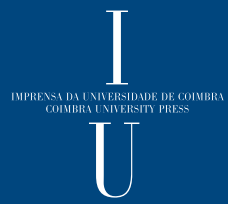

